UNIVERSIDADE DE SÃO PAULO

FACULDADE DE FILOSOFIA, CIÊNCIAS E LETRAS DE RIBEIRÃO PRETO PROGRAMA DE PÓS-GRADUAÇÃO EM EDUCAÇÃO

MICHEL LUÍS DA CRUZ RAMOS LEANDRO

Autoria e Resistência: Carolina Maria de Jesus em discurso

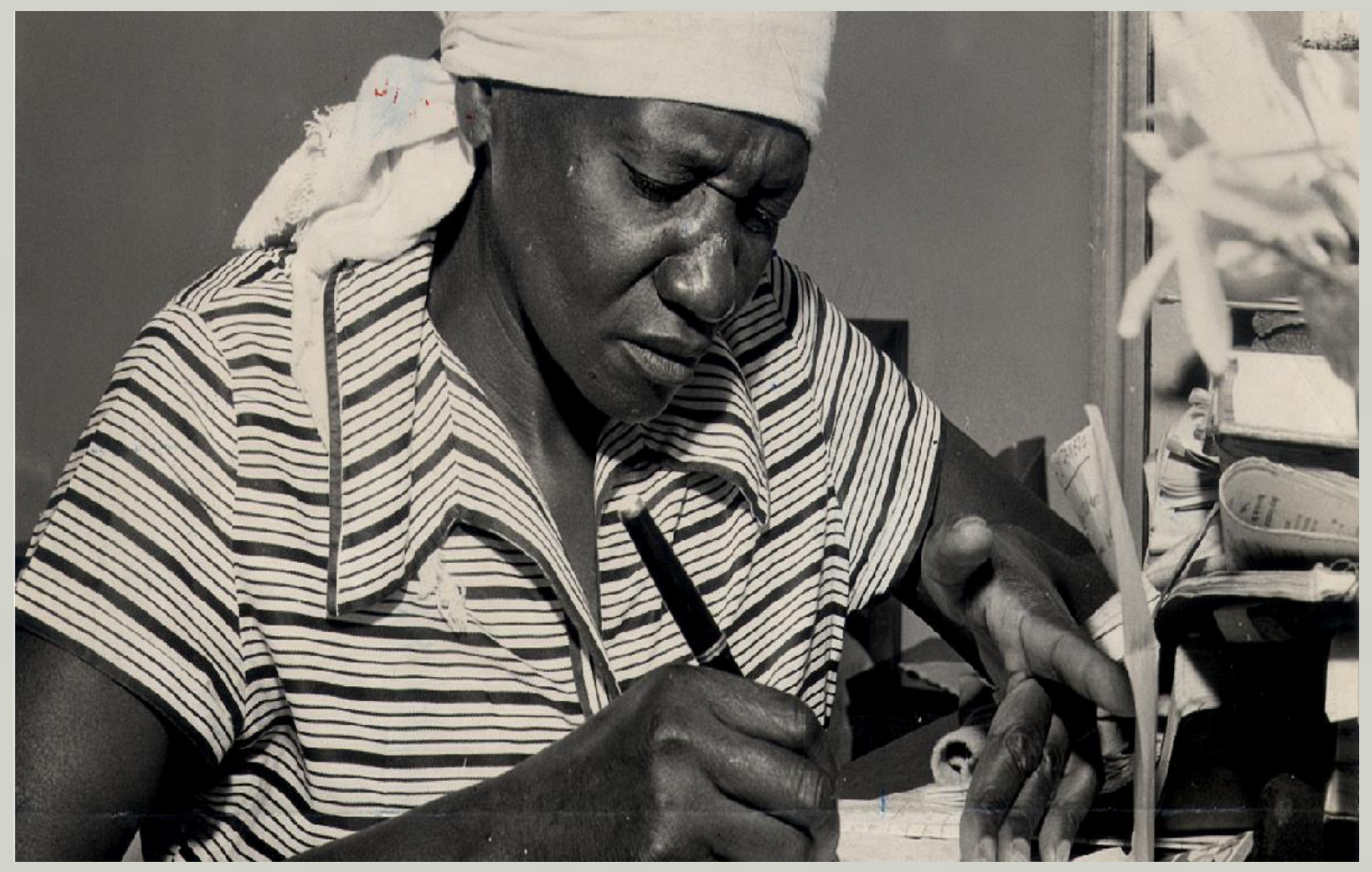

Ribeirão Preto, SP 


\section{Autoria e Resistência: Carolina Maria de Jesus em discurso}

\section{Versão Corrigida}

Dissertação de Mestrado apresentada ao Programa de Pós-Graduação em Educação da Faculdade de Filosofia, Ciências e Letras de Ribeirão Preto, da Universidade de São Paulo, para obtenção do título de Mestre em Educação.

Área de Concentração: Educação

Orientadora: Profa. Dra. Soraya Maria Romano Pacífico

Ribeirão Preto, SP 
Autorizo a reprodução e divulgação total ou parcial deste trabalho, por qualquer meio convencional ou eletrônico, para fins de estudo e pesquisa, desde que citada a fonte.

Leandro, Michel Luís da Cruz Ramos

Autoria e Resistência: Carolina Maria de Jesus em discurso.

Ribeirão Preto, 2019.

184 p. : il. ; $30 \mathrm{~cm}$

Dissertação de Mestrado, apresentada ao Departamento de Educação, Informação e Comunicação, da Faculdade de Filosofia, Ciências e Letras de Ribeirão Preto/USP. Área de concentração: Educação

Orientador: Pacífico, Soraya Maria Romano

1. Escrita. 2. Discurso. 3. Sujeito-autor. 4. Resistência. 
Dedico esta dissertação à:

Elizandra Souza e Carmem Faustino, mulheres, negras, periféricas, por terem me apresentado Carolina Maria de Jesus, em uma oficina intitulada Literatura Feminina Negra, ocorrida no SESC Ribeirão Preto - SP, ainda mais, por também levarem o direito à literatura de autoria de mulheres negras para dentro e fora do país, sobretudo, pela referência e resistência de negritude.

Ao Sarau das Pretas: Débora Garcia, Elizandra Souza, Jô Freitas, Taissol Ziggy e Thata Alves, por me ensinarem sobre a palavra-preta.

Por fim, para todas as mulheres negras do país aqui não citadas, como disse Elizandra Souza "Ser cabaça, ser fértil/ simples, discretal suave, dura e impermeável/ Reverberar o som com suas sementes", sim, às Anas, Carolinas, Conceições, Elisas, Lélias, Marielles, Suelis, tantas outras. 
Agradecimentos especiais à minha orientadora Soraya Maria Romano Pacífico por ter aceitado essa empreitada comigo uma pesquisa acadêmica sobre literatura de autoria de mulheres negras -, mais ainda, por ser inspiração e referência de caráter e amor, tanto na esfera pessoal, quanto na acadêmica. Por acreditar em mim quando não mais acredito. Por ouvir antes de falar. Por apontar o que precisa ser melhorado com doçura. Pela sabedoria! Por ensinar que a trajetória acadêmica tem de ser leve e acalmar o meu medo. Por lutar pela educação deste país. Você é única!

Ao Everton Luiz dos Reis Franscico, o meu Tom Reis, por ensinar-me tanto sobre negritude. Pela paciência! Por estar ao meu lado em todos os momentos desta jornada acadêmica. Por ser o meu melhor amigo e amor. Porque é bom te amar todos os dias e em todas as horas!

Às minhas mães, Dirce Ramos e Érica Leandro, que são a minha base: o começo, o centro e o fim. O amor sem limites. Por terem, muitas vezes, deixado os seus sonhos para lutarem pelos meus. Por me ensinarem a ter garra e a confiar em mim. 


\section{AGRADECIMENTOS}

Ao pensar em como iniciar os agradecimentos, antes, respiro fundo, fecho os olhos, coloco os fones de ouvidos e, ao som de Ain't got no, i got life, Nina Simone, recordo do adolescente que fui: rodeado por livros, gizes, cadernos, canetas, cds e uma lousa grande que me foi dada de presente pelo meu saudoso padrinho, Aparecido. Ele tinha me levado a uma loja de brinquedos. Chegando lá, rodiei, rodiei e rodiei as prateleiras, pois não queria carrinhos ou os brinquedos que eram considerados de "menino", o meu desejo era pela lousa gigante que tinha naquela loja. Então, foi quando ele disse: "Fique com a lousa!".

Eu adorava brincar de escolinha! De ler! De preencher (ou agregar), principalmente, a minha solidão com a literatura e a música. De escrever. Foram muitos dias e horas em que passei as minhas tardes e noites isolado da família para "brincar de ser professor". Eu adorava subir em árvores para ficar ouvindo o vento e as pessoas lá de cima. Ou ficar no quarto escuro escutando minhas músicas preferidas.

É por isso que começo os agradecimentos citando a minha família: minhas mães, Érica Leandro, genitora, Dirce Ramos, avó materna de criação. Aos meus tios (por conta da criação os vejo como irmãos), Jorge Ramos e Júlio Ramos. Aos meus irmãos Bruce Leandro, Dirce Leandro e Vitória Leandro. Aos meus pais, Lázaro Leandro (que me assumiu e me deu seu nome de família), e Donizeti Ramos (avô materno de criação). Por terem ao longo do tempo aceitado o meu jeito de ser e as minhas escolhas, sejam elas quais forem. Porque são a base! Ninho. Colo. Segurança. Proteção. Por aceitarem as minhas esquisitises e isolamentos. Sobretudo, porque sabem mais de mim do que eu mesmo. Por sermos tão diferentes, mas também tão iguais, em um paradoxo sem fim recheado de amor.

Pois bem, voltando ao assunto de brincar de escolinha e com as "minhas solidões", quando cheguei ao Ensino Médio, ouvi o professor de Química, Antônio Eduardo Miller Crotti, comentar sobre o seu mestrado e doutorado na USP e toda sua saga: dificuldades e prazeres. Ele falou sobre o direito que nós, estudantes, também tínhamos de chegarmos lá. Apresentou-me o filme Sociedade dos Poetas Mortos e disse que uma das personagens se parecia comigo. Outra pessoa especial é a professora Rosimeire Arantes, de Língua Portuguesa, que encapava os livros com temáticas LGBTS para me emprestar, mostrando-me que a minha orientação sexual nunca poderia me diminuir como humano e, sim, que era um direito eu ser quem sempre fui. Pense um discurso desse para um sujeito-adolescente? É pela imagem desses dois professores que agradeço a todas (os) professoras (es) que tive na 
Educação Básica, pois são a primeira base da minha formação.

O professor Antônio, dentre outros, ao dizer que a universidade pública é um lugar feito para nós, alunos de periferia e de escola pública, ocuparmos, fez com que eu desejasse chegar lá: acessar um programa de pós-graduação srictu senso. Eu considerava tão especial alguém conseguir tornar-se mestre e/ou doutor. Depois, achei mais especial ainda quando olhava o nome de algum professor antecedido pelo título de mestre ou doutor em uma apresentação de power point. Eu sempre soube que, para chegar lá era preciso muito estudo, dedicação, disciplina e responsabilidade com o saber. E o saber é sempre dolo/pode/praze(roso)! Ainda mais para um pesquisador que decide (re)mexer com questões tão caras, como é o caso da literatura de autoria de mulheres negras. O meu compromisso com o que é deixado de fora na academia tem sido meu lema como pesquisador.

Mas antes de chegar lá, precisaria começar pela graduação. Foram duas formações, licenciaturas em Letras e Pedagogia, a primeira, em uma faculdade particular, Faculdade de Filosofia, Ciências e Letras de Ituverava, por meio do Prouni, importantíssimo programa que possibilitou que eu realizasse o sonho de adentrar o Ensino Superior. A segunda, na Faculdade de Filosofia, Ciências e Letras de Ribeirão Preto - Universidade de São Paulo - em que ainda sou capaz de lembrar da emoção de ver meu nome aprovado no curso de Pedagogia.

Nas Letras, preciso agradecer a todas as professoras que tive, Erika Luiza Pizza, orientadora do meu primeiro trabalho de conclusão de curso sobre a literatura da Clarice Lispector; Lisângela Guiraldelli (pela honestidade e competência docente); Maria do Carmo R. Barbosa (D. Carminha, por ser a professora mais generosa que já conheci, uma freiana nata); Sara Jorge (D. Sarinha, com quem passei muitas noites em sua casa para que eu pudesse participar de um programa de iniciação científica); Sueli Gorricho (professora de Literatura Brasileira que fazia eu ler os poemas para a sala, pois dizia que lia com emoção); e Fabiana Borges (hoje, amiga pessoal e bússola). Aliás, Fabiana Borges convida Soraya Pacífico para proferir uma palestra na semana de Letras. Esse evento acabou por mudar a minha vida, pois foi nele que conheci a minha orientadora. Naquele dia pensei: Um dia ainda serei orientando dessa professora!, dito e feito.

$\mathrm{Na}$ Pedagogia, também preciso agradecer a todas (os) professoras (es), em especial, os que sempre estiveram e/ou estão mais perto da minha trajetória atual: Ana Lodi (por ter me apresentado a obra Pedagogia da Tolerância, do Paulo Freire); Bianca Correa (por ser referência na Educação Infantil); Débora Piotto (por dialogar com a minha pesquisa); Elaine Araújo (pela sabedoria); Elmir de Almeida (idoneidade de seu posicionamento); Francirosy Barbosa (carinhosa e atenciosa); Noeli Rivas (pelo comprometimento com a formação do 
professor); e a minha orientadora Soraya Pacífico (referêcia e base de tudo até aqui). A graduação em Pedagogia foi um "divisor de águas", porque passei a ser, além de professor de Língua Portuguesa, Educador - Pedagogo - e tenho orgulho disso.

Eu consegui chegar ao programa de pós-graduação porque antes, todas essas pessoas já citadas, fizeram com que o meu camimho fosse mais leve e especial.

Agradeço ao Programa de Pós-Graduação em Educação, do DEDIC/FFCLRP-USP, pela luta por uma escola pública de qualidade e o esforço de construir uma formação coerente e comprometida com uma educação democrática e emancipadora.

Agradeço à Lucília Maria Abrahão e Sousa, pela referência que é para mim na poesia e Análise de Discurso, pela receptividade com que sempre me recebeu em seu círculo acadêmico e por trazer um olhar tão lúcido para esta pesquisa. E a Nildiceia Aparecida Rocha, que também participou da qualificação e apontou direcionamentos tão importantes, com comentários tão generosos, iluminando ainda mais esta dissertação.

Não poderia deixar de agradecer essas mulheres que me rodeiam e constituem o feminino que há em mim, seja pelas nossas discussões calorosas acadêmicas, seja pela amizade que ultrapassa a academia: Ana Paula Alberto Lopes (Ana P.), Ana Rubia da Silva, Elen Cristina Nascimento Coelho, Maria Aparecida de Souza Carvalho (Lia), Noilma Alves Martins, Rita de Cássia Constantini Teixeira, Thaís Silva Marinheiro de Paula e Valéria Fernandes Turci.

Também faço questão de agradecer a todas as pesquisadoras e pesquisadores que são citados nesta dissertação, pois, sem o trabalho sério, honesto, competente, responsável, comprometido desses sujeitos, não haveria possibilidade de esta dissertação ser escrita com tantos diálogos e referências importantes. O pesquisador em formação não se constitui sem os que vieram antes dele, seja para confirmar ou refutar a produção de conhecimento desses autores.

Então, chego ao fim dos agradecimentos com a sensação de que falta citar ainda mais vozes. E sei que sempre falatará! Nenhum sucesso que tive até hoje foi sem a ajuda de alguém, como já disse, sou afortunado de pessoas lindas, iluminadas e companheiras que, cada uma a seu modo, contribuíram para que eu chegasse aqui.

Agora estou ouvindo pela décima vez a música da Nina Simone, escuto os versos finais: I've got lifel I've got my freedom, decido trocar a música, coloco Elza Soares, a canção $A$ mulher do fim do mundo e termino esse texto com os versos cantados por ela: Até o fim eu vou cantar/ Eu quero cantar/ Me deixem cantar até o fim/ La la la laia la la laia/. Vozez de mulheres negras que me constituem e ensinam tanto, principalmente, sobre resistência! 
E o meu desejo é este: que esta dissertação possa incomodar, cantar, entoar, mais uma vez, a voz poderosa de Carolina Maria de Jesus, diria, das Carolinas desse país. Sobretudo, que o canto deste trabalho acadêmico possa chegar às escolas e aos cursos de licenciatura, porque é ali, nesses espaços, que consigo vislumbrar uma fresta de luz e transformação do status quo, em que as literaturas marginalizadas possam "feder", isto é, estarem presentes nesses lugares, a começar, no currículo da escola, na sala de aula e nas ementas universitárias, como disse Milton Nascimento, na canção Maria Maria, é essa "estranha mania de ter fé na vida”. E eu tenho! 
Não vou mais lavar os pratos

Não vou mais lavar os pratos

Nem vou limpar a poeira dos móveis

Sinto muito. Comecei a ler.

Abri outro dia um livro e uma semana depois decidi

Não levo mais o lixo para a lixeira.

Nem arrumo a bagunça das folhas que caem no quintal

Sinto muito. Depois de ler percebi a estética dos pratos, a estética dos traços, a ética,

A estática

Olho minhas mãos quando mudam a página dos livros, mãos bem mais macias que antes,

E sinto que posso começar a ser a todo instante.

Qualquer coisa

Não vou mais lavar. Nem levar.

Seus tapetes para lavar a seco.

Tenho os olhos rasos d'água

Sinto muito.

Agora que comecei a ler, quero entender

O porquê, por quê?? E o porquê

Existem coisas. Eu li, e li, e li. Eu até sorri

E deixei o feijão queimar...

Olha que ofeijão sempre demora a ficar pronto

Considere que os tempos agora são outros...

Ah,

Esqueci de dizer. Não vou mais

Resolvi ficar um tempo comigo

Resolvi ler sobre o que se passa conosco

Você nem me espere. Você nem me chame. Não vou

De tudo o que jamais li, de tudo o que jamais entendi, 
Você foi o que passou

Passou do limite, passou da medida, passou do alfabeto.

Desalfabetizou

Não vou mais lavar as coisas e encobrir a verdadeira sujeira

Nem limpar a poeira e espalhar o pó daqui para lá e de lá para cá

Desinfetarei as minhas mãos e não tocarei suas partes moveis

Não tocarei no álcool

Depois de tantos anos alfabetizada, aprendi a ler Depois de tanto tempo juntos, aprendi a separar Meu tênis do seu sapato,

Minha gaveta das suas gravatas

Meu perfume do seu cheiro

Minha tela da sua moldura

Sendo assim, não lavo mais nada,

e olho a sujeira no fundo do copo.

Sempre chega o momento

De sacudir, de investir, de traduzir

Não lavo mais pratos

Li a assinatura da minha lei áurea escrita em negro maiúsculo,

Em letras tamanho 18, espaço duplo.

Aboli

Não lavo mais os pratos

Quero travessas de prata, cozinhas de luxo

E joias de ouro.

Legítimas

Está decretada a lei áurea. 
(SOBRAL, 2011, p. 23).

\section{RESUMO}

\section{LEANDRO, Michel Luís da Cruz Ramos. Autoria e Resistência: Carolina Maria Jesus em} discurso. 2019. 184f. Dissertação (Mestrado em Educação) - Universidade de São Paulo, Faculdade de Filosofia, Ciências e Letras de Ribeirão Preto. 2019.

A partir dos fundamentos da Análise de Discurso francesa, construída por Michel Pêcheux, esta pesquisa objetivou investigar o modo como Carolina Maria de Jesus, na posição de sujeito-autor, por meio da sua primeira obra, Quarto de Despejo: diário de uma favelada (2014), publicada em 1960, e também da obra, Diário de Bitita (2016), relacionou-se com a escrita e se constitui autor de literatura. Especificamente, buscou-se investigar, nas marcas de autoria desse sujeito, os efeitos de sentidos de resistência que fazem com que essa produção literária possa ser reconhecida como literatura de enfrentamento social, que joga o jogo da política literária, contribuindo, por fim, para a reflexão da ausência de autoras negras na escola e em outras instituições, apontando, portanto, alguns questionamentos acerca desse silenciamento. Para isso, foram selecionados recortes que pudessem trazer marcas linguísticas da relação do sujeito-autor com a escrita, de modo que fosse possível analisar o processo de autoria desse autor pela via da resistência. As análises apontam que a escrita de Carolina Maria de Jesus é um ato de resistência porque rompe com uma formação imaginária de autor (branco, classe média, com alto grau de escolaridade, intelectual), assim como faz ranger a política literária que funciona canonizando determinadas autoras e autores e suas obras e interditando outros. O sujeito-autor ao discursivizar sobre a fome da escrita e a escrita da fome pela tessitura do poético, provoca a formação de uma literatura de enfrentamento social. Além do mais, ao materializar sentidos sobre a escola em sua obra e também trabalhar uma literatura-filósofica, por meio de uma escrita-indagadora, esse sujeito-autor trabalha o interdiscurso no intradiscurso a fim de construir o seu projeto artístico literário, trazendo outras geografias literárias a partir do seu não-lugar na historiografia da literatura brasileira.

Palavras-chave: Escrita; Discurso; Sujeito-autor; Resistência. 


\begin{abstract}
LEANDRO, Michel Luís da Cruz Ramos. Authorship and Resistance: Carolina Maria Jesus in discourse. 2019. 184f. Dissertation (Master's degree) - University of de São Paulo, Philosophy, Sciences and Letters of Ribeirão Preto. 2019.

From the foundations of the French Discourse Analysis, built by Michel Pêcheux, this research aimed to investigate the way Carolina Maria de Jesus, in the position of subject-toauthor, through her first work, Room of Eviction: diary of a favelada (2014), published in 1960, and also of the work, Diário de Bitita (2016), was related to writing and is the author of literature. Specifically, we sought to investigate, in the authorship marks of this subject, the effects of senses of resistance that make this literary production can be recognized as social coping literature, which plays the game of literary politics, Finally, contributing to the reflection of the absence of black authors in school and other institutions, pointing out, therefore, some questions about this silencing. For this, we selected clippings that could bring linguistic marks of the subject-author's relationship with writing, so that it was possible to analyze the author's process of authorship through resistance. The analyzes point out that the writing of Carolina Maria de Jesus is an act of resistance because it breaks with an imaginary formation of author (white, middle class, with a high level of education, intellectual), as well as creaks the literary politics that works. canonizing certain authors and their works and interdicting others. The subject-to-author to discursivize about the hunger of writing and the writing of hunger by the poetic textures, causes the formation of a literature of social coping. Moreover, by materializing meanings about the school in his work and also working a philosophical literature, by means of a research-writing, this subject-author works the interdiscourse in the intradiscourse in order to build his literary artistic project, bringing other literary geographies from their non-place in the historiography of Brazilian literature.
\end{abstract}

Key-words: Writing; Discourse; Subject-author; Resistance. 



\section{LISTA DE FIGURAS}

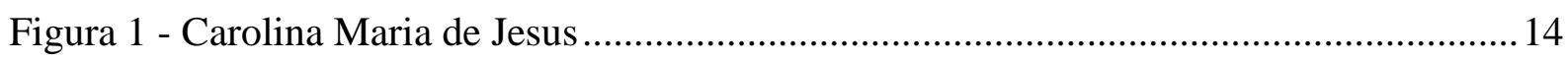

Figura 2 - Outdoor de divulgação "O diário de uma favelada" ..............................................22

Figura 3 - Conceição Evaristo subindo as escadas da ABL no dia da sua candidatura a uma das cadeiras.

Figura 4 - Relação dos livros mais vendidos do Jornal Folha de São Paulo, agosto de 1960,

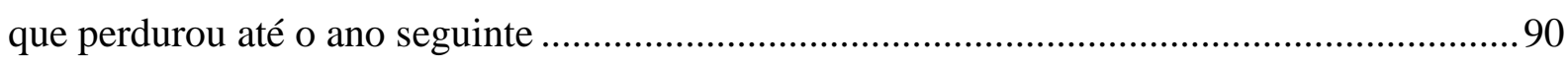

Figura 5 - Carolina Maria de Jesus, agora, "sofisticada" ...................................................... 91

Figura 6 - Carolina, cercada de crianças da favela de Canindé, muitas descalças, levadas ao lançamento numa Kombi patrocinada pelo jornal Última Hora, de São Paulo ........................ 92 Figura 7 - Carolina Maria de Jesus ao lado do ministro do trabalho, no dia do lançamento do seu livro ...... . .92

Figura 8 - Uma das primeiras reportagens anunciado o livro de Carolina, saiu no jornal Última

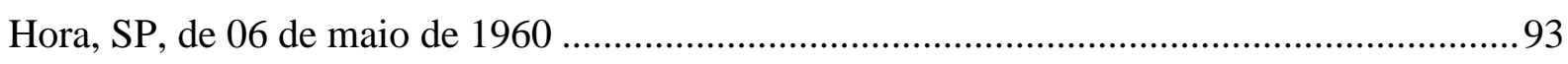

Figura 9 - Anúncio publicado no Correio Paulistano, em 05 de junho de 1862 .................... 102

Figura 10 - Anúncio publicado no Diário de Pernambuco, em julho de 1866 ....................... 103

Figura 11 - Anúncio publicado no Correio Paulistano, em 01 de novembro de 1863 - SP...103

Figura 12 - Carolina Maria de Jesus dando início ao curso de viagens ao exterior ................106

Figura 13 - (In)conclusões - Babel, escultura em argila ................................................... 109

Figura 14 - Carolina autografando seu livro durante o I Festival do Rio, em 09 de novembro de 1960

Figura 15 - Vento frio, dentro. Vento frio, fora. Vento, frio dentro e fora. Vento frio lá fora, acrí-lico sobre tela 119

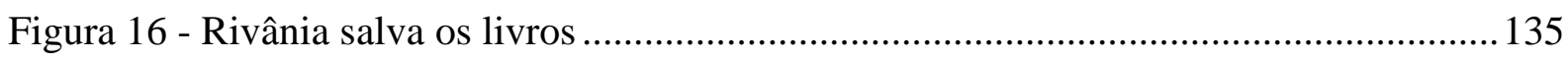

Figura 17 - Cinderela negra: a saga de Carolina Maria de Jesus........................................ 170

Figura 18 - Manuscrito de Carolina Maria de Jesus .............................................................. 175

Figura 19 - Google homenageia o centenário de Carolina Maria de Jesus ............................175 


\section{SUMÁRIO}

INTRODUÇÃO

1. POLÍTICA LITERÁRIA - NA TRAMA DA SALA DE AULA: UM AUTOR POUCO

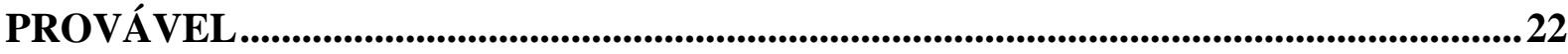

1.1. A estrutura social de poder racista e a sua influência na política literária ................32

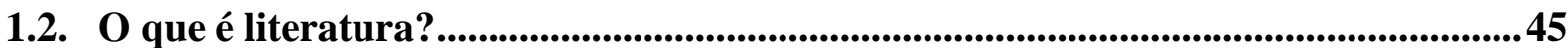

1.3. O que é um clássico da literatura?....................................................................................55

1.4. A questão do mercado editorial como voz que legitima, ou não, a autoria ...............68

1.5. Condições de produção que sustentam a construção de/em Carolina Maria de Jesus 78

1.6. Eis-me aqui: Carolina Maria de Jesus....................................................................................86

2. O TERRITÓRIO MOVENTE DAS PALAVRAS NA ANÁLISE DE DISCURSO: DISPOSITIVOS E PROCEDIMENTOS ANALÍTICOS ....................................................109

2.1. Sobre a constituição do corpus ............................................................................................. 115

3. AUTORIA E RESISTÊNCIA EM CAROLINA MARIA DE JESUS........................119

3.1. A "fome da escrita" e a "escrita da fome": o poético na/da favela.............................122

3.2. As formas de enfrentamento social e superação pela assunção da autoria ..............147

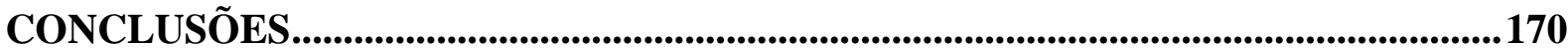

REFERÊNCIAS BIBLIOGRÁFICAS .......................................................................176 


\section{INTRODUÇÃO}

Figura 1 - Carolina Maria de Jesus

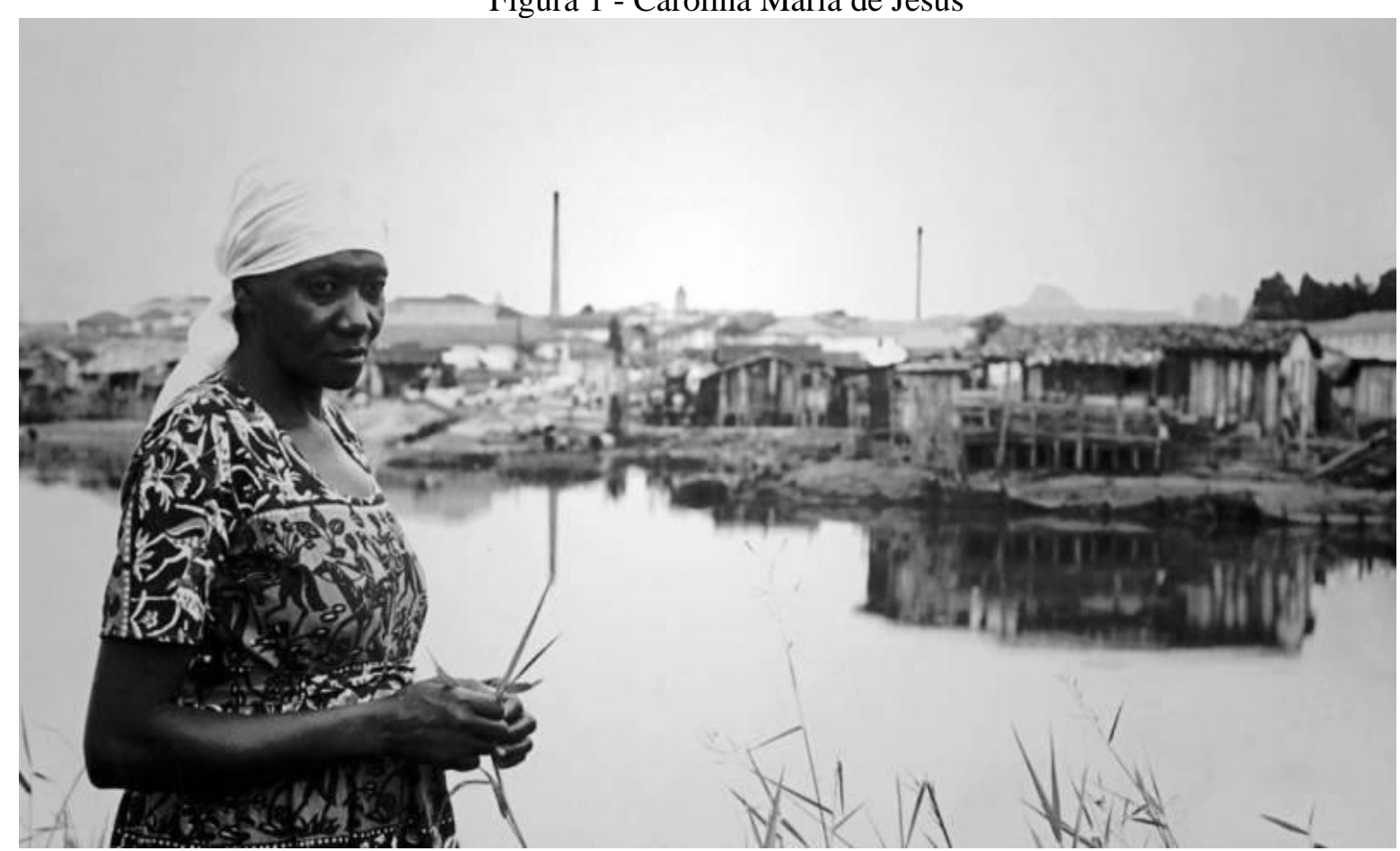

Fonte: Katty Illy (2018)

O livro... me fascina. Eu fui criada no mundo. Sem orientação materna. Mas os livros guiou os meus pensamentos. Evitando os abismos que encontramos na vida. Bendita as horas que passei lendo. Cheguei a conclusão que é o pobre quem deve ler. Porque o livro, é a bussola que ha de orientar o homem no porvir (...). (JESUS, 1996, p. 167). 
Esta dissertação de Mestrado trabalha a partir do referencial teório da Análise de Discurso pecheuxtiana, daqui em diante $\mathrm{AD}$, em articulação com alguns teórios de outras áreas de conhecimento. Pontos de encontros e diálogos que desencadeiam o cerne de discussão deste trabalho: que tipo de literatura importa, em especial, para a escola? Quem pode ser autor de literatura? Pode uma mulher negra ocupar a posição discursiva de autor?

Ao partimos de uma indagação fundamental: o tempo da escola proporciona espaço para o tempo da literatura? A resposta a essa pergunta - quando olhamos a escola de perto demonstra que vários fatores contribuem para que o tempo da literatura na escola seja um fracasso, a saber, a falta de formação continuada do professor, políticas educacionais neoliberais, currículo engessado e fragmentado, muitas vezes, por causa do livro didático, são algumas dessas razões que escamoteiam o trabalho de qualidade da literatura (e, também, de todas as áreas de conhecimento), por sua vez, da escrita e leitura, na escola.

É por isso que defendemos que ser professor (também pesquisador) é um ato político (FREIRE, 1999); nesse sentido, é importante que o professor tenha posicionamentos políticos, já que ao viabilizar a leitura da palavra, o educador leva o educando a ler o mundo, o que está ligado a mudanças políticas e sociais, pois, "não é o discurso que valida a prática, é a prática que dá vida ao discurso" (FREIRE, 2018, p. 41).

E ao pensar leitura, já é possível marcar que ler é ir além da paráfrase (o mesmo, a repetição), é trabalhar numa perspectiva polissêmica (o novo, o rompimento), tecendo sentidos e produzindo discursos, levando o sujeito-leitor a ocupar a função-leitor, capaz de realizar uma leitura interpretável (PACÍFICO, 2002), o que significa dizer que a nossa defesa é por uma escola "em que os educandos exercitem o direito de ser sujeitos" (FREIRE, 2018, p. 41) e o de ocuparem a posição discursiva de autores (PACÍFICO, 2016).

É a leitura que exige um posicionamento sócio-histórico, uma memória do dizer, visto que os textos são produzidos a partir de outros textos, já que é possível observar que esse lugar, por meio do discurso autoritário (ORLANDI, 2012), que cerceia o poder dizer do sujeito-aluno, corrobora para que a literatura constitua um corpo-textual estranho; portanto, não familiar a esses sujeitos (LEANDRO, 2016).

Uma das causas do estranhamento dos sujeitos-alunos em relação ao trabalho com a literatura na escola deve-se ao fato de o professor não ter um aparato teórico que sustente a sua prática. Isso faz com que o material didático, a voz da gestão escolar, entre outros, ocupe o lugar de autoria que deve ser do sujeito-professor que, por meio de um discurso imperativo, 
sanciona o modo como este profissional deve trabalhar em sala de aula. O resultado disso são sujeitos-professores e sujeitos-alunos que passam a compreender a literatura como um lugar fechado, cristalizado e de interdição.

Essa concepção de leitura fechada, única, sem furos, fundamenta-se na visão de transparência da linguagem, que pressupõe uma relação direta entre pensamento e linguagem, isto é, apoia-se nas teorias da comunicação e ciências positivistas, em que um emissor transmite a mensagem a um receptor que deve decodificá-la perfeitamente, ou seja, o sentido deve ser apenas um só. Nessa concepção, o sujeito é homogêneo, a exterioridade da linguagem não é considerada e a interpretação é cerceada, desconsiderando-a como um fato ideológico.

No entanto, por estarmos ancorados no referencial teórico da AD de "linha" francesa, concebemos a literatura como um campo de conhecimento humanizador que deve ser garantida na escola como um Direito Humano (CANDIDO, 1988); logo, a ideologia, a exterioridade e a história atravessam a relação do sujeito com a literatura.

Nesta direção teórica, compreende-se que todo texto é construído a partir de um já-dito - interdiscurso - que reclama do leitor uma memória do dizer (não a psicológica) que é sóciohistórica, portanto, discursiva. Desse modo, trabalhar a literatura na escola é ter que lidar com os espaços vazados do texto literário (BRAGATO FILHO, 1995), autorizando os sujeitosalunos a produzirem sentidos e discursos a respeito do que leem.

Para AD, o objeto de estudo é o próprio discurso, entendendo que a linguagem e a sua exterioridade são algo constitutivos, já que para esse referencial teórico a interpretação é uma questão ideológica, ligada à ideologia das instituições dominantes e, “(...) sendo a escola uma instituição, a interpretação deixa de ser um "ato de vontade própria" e continua ligada a uma classe que controla os sentidos que podem e devem ser lidos" (PACÍFICO, 2012, p. 17).

Como podemos notar, para a $\mathrm{AD}$, a ideologia está atrelada à interpretação, isso porque entendemos a ideologia como um mecanismo de naturalização dos sentidos, ou seja, certos sentidos, em dado contexto sócio-histórico, são autorizados e outros não de circularem socialmente, já que a ideologia estabelece o sentido único que homogeneíza a interpretação.

Nessa perspectiva teórica, o discurso é definido como o "efeito de sentidos entre locutores" (PÊCHEUX, 1969), e esses efeitos são construídos a partir de condições sóciohistórico-ideológicas que afetam os interlocutores do discurso. Isso indica que a AD não faz uma análise da língua, tal qual no estruturalismo saussuriano, que concebe a língua como 
estrutura, conforme lemos no Curso de Linguística Geral, de Ferdinand Saussure (1995), mas sim, do discurso (objeto sócio-histórico), sendo a língua a materialidade do discurso.

Esse modo como a teoria discursiva concebe o discurso, que "entende que as palavras não significam por si mesmas, mas sim, os sentidos das palavras dependem de sua inscrição na história" (PACÍFICO, 2012, p. 19), levaram-nos a querer compreender o modo como a escola seleciona, organiza e trabalha as obras literárias, naquilo que designamos de política literária.

Isso porque entendemos que a escola deixa de lado uma questão crucial: por que certas obras literárias podem circular na escola e outras não? Essa perquirição está diretamente atrelada à ideologia e aos sentidos, visto que certas obras literárias são legitimadas e outras interditadas no espaço escolar, o que significa dizer que certos sentidos podem estar presentes na escola e outros não.

A política literária, que será discutida com mais profundidade no capítulo 1, é aquela que legitima o que é literatura e o que não pode ser considerado literatura, aquilo que torna um escritor (a) e sua obra um clássico, ditado, muitas vezes, pelos críticos ou por aqueles que também estão legitimados a dizer, são as obras que ganharão prêmios e participarão das feiras literárias, que serão discutidas nas academias de Letras, difundidas na escola e em seu currículo, encontradas nas livrarias, ementas universitárias e editais de vestibulares.

Nessa discussão da política literária levamos em conta os três momentos relevantes no processo de produção do discurso de Orlandi (2012) - constituição (memória discursiva, interdiscurso), formulação (em condições de produção e circunstâncias de enunciação específicas) e a circulação, que se dá em certa conjuntura e segundo certas condições.

A constituição corresponde ao interdiscurso que pode ser representado no eixo vertical, temos, aqui, todos os dizeres já ditos e esquecidos sobre literatura; na formulação, eixo horizontal, encontramos o "momento em que o sujeito diz o que diz e em que se assume autor" (ORLANDI, 2012, p. 10), temos um investimento do corpo do sujeito atado ao corpo das palavras; por fim, a instância da circulação é "onde os dizeres são como se mostram" (idem, 2012, p. 11), é o trajeto dos dizeres, e isso nos interessa porque não há neutralidade no discurso.

A circulação dos discursos sobre a política literária - que é social, histórica e ideológica -contribui para o desconhecimento e/ou negação de certas autoras e autores, por exemplo, em relação às mulheres negras. Isso é fácil de ser constatado quando presenciamos a 
ausência de autoras negras na escola, nas livrarias populares, nas ementas universitárias, nas atrações das grandes feiras literárias e é essa deslegitimação o ponto nodal desta dissertação, porque defendemos que isso ocorre com a autoria de mulheres negras desencadeado pela relação desigual de poder que está presente na sociedade, discussão que aprofundaremos no primeiro capítulo.

A política literária se materializa por meio dos discursos que fazem com que circule socialmente enunciados como: Carolina Maria de Jesus não é literatura. Esse dizer sempre provocou discussão, que volta em cena devido aos vestibulares da Universidade Estadual de Campinas - UNICAMP - e Universidade Federal do Rio Grande do Sul - UFRGS, vozes de autoridade acadêmica, que colocaram em seu edital, 2017, uma obra dessa autora, Quarto de Despejo: diário de uma favelada (2014), lançado em 1960, em sua lista.

Outros enunciados como: Harry Potter é literatura? Rupi Kaur é uma poetisa de qualidade? As histórias em quadrinhos empobrecem a literatura e formam leitores preguiçosos? A literatura oral (e escrita) dos indígenas tem valor? As obras literárias comercializadas nas bancas são "entorpecentes ficcionais"? Como podemos notar, tudo gira em torno da legitimação ou desqualificação de determinados escritos e seus autores. Os sentidos dominates sobre literatura, considerada neste trabalho como um território político da palavra, são produzidos pela ideologia dominante que, por sua vez, legitima e interdita o que pode ou não ser considerado literatura de prestígio.

Ao tratar da política literária nesta dissertação, temos o objetivo de destacar que a discussão acerca do que é ou não é literatura constitui um ponto crucial no tocante a esse campo de conhecimento. Isso não significa menosprezar o trabalho dos críticos e teóricos literários, tampouco afirmar que qualquer disposição de produção textual é literatura, há críticos e críticos; há escritores e escritores, isso a escola tem o dever de trabalhar com seus educandos, visto que não fazemos a defesa de uma pedagogia da facilitação, pois, cada obra literária tem seu desafio; portanto, cabe à escola trabalhar as literaturas em sua pluralidade e não por meio de interdições.

O que buscamos inicialmente marcar é que o território literário é parte do jogo político social, em que a escola (e outras instituções) participa e contribui para a manutenção do estigma literário, discursivizando aos estudantes qual obra literária é de qualidade e qual não é, muitas vezes, reproduzidas pelos professores que, também, um dia ouviram dizer que determinada obra e autor são um clássico, discurso que se sustenta porque já foi legitimado, 
visto que há professores, mesmo aqueles formados em Letras, que sequer leram essas obras, sustentando os seus discursos sobre a literatura em sala de aula por meio da cristalização do gesto de leitura das vozes de autoridade, pelas classificações das obras em "classes/períodos literários" que provocam a ilusão da linearidade/unidade e a concepção de uma escola que serve apenas para transmitir/reproduzir esses conhecimentos.

Nesse cenário conflituoso, preferimos jogar o jogo da política literária não pela questão: isto tem valor e isto não tem valor, porque significaria continuar negando certas literaturas, mas, questionar por outra via, qual seja: quem está autorizado a se constituir como um sujeito-autor de literatura? Qual é a representação (imaginária) social de um sujeito-autor de literatura? Que literatura pode circular no currículo da escola e na sala de aula? Questões que serão desenvolvidas ao longo desta dissertação.

A partir das indagações formuladas anteriormente, para tratarmos da política literária acerca da questão sobre a legitimação e interdição das obras literárias, escolhemos trabalhar, como corpus da dissertação, as obras de Carolina Maria de Jesus, Quarto de Despejo: diário de uma favelada (2014), e Diário de Bitita (2016), por compreender que a literatura de Carolina joga o jogo da legitimação e o da interdição, pelo fato de a escritora autorizar-se a ocupar a posição de sujeito-autor, dentro de uma sociedade que tem o racismo estrutural integrando a organização econômica e política da sociedade de forma inescapável (ALMEIDA, 2019).

Deste modo, o objetivo desta pesquisa é investigar o modo como o sujeito-autor, nas obras selecionadas, relacionou-se com a escrita e se constitui autor de literatura. Especificamente, buscamos investigar, nas marcas de autoria desse sujeito, os efeitos de sentidos de resistência que fazem com que essa produção literária possa ser reconhecida como literatura de enfrentamento social, que joga o jogo da política literária, contribuindo, por fim, para refletirmos a ausência de autoras negras na escola e em outras instituições, apontando, portanto, alguns questionamentos acerca desse silenciamento.

A partir do que foi mencionado no parágrafo anterior, buscamos verificar nas marcas da autoria desse sujeito-autor, os efeitos de sentidos de resistências naquilo que designamos de "as fomes", a ruptura com a literatura-canônica, com o político literário-social e a política editorial. Também verificamos na tessitura do texto literário o enfrentamento social/ruptura/resistência, por meio dos conceitos de "mau-sujeito" e "bom-sujeito" de Pêcheux (2009), o "discurso-manhoso" e a literatura-filosófica refletida na escrita-indagante 
da autora.

Esperamos propor uma reflexão no que se refere à importância do acesso à literatura de autoria de mulheres negras, marcando a resistência simbólico-política delas perante uma sociedade que insiste em deslegitimar e interditar seus escritos.

A escola, como agência de letramento, tem a função de levar para dentro de seus espaços uma literatura plural, isto é, desde a canônica até as que ainda não são, visto que viabilizar a leitura é pensar sua multiplicidade de discursos e vozes, é instaurar a polissemia, por meio do discurso polêmico, isto é, o da disputa (ORLANDI, 2012). E quando falamos de literatura de autoria negra é importante salientar que a literatura produzida por mulheres negras é uma das mais negadas, pois é perpassada por questões que não podem ser discutidas apenas na esfera de classe, mas também, de raça, gênero e sexualidade, visto que:

A mulher negra, ela pode cantar, ela pode dançar, ela pode cozinhar, ela pode se
prostituir, mas escrever, não, escrever é alguma coisa... é um exercício que a elite
julga que só ela tem esse direito. Escrever e ser reconhecido como um escritor ou
como escritora, aí é um privilégio da elite. (EVARISTO, em entrevista concedida ao
blog, Blogueiras Feministas - De olho na Web e no mundo, em 30 de setembro de
2010).

É a partir dessas reflexões sobre o que significa ser uma mulher negra que se autoriza a ocupar a posição de sujeito-autor que analisaremos os escritos de Carolina Maria de Jesus, pois entendemos que eles contribuem para pensarmos as formações imaginárias a respeito do que é ser autor e do que é literatura.

No primeiro capítulo procuramos fazer uma discussão sobre o funcionamento da política literária, em que analisamos os discursos sobre o que é literatura, por sua vez, o que é uma obra clássica da literatura, assim como os sentidos do que seja um autor (imortal) das letras pertencentes ao cânone, pois acreditamos que essa reflexão é fundamental para encontrarmos e observarmos alguns dos motivos do silenciamento da literatura de autoria de mulheres negras.

Ainda nesse capítulo, também fazemos uma discussão sobre o mercado editoral, ponto essencial para observarmos o modo como as obras de Carolina Maria de Jesus foram publicadas e aceitas (ou não) pela crítica, nesse jogo da política literária da interdição e legitimação ao mesmo tempo. Esse jogo nos permite refletir sobre a influência do mercado editorial na política literária.

Por analisarmos as críticas preconceituosas e, por vezes, discriminatórias em relação à 
primeira publicação de Carolina Maria de Jesus - Quarto de Despejo: diário de uma favelada (2014), lançado na década de 60, do século anterior, observamos que discutir a estrutura desigual de poder da sociedade passava por um tema indispensável que iria além da questão de classe, a saber, a questão do racismo estrutural. Desse modo, também, no primeiro capítulo fazemos uma discussão sobre o funcionamento do racismo na interferência da política literária da autoria de mulheres negras, em especial, da autora analisada neste trabalho.

Em seguida, apresentamos as considerações teóricas do nosso método e metodologia de pesquisa, abordando os nossos passos de pesquisadores em relação às análises do corpus.

Por fim, no terceiro e último capítulo apresentamos as análises do corpus, em que procuramos apontar as marcas de autoria nos recortes do sujeito-autor, defendendo que se trata de uma literatura de enfrentamento social, permitindo que os sentidos sobre "as fomes", a escola, assim como a escrita-indagadora possam ser comprovadas como movimentos discursivos de resistência, logo depois, dissertamos nossas considerações finais.

Em relação à escrita desta dissertação é importante fazer um adendo: Não é possível separar questões teóricas daquelas do desenvolvimento analítico, pois isso consistiria numa impossibilidade teórica para a $\mathrm{AD}$; por isso, o texto desta dissertação vai se constituindo conforme a necessidade da discussão posta, mesmo sabendo que esse batimento pode provocar o risco de dificultar o trabalho de leitura para os interlocutores. No entanto, “trabalhar teoricamente é já fazer análise”, como disse Pfeiffer (1995); logo, uma (teoria) não pode estar separada da outra (análise). 


\section{POLÍTICA LITERÁRIA - NA TRAMA DA SALA DE AULA: UM AUTOR POUCO PROVÁVEL}

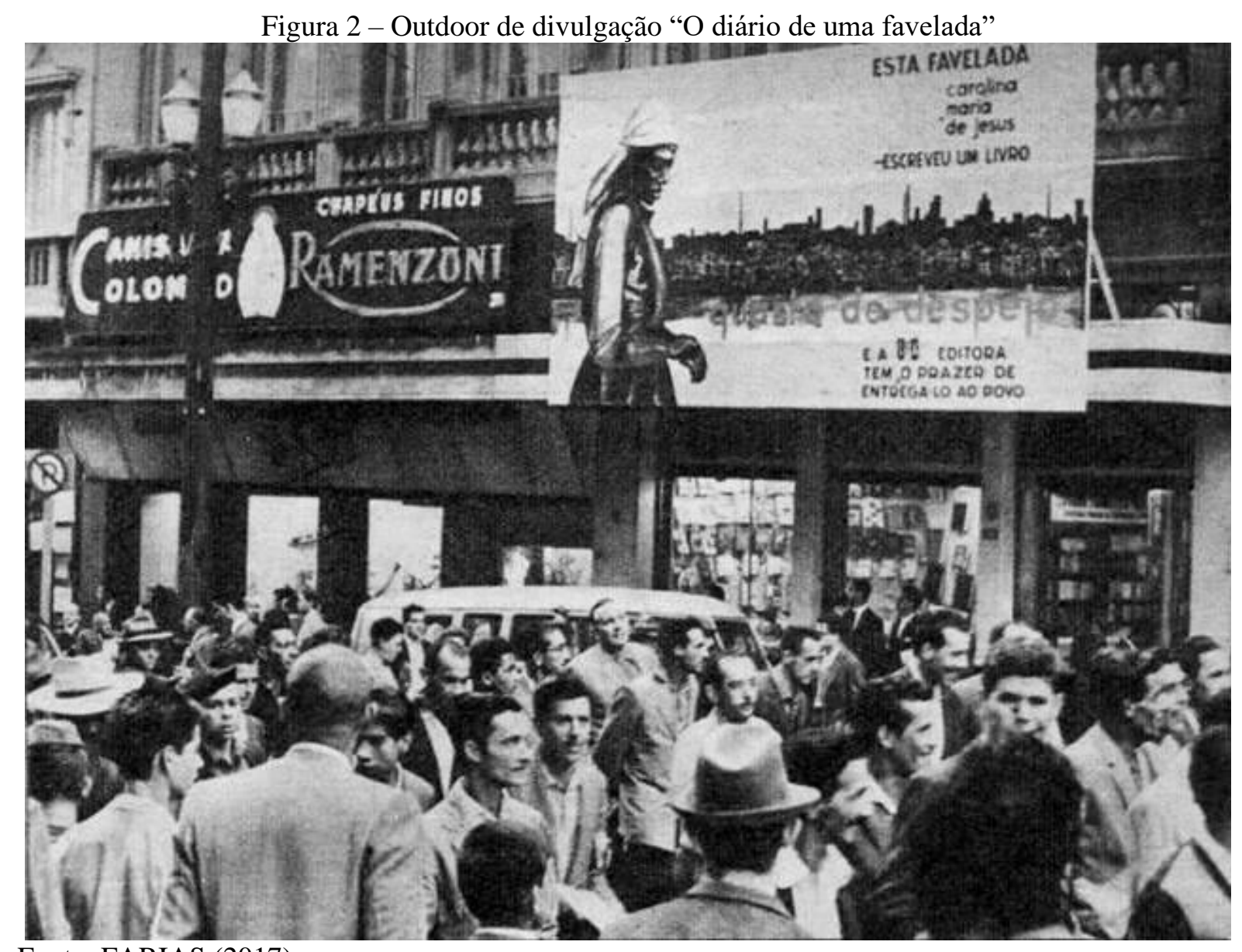

Fonte: FARIAS (2017)

Cansei-me dos poetas, dos velhos e dos novos: Superficiais eles todos são para mim, mares rasos. Não pensaram bastante sobre as profundezas: com isso seu sentimento não mergulhou até o fundo. Alguma volúpia e algum tédio: ainda é isso o melhor das suas reflexões. Um sopro e um deslizar de fantasmas me parecem todos os seus harpejos; que sabem eles até hoje do ardor dos sons!

Para mim tampouco são bastante puros: turvam todas as suas águas, para que pareçam profundas (NIETZSCHE, 2011, p. 381).

“A “literatura” pode ser tanto uma questão daquilo que as pessoas fazem com a escrita como daquilo que a escrita faz com as pessoas" (EAGLETON, 2006, p. 10). 
O estudante da Educação Básica ao ingressar no Ensino Médio depara-se com um campo de estudo "novo" dentro do conteúdo da Língua Portuguesa: a literatura. Em algumas escolas, o conteúdo de Língua Portuguesa passa a ser fragmentado em três áreas: Gramática; Redação e Literatura, concepção de língua e linguagem atrelada à teoria da comunicação (emissor-receptor-código). Todavia, esse sujeito-aluno, certamente, já teve acesso à literatura muito antes de chegar ao Ensino Médio. Por que, então, essa nomeação - literatura - só aparece nessa etapa educacional? Uma resposta possível é que há uma política literária que interfere na escola legitimando certas obras e escritores, muitas vezes, consideradas como clássicos literários (discussão que ainda abordaremos). É como se todas as literaturas trabalhadas antes do Ensino Médio não pertencessem a essa categoria dos clássicos, pautada em um discurso que imagina um leitor ideal que estará "pronto" para acessar essas obras legitimadas, em uma fase escolar ideal.

No entanto, ao acessarem as obras legitimadas, em especial, por meio do livro didático e das listas de vestibulares, nota-se que esse tempo e leitor ideais não dão conta para que o acesso e trabalho com a literatura na escola se torne algo prazeroso, muito menos produtor de um campo de conhecimento valorizado, que permita os gestos de leitura por parte dos sujeitos-leitores.

É como pronuncia Zarastruta, escrito por Nietzsche (2011) na epígrafe deste capítulo “(...) turvam todas as suas águas, para que pareçam profundas”, o que equivale a dizer que a literatura, "as águas", passam a ser discursivizadas pelos estudantes como difíceis de ler, chatos, entediantes, escrita para poucos (os cultos) e "sem graça"; portanto, "profundas demais", no sentido negativo, já que não é despertado o interesse pela literatura a esses sujeitos na escola.

O tédio da literatura não é uma consequência das obras literárias “clássicas" selecionadas pelo currículo da escola, mas está diretamente ligado à política literária que, ao legitimar uma obra, por sua vez, tende a cristalizar os sentidos que podem e devem ser lidos e ditos a respeito desses livros, cabendo ao sujeito-aluno decifrar e reproduzir.

Além do mais, as obras clássicas trabalhadas na escola, por meio dos livros didáticos, não dão conta do texto todo, por uma questão, sobretudo, comercial, que acarreta o acesso à literatura por meio de fragmentos e resumos dessas obras. O sujeito-aluno não vivencia a leitura da obra literária, mas pedaços dela, a partir da voz do professor, do livro didático, de resumos da internet (escrito e oral), ou seja, do outro e isso acarreta na reprodução dos 
sentidos ou até mesmo o abandono à literatura.

É nesse ponto que investimos a refletir: se nem os clássicos literários a escola consegue trabalhar, muito menos terá espaço a literatura de autoria de mulheres negras - que tende a ser interditada e discursivizada como não sendo clássicos literários - neste caso, em especial, a literatura de Carolina Maria de Jesus, foco desta dissertação.

O modo como as obras literárias são trabalhadas na escola, principalmente, as que estamos designando de clássicas (as legitimadas), não permite, de modo geral, o gosto pela literatura. Isso acontece porque são livros que não "conversam" com os sujeitos-alunos, pelo menos do modo como são abordados na escola e, por esse motivo, esses sujeitos passam a ansiar o "molde", ou seja, resumos e sentidos prontos acerca dessas leituras para serem aprovados nas avaliações escolares e nos exames de vestibular.

Esse molde é materializado na famosa "ficha de leitura" que não diz nada sobre o processo de leitura do sujeito-aluno. O molde também pode ser encontrado nos livros didáticos, apostilas, revistas, sites, que emolduram e compartimentam as obras literárias que passam a ser lidas a partir de uma só direção através de uma linha do tempo.

A maneira "estilística" de trabalhar a literatura (trataremos disso com mais detalhes, adiante) pode ser encontrada na escola por meio dos livros didáticos, nas revistas com enfoque literário, nas apresentações das obras literárias, nos sites de pesquisa que a escola utiliza, entre outros materiais, que enquadram as escritoras e escritores em determinada escola literária, a partir de um rol de características "comuns" que padronizam a direção de leitura dessas obras, em que cabe ao sujeito-aluno "apreender" esses ensinamentos a respeito dessas autoras e autores e suas obras para, assim, reproduzir nas atividades/avaliações escolares.

E quando há um autor ou autora que nunca ou pouco circula, o desafio fica ainda maior, já que o molde não está constituído, como é o caso das obras de Carolina Maria de Jesus que, por terem sido silenciadas, na escola, desde a década de 1960, surge agora em cena, sobretudo pela presença de um título na lista dos vestibulares da UNICAMP e da UFRGS - vozes de autoridade social - que selecionaram a obra Quarto de Despejo: diário de uma favelada (2014), na lista obrigatória do concurso dos seus vestibulares, exigindo da escola ter de buscar maneiras de trabalho a respeito dessa obra.

É por isso que cabe à instituição escolar não apenas a garantia ao acesso ao livro (físico ou virtual), mas, sobretudo, um trabalho que considere a participação dos sujeitos-alunos no mundo literário, autorizando-lhes a construir sentidos, de modo que a literatura faça-lhes 
algum sentido.

Uma maneira dessa garantia é a biblioteca da escola (quando existe) deixar de ser o sepulcro da poesia (LEANDRO, 2016) para passar a ser um espaço discursivo, em que os sujeitos-alunos se sintam parte desse lugar, podendo ter acesso a todas as obras e a tudo o que esse ambiente puder proporcionar: saraus, as rodas de leitura, peças de teatro, palestras, reuniões, estudos etc, ou seja, práticas que promovam o prazer da leitura e não a sustentação de uma imaginário estudantil que a vê como punição.

A biblioteca escolar é o lugar da discursividade literária, evidentemente, não somente da discursividade sobre literatura, mas é esta que nos chama a atenção, em que é possível trabalhar, não a leitura literal, mas a que exige do leitor um posicionamento sócio-históricoideológico, uma memória do dizer; portanto, trata-se de uma leitura dinâmica, "entendida como interpretação e interação do leitor com o mundo, possibilitando-lhe agir no mundo" (ROMÃO; PACÍFICO; 2006, p. 10).

A literatura no Ensino Médio ensinado por meio das classes literárias, também designadas de períodos ou estilos literários, que costumam abordar o contexto histórico, a biografia dos escritores e certa "estética" padronizadora das obras, nesse único formato de aula, não abre espaço para a leitura polissêmica (múltiplos sentidos) e, muito menos, para que o sujeito-aluno ocupe a função-leitor (PACÍFICO, 2012). Esse engessamento tende a gerar o desinteresse e o tédio por parte do sujeito-aluno.

É pelos motivos apresentados que a literatura na escola está fadada a ser discursivizada como um peso, como um estudo que exige dos alunos um esforço hercúleo. Os motivos são vários e alguns deles já foram apresentados: a falta de sustentação teórica em relação à prática docente; a cristalização do que pode e deve ser dito, a fragmentação do conhecimento atrelado a uma escola-fábrica, a desconsideração da voz do sujeito-aluno na construção dos sentidos a respeito das obras literárias; o currículo da escola que seleciona certas obras e desconhece e/ou nega outras, entre outros fatores.

O fracasso da literatura na escola está diretamente atrelado ao que designamos de política literária, política essa que legitima e interdita as obras literárias. Isso porque não existe prática docente neutra, já que defendemos, a partir de Freire (2018) que ser professor é um ato político, pois não é o discurso que sustenta a prática, mas a prática que deve sustentar o discurso, deste modo, a luta é por uma escola que trabalhe atrelada às pedagogias urgentes $e$ emergentes (GOMES, 2017), como é o caso da literatura de autoria de mulheres negras que 
suscita reflexão acerca do político na literatura.

As pedagogias urgentes e emergentes são um referêncial do campo da teoria crítica contemporânea, em que Nilma Lino Gomes (2017), ancorada nas reflexões de Santos (1996), defende uma educação crítica e emancipatória sustentada em Freire (2018), em que outras espistemologias e saberes produzidas pelos movimentos sociais, pela comunidade negra e pelo movimento negro sejam reconhecidas como válidas, isto é, o objetivo é transformar as ausências em presenças, pois a "pedagogia das ausências consiste em um posicionamento de vigilância epistemológica no que se refere ao campo da produção do conhecimento educacional" (GOMES, 2017, p. 63).

Segundo a autora, as ações afirmativas tocam na cultura política e nas relações de poder, já que as universidades públicas brasileiras que já implementaram ações afirmativas no Ensino Superior brasileiro, mediante políticas de aceso e permanência, têm que lidar com sujeitos sociais concretos, com outros saberes e modos de construir e se relacionar com o conhecimento, diferente da formação imaginária de estudamte universitário idealizado no país (branco, elitizado, alto grau de letramento, atrelado a uma epistemologia eurocentrica).

Cada vez mais temas como diversidade, desigualdade racial e vivências da juventude negra passam a fazer parte das discussões no contexto acadêmico, ainda assim, quando estão presentes, correm o risco de não figurarem como saberes "legítimos". daí podemos fazer uma analogia com a literatura de autoria de mulheres negras que, por meio do funcionamento da política literária ainda enfrenta o silenciamento, decorrente das relações desiguais de poder que têm a estrutura social racista em seu bojo (ALMEIDA, 2019).

$\mathrm{Na}$ educação, um modo de trabalhar esse conhecimento "não legítimo" seria por meio da “(...) pedagogia das ausências e da construção de uma pedagogia pós-abissal. Por meio delas poderemos considerar e incorporar a constelação de saberes/conhecimentos formulados no mundo" (GOMES, 2017, p. 66).

É por isso que a pedagogia das ausências e emergências pode contribuir para que a escola esteja atenta às questões (e conteúdos) ainda silenciadas em seu espaço, por exemplo, a literatura de autoria de mulheres negras.

O silêncio aqui não deve ser visto como a ausência de som, mas implica a exposição do que não é dito por meio do dito "o apagamento necessário que se faz às outras "palavras" e também da política do silêncio, isto é, o silêncio como agente da censura (ORLANDI, 1997). Ainda trataremos da questão do silêncio com mais profundidade. 
De nada adianta um sujeito-professor dizer que leva em conta a subjetividade dos sujeitos-alunos se, ao trabalhar com literatura no Ensino Médio, por exemplo, as cantigas trovadorescas, exige que seus sujeitos-alunos decorem os tipos de cantigas e suas características, isto é, cristaliza o trabalho com a literatura, não autorizando a voz do sujeitoaluno nesse processo, muito menos, alargando os saberes ao contexto sócio-históricoideológico, a partir das condições de produção dadas, portanto, não se tem um trabalho interpretativo nesse caso.

Muito menos, vislumbramos nesse recurso pedagógico da repetição a pedagogia das ausências e emergências em funcionamento, porque tudo já está dado, planejado, posto no livro didático e nas atividades práticas. Ao contrário disso, essa pedagogia exige que a escola esteja aberta ao diverso e à diversidade e mais, construa uma educação comprometida com práticas antiracistas.

Para Orlandi (2012) a escola se relaciona, muitas vezes, por meio do discurso autoritário que tende para a paráfrase (o mesmo) em que a polissemia é contida (procura-se impor um só sentido), não existem interlocutores, mas um agente exclusivo, sendo assim, o sujeito é um "instrumento de comando", ou seja, o sentido permitido é apenas "um", aquele que é legitimado, ficando preso a uma ideologia que não deixa o sujeito encontrar outras possibilidades de produção de sentido.

Esse funcionamento discursivo é observado em atividades de linguagem que a escola promove, descontextualizadas, marcadas pela repetição do "sentido único e verdadeiro" dos textos, em que muitos sentidos são interditados, cabendo ao sujeito-aluno reproduzir os sentidos autorizados em atividades como: O que o autor quis dizer? Quais são as três fases da poesia do período literário do Romantismo? Quem foi Luiz Vaz de Camões e qual sua obra mais importante? Quais são as características dos gêneros literários de Aristóteles?

As atividades que a escola trabalha, sustentadas no discurso autoritário, não permitem que os sentidos possíveis circulem em sala de aula e isso nos remete à política literária que funciona, conforme já dissemos, legitimando e/ou interditando certas autoras e autores e suas obras; todavia, esse é um processo que pode ocorrer ao mesmo tempo, pois ao trabalhar uma obra legitimada na escola, por exemplo, A hora da estrela (1998), de Clarice Lispector, presente nas listas de vestibulares e no livro didático, vozes de autoridade, certos sentidos são interditados, porque a escola trabalha na perspectiva da fôrma-leitor (PACÍFICO, 2012), portanto, interdita-se para que somente os sentidos legitimados estejam presentes, isto é, os 
sentidos que são autorizados.

No discurso autoritário, a questão da política literária funciona do seguinte modo: ao interditar certas autoras e autores e suas obras de circularem na escola, isso faz com que se interditem certos sentidos, a fim de legitimar outras autoras e autores e suas obras, consequentemente, os sentidos que podem e estão autorizados de circular nesta instituição.

Outra tipologia discursiva que Orlandi (2012) apresenta é o discurso polêmico, em que a polissemia é controlada e o referente é disputado pelos interlocutores, ou seja, cada sujeito do discurso pode participar da possibilidade de produzir sentidos plurais sobre o objeto discursivo.

O discurso polêmico não pode ser confundido com o discurso lúdico, em que tudo é aceito, independentemente do referente; no discurso polêmico é preciso que o discurso tenha um referente a ser discursivizado, por exemplo, em uma roda de leitura na biblioteca da escola os interlocutores disputam um objeto discursivo, A hora da estrela (1998), ou seja, todos podem falar sobre o que leem (compreendem) disputando os sentidos, em que uns podem, por exemplo, defender que Macabéa é uma personagem indefesa e outros não; e ainda outros sentidos podem vir a ser. Deste modo, Orlandi (2001) vai dizer que:

[...] uma sociedade como a nossa, pela sua constituição, pela sua organização e
funcionamento, pensando-se o conjunto de suas práticas em sua materialidade, tende
a produzir a dominância do discurso autoritário, sendo o lúdico o que vaza, por
assim dizer, nos intervalos, derivas, margens das práticas sociais e institucionais. O
discurso polêmico é possível e configura-se como uma prática de resistência e
afrontamento. (ORLANDI, 2001, p. 86).

A nosso ver, é no discurso polêmico que a política literária pode ser pensada, refletida, discutida, argumentada na escola, em que os interlocutores podem discutir a interdição e a legitimação não na busca e/ou defesa de um dos dois polos, mas, sobretudo, investigar o funcionamento dessa política literária que funciona como autorização do dizer. Desse modo, não se silenciam as obras de autoria de mulheres negras, antes, colocam-nas em cena, em que a disputa de sentidos se fará presente.

A política literária, sustentada no discurso polêmico não procura fixar as obras literárias em apenas uma única direção de sentidos, neste caso, a legitimação e a interdição são válidas como categorias para se pensar as relações de disputa que envolvem a literatura.

Essa política literária permite que os sujeitos consigam ocupar a função-leitor (PACÍFICO, 2002), eles duvidam da transparência dos sentidos e passam a indagar os 
sentidos que são autorizados e os que não são dessas obras, portanto, conseguem questionar por que certas obras são silenciadas e outras não; ou, por que certas obras estão presentes nas livrarias populares e outras não, ainda, por que certas obras só podem ser ditas a partir de determinados sentidos e não de outros.

No discurso polêmico a busca é pela garantia ao direito à literatura (CANDIDO, 1988), o que significa defender o direito às literaturas e de os sentidos possíveis para essas obras poderem circular e ser disputados.

Reconhecer esse estatuto de direito à literatura é admiti-la como um Direito Humano, isto é, partilhar de um pressuposto segundo o qual "aquilo que consideremos indispensável para nós é também indispensável para o próximo" (CANDIDO, 1988, p. 172), compreendendo que a literatura é um fazer humano de poder, "poder de convencimento, de alimentar o imaginário, fonte inspiradora do pensamento e da ação" (CUTI, 2010, p.10).

A literatura defendida como direito deve ser compreendida em um sentido amplo "desde o que chamamos de folclore, lenda, chiste, até as formas mais complexas e difíceis da produção escrita das civilizações" (CANDIDO, 1988, p. 174), por isso designamos de literaturas, isto é, no plural, para abarcar a diversidade em relação à literatura.

Assim como a garantia a certos bens fundamentais como a casa, comida, instrução, saúde, são importantíssimos (bens incompressíveis), também a literatura deve ser reconhecida como um bem fundamental, já que "incluir o semelhante no mesmo elenco de bens que reivindicamos está na base da reflexão sobre os Direitos Humanos" (CANDIDO, 1988, p. 172).

Todavia, ainda é possível observar discursos proferidos pela escola (professores, gestores) que sustentam um olhar negativo para a literatura, a saber: 1. Os estudantes não se interessaram; 2. Não estão prontos - "maduros" - para determinada literatura; 3. Não é um conteúdo relevante para a formação desses sujeitos. Esses discursos se sustentam no discurso de tipo autoritário de Orlandi (2012).

O primeiro discurso está atrelado a um "achismo" muito presente na escola, aliás, todo "achismo" é fruto da falta de embasamento teórico e deve ser combatido, ainda mais na sociedade contemporânea que tem sofrido a avalanche de fake news, tornando-se um dizer em relação ao sujeito-aluno que não permite nem a observação, isto é, a comprovação se esse discurso de que os discentes "não interessam por literatura" se sustenta ou não na prática.

Também resvala na questão sobre a prática pedagógica adotada pela escola, deste modo, 
esse discurso pode ser ligado ao modo como é trabalhada a literatura na escola que, por sua vez, não se responsabiliza por esse fracasso porque culpa o sujeito-aluno pelo desinteresse.

O segundo discurso esbarra, sobretudo, na concepção de língua e linguagem que recai na concepção de literatura (abordaremos essa questão mais à frente), as obras legitimadas tendem a pertencer a um cânone, partilhado por uma história e crítica literária que não consegue chegar até as escolas, ou, quando chega, tende a ser "didatizada" e/ou distante da vivência dos estudantes.

Mais uma vez se esbarra no trabalho do sujeito-professor com a literatura na escola, pois uma questão se torna fundamental: o sujeito-aluno não está "pronto" para a leitura e acesso à determinada literatura por quê? O que a escola compreende por estar "apto/maduro/pronto" para determinada leitura? O que a escola fez para sanar essa constatação?

Tudo indica que é um discurso preconceituoso e antidemocrático, sustentado em uma formação discursiva de autor e leitor ideal, afinal, é como se o sujeito-professor tivesse o direito a ler uma obra de Dostoievski; no entanto, os sujeitos-alunos, por não terem, imaginariamente, essa "competência-leitora" (concepção equivocada, reducionista, que não defendemos nesta dissertação), não podem ter o mesmo direito do sujeito-professor, visão sustentada em uma educação não emancipadora (FREIRE, 1999) em que o sujeito-professor se imagina o dono do saber.

O terceiro discurso tende a ser o mais emblemático por indiciar uma escola que coadjuva para a alimentação de um sério problema educacional: o discurso do fatalismo. Importa os saberes que não contribuem para a humanização, por exemplo, as que se ligam ao tecnicismo do "saber fazer" (manipular uma máquina).

Há um efeito ideológico que faz com que a literatura seja entendida como um saber de “enfeite”, isto é, cita-se um trecho de uma obra literária antes de iniciar um discurso em um determinando evento festivo a fim de embelezar o dizer. No entanto, sabemos que a literatura é o campo do improvável/rebuliço e, por isso, vai muito além de um mero acessório linguístico, deste modo, a literatura na escola tende a ser trabalhada de maneira superficial porque, à primeira vista, faz pensar e isso é perigoso, visto que a escola é o lugar do controle.

Entender a literatura como um conhecimento não relevante é, sobretudo, reconhecer que a sociedade vai mal, visto que "não há povo e não há homem que possa viver sem ela, isto é, sem a possibilidade de entrar em contato com alguma espécie de fabulação" (CANDIDO, 1988, p. 174). 
Toda essa discussão também nos levar a fazer um adendo: reconhecer o direito às literaturas não equivale a dizer que qualquer texto deva ser considerado literatura, já que os sentidos não podem ser quaisquer um, pois são determinados socialmente, historicamente e ideologicamente.

Por exemplo, não é por acaso que a obra, Quarto de Despejo: diário de uma favelada (2014), de Carolina Maria de Jesus, tenha sido escolhida na lista de obras obrigatórias de dois renomados vestibulares do país (UNICAMP E UFRGS), isto é, há sentidos que são suscitados quando uma obra literária é selecionada na lista desses vestibulares, nesses casos, o do esforço em prol da legitimação dessa autora e sua autoria: a obra de Carolina ao ser selecionada para a lista de vestibular ganha visibilidade e certo reconhecimento.

É importante notar que nenhuma escola trabalha genuinamente por meio do discurso polêmico, tampouco apenas pautado no autoritário, visto que tudo é movimento, isto é, uma escola pode atrelar-se a um ou outro tipo de discurso ao mesmo tempo.

A legitimação e a interdição de uma obra literária perpassam três questões fundamentais que não se encerram apenas nelas, no entanto, são um modo de percebermos o funcionamento dessa política: 1 . O que se discursiviza sobre o que é literatura; 2. O que se discursiviza sobre o que é um clássico literário e a defesa de certas obras e autores que constituirão o cânone; 3. E quais obras são comercializadas, ou seja, quais autoras e autores estão nas listas dos vestibulares, livros didáticos, ementas acadêmicas, feiras de livro e literatura, portanto, qual autor e obra podem circular socialmente a partir de uma lógica de mercado.

Esses três pontos citados no parágrafo anterior são elementares para observamos o funcionamento da política literária, no entanto, ao articularmos com corpus desta dissertação, por tratar de autoria de uma autora negra, a nosso ver, esses pontos se entrecruzam em uma discussão indispensável e necessária, a do racismo estrutural, porque é parte da ordem social (ALMEIDA, 2019) e, é por essa via central que passa a legitimação (ou não) das obras de Carolina Maria de Jesus perpassa, e de tantas outras autoras negras. Deste modo, trataremos a seguir do que consideramos racismo estrutural e depois abordaremos os três pontos essencias sobre a política literária citados.

Para isso, começaremos conceituando o que é racismo estrutural e qual a sua implicação na política literária, principalmente, quando a discussão é sobre autoria de mulheres negras. Para essa discussão, recorremos a Almeida (2019) que, a partir de autores importantes e reconhecidos da teoria crítica racial, colonialismo, imperialismo e capitalismo, sustenta sua 
tese sobre essa temática.

Em seguida, faremos uma discussão a respeito do conceito de literatura, por meio de diversos autores da teoria literária, observando, principalmente, as rachaduras discursivas quando se tenta conceituar esse campo de saber, ainda mais, quando se leva em consideração o político funcionando no literário.

Por sua vez, trataremos sobre o dicurso dos clássicos da literatura, isto é, autoras e autores e suas obras que são canonizadas, sacralizadas, legitimadas, colocadas nesse lugar dos "imortais", observando esse funcionamento discursivo que contribui para refletirmos sobre a política literária.

Por fim, abordaremos a questão do mercado editorial e da sua dinâmica, não de maneira aprofundada, mas o suficiente para observarmos o funcionamento da política literária em relação ao mercado, assim como a sua influência na legitimação e/ou interdição de autoras negras.

\subsection{A estrutura social de poder racista e a sua influência na política literária}

\footnotetext{
"Ocê pensa que caminho e estrada é tudo a mesma coisa, mas tá errado, minha fia. A estrada é uma coisa, o caminho é outra. A estrada é uma via, uma picada no mato, um cortado no chão e é muita. O caminho é quando ocê escolhe uma estrada pra seguir e chegar no seu lugar" - EXU TRANCA RUA (SILVA, 2006).
}

A Academia Brasileira de Letras (ABL) é uma instituição privada que foi inaugurada em, 20 de julho de 1897, e sua sede fica no Rio de Janeiro (RJ). A Academia é composta por 40 membros efetivos e perpétuos, e 20 sócios correspondentes estrangeiros e o seu objetivo é o cultivo da língua e da literatura nacionais.

A inauguração ocorreu em uma sala do museu Pedagogium, à Rua do Passeio, realizou-se a sessão inaugural, com presença de dezesseis acadêmicos. Machados de Assis fez uma alocução preliminar, seguido do $1^{\mathrm{o}}$ secretário, leu a memória histórica dos preparatórios, e o secretário-geral, Joaquim Nabuco, pronunciou o discurso inaugural.

Localizado no prévio do pavilhão francês, doado pelo governo francês, graças à inicitativa de Afrânio Peixoto, em 1923, presidente na época da ABL, e também do embaixador da França, Raymond Conty, o prédio é uma réplica do Petit Trianon, de 
Versalhes, erguido pelo arquiteto Agnes-Jacques Gabriel, entre 1762 e 1768.

A ABL, à semelhança da Academia Francesa, tem o cargo de "imortal" vitalício, por meio do lema Ad immortalitem, nesse sentido, a sucessão se dá apenas pela morte do ocupante da cadeira. Para se candidatar é preciso ser brasileito nato e ter publicado, em qualquer gênero da literatura, obras de "reconhecido mérito ou, fora desses gêneros, livros de valor literário", segundo informações do site da Academia.

Os imortais são escolhidos mediante eleição por escrutínio secreto, em que é declarada vaga na Sessão de Saudade quando um dos acadêmicos falace, deste modo, os candidatos tem dois meses para se canditarem por meio de uma carta enviada ao Presidente. A eleição acontece sessenta dias após a declaração da vaga e a posse é marcada de comum acordo entre o novo Acadêmico e o escolhido para recepcioná-lo.

A primeira mulher a integrar a lista dos imortais na ABL, em 1977, depois de 81 anos desde a criação, foi Rachel de Queiroz. Atualmente há cinco mulheres, a saber, Ana Maria Machado, Cleonice Berardinelli, Rosiska Darcy de Oliveira, Lygia Fagundes Telles e Nélia Piñon e somente um negro, Domício Proença Filho.

Em abril de 2018, Conceição Evaristo, mulher negra, nascida em uma comunidade periférica de Belo Horizonte, há 71 anos, foi impulsionada por movimentos negros e feministas a candidatar-se para a cadeira de $\mathrm{n}^{\circ} 07$ - Castro Alves - ocupada pelo falecido cineasta Nelson Pereira dos Santos (entre outros, como Euclides da Cunha e Afrânio Peixoto), porém, teve apenas 1 voto e perdeu para Cacá Diegues, um dos fundadores do chamado Cinema Novo.

A ideia da candidatura se alastrou nas redes sociais e a fã e pesquisadora Juliana Borges publicou, em 30 de abril, uma carta-manifesto ${ }^{1}$ em apoio à autora. A partir do texto, surgiram dois abaixo-assinados pedindo a entrada da escritora na ABL tendo, em dois dias, mais de 6,5 mil apoios, alcançado mais de 40 mil assinaturas na duas petições, que teve até uma hastag \#ConceicaoEvaristoABL.

Conceição Evaristo (Maria da Conceição Evaristo de Brito) é graduada em Letras pela Universidade Federal do Rio de Janeiro (UFRJ), mestre em Literatura Brasileira pela

\footnotetext{
${ }^{1}$ CAMPOS, M; BIANCHI, P. Conceição Evaristo: Ela seria a primeira escritora negra da Academia Brasileira de Letras. Mesmo com a maior campanha popular da história, perdeu. https://theintercept.com/brasil/. 30/08/2018. Disponível em: < https://theintercept.com/2018/08/30/conceicao-evaristo-escritora-negra-eleicao-abl/> Acessado em 23/05/2019.
} 
Pontifícia Universidade Católica do Rio de Janeiro (PUC) e doutora em Literatura Comparada na Universidade Federal Fluminense.

Como pesquisadora, Evaristo discute a questão da produção literária negra em relação à ausência de autoras e autores na representatividade social. Atualmente, Conceição leciona na Universidade Federal de Minas Gerais (UFMG) como professora visitante.

É uma das mais representativas escritoras negras afro-brasileiras contemporânea, com obras de poesia, ficção e ensaio publicadas. Estreou na literatura, em 1990, quando passou a publicar seus poemas e contos na série Cadernos Negros. Sua principal luta está no reconhecimento da mulher negra como produtora de saber e conhecimento legítimos.

Toda essa questão da candidatura da escritora Conceição Evaristo e do funcionamento da ABL nos remete a tratarmos do político na literatura. Conforme já apontamos, a política literária trabalha legitimando e/ou interditando autoras e autores e suas obras, a partir de disputas nem sempre tão fáceis de ser percebidas e objetivas, mas, por algumas vias indiciárias é possível observarmos os modos do seu funcionamento, não sem contradições, visto que isso é constitutivo dos discursos e, consequentemente, dos sujeitos.

A candidatura de Conceição Evaristo à $\mathrm{ABL}$ se deu, segundo ela, depois que soube da movimentação nas redes sociais e de movimentos sociais organizados em apoio a ela. É possível observar, por meio da foto abaixo, a escritora subindo as escadas do prédio da academia, no dia 18 de junho de 2018, indo fazer a sua inscrição à vaga.

Figura 3 - Conceição Evaristo subindo as escadas da ABL no dia da sua candidatura a uma das cadeiras

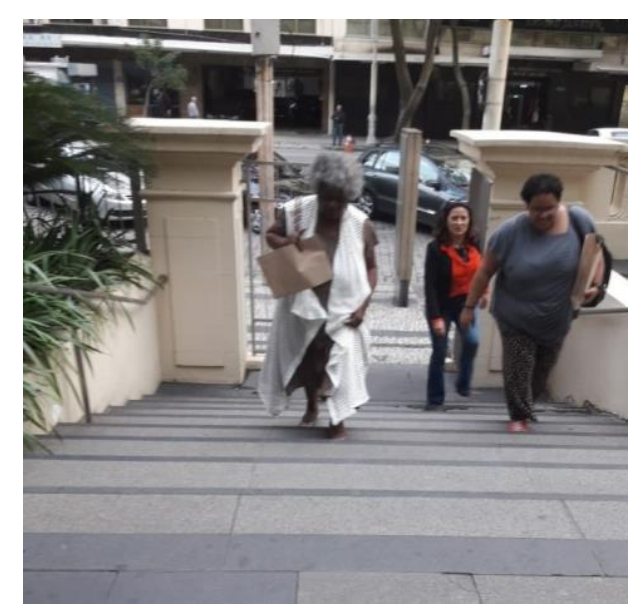

Fonte: DESACATO (website) $)^{2}$

${ }^{2}$ CONCEIÇÃO Evaristo é oficialmente candidata à Academia Brasileira de Letras. 2018. Disponível em: 
A fotografia como discurso é potente para refletirmos a posição discursiva da autora que teve a coragem de enfrentar uma instituição que nunca acolheu uma mulher negra em sua composição de membros. Nela, Conceição Evaristo leva em suas mãos a sua carta ao presidente, representação simbólica da voz de outras mulheres negras, sobretudo, mulheres negras que escrevem e produzem literatura.

É o "eco-voz liberdade" de tantas outras mulheres negras que já subiram, metaforicamente e literalmente, as escadas a fim de conquistar seu espaço e voz na sociedade. Representação do sujeito-negro que sobe, isto é, que resiste, alteia, aparece, incomoda, desestabiliza o sistema. Sujeito que "fede" (ainda trataremos disso).

$\mathrm{O}$ ato político-simbólico discursivo de Conceição Evaristo subindo as escadas da ABL, leva-nos a estabelecer uma analogia com Carolina Maria de Jesus, que também enfrentou muitas "escadas" em sua vida, algumas, nem pôde subir, como mulher, negra, mãe, escritora. Histórias de mulheres negras que se cruzam e se tra(n)çam, mesmo em meio a condições de produção outras, isso porque a ideologia dominante sustentada na estrutural social racista legitima a interdição da autoria de mulheres negras.

Tocar no ponto da representatividade é elementar porque constitui um modo de enfrentar a deslegitimação da autoria de mulheres negras, por meio do desconhecimento e/ou negação das suas escritas, fazendo com que os sujeito-negros tornem-se sujeitos-resistência por buscarem estratégias para que suas produções possam ser (mais) visíveis e acessadas diante dessa estrutura social racista.

No caso da autoria de mulheres negras a interdição às suas escritas e obras se dá por conta do jogo político que funciona na literatura diante da escolha dos "sujeitos-imortais" das letras, perpassada pela questão do racismo que está presente na vida contidiana e, sendo inerente à ordem social, a única forma de combatê-lo é “(...) por meio da implementação de práticas antirracistas" (ALMEIDA, 2019, p. 48).

Não ser racista é não se sentir compactuado com o processo de inferiorização e violência com certos grupos despreviligiados da sociedade, no entanto, é pouco, pois é preciso ir além, isto é, ter ações, práticas antirracistas, refletir sobre as relações políticas, econômicas, ideológicas da sociedade, isto é, não deixar silenciada a questão racial, criando meios de

<http://desacato.info/conceicao-evaristo-e-oficialmente-candidata-a-academia-brasileira-de-letras/>. Acesso em: 13 nov. 2018. 
enfrentamento/desconstrução/resistência contra essas estruturas de poder racistas.

Mas o que vem ser o racismo estrutural? Antes de mais nada, é importante compreender o conceito de raça, que só pode ser pensado no campo da história, sociologia, antropologia, porque o sentido de raça não se mantém o mesmo ao longo da história, até porque dentro de um mesmo período histórico o conceito de raça, a depender das condições de produção, tem sentidos diferentes.

Raça pode ser pensado na esfera de características físicas e biológicas de algum sujeito (empírico); ou raça no sentido de um pertencimento a certas práticas culturais em que os sujeitos (também empíricos) são racializados porque comungam das mesmas práticas. Raça pode ser, ainda, a união dessas duas facetas. É importante dizer que quem cria o racismo é o sujeito-racista e não o inverso:

Raça como características biológica, em que a identidade racial será atribuída por algum traço físico, como a cor da pele, por exemplo. Raça como característica étnico-cultural, em que a identidade será associada à origem geográfica, à religião, à língua ou outros costumes. (ALMEIDA, 2019, p. 30-31).

Almeida (2019) argumenta que raça em si não explica nada, no entanto, o conceito de raça foi feito para criar divisão entre as pessoas, para causar confusão social, no sentido de que, por meio dela é possível estabelecer e justificar meios de intervenção e controle, por tratar-se de um conceito relacional e histórico. Isso é fácil de ser observado, por exemplo, nos eventos da Segunda Guerra Mundial e o genocídio perpetrado pela Alemanha nazista que "reforçaram o fato de que a raça é um elemento essencialmente político, sem qualquer sentido fora do âmbito socioantropológico" (idem, 2019, p. 31).

Ao tratarmos de raça se faz necessário conceituarmos a diferença entre preconceito racial e discriminação racial para, assim, conceituarmos o racismo.

Almeida (2019), atrelado a diversos autores importantes das teorias críticas raciais, colonialismo, imperialismo e capitalismo, vai dizer que o preconceito racial está ligado a juízos de valor baseados em estereótipos acerca de indivíduos que pertençam a um determinado grupo racializado, estabelecido por fatores sociais-históricos, incluímos, também ideológicos; já a discriminação racial é o ato de atribuir tratamento diferenciado a membros de grupos racialmente identificados, portanto, está ligada às questões do poder, podendo ser direta ou indireta: 
negros, judeus, muçulmanos, pessoas de origem árabe ou persa, ou ainda lojas que se recusam a atender clientes de determinada raça. (...) Já a discriminação indireta é um processo em que a situação específica de grupos minoritários é ignorada (...). (ALMEIDA, 2019, p. 32-33).

A partir dessas definições de preconceito e discriminação racial, chegamos ao conceito de racismo que é "uma forma sistemática de dicriminação que tem a raça como fundamento" (ALMEIDA, 2019, p. 32). O racismo se manifesta por meio de práticas (conscientes e incoscientes) que desencadeiam privilégios e desvantagens para indivídos, a depender do grupo social ao qual pertençam.

Ao contrário de grande parte da literatura que utiliza os termos racismo institucional e racismo estrutural como sinônimos, Almeida (2019) argumenta que não funcionam na equivalência e, de modo didático, apresenta três classificações do racismo: o individualista, o institucional e o estrutural.

O racismo individualista sustenta a ideia de "patologia" ou anormalidade, sob esse ângulo, não existiria racismo institucional, mas indivíduos racistas, que agem isoladamente ou em grupo, praticando preconceito racial ou discriminação direta, recaindo na natureza psicológica, deixando de lado a natureza política do racismo. Deste modo, limita-se a aspectos comportamentais e a discursos como: "somos todos humanos", "racismo é errado", entre outros sentidos, cabendo ao Estado a punição e controle dos indivíduos racistas.

O racismo institucional, por sua vez, não se reduz a comportamentos individuais, mas é o "resultado do funcionamento das instituições, que passam a atuar em uma dinâmica que confere, ainda que indiretamente, desvantagens e privilégios com base na raça” (ALMEIDA, 2019, p. 37 - 38), o efeito disso é que essas instituições atuam a partir de mecanismos discriminatórios, como também podem ser atores que estabelecem novos significados à raça, inclusive possibilitando certas vantagens a certos grupos raciais historicamente discriminados.

Um modo de observarmos o racismo institucional diz respito ao baixo número de sujeitos-negros em cargos como os de promotres, juízes, políticos, médicos, professores, gerentes de banco, entre outros; outro exemplo é o modo como algumas instituições comerciais selecionam seus funcionários, por meio de um currículo que solicita a fotografia do candidato, pois, sua aparência está no "pacote" de escolha e perfil buscado pelas empresas. Assim sendo, a depender do cargo, sujeitos-negros são eliminados no processo seletivo, a começar, pela sua aparência.

É o racismo estrutural que permite, segundo Almeida (2019), que o racismo institucional 
seja visto como materialização de uma estrutura social, ou seja, o racismo não é criado pelas instituições, na verdade, elas o reproduzem; consequentemente, é justamente a existência de instituições que não tratam de maneira ativa e como um problema de desigualdade racial que são as primeiras facilmente a reproduzirem práticas sociais racistas naturalizadas, em que o único meio de combatê-las é implementando práticas antirracistas.

É nesse ponto que entra a pedagogia das urgências e emergências (GOMES, 2017) porque está ligada à prática antirracista, isto é, ultrapassa a discussão de raça apenas no campo moral (racismo individualista) em que a escola ancora-se, o que não garante a transformação social, pois discutir raça e racismo implica, necessariamente, discutir história, política, economia, ideologia, poder, portanto é tratar de conflito e a educação está mais na ordem do autoritário (ORLANDI, 2012) do que da emancipação (hooks ${ }^{3}$, 2013), deste modo, a pauta do racismo não pode estar separada da educação.

O racismo estrutural permite um passo ainda maior na discussão do racismo em relação ao institucional, porque aquiesce pensar o racismo como parte da estrutura e:

\begin{abstract}
A viabilidade da reprodução sistêmica de práticas racistas está na organização política, econômica e jurídica da sociedade. O racismo se expressa concretamente como desigualdade política, econômica e jurídica. Porém o uso do termo "estrutura" não significa dizer que o racismo seja uma condição incontornável e que ações e políticas institucionais antirracistas sejam inúteis: ou, ainda, que indivíduos que cometam atos discriminatórios não devam ser pessoalmente responsabilizados. (...) O que queremos enfatizar é que o racismo como processo histórico e político, cria as condições sociais para que, direta ou indiretamente, grupos racialmente identificados sejam discriminados de forma sistemática. (ALMEIDA, 2019, p. 51).
\end{abstract}

O racismo está presente nas relações sociais, políticas, jurídicas e econômicas de maneira naturalizada, no entanto, como o autor apresentou, ações e políticas antirracistas são importantes, criando o efeito de sentido de que a responsabilização individual e institucional por atos racistas não dessaraiga a reprodução da desigualdade racial:

Assim, detêm o poder os grupos que exercem o dominínio sobre a organização política e econômica da sociedade. Entretanto, a manutenção deste poder adquirido depende da capacidade do grupo dominante de institucionalizar seus interesses, impondo toda a sociedade regras, padrões de conduta e modos de racionalidade que tornam 'normal' e 'natural' o seu domínio. (ALMEIDA, 2019, p. 31).

\footnotetext{
${ }^{3}$ Gloria Jean Watkins é escritora e militante feminista. Adotou como pseudônimo o nome da sua avó (bell hooks), por isso a letra minúscula, que desafia convenções linguísticas e acadêmicas, pretende dar enfoque ao conteúdo da sua escrita e não à sua pessoa, conforme desejo da autora.
} 
Se o grupo dominante depende da sua capacidade de articulação política para a manuntenção do seu poder, pela teoria discursiva, compreendemos que é possível a ruptura, o deslize, o diferente, em que os objetos ideológicos “(...) têm uma estranha propriedade de ser ao mesmo tempo idênticos e antagônicos entre si” (PÊCHEUX, 2015, p. 97), portanto, para nós, analistas de discursos, o "valor político e histórico da falha" (idem, 2015, p. 105) é algo importantíssimo a se considerar.

No caso da autoria de mulheres negras, a fratura com o "grupo dominante" está justamente na questão da autoria, isto é, em quem pode e tem o direito de dizer e produzir sentidos, também diz respeito sobre qual literatura importa, pois, os diários de Carolina Maria de Jesus podem ser reduzidos a relatos de uma mulher sobre o seu cotidiano, desconsiderando-os como voz literária legitimada.

No século XX, muitos estudos foram feitos sobre as diferenças raciais, teses que corroboraram para a inferiorização dos sujeitos-negros e a manutenção da supremacia dos sujeitos-brancos - a supremacia branca é uma forma de racismo centrada no conceito que os sujeitos-brancos são superiores aos sujeitos-negros e, portanto, devem governar politicamente, economicamente e socialmente os sujeitos-negros. Como podemos observar, esses pesquisadores estão ancorados no sujeito-empírico e pautados no preconceito e discriminação racial.

Um exemplo dessas teses é o mito da democracia racial, que cria um efeito de sentido de que o Brasil é um país miscigenado, portando, cordial, servindo para apontar que as políticas de combate ao racismo sejam vistas como desnecessárias, ainda mais quando se está fundamentado na ideia de meritocracia, isto é, o entendimento que se os sujeitos-negros se esforçarem poderão usufruir dos mesmos direitos e privilégios dos sujeitos-brancos, isso faz com que o debate sobre a estrutura social do racismo fique ainda mais silenciado, visto que:

(...) O Brasil construiu, historicamente um tipo de racismo insidioso, ambíguo, que se afirma via sua própria negação e que está cristalizado na estrutura da nossa sociedade. Sua característica principal é a aparente invisibilidade. Essa invisibilidade aparente é ainda mais ardilosa, pois se dá no mito da democracia racial, uma construção social produzida nas plagas brasileiras. Através da narrativa do mito, que é extremamente conservadora - porém transfigurada em discurso democrático -, a igualdade das raças é destacada. Trata-se, no entanto, de uma falsa igualdade, pois ela se baseia no apagamento e na homogeneização das diferenças. (...) Um dos méritos do Movimento Negro ao longo dos tempos tem sido o fato de desvelar esse discurso e, ao fazê-lo, colocar a sociedade brasileira cara a cara com o seu racismo. (GOMES, 2017, p. 51). 
Para Almeida (2019) os estudos sobre desigualdade social foram utilizados para justificar a inferioridade dos sujeitos-negros, pois não fazem críticas sobre a condição do negro na sociedade. Segundo o autor, é o Estado quem organiza e define o funcionamento político da sociedade, portanto, define as práticas sociais em favor do grupo dominante, o que faz reproduzir o racismo, nunca do mesmo modo, mas a partir de estratégias mais ou menos eficazes de manutenção.

A ideia de nacionalismo que ressoa sentidos de um povo homogêneo, no interior de um território e sob soberania, corrobora para que alguns costumes e culturas sejam excluídos em "favor da nação", sustentados, inclusive, no discurso da civilização, o ideal de "homem cordial e educado".

Esse discurso de um Brasil patriota tem voltado a circular na sociedade vindo, principalmente, de alguns políticos partidários com grande impacto, pois é um modo conveniente/convincente de manipulação social, na busca de adeptos para as suas pautas extremistas e antidemocráticas, visto que é preciso construir um "Brasil para todos", em que o pronome indefinido "todos", na prática, ironicamente, é na verdade "definido" e singularizado, ainda mais quando se utiliza o nome de "Deus" que é evocado como estratégia discursiva.

Na dissertação de mestrado de Marielle Francisco da Silva (2014), socióloga, política e feminista, mais conhecida como Marielle Franco, assassinada, em 14 de março de 2018, junto ao motorista Anderson Pedro Mathias Gomes, ela, defensora dos Direitos Humanos, defende a tese que as Unidades de Política Pacificadora (UPPs), como política de segurança pública adotada no estado do Rio de Janeiro, reforçam o modelo de Estado penal.

A autora faz um estudo sobre o significado das UPPs pela perspectiva da Segurança Pública fundamentado nos elementos da Administração Pública, averiguando quais as relações contidas nestas Unidades, intrínsecas ao processo de elaboração e consolidação de políticas na área de segurança pública. Segundo ela, as UPPs configuram-se como "maquiagem" de políticas públicas de segurança, pois a partir do discurso da "insegurança social", aplica uma política voltada para repressão e controle dos pobres, por meio do cerco militarista nas favelas e do processo crescente de encarceramento, principalmente, dos sujeitos-marginalizados, cada vez mais colocados nos guetos das cidades e das prisões.

A esse respeito, Almeida (2019, p. 96) diz que a dissertação de mestrado de Marielle 
Franco aborda o elemento racial inserido nas ações de intervenções militares nas periferias do Rio de Janeiro, submetendo o grupo estigmatizado a coerções de todos os tipos, subalternizando, portanto, o modo legítimo de funcionamento da estrutural social racista que passa pelo institucional.

Depois dessa discussão sobre raça e racismo, ao costurar com o assunto introdutório sobre a ABL e a candidatura da escritora Conceição Evaristo, temos condições de observar a $\mathrm{ABL}$ inserida em uma sociedade que tem a estrutura social do racismo em seu bojo. A academia como uma instituição de grande repercursão e representatividade social, ao não ter em sua composição de membros, até a atualidade, uma mulher negra contribui para o desconhecimento e/ou negação da autoria de mulheres negras, assunto central neste trabalho, em que o mesmo ocorre com a instituição escola em relação ao seu currículo.

Não é possível afirmar que a $\mathrm{ABL}$ é despreocupada com as questões da autoria dos sujeitos-negros e também não significa que essa instituição deveria ter escolhido Conceição Evaristo, pois é permeada pelas suas regras tradicionais de cerimônia que devem ser respeitadas, todavia, não isentas de serem questionadas.

Conforme já foi argumentado, a representatividade por si só não garante a eliminação do racismo estrutural, mas é uma via importante de resistência, porque fura e abre caminhos, isto é, novas possibilidades de sociabilidades políticas, no caso da literatura, outras geografias de produção literária.

As relações do cotidiano no interior das instituições correm o risco de "reproduzir as práticas sociais corriqueiras, dentre as quais o racismo, na forma de violência explícita ou microagressões (piada, silenciamento, isolamento etc) (ALMEIDA, 2019, p. 48). Nesse sentido, se a $\mathrm{ABL}$ não é racista, ao menos podemos afirmar que ela não contribui para uma prática antirracista.

A prática antirracista constitui no enfrentamento do racismo como pauta fundamental na remoção de obstáculos que não permitem, por exemplo, que a autoria de mulheres negras alcance posições de prestígio nas instituições. Inclui deslocar a política literária desse lugar pré-determinado - legitimação e/ou interdição - para o campo da disputa e direito aos sentidos, a começar pelo reconhececimento de que o acesso aos saberes constitui uma prática antirracista.

Toda essa discussão teórica sobre racismo estrutural contribui para que a pauta sobre esse assunto não seja vista como menor, desembocando uma discussão que precisa estar presente 
na academia. No entanto, os estudiosos apresentados para sustentar essa discussão tratam o sujeito de modo empírico, diferentemente de nossa concepção, pois, para nós analistas de discurso:

(...) o alcance da discursividade é inerente a processo ideológico (...) a análise de discurso deixa de ser uma questão de reconstrução das variantes homogêneas de uma estrutura de ideologia (ou ideologias) para ser, em vez disso, uma questão de exploração desse jogo de heterogeneidades discursivas móveis que geram eventos específicos às lutas ideológicas do movimento. (PÊCHEUX, 2015, p. 98).

A nosso ver, de acordo com a "exploração desse jogo de heterogeidades discursivas móveis", a ABL produz uma formação discursiva atrelada às formações imaginárias do que seja um autor ideal, que poderá ter o mérito de ser considerado um "imortal" das letras. Isso indica que a $\mathrm{ABL}$, como tantas outras instituições, gera em suas decisões seculares de escolha de membros, modos e práticas de colaboração para uma certa "fixidez" do que seja um autor.

No entanto, a subida das escadas da ABL realizada pela escritora Conceição Evaristo representa a resistência, o furo, a possibilidade de a "fixidez" ranger, como um ato político frente a uma sociedade que ainda silencia as vozes das mulheres negras.

O mesmo ocorreu com Carolina Maria de Jesus que, nos anos 60, do século XX, desestabilizou o mercado editorial e o silenciamento da autoria de mulheres negras na sociedade da época, ocupando espaços nunca "antes navegados" por uma mulher negra periférica.

Isso significa que ao mesmo tempo que o racismo estrutura as relações sociais de poder, por outro lado, é uma estrutura que tem em seu cerne a contradição marcada pela resistência.

Orlandi (2012) diz que no discurso da classe média, ou se tem o conhecimento dominante ou se tem um menos abstrato, considerado menos austero, o da facilidade, o vil. A autora conclui que se trata de saber nenhum, pois os dois extremos produzem reducionismos ao se valerem de tudo ou nada.

A autora ainda argumenta que "há formas de saber que são diferentes e que têm funções diferentes" (ORLANDI, 2012, p. 48) e isso se dá por causa de uma sociedade que é dividida, em que há as formas legítimas e as que não são legítimas (que têm de legitimar-se). Deste modo, quando se adota o considerado conhecimento legítimo, “(...) através do discurso que propõe o acesso necessário a ele, desconhece-se a luta de classes, a luta pela validade das diferentes formas de saber, bem como a resistência cultural (idem, 2012, p. 48). Nessa 
discussão, acrescentaríamos o desconhecimento não só da luta de classes, mas também, do funcionamento do racismo, materializado em discursos, partindo do pressuposto de que a questão de classe, sozinha, não dá conta do elemento da estrutura social racista.

O ponto central não é "brigar" para decidir quais questões são mais importantes, visto que isso seria novamente cair no reducionismo apontado pela autora. $\mathrm{Na}$ verdade, propomos alargar a discussão de classes trazendo o racismo para junto da dela, principalmente, porque é um trabalho acadêmico que discute autoria de mulheres negras; portanto, não nomear o racismo é continuar contribuindo para que essas questões sejam vistas ou como menores, ou como discussão que deve ser feita apenas na esfera da classe social.

Concordamos com Orlandi (2012, p. 48) quando diz que se deve reinvindicar politicamente o acesso às formas legítimas de conhecimento e, ao mesmo tempo, criar novos espaços de produção de outras formas de conhecimento. Reivindicar outras formas de conhecimento nos permite defender a questão do racismo como um saber que precisa tornarse legítimo, caso contrário, perpertuar-se-á na dinâmica político-social de forma naturalizada, impedindo, por exemplo, que a autoria de mulheres negras seja reconhecida como um direito, desconstruindo discursos preconceituosos e discriminatórios a respeito dessa literatura.

Acreditamos que a discussão de Almeida (2019) sobre racismo estrutural avança para outros olhares sobre ética, estética e política que vão sendo desenvolvidos e discutidos, colocando-se em pauta as (im)possibilidades de que os sentidos sempre podem ser outros e se realizar em outros lugares, em outras vozes.

Toda discussão engendrada até aqui, de acordo com Almeida (2019) sobre a estrutura social racista, parte de uma base que faz suas discussões teóricas focalizadas no sujeito empírico. Deste modo, corre-se o risco de o leitor ser afetado por um efeito de sentido de que estamos deixando a teoria discursiva de fora, ou, embaralhando, contradizendo, os conceitos da $\mathrm{AD}$ que ancoram este trabalho; entretanto, na verdade, não é isso que ocorre.

Isso porque, discutir o racismo, ainda mais entendendo-o como estrutura social, ajuda o analista de discurso a ampliar uma discussão sobre o poder para além da questão de classes sociais apenas. No entanto, para a $\mathrm{AD}$ a ruptura está sempre em jogo, portanto, a estrutura social racista está o tempo todo sendo afetada por movimentos discursivos de resistência e a autoria de mulheres negras é um desses movimentos que procura furar o que se pretendia "semanticamente estabelizidado" (PÊCHEUX, 2009). O esforço é em marcar que essas discussões não podem estar ausentes, porque são emergentes (GOMES, 2017). 
É só observarmos o Decreto n ${ }^{\circ} 1331$, do dia 17 de fevereiro de 1854, conhecido como Reforma Couto Ferras, que aprovou medidas de regulamentação do ensino primário e secundário. O Decreto tornou gratuitas, na Corte, as escolas primária e secundária, sendo a primeira delas obrigatória aos maiores de sete anos, no entanto, estabeleceu que os sujeitosescravizados não poderiam ser admitidos nas escolas públicas do país, em nenhum dos níveis de ensino:

\footnotetext{
Art. 69. Não serão admitidos á matrícula, nem poderão frequentar as escolas: $\S 1^{\circ} \mathrm{Os}$ meninos que padecerem de moléstias contagiosas; $\S 2^{\circ}$ Os que não tiverem sido vacinados; $\S 3^{\circ}$ Os escravos.

Art. 85. Não serão admittidos á matricula, nem poderão frequentar o Collegio, os individuos nas condições do Art. 69. (BRASIL, 1854, p. 276).
}

No corpo-textual dos artigos 68 e 85, do Decreto n ${ }^{\circ} 1331$, é possível observar o discurso racista em funcionamento nos documentos legais, no modo como o poder político cria suas estruturas de poder a fim da sua manutenção. Corre-se o risco desse Decreto ser lido apenas pela questão de classe, no entanto, nomear um sujeito de "escravo" é ter no cerne a questão racial posta.

A educação, vista do pressuposto de uma instituição que pode (ou não) contribuir para a transformação social é algo perigoso, ou até mesmo outro pressuposto que enuncia a educação como algo para os "sujeitos-civilizados", portanto, para poucos, discurso ainda presente nas escolas contemporâneas quando discursivizam que determinados sujeitos-alunos não deveriam/merecem estar na escola, porque suas condições sociais os impedem de se constituírem como sujeitos-alunos "bons", isto é, aqueles que reproduzem o conhecimento autorizado e transmistido pela escola.

Carolina Maria de Jesus em, Diário de Bitita (2016), mostra o modo como as escolas brasileiras, na primeira metade do século $\mathrm{XX}$, traziam o fator racial na justificativa de suas práticas pedagógicas desiguais e competitivas, dentro da instituição escolar, inclusive, sentidos de segregação, conforme trataremos no terceiro capítulo.

Por fim, cabe dizer que, como argumenta Pêcheux (2015) sobre a questão da ideologia do ponto de vista da "reprodução das relações de produção capitalistas", por várias razões, "reprodução" faz significar a análise marxista a uma teoria pura de transformação social, no entanto: 
necessariamente implica, para um marxista, em também considerá-la do ponto-devista da resistência (grifo do autor) à reprodução, ou seja, da perspectiva de uma multiplicidade de resistências e revoltas heterogênas que se entocam na ideologia dominante, ameaçando-a constantemente (...). (PÊCHEUX, 2015, p. 96).

Com essa citação de Pêcheux é possível considerar que as ideologias dominadas não devem ser vistas como "micro-organismos ideológicos pré-constituídos", com tendência a se desenvolver de tal forma que é capaz de substituir simetricamente a dominação da ideologia dominante, mas, implica em "considerá-las como uma série de efeitos ideológicos que emergem da dominação e que trabalham contra ela por meio das lacunas e das falhas no seio dessa própria dominação" (PÊCHEUX, 2015, p. 97), pois, se assim não fosse, nem teríamos a possibilidade de escrever e trabalhar com o tema de autoria de mulheres negras nesta dissertação, porque o mundo seria "semanticamente estabelizado" e Pêcheux (2009) nos mostrou que isso é da ordem do impossível.

Portanto, a discussão sobre o racismo ajuda-nos a trabalhar a questão do político na literatura desnudando um modo de poder social que impede certas autorias; no entanto, pelo fato de a contradição e a opacidade serem constitutivas do discurso, a ruptura "bate à porta do estruturado" a todo instante, fazendo falhar certas coerções discursivas racistas de imposição da ideologia dominante, por meio da resistência e seus ruídos.

Os discursos racistas que contribuíem para a manutenção dessa estrutura de poder estão o tempo causando e sofrendo seus efeitos e é nesse jogo que vislumbramos a autoria de mulheres negras, em especial, a escrita literária de Carolina Maria de Jesus, como resistência que fura o que se pensa "estabilizado" (PÊCHEUX, 2009), possibilitando a polissemia.

Diante disso, faremos a seguir uma discussão acerca do discurso sobre o que é literatura, pois acreditamos que é um modo de observarmos o funcionamento da política literária para, assim, refletirmos sobre a legitimação e/ou interdição da autoria de mulheres negras e suas obras, em especial, sobre Carolina Maria de Jesus.

\subsection{O que é Literatura?}

"Escolher escrever é rejeitar o silêncio" (Chimamanda Ngozi Adichie).

Ao defendermos que nenhuma obra literária está fadada ao fechamento dos sentidos que, a nosso ver, é este o modo como a escola trabalha as obras literárias que seleciona para o seu 
currículo, compreendemos que a literatura não é um campo preestabelecido e fixo.

Esse modo fixo com que a escola trabalha é fácil de ser percebido: o sujeito-professor tende a trabalhar certas autoras e autores e suas obras acopladas a escolas literárias, isto é, uma "estilística" e/ou "história" que tenta emoldurar sentidos que podem ser lidos, repassados, memorizados, reproduzidos nas avaliações escolares, ou seja, a literatura se reduz a conteúdos preestabelecidos sobre o que devem os sujeitos-alunos aprender (saber) acerca de uma obra literária e o seu autor.

Há um discurso - que a escola também sustenta - a respeito das obras literárias sobre o seu valor, isto é, separando quais são boas e quais não são. Na escola isso se dá toda vez que o sujeito-professor, voz de autoridade, discursiviza aos sujeitos-alunos qual obra tem qualidade e qual não tem, conforme podemos observar na citação:

\begin{abstract}
Além de óbvia intenção didática das informações contidas em uma novela de aventuras, nota-se que, para o jovem, o descortino de um mundo desconhecido é uma instigação ao imaginário, é uma mola propulsora à construção do seu futuro. Para o adulto que lê um romance trivial, o efeito é outro. Pelo processo de identificação leitor/herói, (...) o leitor se liberta por algumas horas de seu insípido mundo rotineiro e vive emoções intensas num mundo extraordinário de beleza e luxo a que nunca terá acesso de fato (...). A resposta ativa da postura crítica ou da criação imaginativa cede lugar à acomodação, à passividade, ao conformismo. A abundância de edições baratas (Bianca, Júlia, Sabrina, etc) desses entorpecentes ficcionais (grifo nosso) é reveladora do tipo de público a que se dirige. (SILVA, 2013, p. 37).
\end{abstract}

Como podemos observar, há um discurso, inclusive difundido na academia, que pressupõe a existência de uma literatura com "l" minúsculo - os "entorpecentes ficcionais" e outra com "L" maiúsculo - isto é, a "Grande" literatura que possibilita a "postura crítica ou da criação imaginativa".

Ao se pensar no sujeito-leitor criança, as obras literárias "entorpecentes" podem circular e ser acessadas, visto que estão atreladas ao "didático", a uma "investigação da imaginação"; todavia, quando se pensa no sujeito-leitor adulto espera-se que esse sujeito já tenha "ultrapassado" as obras "entorpecentes" e tenha deslocado de uma certa "acomodação", já que o leitor (imaginário) não pode se "revelar" pertencente a um determinado "tipo de público", ou seja, aquele que ainda não atingiu a duvidosa "maturidade leitora", sinônimo de eficácia.

É por meio de discursos como o da citação acima que o sujeito-professor tende a sustentar o seu discurso em sala de aula, discurso esse que produz um cenário escolar em que 
as leituras dos sujeitos-alunos tendem a ser deslegitimadas, porque nem sempre aquilo que o sujeito-aluno gosta de ler é considerado obras de literatura com "L" maiúsculo.

Há uma ideologia dominante que funciona para a difamação das obras que circulam nas bancas de jornais (Bianca, Júlia, etc); no entanto, essa mesma difamação não ocorre com as obras que são abordadas nos períodos literários consagrados no chão da escola, cujos representantes são autores e obras consagrados.

O grande problema é que muitos sujeitos-professores acreditam no discurso segundo o qual existe uma literatura de mais qualidade do que outras e reproduzem esse discurso na escola aos sujeitos-alunos quando, na verdade, a muitos autores e autoras consagrados nem mesmo o sujeito-professor teve acesso.

O que temos é uma reprodução sobre o discurso de qualidade. Essa ilusão de qualidade está diretamente ligada à questão de autoria, em especial, à questão do nome do autor (FOUCAULT, 2011) e do que se pensa ser uma obra literária (discussão que ainda faremos ao tratarmos do mercado editorial).

Por outro lado, não estamos defendendo a falsa democratização da cultura literária que reduz a vida cultural por meio de "certa facilitação formal e superficialidade de conteúdo dos produtos culturais, que se justificam em razão do propósito cívico de chegar à maioria" (VARGAS LLOSA, 2013, p.31), fazendo com que se tenha um desaparecimento da chamada "alta" cultura, em virtude dos desafios que certos modos do fazer artístico de determinados artistas, neste caso, de escritoras e escritoras, coloca-nos:

\footnotetext{
Por isso, não é de estranhar que a literatura mais representativa de nossa época seja a literatura light, leve, ligeira, fácil, uma literatura que sem o menor rubor se propõe, acima de tudo e sobretudo (e quase exclusivamente), divertir (...) Se em nossa época raramente são apreendidas aventuras literárias tão ousadas como as de Joyce, Virginia Woolf, Rilke ou Borges, isso não se deve apenas aos escritores; deve-se também ao fato de que a cultura em que vivemos imersos não propicia, ao contrário desencoraja, esses esforços denodados que culminam em obras que exigem do leitor uma concentração intelectual quase tão intensa quanto a que as possibilitou. Os leitores de hoje querem livros fáceis, que os distraiam, e essa demanda exerce uma pressão que se transforma em poderoso incentivo para os criadores. (VARGAS LLOSA, 2013, p. 32).
}

A nossa defesa é pela literatura no sentido plural, em que certas obras sempre terão desafios de leitura em maiores ou em menores graus de complexidade. Diante disso, a questão que se coloca é: a escola está apta para ensinar, nessas circunstâncias? A nosso ver, não, pois se ainda circula um discurso construído por professores e gestão escolar que deslegitima a 
capacidade dos estudantes ao dizer que certas obras e autores são "difíceis demais" para a "clientela" - sentido pejorativo muito recorrente para fazer referência aos alunos, o qual produz o efeito de escola como mercadoria - e, por essa razão, a instituição escolar não abre espaço para a ampla literatura, por sua vez, não democratiza o acesso ao conhecimento.

De acordo com a tipologia discursiva de Orlandi (2012), se a escola trabalhar pelo discurso autoritário, o sujeito-professor tende a não considerar a leitura que os sujeitos-alunos trazem para dentro desse espaço, visto que se interditam as literaturas com "l", isto é, trabalha-se somente em prol da paráfrase e da fôrma-leitor (PACÍFICO, 2002) da considerada Literatura, com "L".

Aliás, é pertinente destacar que há uma formação discursiva que produz o discurso que os estudantes não leem, quando na verdade o que ocorre é que a leitura que eles fazem não é a considerada pela escola.

\footnotetext{
O frequente desânimo e a falta de motivação dos alunos e dos professores abrem o capítulo de um longo seriado, em que há a domesticação de alguns sentidos aceitos, legitimados, tidos como corretos e reconhecidos como merecedores de credibilidade (...) a leitura é vitimada pela burocratização do texto, recortando em regras e fatiado em normas, utilizado apenas como modelo a ser copiado, "interpretado" pelo conteúdo dado. (ROMÃO; PACÍFICO, 2006, p.17).
}

A escola tem de ser o espaço da troca e não da imposição da leitura, em que sujeitosalunos e sujeitos-professores estão autorizados a levarem para essa instituição suas leituras, suas obras literárias preferidas, ou seja, uma instalação da discursividade literária de modo democrático e, sobretudo, prazeroso.

Isso não equivale a dizer que cabe à escola trabalhar apenas as obras literárias de cunho e gosto pessoal dos sujeitos que ocupam determinadas posições nessa instituição, pelo contrário, não se trata da valorização de uma literatura, mas, conforme já argumentamos, das literaturas, como Direito Humano (CANDIDO, 1988).

É pelo discurso polêmico que as obras literárias que circulam na escola podem ser discursivizadas, em que a indagação “o que é literatura?” pode ser pensada, (re)formulada, argumentada, a partir de determinadas condições de produção.

Nesse sentido, não se procura fechar os sentidos sobre o que faz uma obra ser literatura ou não, antes, abre-se a possibilidade da disputa; não se interdita obras literárias, antes, selecionam-se obras que, em determinadas condições de produção, "gritam” para serem lidas e trabalhadas nessa agência de letramento, a partir de um trabalho que leve em consideração 
os aspectos sócio-histórico-ideológicos das obras literárias.

A literatura é literatura, isto é, "aquilo que as autoridades (os professores, os editores) incluem na literatura" (COMPAGNON, 2010, p. 45), diríamos mais, não são apenas os sujeitos de autoridade que disputam os sentidos sobre o que é literatura (mesmo sabendo que são os sujeitos que tendem a ser mais "respeitados"), mas todos os sujeitos que se afetam pelas literaturas têm o direito de dizer o que é literatura; desse modo, ancorados na $A D$, argumentamos que literatura é um efeito de sentido que emerge da Literatura e que se historiciza como literário.

É possível encontrar na escola sujeitos que se autorizam a escrever, nas famílias dos sujeitos-alunos, na vizinhança onde a escola está inserida, ou seja, no próprio chão da escola e em seu entorno é possível encontrar sujeitos-autores de literatura que podem e devem estar no cotidiano do currículo escolar, afinal, é preciso romper com uma formação imaginária que prega um ideal de autor que é sustentado por uma concepção de literatura fechada e cristalizada.

Eagleton (2006), filósofo e crítico literário britânico, ao tentar responder à questão do que é literatura, permite que percebamos os efeitos de sentidos construídos ao longo do tempo, isto é, os efeitos historicizados sobre o que pode vir a ser literatura, ainda mais, o efeito político dessas definições materializadas nesses discursos.

Uma definição do que seja literatura é o discurso que diz que a literatura é uma "escrita imaginativa", no sentido de ficção, daquilo que não é verídico; todavia, assim como argumenta o autor, esse discurso não se sustenta. É só observarmos qual texto é selecionado na escola para trabalhar o que designam de "literatura de informação e/ou Quinhentista brasileira" - a carta de achamento de Pero Vaz de Caminha - que não se sustenta na redução desse discurso de escrita ficcional e "criativa".

Se a literatura estiver atrelada a essa concepção, segundo Eagleton, convém dizer o mesmo que a história, a filosofia e as ciências naturais são destituídas de imaginação, portanto, como podemos notar, não se levam em conta o direcionamento, isto é, o modo como uma leitura é trabalhada, tampouco as condições de produção em que a leitura acontece.

Uma outra concepção vai definir a literatura não pelo ficcional ou "imaginativo", mas “porque emprega a linguagem de forma peculiar" (EAGLETON, 2006, p. 3). É como se as obras literárias tivessem uma organização particular da linguagem, uma espécie de "violência linguística", em que a literatura é uma forma "especial" de linguagem em contraste com a 
linguagem "comum" do dia a dia.

Essa concepção de literatura é apresentado pelos formalistas russos que tiveram suas ideias difundidas durante a década de 1920, entre os quais Vítor Sklovski, Roman Jakobson, OsipBrik, YuryTynyanov, Boris Eichenbaum e Boris Tomashevski. Para esses formalistas a obra literária era "um fato material, cujo funcionamento podia ser analisado mais ou menos como se examina uma máquina" (idem, 2006, p. 4), é como se o texto literário fosse um corpo-textual estranho por desviar-se de uma suposta norma linguística:

Eles não queriam definir a "literatura", mas a "literaturidade" - os usos especiais da
linguagem -, que não apenas podiam ser encontrados em "textos literários", mas
também em muitas outras circunstâncias exteriores a eles (...) os formalistas
achavam que a essência do literário era o "tornar estranho". Eles apenas
relativizavam esse uso da linguagem, vendo-o como uma questão de contraste entre
um tipo de discurso e outro (...). (EAGLETON, 2006, p. 09).

Na concepção literária dos formalistas russos, sustentada por uma visão positivista de língua e linguagem, todo texto literário se resume a uma função, isto é, a função poética, o que leva a compreender que toda literatura é (ou tem de ser) poética, lida segundo a ilusão de transparência da linguagem; no entanto, como associar essa visão às obras de Carolina Maria de Jesus? Será que, devido à "linguagem estranha" que as obras de Carolina são (ou não) consideradas literatura? A nosso ver, quando pensamos na escola, o estranhamento literário tende mais a afastar os sujeitos-alunos do que trazê-los para o universo literário.

Os formalistas russos procuram separar a "linguagem literária" da "linguagem cotidiana" ao trabalhar com a ideia de literariedade como propriedade distintiva de um texto literário. É como se a literatura renovasse a sensibilidade linguística dos leitores por meio de procedimentos que desarranjam as formas habituais e automáticas da sua percepção (COMPAGNON, 2010, p. 41), aquilo que Jakobson (1935) explicará como "efeito de desfamiliarização", isto é, enfatiza-se a mensagem, numa visão positivista de linguagem, sustentada no que chamavam de "licença poética", portanto, a literatura se caracterizaria por uma determinada função - a função poética - em que o emissor usa recursos criativos para a elaboração da mensagem, para tal, utiliza as figuras de linguagem, metáforas, musicalidade, sentido conotativo etc.

No entanto, Compagnon (2010, p. 43) provocando a visão sobre literatura dos formalistas russos vai dizer que a publicidade seria o "máximo da literatura", já que é carregada dos "traços literários" da função poética, mesmo que menos "densos" que nas obras literárias; 
todavia, não é considerada literatura, o autor, então, questiona: "seria, pois, toda a literatura o que a literalidade dos formalistas caracterizou, ou somente um certo tipo de literatura; a literatura por excelência, de seu ponto de vista?" (idem, 2010, p. 43), até porque a "literatura confirma um consenso, mas produz também a dissensão, o novo, a ruptura" (ibidem, 2010, p. 36), argumento com o qual concordamos.

Como podemos observar, a busca por uma "essência da literatura" não se confirma, pois há determinados gêneros discursivos, como as propagandas, que furam a ideia da literariedade dos formalistas russos, simplesmente porque há "traços" nas obras literárias que são possíveis de serem encontradas nas propagandas, isto é, pode-se reconhecer facilmente a "função poética" em um anúncio, deste modo, não é uma determinada estrutura textual que garantirá dizer que determinado texto é ou não literatura, mas, compreender que a definição do que é literatura é político, diríamos um "campo minado" de disputa discursiva: a literatura é sempre literatura quando alguém discursiviza (se autoriza) a dizer que é literatura, portanto, discurso que passa a ser legítimo e/ou interditado dependendo de quem enuncia.

Opondo-nos a essa concepção dos formalistas russos em relação à literatura, concordamos com Eagleton (2006, p. 12) quando diz que a literatura não pode ser definida "objetivamente", mas que depende da "maneira pela qual alguém resolver ler, e não da natureza daquilo que é lido", afinal, não existe uma "essência" da literatura, mas uma definição do que é o "universo literário" a partir de "julgamentos de valor" que têm a ver, sem dúvida, com a concepção que se tem de literatura, língua e linguagem, em que esses "juízos de valor" são sempre historicamente, socialmente e ideologicamente definidos, portanto, são definições mutantes visto que o sentido sempre pode vir a ser outro (ORLANDI, 2012) e disputado, a partir de determinadas condições de produção.

Todos esses apontamentos nos levam a pensar nas obras de Carolina Maria de Jesus que, nessa concepção dos formalistas russos, possivelmente não seria reconhecida como literatura, até porque nessa teoria se concebe o sujeito empírico e não como a $\mathrm{AD}$ o entende: o autor em uma posição discursiva.

As obras de Carolina seriam classificadas, provavelmente, como meros diários - relatos do cotidiano de uma mulher e não como literatura. Por isso, é importante marcarmos o referencial teórico que sustenta esta dissertação que, por sua vez, sustenta o modo como concebemos a literatura.

Ao concebermos que a relação dos sentidos com a interpretação é um processo sem fim, o 
objetivo da $\mathrm{AD}$, conforme estamos demostrando, é compreender o funcionamento discursivo, isto é, como um texto produz sentidos (ORLANDI, 2012), em que o corpus, segundo a AD é o texto, no sentido não textual, mas discursivo, que leva em conta as condições de produção, deste modo, as palavras são interpretadas de acordo com as formações discursivas e com os processos de interpelação sofridos pelo sujeito.

Deste modo, tomamos o texto em sua materialidade linguística, em que o discurso é visto como estrutura e acontecimento e, uma vez que a língua é opaca, ela materializa-se e apresenta as clivagens do sujeito que se imagina como o dono dos sentidos; no entanto, o sujeito é interpelado ideologicamente, portanto, um sujeito assujeitado a condições de produção demarcadas no discurso e dentro de cada Formação Discursiva, isto é, "aquilo que numa formação ideológica dada, isto é, determinada pelo estado da luta de classes, determina o que pode e deve ser dito" (PÊCHEUX, 2014, p. 160).

Nessa perspectiva teórica não há "linguagem poética" que sustentaria a função poética da literatura de acordo com os formalistas russos, pois o que há é um processo geral de linguagem, funcionando, nos seus usos político e literário "jogando nas latitudes” que a língua oferece (PÊCHEUX, 2015, p. 105).

É pelas Formações Ideológicas que se estabelecem os sentidos das palavras a partir de um jogo de formações imaginárias (posições ideológicas). Desse modo, para a $\mathrm{AD}$, não há transparência da linguagem, já que as palavras e expressões "mudam de sentido segundo as posições sustentadas por aqueles que as empregam, o que quer dizer que elas adquirem seu sentido em referência a essas posições, isto é, em referência às formações ideológicas" (PÊCHEUX, 2014, p. 160). Nessa direção, o texto literário:

(...) na condição de texto, possui sua historicidade e sua história. Seus sentidos só
lhes são posíveis em uma conjuntura dada quando há o funcionamento do discurso
na língua, em condições de produção também dadas. Portanto, antes, durante e
depois da superfície linguística, há a historicidade. Esta sim é que oferece aos
elementos linguísticos, envolvendo-os e constituindo-os, sua capacidade de ser
texto. Interessa, portanto, perceber o processo de produção deste(s) ou daquele(s)
sentido(s) de um texto (aqui, como um texto literário funciona) e isto se dá a partir
do momento em que se passa a considerar as formações discursivas e as posições do
sujeito no discurso, bem como o trabalho da memória e a interpretação enquanto
prática discursiva. (HENGE, 2015, p. 3).

A literatura, na perspectiva discursiva, diferentemente das teorias positivistas, é um acontecimento de linguagem, ou seja, as produções literárias são vistas como discursos que permitem gestos de interpretação, portanto, a busca é pela compreensão de elementos que o 
levaram a ser interpretado de um certo modo e não de outro; nesse sentido, é preciso considerar a literatura como uma escritura que é produzida a partir de determinadas condições de produção, deste modo, possui uma materialidade histórico-ideológica. Por condições de produção deve-se compreender o contexto imediato (circunstâncias de enunciação) e o contexto amplo (sócio-histórico-ideológico) que afetam o modo como os sentidos são produzidos.

Essa concepção de literatura na perspectiva discursiva - produção literária como escritura que imprime uma memória na língua - faz com que o trabalho da escola desloque-se do modo como os livros didáticos trabalham: linearização, características das escolas literárias e dos autores, estilo de escrita etc.

Como podemos observar, refletir sobre a literatura a partir da $\mathrm{AD}$ é não reduzir o trabalho a partir da contextualização histórica, difundida nas disciplinas acadêmicas de História da Literatura, muito menos reduzi-la ao estudo linguístico ou estilístico, mas, sobretudo é compreender a obra literária como discurso em que, por meio de gestos de leitura, trabalha-se os efeitos de sentido a partir de determinadas condições de produção.

É compreender que quando a leitura se realiza é nesse processo que se configura o espaço da discursividade em que se instaura um modo de significação possível, sendo assim, a leitura é o "momento crítico da constituição do texto, o momento privilegiado do processo de interação verbal, uma vez que é nele que se desencadeia o processo de significação" (ORLANDI, 2012, p. 49).

Para Bragatto Filho (1995) o texto literário se opõe ao texto funcional, pois o texto literário tem por base uma característica inicial: o fato de não ter uma função preestabelecida, diferente do texto funcional que é essencialmente pragmático.

Concordamos com o autor, ainda mais quando ele argumenta que o texto literário não é utilitário, uma vez que o leitor, ao dialogar com o mesmo, pode atribuir diferentes funções e finalidades, diríamos, que o leitor está autorizado a tecer seus gestos de leitura. Essa atribuição do leitor só ocorre, conforme estamos argumentando, quando a escola deixa de trabalhar pautada no discurso de tipo autoritário e passa para o de tipo polêmico (ORLANDI, 2012), em que os efeitos de sentidos podem e são disputados.

O texto, segundo o autor, compara-se a um tecido, em que - texto e tecido - são entrelaçamentos em cadeias de fios discursivos, tornando-se fios de encadeamento sintáticosemântico uma dimensão discursiva-ideológica. 
Esses textos-tecidos, por sua vez, possuem lacunas, "espaços vazados" a serem preenchidos pelo leitor no momento da leitura; sendo assim, nenhuma obra literária está pronta e acabada, mas possui espaços abertos a gestos de leitura, a partir de efeitos de sentidos desencadeados pelo trabalho estético do autor e da atuação do leitor em relação a sua atribuição de sentidos ao texto literário, assim, o texto é dotado de literariedade:

(...) abre possibilidades aos leitores de não terem apenas pensamentos ou opiniões convergentes, mas sobretudo divergentes, geradores de uma multiplicidade de ideias e interpretações, o que certamente instaura a riqueza de questionamentos, a polêmica. (BRAGATTO FILHO, 1995, p. 18).

Uma obra literária ao ser interpretada, avaliada, legitimada ou interditada faz-se de acordo com essas considerações que são embasadas em um conceito sobre literatura; nesse sentido, a literatura de autoria de mulheres negras joga o jogo da política literária na busca de garantir o seu direito de autoria e, com isso, provoca questões que, por serem ausentes, fazemse urgentes (GOMES, 2017) como a "incorporação dos elementos culturais de origem africana no que diz respeito a temas e formas, traços de uma subjetividade coletiva (...) mudanças de paradigma crítico-literário (...)” (CUTI, 2010, p. 11).

Importa na política literária o discurso do que se quer legítimo na literatura, a fim de interditar o que se quer silenciado, conforme Orlandi (2012) entende o silêncio da censura, o do não poder dizer.

Discutir a literatura produzida por mulheres negras é ter que lidar com essa política literária, ora rompendo conceitos cristalizados e antidemocráticos, ora (re)formulando novos modos de discurso para aquilo que se considera literatura.

O texto literário provoca a instauração do discurso polêmico, causando desestabilização e desconforto, isto é, nutre a tradição (paráfrase), mas também traz o novo, a ruptura, a possibilidade de o sentido ser sempre outro (polissemia), por meio do seu potencial discursivo-estético.

A política literária ajuda-nos a perceber os movimentos dos sentidos, sobretudo, quais são evocados e quais são silenciados, para investigarmos quais valores construídos socialmente, historicamente e ideologicamente são colocados em cena para se valorar uma obra literária e quem pode ser autor de literatura, quais obras são dignas de fazer parte da lista dos clássicos, isto é, dos cânones, questões que, dependendo do conceito que se tem de literatura, levarão a formulações de diferentes respostas. 
É por isso que, dependendo de qual concepção de literatura se defende, Carolina e suas obras terão ou não valor, o que permite também dizer que Carolina será ou não considerada uma autora, por sua vez, se sua obra é ou não “digna” de ser considerada um clássico. O efeito disso será a legitimação ou a interdição dessa obra e desse autor.

Por isso, defendemos que a literatura é um campo de conhecimento do humano e do funcionamento da linguagem, experiência singular, em que o texto, caracterizado pela sua incompletude, gera efeitos de sentidos provocados no leitor por meio de seus gestos de interpretação, dos preenchimentos das lacunas deixadas pelo autor, os "espaços vazados" (BRAGATTO FILHO, 1995) que um texto literário pode trazer.

Como salientou Candido (1988) a literatura não serve para nada e, por isso mesmo, "serve" tanto. Esse dizer mostra que a literatura não pode ser vista pelo viés utilitarista, visto que a sua função é a da humanização, portanto, as literaturas das margens, como a de Carolina Maria de Jesus, precisam ganhar mais visibilidade social, por contribuírem com narrativas e discursos que engendram outras geografias literárias, que não podem mais ser silenciados, negados, interditados, visto que é um direito.

E também por tratar de uma literatura que rompe as "barreiras" do preconceito e da discriminação, seja pela linguagem, seja pelas suas pluralidades temáticas, permitindo que o campo político da literatura continue em expansão, com abertura ao "novo", isto é, polissêmico e de acesso democrático, procurando romper com a "lógica" do legítimo na literatura.

A partir da discussão trazida sobre o que é literatura e a impossibilidade de um conceito "fixo" que dê conta dessa questão, a seguir trataremos o discurso dos clássicos, os considerados "imortais" da literatura, que também contribuem com o funcionamento da política literária, impedindo que a autoria de mulheres negras - literatura das margens - ganhe esse estatuto.

\subsection{O que é um clássico da literatura?}

\footnotetext{
"Eu canto aos Palmares/Sem inveja de Virgílio de Homero/E de Camões/ Porque o meu canto/É grito de uma raça/ Em plena luta pela liberdade!'. (Solano Trindade).
}

A partir da discussão anterior sobre a concepção de literatura, outro modo de também 
refletirmos sobre a legitimação e a interdição de uma obra literária é o discurso acerca do que é uma obra clássica literária. Isso porque a ideia de clássico se atrela à legitimação de um autor e sua obra, visto que sentencia uma afirmação do que pode ser considerado uma obra literária clássica, sinônimo de qualidade, por sua vez, autorizada a fazer parte do chamado cânone.

Calvino (1993) trata dos clássicos em um texto intitulado Por que ler os clássicos, na obra de mesmo nome. $\mathrm{O}$ autor tenta definir os clássicos, inicialmente, como "aqueles livros dos quais, em geral, ouve-se dizer: Estou relendo ... e nunca: Estou lendo (...)” (idem, p. 9), no entanto, é uma definição que reverbera sentidos que excluem os jovens, visto que ainda não se encontrariam na "fase" das releituras, para isso, o autor elabora outra definição: "Dizem-se clássicos aqueles livros que constituem uma riqueza para quem os tenha lido e amado; mas constituem uma riqueza não menor para quem se reserva a sorte de lê-las pela primeira vez nas melhores condições para apreciá-las" (ibidem, p.10); no entanto, mais uma vez o discurso sobre clássico feita pelo autor não consegue dar conta da primeira definição, já que a leitura pela primeira vez de uma obra pode ser feita de modo pouco atenta pelo sujeito-leitor, sem “apreciação" e, até mesmo, ser esquecida ao longo do tempo.

Diante das duas definições anteriores sobre o que é um clássico, o autor propõe mais uma: "Os clássicos são livros que exercem uma influência particular quando se impõem como inesquecíveis e também quando se ocultam nas dobras da memória, mimetizando-se como inconsciente coletivo ou individual" (ibidem, p.10).

Nessa definição, o autor produz um efeito de sentido de valorização da literatura ao dizer que pode "exercer uma influência particular" e se "imporem como inesquecíveis", argumento com o qual concordamos; porém, ao dizer da "mimetização no inconsciente coletivo e individual", produz um sentido de que nem toda obra literária é um clássico porque não conseguiria produzir esse efeito: a de que "Toda releitura de um clássico é uma leitura de descoberta como a primeira" e "Toda primeira leitura de um clássico é na realidade uma releitura"(ibidem, p.11).

Dessa forma: "Um clássico é um livro que nunca terminou de dizer aquilo que tinha para dizer" (ibidem, p.12). Como é possível notar, ao buscar uma resposta para a sua inquietação “por que ler os clássicos?”, o autor acaba por deslizar nos fios discursivos que não se fecham, já que a cada tentativa de definição outra é dada a fim de "completar" os furos e aberturas das definições anteriores. 
Ainda no decorrer da leitura do texto de Calvino, o autor critica as escolas e as universidades que utilizam comentadores de obras literárias sem garantir de fato o acesso à literatura, deste modo, o sujeito-leitor tem acesso a uma obra literária pelo discurso do outro e não por si mesmo. Para o autor, o sujeito-leitor deve relacionar-se com a obra literária de modo "desinteressado", isto é, não de modo imposto e obrigatório, que é o modo como geralmente a escola trabalha.

Concordamos com o autor e defendemos que o acesso à literatura garantida pela escola deve partir de um trabalho que leve o sujeito-aluno a ocupar a função-leitor (PACÍFICO, 2012) e não um trabalho que impeça o sujeito de tecer seus sentidos acerca das obras que lê, portanto, os comentadores de obras devem ser vistos como sujeitos-leitores que fizeram suas leituras de uma obra literária e materializaram determinados sentidos em seus textos críticos; todavia, não podem ser vistos como os "donos dos sentidos", mas como sujeitos que contribuem para a polissemia dessas leituras por meio da prática do discurso polêmico (ORLANDI, 2012).

O autor ainda diz que "um clássico é um livro que vem antes de outros clássicos; mas quem leu antes os outros e depois lê aquele, reconhece logo o seu lugar na genealogia" (ibidem, p.13) e é nessa conceituação de clássico que queremos focar a questão da política literária em funcionamento.

O autor, ao dizer sobre a "genealogia das obras clássicas", sugere-nos compreender um clássico como uma obra literária antiga, o que nos leva a indagar: clássico são apenas as obras literárias de séculos passados? Seriam essas obras do passado as legitimadas? Ao dizer isso, temos um efeito de interdição das obras contemporâneas em que "é clássico aquilo que persiste como rumor mesmo onde predomina a atualidade mais incompatível” (ibidem, p.14), portanto, uma obra só se legitimaria como clássico se for antiga, mas, também capaz de "conversar" com a atualidade. Temos, sobretudo, um modo de "mumificação" das obras literárias em que a legitimação do clássico se dá por um longo processo sócio-históricoideológico que, a nosso ver, o autor não desenvolve sobre essa questão, pois apenas argumenta que "para poder ler os clássicos, temos de definir "de onde" eles estão sendo lidos, caso contrário tanto o livro quanto o leitor se perdem numa nuvem atemporal" (ibidem, p.14), não problematizando esse "de onde", tão importante para a discussão do político na literatura.

Para nós, analistas de discurso, a naturalização do uso "de onde" torna-se um ponto fundamental, já que as formações imaginárias sustentadas em formações discursivas e 
ideológicas, tendem a ditar o legítimo do literário a partir desse "lugar" de onde enuncia.

Um "lugar" de enunciação em que podemos observar o discurso sobre o que pode ser considerado uma obra literária clássica e o que não pode é o da universidade, da escola e das instituições que promovem as listas de obras selecionadas para o vestibular. Por se constituírem como vozes de autoridade na sociedade, as obras literárias discursivizadas por esses "lugares" legitimam a obra que merece fazer parte do cânone.

Calvino termina sua argumentação dizendo que a presença dos clássicos é um "reboar distante", já que as instituições escolares e as mídias de comunicação, como a televisão, impedem a presença dos clássicos na vida das pessoas. Para o autor, os clássicos ajudam a entender "quem somos" e por isso, não devem ser lidos pelo motivo de servirem para qualquer coisa, mas, porque "lê-los é melhor que não lê-los", assim:

E se alguém objetar que não vale a pena tanto esforço, citarei Cioran (não um clássico, pelo menos por enquanto, mas um pensador contemporâneo que só agora começa a ser traduzido na Itália): "Enquanto era preparada a cicuta, Sócrates estava aprendendo uma ária com a flauta. 'Para que lhe servirá?', perguntaram-lhe. 'Para aprender esta ária antes de morrer. (CALVINO, 1993, p.16).

Se a literatura não tem propriamente uma função, o "aprender", isto é, ter acesso à literatura é muito melhor do que não ter, argumento com o qual concordamos; no entanto, o conceito de clássico de Calvino é uma empreitada repleta de fios discursivos que levam a outros, em que as rachaduras discursivas, os furos, a impossibilidade do fechamento de um sentido para o que seja clássico fica sempre em aberto. Feito isso, as formações discursivas apoiadas em formações ideológicas e imaginárias sobre o conceito de clássico ao direcionar um caminho de conceituação, outros se abrem, visto que todo discurso vem sempre apoiado em um interdiscurso.

Compagnon (2010, p. 221) argumenta que o público leitor espera que o crítico literário separe o "joio do trigo" para que se tenha uma fixação do cânone, em que essa crítica deve ser uma "avaliação argumentada"; no entanto, toda crítica corre o risco de não ter um fundamento objetivo, já que o estudo literário está atrelado a um sistema de preferências. Deste modo, no século XX, a necessidade de objetividade e de cientificidade vai ser questionada:

O tema "valor", ao lado da questão da subjetividade do julgamento, comporta ainda a questão do cânone, ou dos clássicos, como se diz de preferência em francês, e da formação desse cânone, de sua autoridade - sobretudo escolar - de sua contestação, de sua revisão. Em grego, o cânone era a regra, um modelo, uma norma representada 
por uma obra a ser imitada. Na Igreja, o cânone foi a lista, mais ou menos longa, dos livros reconhecidos como inspiradores e dignos de autoridade. $\mathrm{O}$ cânone importou o modelo teológico para a literatura do século XIX, época da ascensão dos nacionalismos, quando os grandes escritores se tornaram os heróis do espírito das nações. Um cânone é, pois, nacional (como uma história da literatura), ele promove os clássicos nacionais ao nível dos gregos e dos latinos, compõe um firmamento diante do qual a questão da admiração individual não se coloca mais: seus monumentos formam um patrimônio, uma memória coletiva. (COMPAGNON, 2010, p. 222).

Apesar da longa citação, fizemos questão de trazê-la para esse texto porque entendemos que o autor permite uma reflexão acerca dos sentidos sobre o clássico e o cânone. É possível observar que clássico é sempre um clássico a partir de uma voz de autoridade que legitima uma obra literária a essa categoria, tendo a questão problemática de valor no centro da discussão, por exemplo, a do valor grego em que clássico era uma obra "a ser imitada", isto é, vista como referência.

Uma obra literária para ser clássica e ser colocada na lista do cânone depende de uma historicidade para se transformar em um patrimônio cultural. A partir disso, o interdiscurso (já-lá) permite a atualização da memória discursiva e a materialização no intradiscurso em que a definição do que é clássico é pendulada por uma política literária que diz o que tem valor e o que não tem.

Quando alguém diz que determinada obra e autor são um clássico da literatura embasa seu discurso em uma voz de autoridade, por meio de um discurso que já funcionou antes, ou é o sujeito (professor, crítico literário, teórico da literatura, entre outros) autorizado a dar esse veredito, o que indica que não é qualquer sujeito que está autorizado a dizer nem o que é literatura, muito menos quais obras devem ser consideradas clássicas.

A questão da voz de autoridade é observada dentro da escola quando o sujeito-aluno é desautorizado pelo sujeito-professor a dizer que suas leituras pessoais são clássicas e, como muitas vezes a escola é o espaço do discurso autoritário, não é permitida uma reflexão sobre essa questão, em que clássico será sempre o que o sujeito-professor diz que é, sustentado em um dizer que já foi dito antes: "Dom Quixote, de Miguel de Cervantes, é um verdadeiro clássico da literatura".

$\mathrm{Na}$ escola, essa reflexão sobre o que faz um livro de literatura ser concebido como uma obra literária clássica pertencente ao cânone tem pouco espaço, já que o livro didático determina, como voz autorizada e de autoridade, quais obras e autores/autoras podem fazer parte dessa lista, e o sujeito-professor, muitas vezes, legitima o discurso do livro didático sem 
questionar o silenciamento que é feito em relação a outras autoras e autores e suas obras.

É por isso que encontramos muitos sujeitos-alunos comentando, por exemplo, a respeito da obra Dom Casmurro (1974), de Machado de Assis, suscitando a célebre questão: Capitu traiu ou não traiu Bentinho? Mesmo sem ter tido acesso à obra, porque é um dizer sustentado em uma paráfrase legitimada, como se a obra se reduzisse a essa única trama, fechando outros sentidos e indagações, por exemplo, por que a dúvida da traição conjugal é direcionada a uma mulher? Questão pertinente na contemporaneidade devido aos movimentos feministas que questionam o patriarcado, todavia, a escola trabalha na paráfrase.

Se o discurso sobre o clássico abre a possibilidade da polissemia, dos múltiplos sentidos, da capacidade que a literatura tem de nunca fechar os sentidos; por outro lado, a ideia de clássico, legitimado por alguém autorizado, tenta controlar a polissemia, fazendo com que a parafrasagem apareça controlando o que pode e deve ser dito.

É por isso que concordamos com Compagnon (2010, p. 226) em que "as obras não têm valor em si mesmas" visto que, de um lado temos os defensores tradicionais do cânone e de outro os teóricos que contestam essa validade. No meio, um certo número de posições medianas, frágeis, que procuram manter uma certa legitimidade de valor que, segundo o autor, depois do Iluminismo, uma vez abaladas a tradição e a autoridade, dizer o que é um clássico e saber identificar quais obras têm o direito de fazer parte do cânone tornou-se uma tarefa complexa e difícil, diríamos, de poder.

É possível dizer que o discurso sobre o clássico está muito ligado à ideia de algo que "venceu a prova do tempo"; todavia, o autor questiona ao argumentar que nenhum juízo de valor está garantido, já que a legitimação de uma obra pode ocorrer por um efeito de "modismo", a saber, "eu gosto porque me disseram que é para gostar", em que, Compagnon (2010, p. 249) salienta:

(...) O cânone não é fixo, mas também não é aleatório e, sobretudo, não se move constantemente. É uma classificação relativamente estável, e, se os clássicos mudam, é à margem, através de um jogo, analisável, entre o centro e a periferia. Há entradas e saídas, mas elas não são tão numerosas assim, nem completamente imprevisíveis. É verdade que o fim do século XX é uma época liberal, em que tudo pode ser reavaliado (...), mas a bolsa de valores literários não joga ioiô.

É esse jogo entre "o centro e a periferia" que atua a política literária. Como bem disse o autor, o valor de uma obra literária não joga "ioiô", antes, disputa o jogo político do literário e é isso que nos interessa observar nesta dissertação, pois é desse modo que compreendemos as 
obras de Carolina Maria de Jesus que, em 1960, teve seu apogeu, tornando-se um livro ovacionado pela crítica da época por causa de seu conteúdo “inédito" e, também, de uma estranha-novidade, sobretudo, por ter sido escrito por uma mulher, negra, periférica.

Durante muito tempo a crítica chegou a cogitar que a escrita dos diários de Carolina teriam sido do jornalista Audálio Dantas, que descobriu os escritos de Carolina ao fazer uma matéria jornalística onde morava a autora.

Essa situação aborda o quanto a escrita de autoria de mulheres negras incomoda e é vista como “(...) não dignas de reflexões e análises críticas sofisticadas” (hooks, 2019, p. 32), pois, segundo essa autora, a heterogeneidade e subjetividade das vidas dos sujeitos-negros nunca importaram, visto que só ganham notoriedade a partir de uma narrativa discursiva que os coloquem na subalternidade, sustentados por um “(...) olhar que procura dominar, subjugar e colonizar" (hooks, 2019, p. 41).

Ainda mais quando temos uma autora como Carolina que "encara o desafio de falar aquilo que não foi falado" (hooks, 2019, p. 36), a vida insalubre das pessoas na favela e o descaso das políticas públicas com esses sujeitos-favelados, para citarmos um exemplo. A literatura de Carolina provoca e engaja imagens dolorosas de ser, ver e ler, a saber, a pobreza, a fome, a miséria, o racismo, o machismo, entre outros.

A obra Quarto de Despejo: diário de uma favelada (2014), teve treze traduções ainda na década de 1960, ano em que foi publicada; no entanto, nem sempre foi considerada uma obra literária, muito menos um clássico, como não é até hoje.

Agora, na entrada do século XXI, a obra foi selecionada por bancas de vestibulares renomados do país - UNICAMP E UFRGS - e volta a incomodar, visto que se trata de uma obra em que a gramática normativa não é garantida, deste modo, é como se fosse um livro menor, já que a língua dos "gramáticos é um produto elaborado que tem a função de ser uma norma imposta sobre a diversidade" (GNERRE, 2009, p. 15), entre outras questões.

Há um discurso muito presente na escola sobre os clássicos em relação à linguagem das obras, a saber, que a leitura é "muito difícil" de compreender por conta do vocabulário rebuscado dos autores, isso sustenta a visão de que a literatura tem que garantir a "língua do poder político e cultural" (GNERRE, p. 16), por isso, uma obra clássica tende a fazer o "bom uso" linguístico da língua dita "culta", efeito que não se sustenta no caso de Carolina Maria de Jesus.

É só pensarmos nas obras de José Saramago, escritor renomado português que, em muitas 
de suas obras, não utiliza pontuação com parágrafos longos; no entanto, por valer o nome do autor, nesse caso, esse autor tem a autorização do dizer e sua obra se constitui como discurso legítimo.

Os vestibulares da UNICAMP e UFRGS ao selecionarem a obra de Carolina Maria de Jesus provocam a escola a ter que trabalhar com a literatura de autoria de mulheres negras e, como a maioria das instituições educacionais trabalham com a fôrma-leitor (PACÍFICO, 2002), isso causa não só estranhamento, mas também um árduo trabalho de elaboração de um conteúdo sobre a autora e sua obra para que elas cheguem aos livros didáticos.

A obra de Carolina presente na lista de um dos maiores vetibulares do país faz com que a escola comece a perceber a ausência de autoras negras em seus currículos e até mesmo provoca a universidade a refletir sobre a ausência desses sujeitos em suas ementas acadêmicas, provocando uma desestabilização dos juízos de valor, abrindo possibilidades para o discurso polêmico, isto é, o da disputa de sentidos, por sua vez, da polissemia.

Compagnon (2010) assevera que a teoria literária mesmo denunciando a questão dos juízos de valor, ainda assim, não conseguiu alterar o cânone, produzindo um efeito contrário ao consolidar os clássicos propondo a releitura dos mesmos textos, mas, por outras razões, razões novas e consideradas melhores que, sem dúvidas, não dão conta, segundo o autor, de explicar uma "racionalidade das hierarquias estéticas"; entretanto, isso não impede o "estudo do movimento de valores", como a história do gosto ou a estética da recepção, no final:

(...) Toda obra clássica contém, na verdade, uma fissura, o mais das vezes imperceptível aos seus contemporâneos, mas que não deixa de estar na origem de sua sobrevivência. Não se nasce clássico, torna-se clássico (...). (COMPAGNON, 2010, p. 242).

É nesse ponto que compreendemos que nossa dissertação pode contribuir para que as obras clássicas canonizadas deixem de ocupar esse lugar "mumificador" e passem a ser acessíveis a qualquer público, com seus "espaços vazados" (BRAGATTO FILHO, 1995) e suas "fissuras", que também autoras como Carolina Maria de Jesus deixem de ser discursivizadas como literatura menor, por meio de argumentos sustentados no discurso racista, afinal, a formação imaginária sobre o que é uma obra clássica, “imortal”, estará sempre ligada à questão do que se entende por língua, linguagem, literatura por meio de um funcionamento discursivo ininterrupto que é da ordem da língua e do político. Deste modo, 
Carolina Maria de Jesus é um clássico porque é melhor ler, do que não ler suas obras.

\begin{abstract}
O poder das palavras é enorme, especialmente o poder de algumas palavras, talvez poucas centenas, que encerram em cada cultura, mais notadamente nas sociedades complexas como as nossas, o conjunto de crenças e valores aceitos e codificados pelas classes dominantes (...) Isto aconteceu com muitas palavras-chaves da cultura ocidental do século XX como democracia, ditadura, etc. Na variedade padrão, então, são introduzidos conteúdos ideológicos, relativamente simples de manipular, já que as formas às quais estão associadas ficam imobilizados favorecendo, assim, quase que uma comunicação entre grupos de iniciados que sabem qual é o referente conceitual de determinadas palavras, e assegurando que as grandes massas, apesar de familiarizadas com as formas da palavras, fiquem, na realidade, privadas do conteúdo associado. (GNERRE, 2009, p. 20).
\end{abstract}

Se a linguagem é uma questão de poder, a autoria também o é, pois, ser autor é ocupar um lugar de/para poucos. Trabalhos como de Pacífico (2002) mostram que a argumentação e autoria na escola fracassam porque não há um compromisso dessa instituição com a transformação social e esse descompromisso contribui para que os sujeitos-alunos fiquem privados do seu direito à autoria, à argumentação e, no caso dessa pesquisa, à literatura.

Em uma sociedade silenciada pela censura, certamente, uma autora como Carolina Maria de Jesus será recusada, impedida, interditada, tendo suas obras utilizadas unicamente como "lenha da fogueira", afinal, não há espaço para o polissêmico em uma ditadura, muito menos, para o discurso polêmico em uma escrita que trata da "fome da escrita" e da "escrita da fome" (trataremos disso nos próximos capítulos), pois a única palavra de poder em um regime ditatorial é a da "ordem que não leva nunca ao progresso", mas sim, à aniquilação de tudo aquilo que vai contra o sistema de ordem vigente.

Para Orlandi (1997), na perspectiva discursiva, o silêncio é fundante na linguagem e não é transparente, se produz em condições específicas que constituem os seus modos de significar, o silêncio não fala, significa, não pode ser traduzido em palavras, deste modo, para ser compreendido o sentido do silêncio é preciso passar por métodos de observação discursivos.

As palavras são carregadas de silêncio, visto que ao dizer algo, outros sentidos ficam silenciados, deste modo, o silêncio não é a ausência de palavras, mas aquilo que em condições dadas não se diz, ou não foi permitido dizer, a fim de não causar uma ruptura significativa na relação dos sentidos. Por isso, Orlandi (1997, p. 102) vai chamar a atenção para não confundir silêncio com implícito, em que o primeiro tem relação com aquilo que é apagado, excluído, marginalizado; já o implícito é o não-dito que se define no dizer. 
Além do silêncio fundador, há a política do silêncio, que “(...) dispõe as cisões entre o dizer e o não-dizer (...)” (idem, 1997, p. 102) e está subdividida em: silêncio constitutivo (todo dizer silencia algum sentido) e silêncio local (a censura).

O silêncio constitutivo indica que todo dizer apaga outros, a partir de uma situação discursiva dada, em que para dizer é preciso não-dizer. Já o silêncio local é o da censura, isto é, a da interdição da inscrição do sujeito em formações discursivas determinadas, em que se é impedido de dizer, ou seja, o sujeito identifica-se com certas regiões do dizer, mas outras são proibidas (politicamente, moralmente, esteticamente) (ibidem, 1997, p. 103).

A censura, como diz Orlandi (1997, p. 107), impede o trabalho histórico do sentido e essa questão a respeito do silêncio local nos faz refletir sobre o espaço escolar que é, muitas vezes, permeado pela censura, assim como as feiras literárias e academias de Letras.

De um lado, temos as políticas públicas de educação com suas diretrizes que recaem no currículo da escola, em que certos saberes são selecionados e outros descartados, visto que a discussão sobre o currículo perpassa a questão da disputa e do poder. Diríamos que o livro didático é um exemplo da dimensão do currículo empregado pela escola que não permite a ruptura, a polissemia. Do outro lado, temos a escola e os sujeitos que a constituem que devem seguir as ordens que vem dessas políticas, representação da escola burocrática e hierarquizada.

Isso também nos leva a dizer que nem toda política pública é autoritária, contudo, nosso contexto sócio-histórico nos permite conceber que a escola ainda é esse lugar em que a burocracia está acima do pedagógico. Uma burocracia que funciona fazendo com que a escola gaste suas horas em tarefas que não contribuem para a aprendizagem. Uma discussão que merece ser aprofundada em outro texto, já que queremos chamar a atenção para o fato de que a formação de uma escola democrática, em que não existam hierarquias rígidas e autoritárias, só pode será alcançada se for construída.

Toda essa discussão sobre o funcionamento da escola contribui para observarmos que a literatura de autoria de mulheres negras ainda tem sido silenciada na escola (e outras instituições) por causa de um discurso sustentado em uma formação imaginária que diz não encontrar esse tipo de produção no mercado, reverberando o funcionamento do discurso autoritário em negação ao discurso polêmico (ORLANDI, 2012) por meio de uma ditadura do saber, em que certos saberes sofrem uma política de silenciamento, por exemplo, quando pensamos o modo como o sujeito negro é discursivizado dentro da escola, muitas vezes, na 
posição de objeto e não de sujeito.

Contudo, temos a resistência nesse movimento dos sentidos que são impostos e dos sentidos que são recusados (ORLANDI, 1997, p. 109), assim como dos saberes que podem e dos que não podem, por meio da relação de forças da posição de certos sujeitos que questionam os sentidos legitimados e impostos. O que faz com que o discurso, pelo viés da resistência, não seja a reversão do sentido que se está disputando, pois quanto mais negada é a multiplicidade dos sentidos, mais ela aparece, ou seja:

\footnotetext{
Podemos explicitar isso afirmando que, nesse caso, não se está dizendo o senso comum, mas referimos a ele para dizer outra coisa. Há, por assim dizer, um uso da vocação totalizante do sujeito à unicidade do sentido para, paradoxalmente, se dizer a "outra” coisa: é um mas não é "esse” um. (ORLANDI, 1997, p. 113).
}

Isso nos mostra que quanto mais há o desconhecimento e/ou negação das obras de Carolina Maria de Jesus e de outras mulheres negras, mais há mulheres negras resistindo, produzindo literatura, ocupando espaços sociais, levando a sua literatura a locais que as desconheciam e/ou negavam-nas, nesse jogo do não dizer pela resistência do dizer.

Há na sociedade uma tentativa de deslegitimar a política de reparação em relação às negras e negros do país, por meio de discursos que não levam em conta a questão histórica, social e ideológica para se discutir a condição do negro no Brasil, em especial o debate sobre o racismo, sustentado por dizeres como, por exemplo, as cotas raciais ferem o princípio de igualdade garantido no artigo $5^{\circ}$ da Constituição que diz que "todos" são iguais perante a leis sem distinção de qualquer "natureza"; ou que esse tipo de política subverte o princípio do mérito acadêmico; que as cotas abaixam a qualidade do ensino; favorece os negros e desfavorece os brancos, num suposto "racismo reverso"; que não dão conta do problema racial, visto que o acesso sem a garantia de permanência não resolve; o fato de termos uma sociedade miscigenada isso impossibilitaria a distinção de negros e brancos, entre outros discursos.

Há um modo de ler e interpretar a questão da condição do negro no Brasil que faz com que certos documentos pertinentes sobre esse assunto sejam mais "visíveis" e discursivizados, do que outros. E a literatura de mulheres negras, como um modo de funcionamento discursivo pela literatura permite a disputa dos sentidos, principalmente, em relação ao discurso dos clássicos, um "lugar" do dizer a partir da própria autoria da mulher negra e não do outro. A mulher negra na literatura torna-se sujeito deixando de ser objeto, por meio de uma produção 
quase sempre de:

\begin{abstract}
(...) autorepresentação, com uma dimensão política e social importante - a enunciação de realidades invisibilizadas, feita por setores sociais que historicamente têm tido um acesso mínimo à palavra escrita, em um contexto no qual a língua, sobretudo escrita, tem servido como mecanismo de dominação desde tempos coloniais. São obras que se colocam intencionalmente fora do cânone literário: pela temática, pelo "lugar" de onde se fala, pela utilização de uma linguagem híbrida carregada da oralidade popular, pelos meios de produção e distribuição que muitas vezes consistem em publicações artesanais e/ou independentes e venda de mão em mão nas ruas, bares e saraus, assim como a veiculação por meio de blogs e páginas de internet. Cada vez mais essas publicações vêm ultrapassando o âmbito das publicações independentes conquistando espaços no mercado editorial, e suscitando um crescente interesse na mídia e na academia. (REYES, 2013, p. 15).
\end{abstract}

Fernandez (2015) e Arruda (2015) argumentam que a linguagem híbrida presente nas obras de Carolina Maria de Jesus demonstra a versatilidade discursiva dessa autora que, apesar de ser aviltada por diversos críticos literários e até mesmo pela academia, sustentados na visão de que se trata apenas de uma mulher que escrevia diários, na verdade, essa autora sempre teve um compromisso com o seu projeto literário, produzindo uma literatura que passeia por diversos gêneros para além dos diários, o problema foi a falta de apoio do mercado editorial na publicização de suas obras (discussão que ainda aprofundaremos).

Como podemos observar, a literatura de autoria de mulheres negras oferece novos desafios à literatura brasileira pelo seu lugar de enunciação (não-lugar), pela linguagem empregada (híbrida), seu conteúdo e forma, provocando, do ponto de vista político, “(...) questionamentos sobre o potencial emancipador de movimentos de "baixo", perante a crise global dos Estados-nação, do liberalismo e da democracia representativa” (REYES, 2013, p. $15)$.

A literatura de autoria de mulheres negras traz rupturas e deslizamentos de sentidos em relação ao "universo compartimentado" que a escola trabalha, pois essas outras geografias do fazer literário fazem com que o "silenciado irrompa em gestos de resistência" (ORLANDI, 2017, p. 107), pois como sabemos que a ideologia é um ritual com falhas e, nesse sentido, o Estado também falha nos modos de inviduação do sujeito, produzindo a falta. E a falta é o lugar do possível, do "possível de que não seja assim, possibilidade do sentido outro, com a condição que ele ecoe na história, produzindo deslocamento" (idem, 2017, p. 107).

No caso de Carolina Maria de Jesus, analisamos como a escritora favelada, negra ocupa a posição sujeito-autor, e se significa nesse lugar social em sua posição-sujeito escritora de literatura. É pela escrita que seu gesto de resistência ecoa na história provocando e produzindo 
outros sentidos, outra posição-sujeito, outra prática social, por meio do furo da ideologia, visto que não é mais o sujeito-favelado apenas, e sim o sujeito-favelado autor e está aí o inusitado.

Por isso, marcamos a produção literária de mulheres negras, como a de Carolina Maria de Jesus, a partir do conceito de autoria, isto é, quando o sujeito se responsabiliza pelo seu dizer, dialoga com os sentidos sócio-históricos, rompe com a leitura parafrástica, literal e se autoriza a dizer (ORLANDI, 2012); (PACÍFICO, 2002) por meio de uma voz da resistência.

A literatura de autoria de mulheres negras é um modo de romper com o silêncio que, por meio da política literária, interdita o dizer, autorizando somente alguns sujeitos (principalmente os que já estão legitimados como clássicos) a serem autores de literatura, deste modo, se a concepção de obra clássica (sócio-histórico e ideologicamente construída) ajuda na legitimação de uma obra literária e seu autor, por outro lado exclui as autorias não hegemônicas.

Não nos interessa um cânone específico (visto aqui como uma instituição formada por sujeitos que administram, tomam decisões, escolhas, projeções e atingem lucros) para a literatura, muito menos a de autoria negra e outras marginalizadas, mas sim, pluralizar o conceito de cânone, por sua vez, o discurso de clássico, assim:

Se, por força de características peculiares, a literatura feita por negros ou por descendentes assumidos de negros concretizar linguagens geradoras de cânones de poética nova, essa dimensão se inserirá necessariamente no processo da literatura brasileira e não no nicho discriminatório de uma literatura "negra" ou "marrom". (PROENÇA FILHO, 2010, p. 67).

Apesar dos riscos, concordamos com a citação de Proença Filho que se trata de uma dimensão complexa e repleta de opacidade - a (nome)ação da literatura produzida por mulheres e homens negros e negras - em que, ao mesmo tempo que nomear literatura feminina negra, literatura negra-brasileira, literatura afrodescendente, entre outras, busca-se o não silenciamento em relação ao racismo ainda vigente no país, que interdita autoras e autores negros e negras e suas obras, ainda assim, corre-se o risco de essas categorias ou nomeações criarem um efeito de sentido de um "lugar" pré-determinado a esses sujeitos-autores, o que não avança.

Por isso, "em lugar de literatura negra se defenda a presença do negro ou da condição negra na literatura brasileira" (PROENÇA FILHO, 2010, p. 68), como uma tentativa de fugir do jogo preconceituoso e discriminatório afirmando e reconhecendo o direito à autoria e à 
literatura de autoria de mulheres negras. Nesse sentido, o "opositor não é o sujeito branco, mas o branco preconceituoso" (idem, 2010, p. 66), acrescentaríamos também o sujeito-branco discriminador, portanto, nomear literatura afro-brasileira tende a ser o melhor caminho, entretanto, continuaremos a nomear literatura de autoria de mulheres negras, na tentativa de defendermos a posição sujeito-autor de literatura.

Diante de toda a discussão feita até aqui sobre a impossibilidade de uma definição concreta e unívoca a respeito do que faz uma obra de literatura ser considerada um "clássico", "imortal”, autorizada a fazer parte do cânone, a não ser pela via da disputa política representação da política literária - concluimos que nem o conceito sobre o que é literatura e nem o discurso sobre as obras clássicas conseguem impedir a resistência da autoria das “margens", que reivindicam outras geografias de produção literária e seu direito à escrita.

Deste modo, observaremos o terceiro funcionamento da política literária: o discurso do mercado editorial, como voz que legitima, ou não, a autoria de certos sujeitos-autores, procurando analisar o modo como a escrita de Carolina Maria de Jesus, nos anos 60, do século XX, foi recepcionada e, por fim, como a voz dessa escritora pode ser pensada, refletida, argumentada na contemporaneidade, isto é, quais efeitos de sentido a literatura de Carolina Maria de Jesus provoca na sociedade atual.

\subsection{A questão do mercado editorial como voz que legitima, ou não, a autoria}

“Vivifico-me eu-mulher e teimo,/ na vital carícia de meu cio,/ na cálida coragem de
meu corpo,/ no infindo laço da vida,/ que jaz em mim/ e renasce flor fecunda./
Vivifico-me eu-mulher./ Fêmea. Fênix. Eu fecundo". (Conceição Evaristo)

Nas discussões anteriores, procuramos mostrar a importância da concepção de literatura e de obra clássica que a escola (e outras instituições) adota, pois, dependendo de qual for, implicará a escolha das autoras e autores e suas obras no currículo da escola. Essas escolhas funcionam devido à política literária em que a literatura deixa de ser um campo apenas da palavra, do livro, do autor, para um campo político poderoso.

Nesse sentido, temos procurado argumentar que a literatura produzida por Carolina Maria de Jesus é um ato político afrontoso, ainda mais, por tratar-se de uma mulher negra favelada, isto é, Carolina ao ocupar a posição discursiva de autor faz ranger o silenciamento da autoria de mulheres negras, produzindo o exótico, isto é, o novo, o polissêmico.

A política literária, ao legitimar e/ou interditar certas autoras e autores e suas obras, 
conforme temos discutido, atrela-se ao conceito de língua e linguagem que, por sua vez, recai no conceito de literatura e do que seja uma obra clássica pertencente a um determinado cânone, porém, há um terceiro fator em que essa política também atua: o mercado editorial.

Não convém, neste trabalho, fazer uma reflexão e análise de modo aprofundado sobre a questão do mercado editorial, mas sim, pela Análise de Discurso, buscar compreender o(s) funcionamento(s) discursivo(s) do mercado editorial, pois acreditamos que essa questão, junto à concepção de literatura e de obra clássica, ajuda-nos a compreender o modo como a política literária atua autorizando certas autoras e autores e suas obras de circularem socialmente, no nosso caso, em especial na escola, tendo o trabalho do simbólico e do discurso na base da produção da existência do humano.

O mercado editorial faz uso da voz publicitária para veicular os seus produtos. E a publicidade é algo constitutivo da sociedade contemporânea capitalista que tende a determinar o acesso à literatura aos sujeitos-consumidores, portanto:

(...) A publicidade exerce influência decisiva sobre os gostos, a sensibilidade, a imaginação e os costumes. A função antes desempenhada, nesse âmbito, por sistemas filosóficos, crenças religiosas, ideologias e doutrinas (...) hoje é exergcida pelos anônimos "diretores de criação" das agências publicitárias (...). (LLOSA, 2013, p. 33).

Concordamos com Llosa (2013) quando diz que na contemporaneidade uma obra de literatura passou a ser considerada um produto comercial, cuja veiculação e legitimação versus negação e interdição estão presentes nesse jogo dos vaivéns do mercado, em que o "preço passou a se confundir com o valor de uma obra de arte" (idem, 2013, p. 33), portanto, o mercado editorial materializado no discurso da publicidade é uma voz de autoridade em relação à literatura, pelo seu poder de convencimento e propagação.

Retomando os conceitos teóricos da $\mathrm{AD}$, temos que o sujeito ocupa uma posição no discurso para interpretar e, em consequência disso, produz sentidos, no entanto, por estar na evidência dos sentidos o sujeito não questiona esse "parecer evidente", como se fosse apenas possível dizer daquela forma e não de outra, desconsiderando a construção e historicidade dos sentidos, visto que:

(...) o sujeito se constitui por interpelação - que se dá ideologicamente pela sua inscrição em uma formação discursiva - que, em uma sociedade como a nossa, o produz sob a forma de sujeito de direito (jurídico). Esta forma-sujeito corresponde, historicamente, ao sujeito do capitalismo, ao mesmo tempo determinado por condições externas e autônomo (responsável pelo que diz), um sujeito com seus 
direitos e deveres. (ORLANDI, 2013, p. 45).

A forma-sujeito vincula-se ao processo de assujeitamento que afeta os indivíduos a serem interpelados em sujeito (PÊCHEUX, 2009), deste modo, na contemporaneidade o sujeito é ao mesmo tempo livre e submisso em relação à estrutura jurídica, diferente da Idade Média, em que a forma-sujeito da Religião ditava a subordinação às regras dos espaços sagrados do cristianismo legitimando a divisão social entre súditos, senhores e nobreza (HAROCHE, 1992).

Na Modernidade, a partir do século XVI, a subordinação passa a ser ao jurídico, isto é, à forma-sujeito jurídico (HAROCHE, 1992) em que essa mudança altera o poder passando da Religião para o Estado. Sendo assim, a obediência deixa de estar ligada às leis divinas e passa a ser ditadas pelas leis jurídicas (PAYER, 2005).

Temos, então, transformações na estrutura do poder que interferem na constituição da forma-sujeito. Isso faz com que se considere a interferência da exterioridade na produção dos enunciados, já que tais alterações são influenciadas pelo poder das instituições em que se observa, em especial, o valor que a sociedade atribui ao mercado na atualidade.

O mercado ganha status e destaque nas decisões do Estado na forma como estabelece a sua organização e nas relações entre os sujeitos. É só pensarmos na globalização e nos seus efeitos na relação entre os Estados e as fronteiras estabelecidas, provocando novas configurações geopolíticas, por exemplo, a União Europeia, assim:

(...) Tudo indica que um novo Texto vem adquirindo o valor de Texto fundamental na sociedade contemporânea: um texto cujo poder de interpelação sobre os indivíduos vem se equiparando àquele que o Texto sagrado ocupa na ordem religiosa, na Idade Média, e que o Texto da lei jurídica ocupa na ordem do Estado Moderno. Este grande texto da atualidade, no meu modo de entender, consiste na Mídia, daquilo que está na mídia, em sentido amplo, e em especial no marketing, na publicidade. O Valor que a sociedade vem atribuindo à mídia - ou o poder de interpelação que a Mídia vem exercendo na sociedade - passa a assegurar-lhe o papel de Texto fundamental de um novo grande Sujeito, o Mercado, agora em sua nova forma globalizada. (PAYER, 2005, p. 16).

Em relação ao mercado editorial, novos modos de consumir o livro são produzidos, seja por meio das livrarias físicas; seja por meio das livrarias virtuais, que trabalham, a partir do discurso do marketing, modos de capturar o sujeito para a compra de seus produtos.

No entanto, quando a discussão é a produção literária de autoria de mulheres negras, 
percebe-se que tanto as livrarias físicas, quanto as virtuais, ainda não garantem o acesso a essas escritoras que, a nosso ver, é um modo de interdição do funcionamento da política literária, por conta disso, temos uma produção e a propagação cada vez mais crescente de editoras independentes. Por editora independente entende-se modos de produção do livro que foge das grandes e renomadas editoras do país.

Essa interdição às obras de autoria de mulheres negras nas livrarias produz efeitos de sentidos como: 1. Não existem mulheres negras autoras de literatura; 2. As obras literárias dessas mulheres não vendem; 3. Não tem qualidade a produção dessas mulheres negras. Como podemos notar, o efeito de negação é o tempo todo materializado no discurso, silenciando a produção de autoria negra por meio de um processo de negação e/ou desconhecimento, funcionamento que se dá por conta de todo um processo histórico-socialideológico em que não cabia/cabe o direito à fala, muito menos, à escrita, raízes da estrutura social racista ainda presente na contemporaneidade.

Ao investigarmos, por exemplo, a Flip - Festa Literária Internacional de Paraty - um dos maiores eventos literários do país, é possível verificar que somente no ano de 2017 um autor negro foi homenageado, Lima Barreto, com uma programação repleta de autores negros, brasileiros e estrangeiros.

Essa escolha, a nosso ver, não se deu de modo neutro, segundo o discurso de que o "sol é para todos"; antes, constitui-se em uma escolha política a partir de condições de produção em que o discurso a respeito da autoria negra passou a constituir uma formação discursiva respeitada, pois como já mostramos na discussão sobre os clássicos, há um "modismo" que regula a legitimação de certas literaturas. Entretanto, o evento da Flip 2017 não se reduz a isso, visto que há todo um processo de resistência do protagonismo do negro que lutou e continua a lutar pelo seu direito à existência, isto é, a garantia do seu espaço na sociedade.

Se as livrarias mais populares não proporcionam a viabilização das obras de autoras negras e negros tanto quanto o faz com outros, com as novas formas de empreendimento na atualidade, muitas editoras passaram a veicular a venda de obras de literatura de autoria negra, por exemplo, de modo independente, é o caso da editora Malê, Mjiba, Mazza Edições, Pallas Editora, entre outras, em que é possível ter acesso a obras literárias de autoria negra, inclusive, muitas dessas editoras foram fundadas e administradas por mulheres negras, como a Mjiba, por exemplo.

Além disso, há muitas autoras e autores que publicam suas obras em seus sites, blogs, 
redes sociais, nos quais o leitor pode ter acesso direito a elas e a eles pelo virtual, muitos ainda carregam seus livros nas feiras literárias, saraus, seminários, rodas de conversa literárias, nas ruas, praças, universidades, entre outros lugares, assim, criam modos de acesso a suas obras, por exemplo, a editora Invisíveis Produções que, em 2017, produziu a antologia Trans, organizada pelo Cursinho Popular Transformação, voltada para pessoas transgêneros, travestis e não binárias, em São Paulo, em que são mais de 30 poetas transexuais, travestis e não binários que materializam a sua produção poética nessa obra, muitos desses sujeitos comercializam essa obra quando recebem convites de participações em eventos literários específicos.

$\mathrm{Na}$ heterogeneidade dos modos de comercialização das obras literárias, muitas autoras negras reivindicam o seu direito em ter suas obras nas livrarias populares; outras, preferem o caminho da produção independente, como um modo de combater o capitalismo hegemônico, isto é, aquele que comercializa apenas o que mais vende no mercado. Como podemos notar, as literaturas sempre buscaram brechas, modos de furar a interdição a fim de circularem socialmente, seja pela literatura oral, seja pela escrita.

No entanto, a circulação de uma literatura não é garantia que ela seja reconhecida no tocante à respeitabilidade literária e classificada como uma obra clássica pertencente a um determinado cânone, a nosso ver, a lógica vigente do mercado funciona na lógica do consumo, isto é, o vender está acima de qualquer suposta "qualidade" literária; portanto, o mercado editorial, pelo discurso da propaganda, formula modos de enunciar seus produtos, consequentemente, criam modos de fazer funcionar o discurso da "qualidade" a respeito das obras que comercializa, produzindo esse discurso.

Isso pode ser constatado no modo como as livrarias de shoppings organizam o seu acervo que, geralmente, tende a valer mais o nome do autor do que a obra em si. É o caso dos livros de artistas, youtubers, autoajuda, entre outros, em que a garantia da venda está ligada ao nome do autor.

Para discutirmos a questão do nome do autor é preciso nos remetermos a Foucault que, em 22 de fevereiro de 1969, proferiu uma conferência importante, intitulada $O$ que é autor (2001), em um encontro da Sociedade Francesa de Filosofia. É importante ressaltar que Foucault trabalha a noção de autor restrita ao grupo de escritores legitimados, já Orlandi (2012) trata da noção de autor a partir de uma perspectiva discursiva, em que dizer já implica a possibilidade de ser autor, isso porque nem sempre o sujeito consegue colocar-se na posição 
de autor de seu dizer, por questões também discursivas que ainda abordaremos.

Foucault começa sua conferência com a pergunta “que importa quem fala?", trazendo a questão do apagamento do autor e argumenta que constatar o seu desaparecimento não é o essencial, mas sim, descobrir os locais onde a função autor é exercida. Para a Análise de Discurso, essa função leva em conta a dispersão do sujeito em várias posições diferentes, de acordo com as relações que se estabelecem nas formações discursivas, deste modo, não importa o sujeito empírico, mas "o processo de dispersão deste que constroi a ilusão de unidade passível de referencialidade" (PFEIFFER, 1995, p. 46).

A escrita é o lugar onde o sujeito é apagado, não importa quem fala, mas o que se fala, em que o "sujeito tem que se presentificar como $\underline{\mathrm{UNO}}$, discreto, determinado, (grifos do autor) pois que se submete à determinação da língua" (PFEIFFER, 1995, p. 46).

O autor está ligado ao lugar que se pode ocupar no discurso e que exerce determinadas funções. Isso não significa negar a existência do "indivíduo que escreve", como apontou Foucault, mas implica compreender que esse "indivíduo" não tem um lugar imediato e natural no discurso.

Para refletir sobre a questão do "desaparecimento" do autor, ou seja, sua dispersão, Foucault (2001) questiona a noção de obra e escrita. Em relação à primeira, o autor vai dizer que a palavra "obra" e a unidade que ela designa são tão problemáticas quanto a individualidade do autor, pois não há uma teoria sobre obra e, muito menos, deve-se analisar/avaliar uma obra em sua relação com o seu autor, mas, antes, analisa-se na “(...) sua estrutura, na sua arquitetura, na sua forma intrínseca e no jogo de suas relações internas (...)” (idem, 2001, p. 271). Já em relação à segunda, a noção de escrita para esse filósofo “(...) igualmente obscurece a idéia de desaparecimento do autor como unidade e ser empírico no mundo, já que a escrita tem que se apresentar como unidade, coerência e coesão" (PFEIFFER, 1995, p. 47).

A partir desses pontos, Foucault argumenta que é preciso localizar o espaço deixado vago pelo desaparecimento do autor, observar as lacunas, as falhas, então, começa a tratar dos problemas suscitados pelo uso do nome de autor, o que é o nome do autor? E como ele funciona?

Foucault vai dizer que o nome de autor é, primeiramente, um nome próprio, ou seja, um significante que designa um indivíduo histórico específico e discreto, todavia, um nome de “autor" vai muito além de um nome próprio. Por exemplo, quando dizemos Pechêux, ou o 
próprio Foucault, dizemos algo que vai além dos seus nomes, de suas existências, pois também dizemos sobre os seus escritos, ou forma de discurso, a teoria, as citações que estão associadas a esses nomes, sendo assim o nome próprio de um autor oscila entre dois pólos: a designação à pessoa (empírica) e a que se refere aos conceitos, ideias, à obra associados com o nome.

Postas as considerações anteriores, Foucault escreve que o nome do autor não é propriamente como o nome próprio, visto que o nome de autor pode (re)agrupar vários indivíduos ou mesmo "vários autores" (caso de Fernando Pessoa e seus heterônimos), pois a relação entre o nome próprio com o indivíduo nomeado e a ligação do nome de autor com aquilo que nomeia não são isomórficos e não funcionam da mesma forma, visto que estão situados nos dois polos da descrição e da nomeação.

Ele também vai dizer que um nome de autor não é simplesmente um elemento de um discurso, mas que também assegura uma função classificatória. O nome de autor serve para caracterizar um certo modo de ser do discurso que deve ser recebido de certa maneira e que, numa determinada cultura, recebe um certo estatuto, por fim, constata que o nome de autor não está cravado no estado civil dos homens, muito menos na ficção da obra, mas, sobretudo, na ruptura que instaura um certo grupo de discursos e o seu modo de ser singular.

Como podemos notar, Foucault não procura "fechar os sentidos" da discussão sobre autor, mostrando que o autor não está nem no estado civil dos homens, nem na ficção da obra, em que duvida da noção de "obra" e distingue categorias de autor: o autor propriamente dito, o fundador de discursividades, fundador de cientificidade; no entanto, antes de tratarmos disso, convém apresentarmos as quatro características do funcionamento da função autor nos discursos em uma dada cultura e sociedade.

A primeira é a apropriação. O texto é considerado uma propriedade do autor e isso inicia no momento em que a figura do autor se tornou passível de punição e os discursos podiam ser transgressivos. Porque há a detecção da transgressão que é possível punir-se o autor; deste modo, temos a instauração da propriedade privada do texto suscetível de ser criticada, portanto, os direitos do autor são legalizados institucionalmente.

A segunda é a fiabilidade, em que o nome de autor produz um efeito de verdade e valoração do texto, sobre isso, Pfeiffer (1995, p. 18) faz um adendo dizendo que é importante lembrarmos que o efeito de verdade pressupõe a incredulidade e o de valoração pressupõe a desconsideração. Sabe-se que nem sempre foi necessário que um texto carregasse a autoria 
para ser legitimado, contudo, desde a Idade Média, uma certa tese era aceita quando se citava um autor consagrado. Em contrapartida, a partir dos séculos XII/XIII, o fato de um texto configurar-se como acadêmico-científico faz com que seja reconhecido como detentor de verdades inquestionáveis, provadas pela voz da ciência - voz universal - maior do que a do nome individualizado do autor. O que não acontece quando se trata da literatura, pois, para Foucault, é imprescindível aos textos literários virem dotados de uma autoria individualizada que lhes atribui valor.

Em relação ao fato de Foucault desconsiderar o nome de autor no discurso científico em seu funcionamento, Pfeiffer (1995, p. 49) vai dizer que o autor pode não estar produzindo o valor de verdade em si, mas provoca efeitos nos leitores e em outras instâncias (órgãos fmanciadores, editoras, universidades, distribuídoras etc.), sendo assim:

\begin{abstract}
O nome de autor, por exemplo, tem em si uma carga avaliativa: conforme o nome do autor, um órgão financiador de pesquisa "opta" pela liberação da verba ou não. $\mathrm{O}$ mesmo ocorre com as editoras ao optarem por um ou outro livro. Quais são os livros que são expostos nas vitrines das livrarias?! A vitrine é um chamariz, um meio de marketing, não podemos nos esquecer disto. Pensar sobre a circulação de um discurso não é restringir-se ao momento da leitura, mas levar em consideração desde a sua produção (do texto) até os meios pelos quais ele chega às mãos do leitor (editoras, universidades, livrarias, congressos, circulação interna à universidade, etc). (PFEIFFER, 1995, p. 49).
\end{abstract}

Essa questão é bastante pertinente para este trabalho porque quando tratamos da literatura produzida por mulheres negras, muitas delas além de estarem silenciadas, no sentido emprestado de Orlandi (1997), o da censura, as que conseguem alcançar mais visibilidade também não são reconhecidas por algumas instituições como autoras consagradas. É o nome de autor com toda a sua carga avaliativa e valorosa deixado à margem.

No caso de Carolina Maria de Jesus, na década de 60, do século XX, é o nome de autor que confere uma certa legitimidade (frágil) para a sua primeira obra publicada, em que o furor e estranhamento em relação à autoria do didário e à alta vendagem da obra, Quarto de Despejo: diário de uma favelada (2014), estão diretamentes ligados ao nome de autor, pois podemos dizer que a partir do seu "lugar" de enunciação essa autora "inaugurou", digamos assim, um modo de fazer valer a autoria dos subalternos, em especial, os favelados.

Voltando às quatro características da função autor de Foucault, a terceira, está na base da concretute e unidade a um ser que chamamos de autor, mesmo não existindo como tal. A função autor é uma construção resultante de uma operação complexa que constroi um certo 
ser "racional". É uma construção histórica e a crítica literária moderna, segundo Foucault, apoiou-se nos princípios da exegese cristã. São Jerônimo definiu os critérios básicos da autoria: constância; coerência teórica; unidade estilística e contexto. Como podemos observar, o autor tem a função de dar concretude e unidade ao texto, portanto, é o responsável pela sua obra.

Por fim, a quarta e última característica aponta que nos discursos com função autor são ouvidas diversas vozes na "confluência, na tensão do sujeito disperso que o sujeito-autor funciona, movimenta-se, produzindo o efeito de unidade" (PFEIFFER, 1995, p. 50).

A partir dessas considerações, Foucault distingue os autores "fundadores de discursividades" dos, simplesmente, "autores". Os primeiros estão na origem de uma proliferação de discursos, possibilitando a outros autores a regra de formação de outros textos, pois, "instaurar novos discursos significa tornar possível que se instaurem oposições, contradições a estes discursos” (PFEFFEIR, 1995, p. 51), nessa direção, Marx, Saussure e Freud são instauradores discursivos, pois estão ligados à ruptura com o que se dizia sobre determinado campo do saber, eles instauram o novo. Diferindo da fundação de uma nova cientificidade que pressupõe a continuidade, por exemplo, temos Chomsky, que funda uma nova cientificadade a partir do fundador de discursividade Saussure.

Ao introduzir a noção de "retorno das origens" para se pensar o processo de instauração discursiva, Foucault em oposição a ela traz a noção de "redescoberta" e "reatualização". A "redescoberta" está ligada ao processo no qual uma noção (esquecida, esboçada) é retomada; porém, de outro modo em uma nova teoria. Já "reatualização" “(...) é a reinscrição de um discurso científico num outro domínio a título de generalização ou aplicação ou ainda de transformação" (PFEIFFER, 1995, p. 51). A característica constitutiva da instauração de uma discursividade necessita do esquecimentos:

(...) Para que a ruptura se dê, é preciso que seja construído um espaço vazio onde ilusoriamente se encaixa como novo e transparente/evidente um DIZER. Faz parte da dialética constitutiva da linguagem que na instauração do novo haja o esquecimento do DITO para que um outro DITO, com vestes de obviedade, fixe-se. Há de ficar claro que esquecimento e instauração são ambos constitutivos e se dão mutuamente no processo de ruptura discursiva. É por isso que o "outro dito" toma as vestes de original, de acabado (finalizado): daquele que vai ocupar o lugar vazio, ilusoriamente não preenchido. (PFEIFFER, 1995, p. 51).

É importante observar que a instauração discursiva não é um pressuposto para que o sujeito ocupe a função-autor, pois a autoria, segundo Pfeiffer (1995, p. 52) não está ligada à 
ideia de ruptura, pois é somente o exemplo maior e mais complexo de um processo de autoria.

Diante de tudo que foi exposto até aqui sobre a questão da autoria em Foucault, interessa-nos, sobretudo, o fato de que a função autor remete a várias posições-sujeito que classes diferentes de indivíduos podem vir ocupar. Deste modo, ocupar a posição de sujeitoautor não é uma tarefa fácil e está ligada ao poder, pois significa estar autorizado (ou autorizar-se pela resistência) a produzir sentidos. Em outra obra, esse mesmo autor escreve sobre o poder e o controle dos discursos:

\footnotetext{
Desta vez, não se trata de dominar os poderes que eles têm, nem de conjurar os acasos de sua aparição; trata-se de determinar as condições de seu funcionamento, de impor aos indivíduos que os proununciam certo número de regras e assim de não permitir que todo mundo tenha acesso a eles. Rarefação, desta vez, dos sujeitos que falam; ninguém entrará na ordem do discurso se não satisfizer a certas exigências ou se não for, de início, qualificado para fazê-lo. Mais precisamente: nem todas as regiões do discurso são igualmente abertas e penetráveis; algumas são altamente proibidas (...), enquanto outras parecem quase abertas a todos os ventos e postas, sem restrição prévia, à disposição de cada sujeito que fala (FOUCAULT, 2007, p. $37)$.
}

A "satisfação" das exigências do dizer, assim como estar "qualificado" para ocupar a posição discursiva de autor são pontos nodais em relação à literatura de autoria de mulheres negras, pois esses procedimentos limitadores internos recorrem a rituais que definem quem atende às condições para entrar na ordem discursiva.

Por isso, é importante o conceito de condição de produção que, pensada em um sentido estrito, refere-se ao contexto imediato da enunciação; por sua vez, pensadas em sentido amplo, incluem o contexto sócio-histórico e ideológico.

\subsection{Condições de produção que sustentam a construção de/em Carolina Maria de Jesus}

As condições de produção, em um sentido amplo, consideram o contexto sóciohistórico e também o imaginário produzido pelas instituições, sobre dado objeto discursivo. Elas estão ligadas aos aspectos históricos, sociais e ideológicos que envolvem o discurso, que possibilitam e determinam a produção do discurso, ou seja, para Pêcheux (2014) as "circunstâncias" de um discurso são suas condições de produção, portanto, o processo de produção do discurso é o conjunto de mecanismos formais que produzem um discurso de um tipo dado em condições de produção dadas, pois: 


\begin{abstract}
Um discurso é sempre pronunciado a partir de condições de produção dadas: por exemplo, o deputado pertence a um partido político que participa do governo ou a um partido da oposição; é porta-voz de tal ou tal grupo que representa tal ou tal interesse, ou então está ‘isolado’ etc. Ele está, pois, bem ou mal, situado no interior da relação de forças existentes entre os elementos antagonistas de um campo político dado. O que diz, o que anuncia, promete ou denuncia, não tem o mesmo estatuto conforme o lugar que ele ocupa; a mesma declaração pode ser uma arma temível ou uma comédia ridícula segundo a posição do orador e do que ele representa, em relação ao que diz. Um discurso pode ser um ato político direto ou um gesto vazio, para 'dar o troco', o que é uma outra forma de ação política. (PECHÊUX, 2014, p. 76).
\end{abstract}

Feitas essas considerações sobre as condições de produção do discurso, vejamos como esse conceito funciona no caso de Carolina Maria de Jesus, ou seja, como a relação dos interlocutores, a exterioridade, as circusntâncias de produção dos discursos de e sobre Carolina Maria de Jesus, o processo sócio-histórico dos sentidos sobre negros, brancos, escravos, escravizados, pobres, favelados, escritores, autores, literatura, enfim, afetaram a construção do sujeito-autor Carolina Maria de Jesus e de sua obra.

Há, ainda hoje, a presença do discurso da existência de uma "democracia racial" no Brasil, difundido em certos círculos acadêmicos, nas escolas, nas políticas públicas e entre outros espaços sociais, que relativizam a opressão e a tragédia de mais de três séculos de escravidão no país, impedindo uma discussão mais aprofundada sobre essa questão: a do racismo, presente ainda na contemporaneidade por meio de outras estratégias de coerção. A literatura, arte que busca "desmascarar" e humanizar, poucas vezes ousou fazer um debate sobre esse assunto e, quando o fez, deparou-se com o desconhecimento e/ou a negação do desprezo da academia.

Um desses discursos muito frequentes na escola é quando o professor solicita aos estudantes uma produção textual acerca do tema sobre o funcionamento do racismo na sociedade brasileira e, por não terem tido acesso ao arquivo sobre esse assunto, as produções dos alunos acabam se pautando na paráfrase, em que muitos desses sujeitos-alunos terminam a produção textual com o seguinte enunciando: $O$ racismo tem que acabar, pois todos nós somos iguais.

E se somos iguais por que há uma população que ainda luta pela garantia dos seus direitos? Que "igualdade" é essa que a escola discursiviza em seu espaço e não estranha sentidos outros? Há o discurso do mito da democracia racial funcionando em que, mesmo com a constatação dos fatos que comprovam a existência violenta do racismo na sociedade 
brasileira, tenta amenizar o discurso sobre a população negra, colocando os sujeitos que sofreram todo tipo de violência, injustiça e desigualdade como parte dos "iguais", construindo, com isso, um modo de silenciamento dessa questão, em que:

\begin{abstract}
Os menos enganados pelos vários mitos tecidos em torno à escravidão no Brasil foram os africanos, que conheciam na própria pele as influências "mitigadoras" da Igreja Católica e as "benevolências" do português. Desde o início da escravidão, os africanos confrontaram a instituição, negando fatalmente a versão oficial de sua docilidade ao regime, assim como sua hipotética aptidão natural ao trabalho forçado. Eles recorreram a várias formas de protesto e recusa daquela condição que lhes fora imposta, entre as quais incluíam o suicídio, o crime, a fuga, a insurreição, a revolta. $\mathrm{O}$ afrodescendente escravizado praticou, ainda, a forma não violenta ou pacifista de manifestar sua inconformidade com o sistema. Foi o mais triste e trágico tipo de rejeição - o banzo. O africano era afetado por uma patética paralisação da vontade de viver, uma perda definitiva de toda e qualquer esperança. Faltavam-lhe as energias, e assim ele, silencioso no seu desespero crescente, ia morrendo aos poucos, se acabando lentamente. (NASCIMENTO, 2016, p. 70).
\end{abstract}

É a resistência da população negra que a fez chegar ao século XXI como sujeitosresistência. Temos aqui uma evocação do direito de existência, isto é, sujeitos que lutam para que não sejam invisibilizados, calados, massacrados, dizimados.

No ano de 2012, foi publicada a pesquisa, Práticas pedagógicas de trabalho com relações étnico-raciais na escola na perspectiva da Lei 10.639/03. Ela nasceu da parceria coordenada pela Doutora Nilma Lino Gomes (Ministra-Chefe do Ministério das Mulheres, Igualdade Racial e Direitos Humanos), financiado e apoiado pelo Ministério da Educação (MEC), por meio da Secretaria de Educação Continuada, Alfabetização e Diversidade (SECAD) e a Representação da UNESCO no Brasil.

O intuito era avaliar, mapear e coletar subsídios em forma de dados que possibilitassem a melhoria nas políticas educacionais para uma implantação efetiva da lei em questão. A duração da pesquisa foi de 9 meses, sendo analisadas escolas de todo o território brasileiro. Os princípios norteadores da pesquisa levaram em consideração os comandos intrínsecos no Parecer 003/2004, do Conselho Nacional de Educação, que são a "reparação, reconhecimento e ações afirmativas".

No estado de São Paulo, a escola selecionada era pertencente ao município de Campinas e apresentou um projeto chamado Africanidades. As atividades realizadas pelo projeto atingiam todas as disciplinas com apoio e orientação do professor de História e os resultados alcançados na escola são essenciais para o entendimento do impacto da implantação da lei 10.639 . 
Na pesquisa, foi possível realizar um comparativo entre o efeito alcançado em escolas que o corpo docente atua em conjunto no desenvolvimento de práticas transformadoras mediante a mudança trazida pela lei; e aqueles que agem com postura negligente e omissa, por meio de um funcionamento discursivo de desconhecimento e/ou negação, tanto da lei, quanto das questões que envolvem a lei e a promoção de práticas antirracistas.

Ao discorrermos sobre essa legislação que introduziu a obrigatoriedade da temática História e Cultura Afro-brasileira, Africana, no currículo oficial na Educação Básica e no Ensino Superior, adiantamos que é importante compreender que a implantação dessa lei envolve todo um processo social, histórico, político e ideológico até a sua sanção. Diríamos que há todo um jogo discursivo que ora avança, ora estagna, em relação ao reconhecimento e valorização da população negra; um jogo de disputas ideológicas em que, quanto mais se tenta silenciar; mais há, também, modos de resistência contra esse silenciamento (ORLANDI, 1997).

A educação nacional após a promulgação da lei 10639/03 "transpassou a muralha" que silenciava a existência do racismo institucional e a estrutura racista intrínseca na sociedade brasileira, desde o período escravocrata. Tem-se nesse momento a conquista de um direito social e democrático que engloba as questões sociais, históricas, políticas e ideológicas debatidas na atualidade, seja por meio dos movimentos sociais; seja por meio de outros espaços como o da academia, que (re)toma um debate sobre a população negra que foi (e é), muitas vezes, interditado e lido como assunto menor.

O ex-presidente Luiz Inácio Lula da Silva, em 10 de março de 2008, sancionou a lei 11.645 para que a obrigatoriedade de ensino alcançasse também a história indígena, um apagamento que a lei 10.639 deixou passar, isto é, um furo que o texto da lei não se atentou. Pode-se inserir nesse rol, a elaboração do Parecer do CNE 16/2012 e a Resolução n8/2012 que também instituíram as Diretrizes Curriculares para a Educação Escolar Quilombola na Educação Básica, nas escolas localizadas dentro de comunidades e escolas que atendam estudantes quilombolas, devido à necessidade de um ensino que alcance a complexidade e o resgate histórico da população quilombola brasileira.

Durante anos foram realizadas pesquisas e atividades impulsionadas pelo Movimento Negro, academia, juristas e profissionais da Educação em geral, que criaram dados sobre a importância do estudo das relações étnicos-raciais e a necessidade de mudança no ordenamento jurídico brasileiro. Ações que contribuem para a desconstrução do discurso 
embasado no mito da democracia racial e a formulação de políticas educacionais amparadas na diversidade cultural com foco em práticas antirracistas.

O significado político desse comando em paralelo à demanda da população afrodescendente atingiu, diretamente, "o princípio de direito à educação", trazida pela Constituição Federal, haja vista que esses conteúdos devem ser ministrados no âmbito de todo o currículo escolar.

No Parecer 003/2004 homologado pelo Conselho Nacional de Educação (CNE) sobre as Diretrizes Curriculares, por meio da Resolução $\mathrm{n}^{\circ} 1$, de Junho de 2004, tem-se um discurso que reconhece e valoriza o direito dos negros tendo como objetivo superar a desigualdade étnico-racial presente na educação escolar brasileira, ao dizer que:

\footnotetext{
Reconhecimento implica justiça e iguais direitos sociais, civis, culturais e econômicos, bem como valorização da diversidade daquilo que distingue os negros dos outros grupos que compõem a população brasileira. E isto requer mudança nos discursos, raciocínios, lógicas, gestos, posturas, modo de tratar as pessoas negras. Requer também que se conheça a sua história e cultura apresentadas, explicadas, buscando-se especificamente desconstruir o mito da democracia racial na sociedade brasileira; mito este que difunde a crença de que, se os negros não atingem os mesmos patamares que os não negros, é por falta de competência ou de interesse, desconsiderando as desigualdades seculares que a estrutura social hierárquica cria com prejuízos para os negros.
}

É possível interpretar que a lei não desconsidera o processo social e histórico de exclusão de direitos da população negra do país. Também leva em consideração a busca de uma mudança que recai no discurso que funciona para o desconhecimento e/ou negação do reconhecimento e valorização dos negros, principalmente, quando cita a desconstrução do mito da democracia racial na sociedade brasileira que funcionou, e ainda funciona, como sustentação do discurso ideológico de que no Brasil não existe o racismo ou que ele já foi superado.

Em 2019, a lei 10.639, completou 16 anos desde a sua implementação; todavia, sua aplicabilidade ainda é questionada no ambiente escolar. A abordagem realizada nas escolas ainda é perpassada por um discurso que ameniza as atrocidades históricas em relação à população negra, tendo em vista que as poucas ações que ocorrem dentro da escola, em sua maioria, acontecem de forma isolada por alguns professores que reconhecem a importância de trabalharem a questão do negro e indígena em suas aulas, por meio da fragmentação do saber e não como tema transversal.

A ausência de elementos necessários para a capacitação e criação de condições de 
trabalho tem contribuído para o despreparo no ensino, em sala de aula. Isso significa dizer que a responsabilidade não deve recair somente em relação à conduta dos professores, pois perpassa o investimento em formação continuada e políticas públicas compromissadas com as questões étnico-raciais.

O aspecto histórico é de extrema relevância ao pensarmos o alcance normativo da lei 10.639. O sujeito-negro nem sempre foi discursivizado como sujeito de sua própria história, tendo em vista o silenciamento da cultura Afro-brasileira e Africana e de como o negro é abordado por uma ideologia que valoriza os padrões apenas eurocêntricos. As raízes culturais trazidas do Continente Africano foram usurpadas e silenciadas. A própria representação dos sujeitos-negros nos livros de História era incompatível, pois por séculos ao invés de nomear a população de "escravizados", inseriu-se o termo "escravo", o que mostra um funcionamento discursivo de um sujeito que já nasce predestinado a esse papel subalterno.

Ainda devido a uma abordagem discursiva racista inclusa nos livros didáticos de História, o contrário de Casa Grande para o Movimento Negro não é local de maior sofrimento do negro, a senzala. A história de resistência durante o período escravocrata não é falada, silencia-se os sujeitos-resistência, pois “(...) por aí se apagam os sentidos que se quer evitar, sentidos que poderiam instalar o trabalho significativo de uma "outra" formação discursiva" (ORLANDI, 1997, p.74), isso porque se quer interditar certas regiões de sentidos, em que o silêncio passa a determinar os limites do dizer.

É com o Movimento Negro que o discurso Casa Grande versus Senzala se esvai, porque o contrário de Casa Grande é o Quilombo. Essa palavra remete ao aspecto de Quilombo de fuga, de resistência, e Quilombo familiar e isso mostra um outro modo de fazer significar a história da resistência negra, ultrapassando o discurso colonizador que objetifica esses sujeitos (GOMES, 2017).

Elencar os efeitos devastadores ocasionados pela escravização dos sujeitos-negros africanos é compreender o efeito discursivo da história na vida de uma população. Acontecimentos como a desigualdade social, políticas de embranquecimento, apropriação cultural, intolerância religiosa e genocídio da população negra são reflexos da dívida latente do país para com os negros e, ainda mais, apontam que a questão racial ainda não foi superada, apenas ganhou novas práticas de coerção.

A violência contra a mulher negra no país, por exemplo, é instigada pelo bombardeio da mídia que discursiviza a hipersexualização do corpo negro. Entender a importância e os 
resultados trazidos por essa legislação é o que permite pensarmos em uma pedagogia das ausências e emergências (GOMES, 2017), sobretudo, uma pedagogia que acredita no diverso e na diversidade, pautada na tolerância (FREIRE, 2018), em que o outro é diferente e é potente nessa diferença e não no discurso de que "todos são iguais", pois:

\begin{abstract}
O preconceito é uma discursividade, que circula sem sustentação em condições reais, mantida por um imaginário atravessado por um poder dizer que silencia sentidos na base do próprio processo de significação. Os mesmos fatos, coisas e seres têm sentidos diferentes de acordo com as suas condições de existência e de produção. No entanto, há um imaginário social que vai constituindo direções para esses sentidos, hierarquizando-os, valorizando uns em detrimentos de outros, de acordo com as relações de força e de poder que presidem a vida social, e a relação com a alteridade. Eles vão fazer com que as diferenças sejam silenciadas em suas especificidades e signifiquem em relação a esse imaginário que administra as relações de sentidos e, logo, as relações sociais e de poder simbolizadas, ou seja, políticas. (ORLANDI, 2017, p. 94).
\end{abstract}

No entanto, sabendo que o sentido sempre pode vir a ser outro (ORLANDI, 2001) e pode ir para outras regiões de sentido, a escola de samba, Paraíso do Tuiuti, origem no Morro do Tuiuti, situada no bairro São Cristóvão, no Rio de Janeiro, fez história no Carnaval 2018, como vice-campeã, ao abordar de forma contundente no seu enredo - Meu Deus, meu Deus. Está extinta a escravidão? - questionando e criticando os maus-tratos dados aos sujeitosnegros escravizados trazendo uma encenação sobre a morte e ressurreição desses sujeitos por meio da representação dos pretos velhos.

Durante a apresentação da escola de samba, a história da escravidão no Brasil foi recontada/denunciada, trazendo uma crítica contundente ao racismo e seus reflexos nas dificuldades enfrentadas, por exemplo, pelos trabalhadores brasileiros na contemporaneidade. O último carro, intitulado, Novo navio negreiro, buscou fazer uma comparação entre os "novos trabalhadores explorados pela classe dominante" e os escravizados do passado, em que elementos simbólicos como mãos acorrentadas, colarinhos brancos e moedas de ouro, compuseram essa analogia, além da polêmica do vampiro com uma faixa presidencial, remetendo a questões da política brasileira recente como a reforma da previdência, a reforma trabalhista, entre outras pautas de políticas públicas.

Esse tipo de demonstração artística garante que a história da população negra não seja silenciada, ainda mais, aponta para a disputa dos sentidos em relação ao modo e direção que será narrada a história dos movimentos de resistência no Brasil, apontando que esses sujeitosresistência continuam protagonizando meios de furar com o discurso dominante acerca dessas 
questões que continuam a borbulhar e a constituir a sociedade brasileira.

O cumprimento da legislação que traz a obrigatoriedade da história Afro-brasileira e Africana recai na importância de se trabalhar a literatura produzida por autores e autoras negras. A cultura negra sendo representada como uma das importantes bases da história brasileira, história essa polissêmica, heterogênea, repleta de contradições.

É nessa busca da garantida legal nas escolas que acreditamos que esta dissertação pode contribuir, em especial, no tocante ao trabalho com a literatura de autoria de mulheres negras na escola, buscando questionar e refletir sobre a política literária e o seu funcionamento que continua interditando as obras de autoria de mulheres negras, tendo em seu cerne o preconceito que é da ordem do silenciamento local, sobretudo, uma forma de censura (ORLANDI, 2017, 95), haja vista que:

O pequeno número de autores afrodescendentes inscritos no cânone literário brasileiro - Machado de Assis (1839 - 1908), Cruz e Souza (1861 - 1898), Lima Barreto (1881 - 1922) - já é uma clara evidência do lugar destinado ao negro em nossa sociedade. Sem acesso à educação e acantonados no limiar da miséria, os afrodescendentes não se constituíram como cidadãos; impedidos de agir como sujeitos da própria história, sucumbiram, pela força da opressão, a meros coadjuvantes da construção de uma identidade nacional. Raros são, até pelo menos o último quartel do século $\mathrm{XX}$, os romances e contos protagonizados por personagens afrodescendentes. (RUFFATO, 2009, p. 12).

Concordamos com Ruffato (2009) nesta citação quando aborda a falta de representatividade de autoras e autores negros e negras no cânone da literatura brasileira, isso devido ao modo como o sujeito-negro foi impedido de ser reconhecido como digno a ocupar a posição discursiva de autor. No entanto, não concebemos como "clara evidência do lugar destinado ao negro em nossa sociedade", porque, conforme abordamos nos capítulos anteriores, a ideologia dominante captura o sujeito não permitindo que ele duvide dos sentidos, sendo assim, o silenciamento da presença da autoria negra na literatura brasileira é um modo de percebermos o mito da democracia racial e o silenciamento do racismo institucional e estrutural funcionando na política literária, que está inserida na vida social.

Maria Firmino dos Reis (1825 - 1917) é considerada a primeira (até que se descubram outras) representações de autoria feminina negra na prosa de ficção brasileira, no romance Úrsula (2014), aparecido em 1859, a autora antecipa, por exemplo, a obra do poeta abolicionista Castro Alves, cuja produção literária vai de 1876 a 1883. Na obra dela, há presença de personagens negros e negras que têm voz e trazem no intradiscurso uma memória 
discursiva atualizada a respeito do passado e do presente de suas vidas, abordando temas como civilização, barbárie, diáspora africana, matrimônio, maternidade, entre outros, que, para época, era uma afronta ainda maior.

É importante ressaltar que Maria Firmino dos Reis é uma escritora menos conhecida do que Carolina Maria de Jesus, visto que na época em que produziu sua obra as condições de produção eram outras. A sua popularidade se dá em pesquisas acadêmicas que tem como foco a autoria negra ou em círculos sociais que formentam esse assunto. Deste modo, a partir do apontamento de 14 pontos que se constituem em motivos de entrave aos estudos acadêmicos sobre a questão racial e promoção de políticas públicas comprometidas com essa causa, Liebig (2003) destaca dois, desses pontos, que dizem respeito diretamente à literatura de autoria negra: 1. A relativa ausência de material didático e fonte bibliográfica sobre o tema, seja em nível de educação básica, ou de educação superior, em consequência da própria decisão do mercado editorial; 2. As dificuldades encontradas na orientação de pesquisas sobre essa temática, além da escassez de professores que trabalham essa questão e possuem formação para essas orientações.

Ao trabalharmos com a literatura de Carolina Maria de Jesus, apesar de ter passado 16 anos desde a publicação acadêmica de Liebig, ainda assim encontramos dificuldades em ter acesso a pesquisas acadêmicas sobre a autoria negra, principalmente, de mulheres, por sua vez, quando o assunto é livro didático, o fosso é ainda maior.

A literatura nos oferece "a oportunidade de apreensão de um imaginário acerca do sujeito-negro na sociedade brasileira" (EVARISTO, 2009, p. 20), é só observarmos a quantidade de obras em que há a presença de personagens negros como protagonistas em relação aos personagens brancos, ainda mais quando isso incide sobre personagens de mulheres negras que tocam nas questões de classe, gênero e raça, pois a condição dos africanos e seus descendentes como "corpos escravos", "objetos a serem usados" no período escravocrata deixou suas consequências no imaginário e organização social até os dias de hoje, produzindo a "visão do corpo negro como 'coisa' desprovida de qualquer subjetividade deixando suas reminiscências na literatura brasileira" (idem, p. 23).

Ribeiro (2017) argumenta que mesmo diante de limites impostos, o do Estado, por exemplo, "vozes dissonantes têm conseguido produzir ruídos e rachaduras nas narrativas hegemônicas (...) fazendo com que essas vozes sejam acusadas de agressivas (...)” (idem, p. 87), justamente porque combatem o silenciamento imposto e promovem uma ruptura no 
sedimentado, como são os casos de Maria Firmino dos Reis e Carolina Maria de Jesus, haja vista que:

\footnotetext{
(...) as várias instâncias do poder se imbricam entre si, como vasos comunicantes, o que permite às classes detentoras e próximas do poder político-econômico serem, elas mesmas, produtoras, mantenedoras, divulgadoras e consumidoras de seus produtos culturais (...). (EVARISTO, 2009, p. 21).
}

É por isso que compreendemos a literatura de Carolina Maria de Jesus como um "ponto fora da curva", capaz de fazer ranger os "vasos comunicantes" pertencentes às classes dententoras de poder, porque gera uma outra formação discursiva que quebra com uma formação imaginária cujo sujeito-negro é inexistente na posição discursiva de autor.

\subsection{Eis-me aqui: Carolina Maria de Jesus}

Farias (2017, p. 242) relata a chegada de Carolina Maria de Jesus em São Paulo, vindo de Franca, interior do estado, em 1937, dizendo que nessa época a densidade populacional ainda não tinha o contorno "centro/periferia". São Paulo tinha cerca de 1.326.261 habitantes e até 1940, os diferentes grupos sociais estavam aglutinados em uma pequena área urbana e se diferenciavam pelo tipo de moradia, mais modestas ou mais ricas. É a partir de 1940 que começam a proliferar as ocupações das regiões do centro, com falta de terrenos livres e custo de vida alto, o que o tornava inacessível para os migrantes.

No contexto em que se insere a primeira publicação e mais famosa dentre a obra de Carolina Maria de Jesus, a população paulistana já contava com 3.781.446 habitantes, isto é, duas vezes mais do que quando ela chegou à cidade. Com a falta de espaço na "pequena área urbana" e de trabalhos decentes, a população ocupou os espaços à margem, periféricos: a favela que, em 1960, já passava a ter por volta de 50 musseques.

Diante disso, podemos observar que Carolina Maria de Jesus gozava de uma popularidade porque havia uma maior concentração de pessoas consumidoras habitando os centros urbanos - as "classes médias e altas" - e também nas periferias da cidade, lugar de onde ela vinha, e "passou a ser, de certa forma, admirada e invejada" (FARIAS, 2017, p. 243).

Em 21 de abril de 1960, Juscelino Kubitschek inaugura Brasília, sua política foi considerada desenvolvimentista resultando em um volumoso crescimento industrial no país, no entanto, neste mesmo governo, houve alta inflação, crescimento da dívida externa e 
problemas relacionados ao campo e à área educacional.

Estados Unidos, Alemanha, França, Itália, Japão, Argentina, Chile, são alguns dos países que tiveram a primeira obra de Carolina Maria de Jesus traduzida. Farias (2017, p. 287) argumenta que o clima das duas corridas eleitorais, americana e brasileira, favoreceram a rápida ascensão de Carolina Maria de Jesus no cume das letras nacionais e internacionais, visto que Carolina se encaixava no "modelo" de denúncia social que estava na esteira do progresso da nação, propalado por Kubitschek - Brasil: 50 anos em 5 -; e por Kennedy “Aliança para o progresso", ainda mais:

\footnotetext{
(...) um mundo que vivia sob o fantasma dos movimentos de reparação social: nos Estados Unidos, com os "Panteras Negras", os direitos humanos e os violentos e sangrentos movimentos antirracistas, liderados pela comunidade negra, os reflexos da revoção não violenta de Mahatma Gandhi, contra as castas na Índia, bem como a forte pressão que pairava a Revolução Cubana em nós e em todo o planeta. (FARIAS, 2017, p. 300).
}

Depois de Kubitschek, em seguida tivemos a eleição de Jânio Quadros (União Democrática Nacional - UDN) para presidente, tendo como vice-presidente João Goulart, da coligação do Partido Social Democrata e Partido Trabalhista Brasileiro (PSD-PTB). Jânio se opunha ao legado político de Getúlio Vargas e ganhou adeptos tanto da classe alta, quanto da classe média, que viam nele uma possibilidade de um governo que combateria a inflação e garantiria a continuidade do desenvolvimento do país.

Gomes e Munanga (2016) ao argumentarem sobre a importância da resistência negra na história do país no combate ao racismo, silenciada ou comentada pouco nos livros didáticos, por exemplo, apontam que houve no início do século XX diversos movimentos de resistência negra, a começar pela Revolta da Chibata, movimento naval no Rio de Janeiro liderado por um homem negro, João Cândido, em 1910.

Depois, fundado em 16 de setembro de 1931, a Frente Negra Brasileira, foi um movimento de organização política que surgiu a partir de militantes negros paulistas pósabolição, reconhecido como partido político em 1936, que desenvolveram um significativo trabalho socioeducativo e cultural combatendo um período em que vigoravam as teses do racismo científico (eugenia), sustentadas na ideia de que negros compunham uma raça inferior.

Por sua vez, surgiu o Teatro Experimental do Negro - TEN - (1944 a 1961) cujo objetivo era a educação como forma de cidadania para a população negra, tendo o teatro e as 
artes como meios de expressão cultural e política e, por fim, o Movimento das Mulheres Negras que começaram a articular classe, raça e gênero dentro ds relações étnicas/raciais na sociedade brasileira, atuantes até hoje.

Também em 1960 temos em funcionamento no país da televisão, com 200 mil receptores de televisão desde a sua pré-estreia, em 3 de abril de 1950, com a apresentação do padre Frei José Mojica realizada somente no saguão dos Diários Associados de Francisco Assis Chateaubriand, que comprou os equipamentos dos Estados Unidos.

Isso indica que além dos rádios, jornais e revistas, a televisão também foi uma mídia importante na divulgação da obra de Carolina Maria de Jesus, que participou de diversos programas na época, porque se tratava de uma matéria (assunto) que conquistava altos ibopes, devido a curiosidade que era estabelecida em relação à essa escritora exótica:

Carolina passou a ser exposta, diariamente, pela imprensa falada, escrita e televisionada. A partir da década de 1960, exatamente no ano do grande "boom" de Carolina, a TV, inaugurada dez anos antes, chegava a atingir uma grande audiência tanto na população alfabetizada quando analfabeta, se tornando o "meio preferido das agências de publicidade". No caso da Carolina, ela usufruiu de um dos meios de comunicação, o qual marca o "acesso da elite econômica brasileira ao televisor (década de 1950 - 1960), considerado um luxo" para a sociedade brasileira. (FARIAS, 2017, p. 216).

Carolina Maria de Jesus ocupa a posição de sujeito-autor dentro de todo esse contexto sócio-histórico-ideológico, em que a voz dos sujeitos-negros, dentro e fora do país ganham estatuto político.

Nos Estados Unidos, Rosa Louise McCauley, conhecida como Rosa Parks, em 1 de dezembro de 1955, em Montgomery, estado do Alabama, recusa-se a ceder seu lugar no ônibus para um homem branco que exigia que ela se retirasse para ele sentar, pois naquela época a segregação racial era permitida pelas leis norte-americanas, principalmente, nos estados do sul.

No Brasil, Carolina Maria de Jesus, na década de 60, torna-se a autora mais vendida do país, por meio de uma escrita de enfrentamento social, não sem contradições, a partir de um enredo do "lixo", daquilo que ninguém queria ver e "inaugura" a visibilidade da escrita literária de autoria de mulheres negras periféricas.

Liebig (2003) argumenta que o caso de Carolina Maria de Jesus na literatura abriu um precedente na história literária do país, primeiro por causa do lugar de enunciação da autora (favela) e sua condição mulher, mãe, pobre, negra; segundo porque sua escrita abriu 
possibilidades para que outras mulheres negras se sentissem autorizadas a também ocuparem a posição discursiva de autoras de literatura, como Francisca Souza da Silva em, Ai de Vós! Diário de uma doméstica (1983), que tinha um estilo de escrita parecido com o de Carolina.

Para essa autora (2003, p. 140-141) Carolina Maria de Jesus, internacionalmente, foi marcada mais pela questão da raça do que pela questão de ser mulher, em meio a um cenário onde o sujeito-negro ascendia socialmente, ou na carreira como cantor de pagode, ou como desportista. No entanto, o peso da Ditatura Militar, de 1964, fez acordar uma censura explícita, em que a voz dos subalternos não tive mais garantia de espaço, por sua vez, diz ainda que em nossa sociedade, a exemplo de muitas outras “(...) as classes dominantes procuram sufocar manifestações culturais das outras classes através de um processo de padronização que desemboca na exclusão" (LEIBIG, 2003, p. 143). Assim, certos protestos ou modos de resistência vindo das minorias passam a ser vistos e rotulados pela elite como um "problema da falta de cultura", na tentativa de manutenção da relação de dominação.

Para Leibig, a escrita de Carolina Maria de Jesus só tomou as proporções de visibilidade por conta da recém inaugurada televisão, na época, que conseguiu encurtar a distância entre a autora e o grande público, ainda assim com contornos estranhos. Apoiada em Meihy, Leibig argumenta que Carolina ficou famosa sem perder o lastro de miserabilidade, pois, por mais paradoxal que seja, as obras posteriores dessa autora não tiveram o mesmo destino do seu primeiro livro, já que:

\begin{abstract}
A razão disso é que o Quarto (grifo da autora) se constitui num texto que, em nível de Brasil, só se explicaria no espaço e no tempo em que foi publicado. Só teria razão de existir (no contexto da cultura brasileira) no momento político e cultural do florescimento da democracia e da contracultura. Elas implicavam, em conjunto, a definição das minorias e com ela a expressão política dos grupos envolvidos. (LIEBIG, 2003, p. 138).
\end{abstract}

Carolina Maria de Jesus, assim como Rosa Parks, desafiam o "semanticamente estabilizado" (PÊCHEUX, 2009), com seus gestos - uma pela escrita e a outra pela recusa de levantar-se da poltrona de um ônibus - deslizando para outros sentidos de desidentificação, isto é, deslizam para outra formação discursiva que resiste discursivamente ao discurso dominante sobre a inferioridade do negro, possibilitando percursos de sentidos não experimentados, é “o imponderável, o impensável”, o sentido fazendo um sentido outro.

Ideologia e inconsciente cumprindo seu trabalho simbólico" (ORLANDI, 2017, p. 99), temos no gesto de resistência o silenciado significado, na produção do sentido a partir do não- 
sentido, ruptura com o estabilizado, pois “onde há censura há resistência” (ORLANDI, 1997), por isso o lugar do sujeito-negro no ônibus público é onde ele quiser, assim como na escrita.

Na publicação da primeira obra de Carolina Maria de Jesus - Quarto de Despejo: diário de uma favelada (2014) - ao mesmo tempo em que a venda foi um sucesso, pois em um único livro mais de um milhão de cópias vendidas, traduzidas para 13 idiomas e distribuída para cerca de quarenta países (FARIAS, 2017), houve, também, uma contracorrente de críticos (jornalistas, escritores, professores, entre outros) que interditavam a obra questionando a sua qualidade, inclusive, duvidando da autoria, pois essa vendagem causou uma ruptura no "semanticamente estabilizado" (PÊCHEUX, 2009), visto que uma mulher, negra, pobre, favelada, ter sucesso de vendas em detrimento, por exemplo, de Jorge Amado, com Gabriela, cravo e canela; Reflexões sobre o racismo, de Jean Paul Sartre, entre outros, era uma afronta.

Figura 4 - Relação dos livros mais vendidos do Jornal Folha de São Paulo, agosto de 1960, que perdurou até o ano seguinte

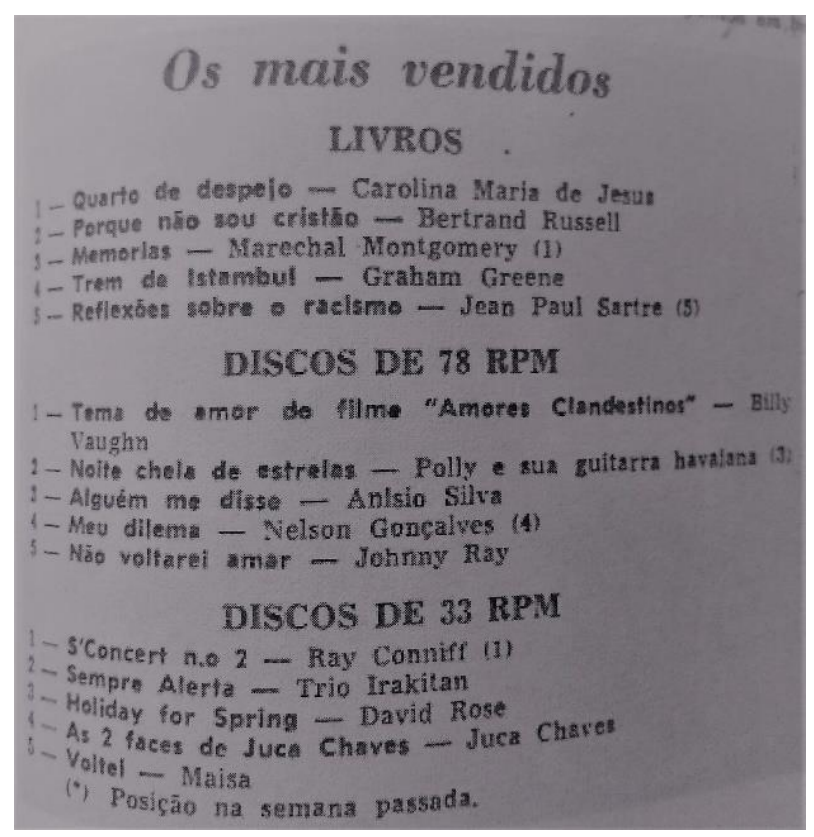

Fonte: FARIAS (2017)

Em uma semana de lançamento da obra de Carolina, em 1960, já tinham sido vendidos 10 mil exemplares, esgotando a primeira edição, algo inédito em uma época em que a venda de um lançamento atrelado ao nome de um autor já consagrado girava em torno de 200 cópias na primeira edição, tendo Jorge Amado superado esses números ao vender 500 cópias na primeira edição de Gabriela, cravo e canela. Carolina, "o livro da autora favelada", 
vendeu 2000 exemplares por dia (FARIAS, 2017, p. 229), deste modo:

\begin{abstract}
Não era por menos a implicância da crítica dos "literatos" com o sucesso de Carolina. A escritora mineira não era só a mais vendida do país, ou o best-seller incontestável, mas também a mais paparicada e requisitada das autoras brasileiras pela imprensa e as rodas sociais. Isso incomodava, e muito. Os articulistas de plantão, com isso, só tratavam Carolina de "escritora favelada" ou de "autora favelada", e erravam seu nome, muitas vezes propositalmente - chamando-a de "Maria Carolina" ou simplesmente - "Maria de Jesus". (FARIAS, 2017, p. 230).
\end{abstract}

Podemos notar que o nome de autor de Carolina valia não como Carolina Maria de Jesus mas, antes, valia por meio da nomeação "escritora/autora favelada", ou seja, a nomeação adjetivada "favelada" precisava funcionar nos discursos sobre a autora, desde os críticos que a "boicotavam", até o discurso da imprensa atrelado ao mercado, isto é, Carolina, a partir da posição de sujeito-autor só era legitimada se a adjetivação "favelada" viesse antes ou junto do seu nome próprio, como se esse termo fosse o seu nome de autor.

Isso indica o quanto a legitimação, nesse caso concedida pelo mercado, no funcionamento da política literária, aponta as suas rasuras e opacidades, em que, para alguns sujeitos, a legitimação se dá por meio de um processo repleto de interdição, preconceito, discriminação; contudo e, sobretudo, de enfrentamento e resistência.

Figura 5 - Carolina Maria de Jesus, agora, "sofisticada"

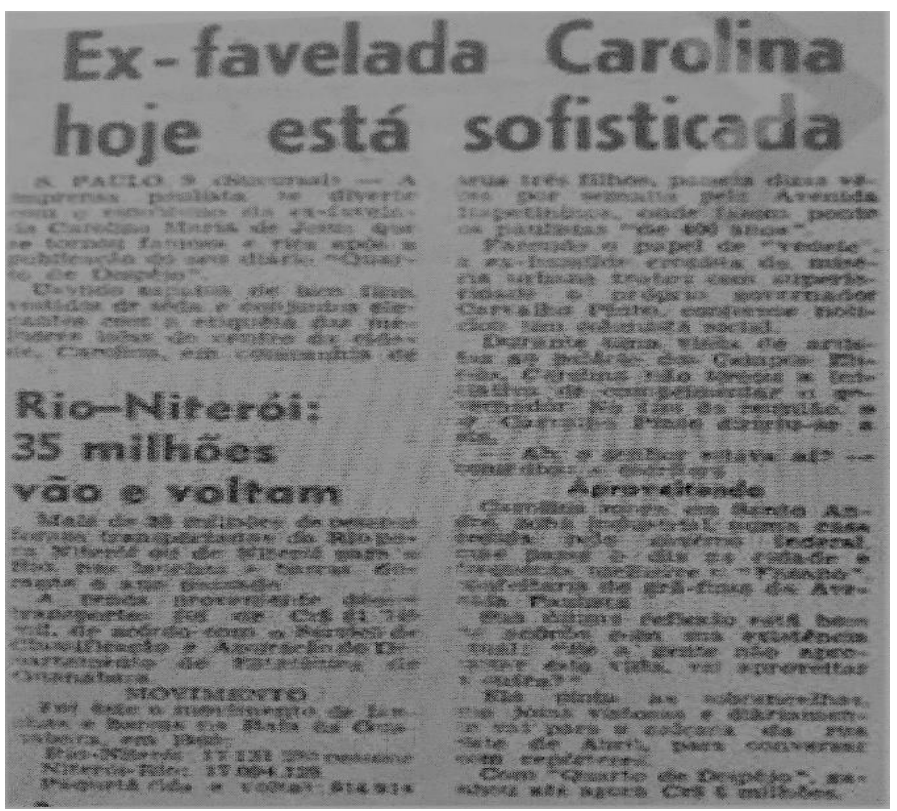

Fonte: (FARIAS, 2017, p. 364). 
Figura 6 - Carolina, cercada de crianças da favela de Canindé, muitas descalças, levadas ao lançamento numa Kombi patrocinada pelo jornal Última Hora, de São Paulo

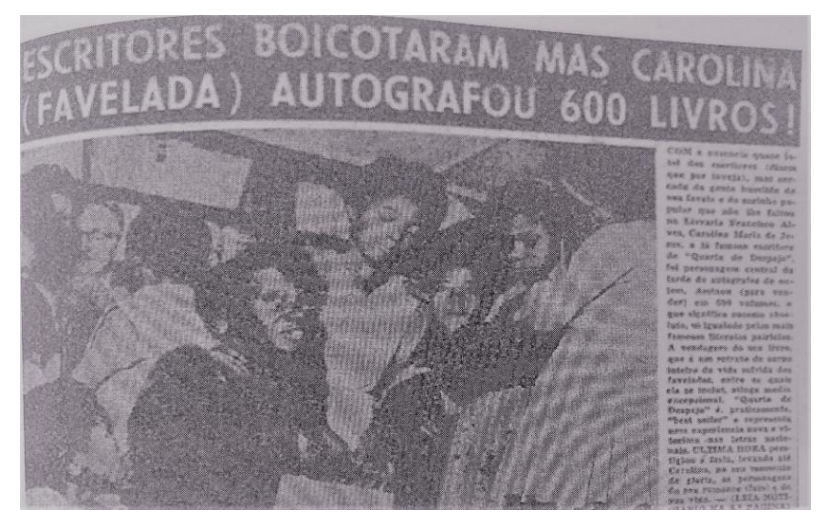

Fonte: FARIAS (2017)

Figura 7 - Carolina Maria de Jesus ao lado do ministro do trabalho, no dia do lançamento do seu livro

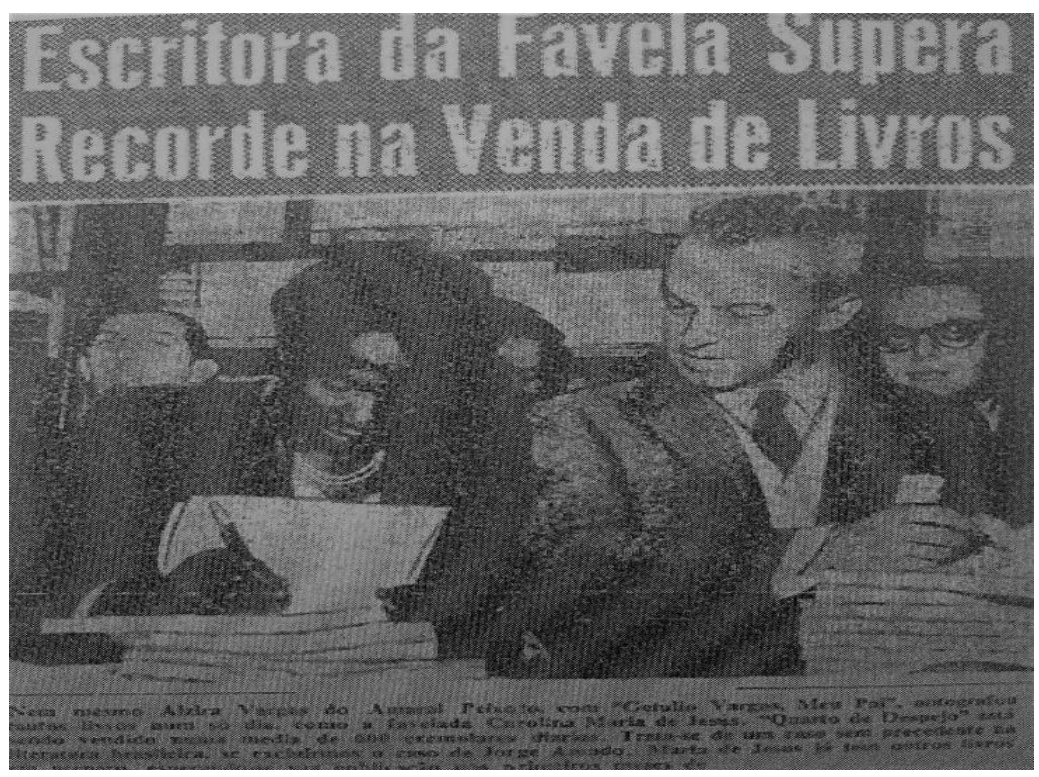

Fonte: FARIAS (2017)

Figura 8 - Uma das primeiras reportagens anunciado o livro de Carolina, saiu no jornal Última Hora, SP, de 06 de maio de 1960 


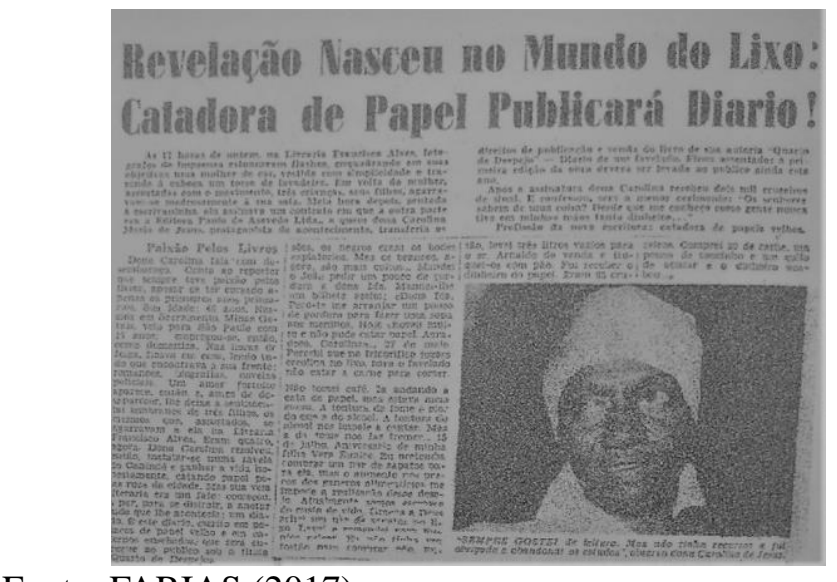

Fonte: FARIAS (2017)

Nas manchetes de alguns jornais é possível observar o modo como discursivizaram Carolina Maria de Jesus: "Ex-Favelada Carolina Hoje Está Sofisticada"; "Escritores Boicotaram mas Carolina (Favelada) Autografou 600 Livros"; "Escritora da Favela Supera Recorde de Vendas"; "Revelação Nasceu do Mundo do Lixo: Catadora de Papel Publicará Diário".

Não faremos uma análise do corpo-textual da notícia, apenas das manchetes. Se nas duas primeiras manchetes o nome de Carolina está posto (não por completo), por sua vez, nas duas outras nem é citado.

$\mathrm{Na}$ primeira manchete, antes do nome Carolina vir proununciado, "Ex-Favelada" é marcado, como se Favelada fosse parte do nome próprio da escritora, aliás, "Ex-Favelada", porque tornou-se "sofisticada", o que funciona aí? Ironia? Sofisticada por que agora tem condições financeiras diferentes das que vivia na favela? Ou porque ocupar a posição sujeitoautor, ainda mais publicizado e com fama, é atingir esse patamar do requintado socialmente? Se Carolina é "EX-favelada" importa dizer que esse estigma sempre lhe acompanhou, mesmo junto ao "sofisticada".

A segunda manchete aponta o descrédito por parte de escritores que "boicotaram" o lançamento do livro de Carolina, também marcando entre parênteses a "Favelada", afrontando o mercado editorial com a vendagem de 600 livros autografados. Acontecimento histórico que merece ser registrado em um jornal, afinal, não são todos os dias que se vê um autor negro, ainda mais mulher e periférica, discursivizada nesse lugar, a de sujeito-autor.

Também fica-nos a pergunta: será que os escritores realmente a boicotaram? Ou foi uma falácia jornalística a fim de promover a contenda? Boicote ou não, a quais escritores o jornal se refere? Para Farias $(2017$, p. 221) tratava-se dos escritores consagrados da época que 
não foram ao lançamento, intencionalmente. Temos a política literária funcionando nesse jogo pendular dos legítimos e dos interditados, na voz do jornal que contribui para a disputa de poder sobre quem pode mais na literatura.

Ainda nesse jornal é interessante observar que "pela primeira vez uma livraria foi invadida pelo povo" (FARIAS, 2017, p. 221), neste caso, com a intenção da jogada de marketing, em que o jornal Última Hora, de São Paulo, buscou, na favela onde morava Carolina Maria de Jesus, alguns moradores a fim de participarem da sessão com a escritora. Fazendo uma comparação, ainda hoje a livraria não é o lugar do sujeito-periférico, a começar pelos altos custos que o livro tem no país e depois porque esse espaço foi organizado para receber um determinado público (classe média e alta), visto que importam os sujeitosconsumidores apenas.

Ao voltarmos para as manchetes, na terceira delas, o nome de Carolina Maria de Jesus nem aparece, no entanto, Favelada é marcado, indícios do descrédito do nome próprio do autor. Essa questão é recorrente e importante porque, na contemporaneidade, a escrita de Carolina ainda é colocada nesse imaginário "escritora favelada que trata da favela" e isso produz um reducionismo em seu vasto acervo e também o desinteresse das editoras em publicar escritos dessa autora que fogem do enredo da favela.

Faz parte da política literária levar em conta a história (biografia) das autoras e dos autores porque, como já abordamos, a literatura ainda é discursivizada no plano da estética/estilo do autor, isso é possível de ser verificado, por exemplo, nas contracapas ou aberturas de obras literárias, em sites de pesquisa sobre literatura, revistas, jornais e nos livros didáticos, na ilusão de que nos escritos dessas autoras e autores é possível detectar marcas que possibilitam estabelecer analogias com passagens de suas vidas, seja para o bem ou para o mal.

No caso de Carolina Maria de Jesus, sua primeira obra só é o que é - famosa, vendável - porque foi lida por muitos não como literatura, mas como relatos verídicos de alguém, acoplados à ilusão de transparência da linguagem, sendo assim, importa a obra porque antes há o interesse por quem escreveu, sujeito-exótico, voz de quem estava dentro da favela e não fora, tanto é que outras obras e enredos da autora não ganharão a mesma popularidade, já que Carolina interessa(va) ao público leitor apenas na posição de "A Favelada". Para o mercado editoral isso é um ponto primordial e necessário porque funciona como discurso de propaganda que faz vender. 
Na quarta manchete, novamente, o nome próprio da autora não é explicitado e, além de “A Favelada", outras nomeações são materializadas "A Lixeira", "A Catadora de Papel”, também funcionando nessa linha tênue da legitimação (Carolina Maria de Jesus está em destaque) e da deslegitimação (escritorazinha sem nome próprio, menor, marginalizada).

Não significa que queremos negar, sequer apagar o lugar de onde Carolina veio, a favela, pelo contrário; está aí a possibilidade da polissemia, do novo, das rupturas, do sentido vir a ser outro. Todavia, a obsessão dos meios de comunicação em discursivizar o tempo todo o fato de essa autora ter vindo da favela, funciona, a nosso ver, para dar destaque a sentidos que construíssem efeitos de estranhamento, exotificado, reconhecido como menor, portanto, estigmatizado, produzindo o "compartimento discursivo da literatura", conforme já abordamos, isto é, a produção de uma formação discursiva que sedimenta e fixa um modo de fazer significar a autoria dessa escritora, como um “(...) produto "vendável” do jornalismo noticioso e sensacionalista, que tinha nela a garantia de audiência certa, como objeto de consumo e curiosidade" (FARIAS, 2017, p. 217), peça publicitária da Livraria Francisco Alves que percebeu o alcance midiático da autora como “(...) elemento estranho, provocando a curiosidade pública e também a comiseração por sua história de vida” (idem, 2017, p. 217).

Farias (2017) ao tratar sobre a crítica nacional da primeira publicação literária de Carolina Maria de Jesus mostra que, se de um lado Carolina era recebida com elogios e aplausos por muitos críticos que reconheciam a força de sua palavra e da sua posição de sujeito-autor, por outro, houve uma avalanche de críticas negativas, impiedosas e, de certo modo, apoiadas no discurso racista.

Carolina incomodava porque era lida, ainda mais, porque vendia. Tratava-se de uma condição de produção em que, ao mesmo tempo que a legitimação e a visibilidade era posta, por outro, a força do silenciamento vinha com tudo na tentativa de impedir, se não a circulação da obra de Carolina, o seu crédito como sujeito- autor.

As críticas positivas (FARIAS, 2017, p. 238) pautavam-se, em geral, a respeito do potente discurso de uma voz subalterna em ocupar a posição de sujeito-autor e produzir sentidos sobre um lugar que "ninguém queria ver", a favela. Paulo Dantas, diretor da Livraria Francisco Alves, disse que ninguém superava a voz de Carolina, que "brotava de dentro e nascia", já Helena Silveira, pertencente a uma família de escritores e prima de Raquel de Queiroz, comenta que Carolina tinha nascido "contadora de histórias" e, na sua opinião, questionava "O que faz e o que obsta o escritor? Há receita para ingressar nesse ingrato mundo de 
contadores de histórias?", pois para ela o preconceito contra a escrita de Carolina vinha do fato de ela ser favelada e mulher.

Em relação às críticas preconceituosas que eram dadas à obra de Carolina, Graciliano Ramos, autor legitimado da Literatura Brasileira, disse que "Carolina Maria de Jesus escreve com sangue, com lágrimas, os seculares materiais da advertência”, por sua vez, Manuel Bandeira é foi questionado e pressionado pelos seus pares a respeito da sua admiração pela obra de Carolina “de meia instrução primária” e disse:

\begin{abstract}
Muita gente me tem perguntado se acredito na autenticidade do livro. Querem atribuí-lo a trabalho de Audalio Dantas sobre notas, apontamentos de Carolina. Houve de fato algum trabalho de composição da parte de Audalio. Este declarou no prefácio que selecionou trechos dos cadernos de Carolina, suprimiu frases. Mas não enxertou nada. Acredito. Há nestas páginas certos erros, certas impropriedades de expressão, certos pedantismos de meia instrução primária, que são de flagrante autenticidade, impossíveis de inventar. (FARIAS, 2017, p. 240).
\end{abstract}

Após a declaração de Bandeira, ou concomitante ao parecer dele, outros como Ferreira Gullar, Edgard Braga, Adonias Filho, Eneida, Ricardo Ramos, Lúcia Benedetti, Carlos Pinto Alves, e muitos outros, escrevem sobre a relevância da narratividade enfeixada por Carolina, editada pela Livraria Francisco Alves, em que a ideia da miséria era dada "pela mão da miserável" que impactava a sociedade (FARIAS, 2017, p. 241).

Há no depoimento de Bandeira um dado muito importante, ainda mais para nós analistas de discurso, que é em relação ao modo como a obra - Quarto de Despejo: diário de uma favelada (2014) - foi editada, por meio da intervenção de Audalio Dantas, jornalista que descobriu Carolina e seus cadernos na favela de Canindé, em São Paulo, isso porque há uma interferência do jornalista na autoria de Carolina.

Audálio Dantas relata que encontrou Carolina Maria de Jesus na favela de Canindé, São Paulo, enquanto produzia uma matéria sobre esse lugar. Curioso com aquela mulher que dizia em voz alta que colocaria as pessoas que a incomodavam em seu livro, o jornalista pediu para a escritora que mostrasse seus escritos e foi, assim, que descobriu uma grande autora "que logo se colocou como alguém que tinha o que dizer".

Segundo o prefácio da obra, Dantas diz que a fome para Carolina Maria de Jesus tinha cor - a Amarela. Ele salientou que por "excessiva presença, a Amarela saiu de cena" e, também, que foi preciso alterar a pontuação, assim como algumas palavras cuja grafia poderia levar à incompreensão da leitura do livro. E para encerrar, o prefaciador escreve que foi só, até a última linha. 
Essas interferências do jornalista são marcas de uma relação desigual de poder (o jornalista e a favelada) e violentam a autoria dessa escritora, afinal, a fome é personagem central nesta obra; a fome é insistente, miserável, praga, contumaz, portanto, faz parte da poética da autora a repetição, assim como sua singular grafia das palavras e a pontuação.

$\mathrm{Na}$ obra, a fome tem dimensões que ultrapassam a questão apenas da falta de acesso aos alimentos, ou à pobreza em geral, pois é possível observar a presença de uma outra fome, a saber, a da escrita. Temos um sujeito-autor que escreve sobre a fome porque sente, metaforicamente, a fome de materializar pela escrita as suas fomes: a fome da escrita e a escrita da fome.

Isso indica um modo de funcionamento do próprio mercado que, apoiado na mídia sensacionalista do ibope, tende a selecionar a escrita que vende. Deste modo, tudo indica que as partes selecionadas pelo jornalista se renderam ao desejo mercadológico (ilusão da unidade discursiva, do sensacionalismo, do lucro), pela atitude violenta em relação à interferência na autoria de Carolina que, certamente, na posição de sujeito-autor, constitui-se pela repetição tão necessária de uma "fome" que nunca cessa (trataremos mais desse assunto nos próximos capítulos) em meio a um cenário de miséria humana.

Outra questão que nos chama a atenção é em relação à escrita de Carolina Maria de Jesus que, até hoje, começo do século XXI, continua a incomodar, apesar dos avanços nos estudos sobre preconceito linguístico (BAGNO, 2007); letramento e autoria (PACÍFICO, 2002; TFOUNI, 2012); entre outros, em que a questão da linguagem é colocada em cena, ainda há um modo de interdição funcionando por meio desse discurso do "não sabe escrever corretamente", portanto, não sabe "pensar e se expressar", mito que Bagno (2007), em seus estudos, contesta e desmistifica. Diante disso:

\footnotetext{
Carolina foi vítima da perseguição da língua por um "intelligentsia" supostamente ditadora de regras culturais da língua falada e escrita, mas como uma imposição de critérios e condutas, na forma de dominação, algo canônica, garantidora de hegemonia de uma casta, de um pequeno e seleto grupo encastelado no "poder das letras", diga-se de passagem, já predominantes na cultura e na política do país, por longos séculos. (FARIAS, 2017, p. 237).
}

Essa ilusão da transparência da linguagem e do controle do sujeito em relação ao seu discurso, modos de conceber o simbólico que funcionam na política literária como justificativa para a desqualificação preconceituosa e discriminatória de certas autoras e autores em relação ao modo como esses sujeitos produzem, pela materialidade linguística, os 
seus discursos literários.

Farias (2017, p. 236) comenta na biografia de Carolina Maria de Jesus que ela era uma leitora de dicionários gramaticais ou de prosódia e, durante o seu sucesso com a publicação do primeiro livro, chegou a ter professores de língua portuguesa, visando a melhorar o seu idioma, o que pode ser notado nas suas publicações posteriores ao seu livro de 1960. Era preciso jogar o jogo da política literária, cuja legitimação passava pelo crivo da escrita da norma-padrão da língua portuguesa, afinal, não se consegue fazer parte do "castelo" sem seguir os padrões.

É como se valesse apenas a escrita dos autores que "cultuam a forma", como os parnasianos, por exemplo, em detrimento de outros modos do dizer. É importante pensarmos que poetas modernistas, como Oswald de Andrade, já haviam produzido um discurso poético a respeito do preconceito linguístico:

\author{
Vícios na fala \\ Para dizerem milho, dizem mio \\ Para melhor dizem mió \\ Para pior pió \\ Para telha dizem teia \\ Para telhado dizem teiado \\ E vão fazendo telhados \\ (ANDRADE, 1978, p.47).
}

Se o mercado editorial interpreta em Carolina Maria de Jesus um produto de consumo de sucesso, junto com a mídia (televisiva, jornais, revistas etc), cria-se um sujeito-autor, a partir das formações imaginárias, que provoca e incomoda uma grande parcela da sociedade, afinal, quem é você (favelada) para se constituir como autor? Ainda mais quando esse sujeito-autor é capaz de "bagunçar" o(s) conceito(s) de literatura(s) e, consequentemente, de cânone, pois abre um caminho de possibilidades discursivas para outros modos (polissêmicos) de (re)pensar sobre essas questões.

No entanto, não podemos associar o jogo discursivo do mercado em relação ao modo como a academia, por sua vez, a escola, concebe a literatura, pois o primeiro visa ao lucro, o que significa que ao mesmo tempo que funciona legitimando um autor e sua obra, por outro lado, não se responsabiliza por essa legitimação que pode, facilmente, ser silenciada, abandonada, basta que o mercado editorial "feche suas portas" para as obras e os autores que passam a não vender, isto é, a dar lucro.

Já no segundo caso, por causa da academia e a escola serem vozes de autoridade, são 
imprescindíveis a responsabilidade e o cuidado que se deve ter nesse jogo discursivo da política literária em sucumbir a um conceito de literatura que, pautado na paráfrase, impede o direito às literaturas, atrelado a uma visão, conforme já mostramos, de confronto em relação às obras nomeadas de "entorpecentes".

Os discursos de escamoteação da primeira publicação de Carolina Maria de Jesus foram diversos em que muitos críticos, ferinos, tentavam despistar o sucesso da autora ou confundila diante da opinião pública.

Um crítico que assinava por "Casmurro de Assis", pseudônimo de quem não consegue responsabilizar-se pelo seu dizer, classifica a obra de Carolina como "panfleto murmurando em voz mansa e cordial, voz humilde de criatura", em que, "O perigo é que Carolina Maria de Jesus queria se tornar escritora".

Herculano Pires, irado e irônico, disse que Audalio Dantas era um "mensageiro de Deus" e chega a dizer que o "livro da favelada, este diário da miséria e marca da vergonha" deveria ser “incluído na Bíblia”.

Sério Porto, famoso ao usar o pseudônimo Stanislaw Ponte Preta troca o nome de Carolina por "escritora favelada, mais favelada do que escritora"; outro articulista, assinou como "Christina" e aconselhou Carolina, dizendo "Só desejo que essa mudança tão súbita e brusca não lhe roube a espontaneidade, a autenticidade, não a faça levar longe demais as suas ambições literárias" e segue dizendo que a obra da escritora era apenas um livro de relatos e não uma obra literária em que "Se por ventura Carolina conseguir, pelo estudo e pelo esforço, o domínio desse meio de expressão, então poderá considerar-se uma escritora no sentido exato da palavra" (FARIAS, 2017, p. 229-232).

Todos os discursos citados no parágrafo anterior mostram o funcionamento da interdição da política literária em relação a um autor que rompe com o imaginário esperado sobre o que faz um indivíduo constituir-se como um sujeito-autor (ideal).

São formações discursivas e ideológicas que propagam um modo de (re)conhecer a escritura de Carolina Maria de Jesus, na posição de sujeito-autor, deslegitimando-a. É interessante observar que muitos desses discursos são materializados por sujeitospseudônimos, não no sentido de outros modos do dizer, como em Fernando Pessoa e seus heterônimos, ou em Clarice Lispector, que utiliza o pseudônimo de Helen Palmer, no Correio da Manhã, ou como Teresa Quadros, no Entre mulheres, por não se identificar com a função dada a ela nessas colunas, mas são sujeitos que não querem ter a responsabilidade pelo seu 
dizer sustentada em discursos racistas e colonialistas.

Nas críticas apresentadas, Carolina Maria de Jesus, na posição de sujeito-autor é discursivizada como "criatura mansa", "A Favelada", que produz não uma obra literária, mas, um "panfleto", "diário de relatos" que merecem fazer parte da "Bíblia", ironicamente, isto é, escrita "sagrada", do sujeito miserável que suplica piedade perante a sua vida de "criatura", portanto, sentidos que colocam esse sujeito-autor na subalternidade, como literatura menor que precisa ainda "provar" que merece a "medalha" de autor pelo "estudo" (como se a escola fosse a garantia de saber "escrever bem") e "esforço", discurso da meritocracia, tão presente na nossa contemporaneidade.

A escrita de Carolina Maria de Jesus é reconhecida pela crítica como "espontânea", discurso muito presente na escola perante a escrita dos sujeitos-alunos que não conseguem produzir o "molde" que essa instituição lhes impõe. A escrita "espontânea" é discursivizada, muitas vezes, sobre os sujeitos-marginalizados ou a obras literárias em que a linguagem não apresenta certos "rebuscamentos vocabulares" e, nesse jogo preconceituoso linguístico, tendem a ser interditados e/ou desvalorizados. O sujeito-autor da escrita "espontânea" não pode ser considerado um autor de verdade, sendo assim, não tem o direito de ter "ambições literárias", seja o que for que se queira dizer com isso.

Outras críticas continuaram em relação à Carolina Maria de Jesus e sua primeira publicação, uma delas não se identifica no jornal A Tribuna, na seção Livros novos, diz que Carolina trata-se de uma "Mulher de cor, semianalfabeta (...) narra ou registra miúdos incidentes da "favela" onde vive", completando que "O texto sem gramática, de forma desordenada, somente se ocupa de coisas imediatas (...) abandonadas pelos poderes públicos e religiosos do país", por fim diz que "O livro, que está obtendo o mais êxito publicitário, e dando dinheiro a ganhar à morfina "escritora"”. (FARIAS, 2017, p. 232-233).

Mais uma vez a questão gramatical da escrita de Carolina é coloca em cena em que se interpreta a obra dessa escritora como "registros incidentais", de uma "mulher de cor" e sua vida na "favela".

A expressão "mulher de cor" é importante de ser observada, pois implica pensarmos naquilo que hooks (2019) defende como "imagens libertadoras", que permitem às mulheres negras não serem vistas e discursivizadas a partir de uma "estética da supremacia branca". Por supremacia branca deve-se compreender as narrativas culturais e a produção de conhecimento que partem do ponto de vista de pessoas brancas. A estética da supremacia 
branca "oferece audiência os mesmos velhos esteriótipos negativos de mulheres negras" (hooks, 2019, p. 27) portanto, enxerga e impõe às mulheres negras uma "imagem" carregada de preconceito e discriminação.

O sujeito, ao materializar a sua crítica em relação à Carolina, marca a questão da pele mulher de cor - o que indica que não é só o fato de ser uma "escritora favelada", mas também por se tratar de uma autora negra que incomoda tanto. É como se fosse exótica a existência de mulheres negras autoras. Isso é fundamental para observarmos o modo como o racismo funciona, afinal, os sentidos não são os mesmos quando se discursiviza sobre Anne Frank e o seu diário, em que não se diz "A mulher branca autora, Anne Frank”.

Essa questão dos corpos negros que incomodam podem ser observados nas feiras literárias e congressos acadêmicos, em que muitas mulheres negras só são convidadas a participarem desses eventos se o tema discutido estiver ligado a questões étnico-raciais, é como se elas não tivessem o direito e a capacidade de também participarem de discussões sobre, por exemplo, Clarice Lispector ou Fernando Pessoa.

Nomear mulher negra ao invés de "mulher de cor" ainda é um problema no Brasil. Pretinha, escurinha, mulatinha, moreninha, são expressões muito utilizadas, porque há uma formação discursiva que não consegue questionar ou estranhar os sentidos que essas formulações podem ter, pois dizer negra é um desconforto por conta de todo um processo sócio-histórico-ideológico que sempre procurou fazer circular sentidos de inferioridade, desprezo, feiúra, violência, selvageria, entre outros.

O termo "negra”, no dicionário Michaelis, de Língua Portuguesa diz:

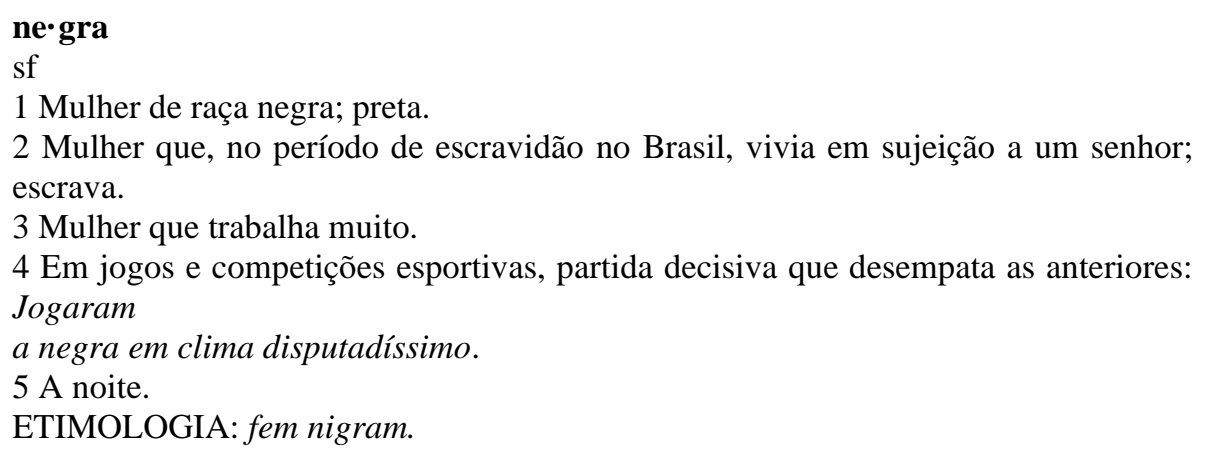

Pode-se observar que o dicionário também não ajuda a fazer significar o termo "negra" de modo que fuja dos sentidos atrelados a escuridão (noite), escravidão e subalternidade. A mulher negra é discursivizada como aquela que trabalha muito, imagens, no sentido de formações imaginárias, que não garatem a libertação dos estereótipos proposto por hooks 
(2019), isso porque os dicionários registram a língua em uso pela sociedade, portanto, é pelo social-histórico-ideológico que se marca tal significados/sentidos neste meio.

Até mesmo o exemplo dado pelo dicionário "Jogaram a negra em clima disputadíssimo" nos remete a pensar nos sujeitos-negros escravizados, vendidos (jogados, disputados) como mercadorias e tratados como objetos, no período colonialista, o que é possível verificar nos anúncios publicitários abaixos:

Figura 9 - Anúncio publicado no Correio Paulistano, em 05 de junho de 1862.

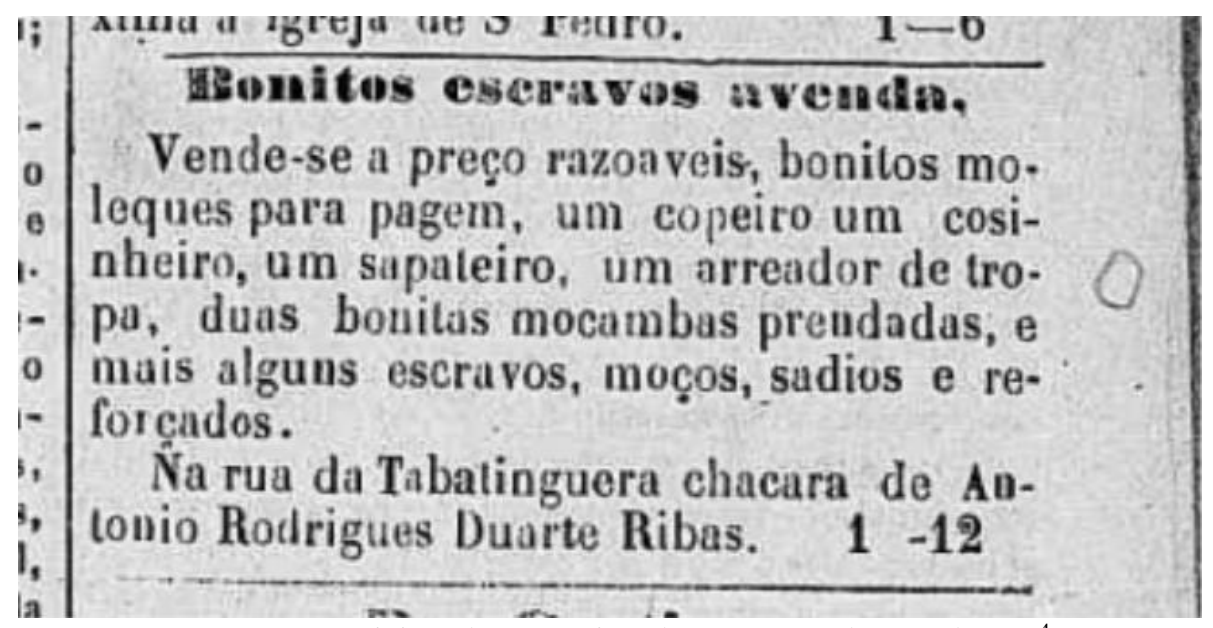

Fonte: LOPES, D. Revisitando anúncios de escravos do século $19 .^{4}$

\footnotetext{
${ }^{4}$ Disponível em: < https://www.vice.com/pt br/article/8x53y3/revisitando-anuncios-de-escravos-do-seculo-19>.
} Acessado em 19 de maio de 2019. 
Figura 10 - Anúncio publicado no Diário de Pernambuco, em julho de 1866

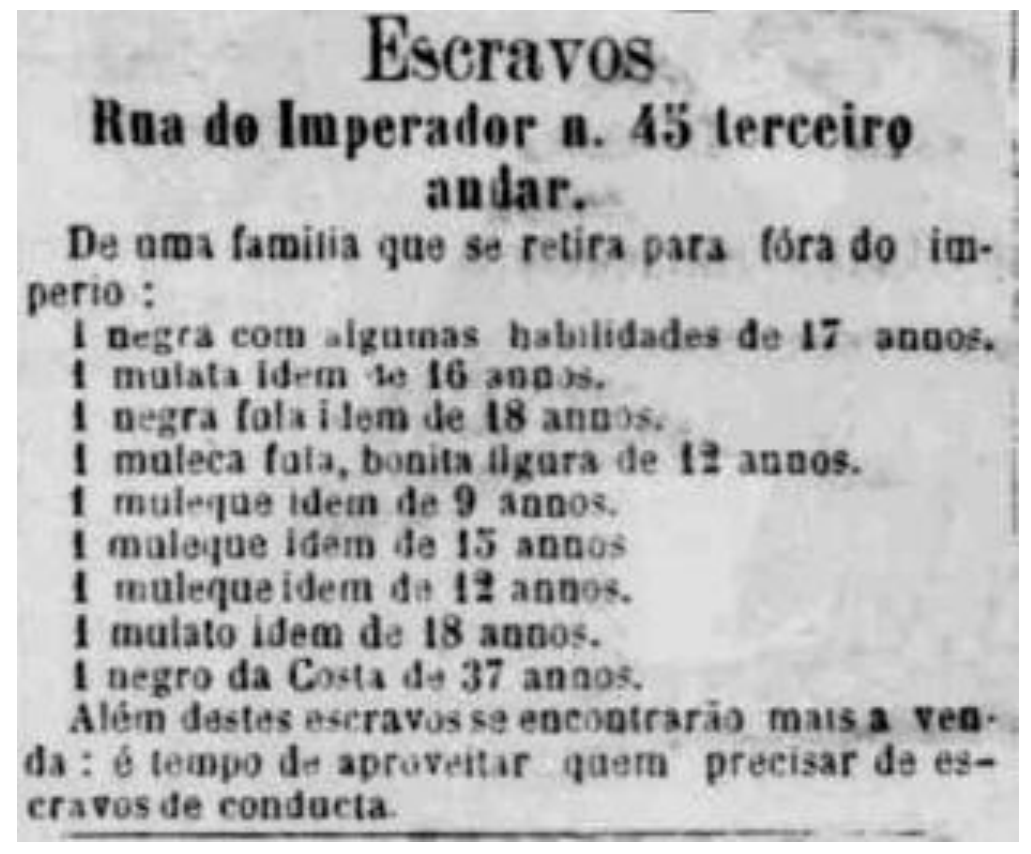

Fonte: LOPES, D. Revisitando anúncios de escravos do século 19.

Figura 11 - Anúncio publicado no Correio Paulistano, em 01 de novembro de 1863

\section{Coserava á venda.}

YEXDE-SE uma parda escrava, de 25 annos de itade, sabendo lavar, costurar o engomar perfeitameate, e con intelligencia de tailas os servięos de una casa de familia. As comprailor se dirà os motivos ta venda, nilo tendo a mesma escrava vieio algum.

$$
\text { Trata-se ua rua da Freira n.27. 2-8 }
$$

Fonte: LOPES, D. Revisitando anúncios de escravos do século 19.

Os anúncios abordam o período colonialista-escravocrata do Brasil em que os sujeitosnegros eram vendidos como mercadorias. O sujeitos-negros escravizados domésticos custavam mais caro, pois, como mostra os anúncios, tinham que ter "boas condutas", a da 
servidão e do trabalho forçado, inclusive, alguns desses sujeitos eram alugados, já que isso representava orgulho para as famílias colonialistas brancas ostentarem os sujeitos escravizados.

É possível também observar sujeitos-negros menores de idade sendo comercializados, fruto de um período nebuloso, violento e brutal que tinha o discurso racista no cerne da estrutura desigual de poder. No entanto, por essa estrutura social racista estar presente na contemporaneidade, ainda é possível encontrarmos crianças e adolescentes negras e negros em muitas esquinas e farois do país em busca da sobrevivência material.

Todo esse processo sócio-histórico-ideológico funcionam silenciando o protagonismo dos sujeitos-negros, assim como suas práticas históricas de resistência. E isso provoca a ausência de intelectuais negros nas ementas acadêmicas, por exemplo, como Abdias Nasciment, Clóvis Steiger de Assis Moura, Sueli Carneiro Jacoel, Lélia d'Almeida Gonzalez, Djamila Taís Ribeiro dos Santos, Joice Berth, Silvio Luiz de Ameida, Nilma Lino Gomes, Grada Kilomba, entre outras e outros, porque incomodam ao produzir ciência que desconstrói imagens discriminatórias, como as do dicionário, em relação aos sujeitos-negros.

Outra situação que contribui para pensarmos a questão do corpo negro, agora, na literatura, é a personagem Tia Nastácia, Sítio do Picau Amarelo, de Monteiro Lobato, vista como a negra de estimação que carregou Lúcia quando pequena. Tia Nastácia apesar de desfrutar da afetividade da matriarcal família branca, é na cozinha o seu lugar, emblema da sua desqualificação social.

Se no dicionário mulher negra é discursiviada como a que trabalha, provavelmente não está atrelado a serviços de hierarquias de chefia, e sim, a que exerce os trabalhos domésticos, inclusive Tia Nastácia é conhecida como a cozinheira que fazia comidas muito gostosas, no entanto, nas livrarias como Saraiva, Travessa, Cultura, o livro de receitas vendidos é a da D.Benta, em que a autoria e a escrita pertencem ao sujeito-branco, pois ao sujeito-negro cabe apenas as funções domésticas: limpar, cozinhar, cuidar, entre outros, assim como observadas nos anúncios publicitários.

Ao longo da obra lobatiana até mesmo a boneca de pano Emília desrepeita a velha, isto é, sente-se autorizada a falar com Tia Nastácia do modo que quiser, como sucede em algumas passagens de Histórias de Tia Nastácia: 
humorismo. Parecem-me muito grosseiras e até bárbaras - coisa mesmo de negra beiçuda, como Tia Nastácia. Não gosto, não gosto, e não gosto!

- Bem se vê que é preta e beiçuda! Não tem a menor filosofia, esta diaba. Sina é o seu nariz, sabe? Todos os viventes têm o mesmo direito à vida, e para mim matar um carneirinho é crime ainda maior do que matar um homem. Facínora!

- Emília , Emília! - ralhou Dona Benta.

A boneca botou-lhe a língua ( LOBATO, 1957, p. 132 ).

Como pode-se observar, Emília chama Tia Nastácia de "preta, beiçuda, diaba, burra, ignorante, grosseira, bárbara", sentidos que desunamizam Tia Nástacia e não contribuem para a quebra dos estereótipos sobre o negro. Por isso é importantíssimo projetos como a de Joyce Fernandas, historiadora e rapper conhecida como Preta-Rara, decidiu criar a página $E u$ Empregeda Doméstica que, ao ser lançada no Facebook, teve 40 mil curtidas em menos de 24 horas, em julho de 2016.

A página é permeada de relatos discursivos de mulheres que trabalham ou já trabalharam de empregada doméstica, em sua maioria negras. Nas postagens, poucas são as histórias felizes dessas mulheres, pois a grande parte dos relatos abordam a violenta estrutura desigual de poder, cujo racismo está presente, afinal, empregadas domésticas não precisam ter currículo, nome e, sim, qualidades braçais de força de trabalho, conforme visto nos anúncios.

Carolina Maria de Jesus também foi empregada doméstica, porém, resistente aos mandos dos patrões, preferia catar papel nas ruas do que se submeter a esse tipo de trabalho. Por outro lado, também há relatos da escritora que, em muitas casas onde trabalhou, em vez de aproveitar seus momentos de folga, preferia ficar na biblioteca dos patrões quando a liberavam, pois ler era o seu maior prazer e recompensa (FARIAS, 2017).

A questão da pele é marcada quando se trata de Carolina Maria de Jesus, pele-preta que não se apaga até mesmo quando a autora passa a ter uma situação econômica melhor. É possível observar fotografias em que Carolina está vestida conforme o esperado para uma escritora e também com os cabelos "disciplinados", ou seja, a questão estética-corporal do sujeito-negro é o tempo todo uma preocupação, pois para ser "aceito" é preciso aceitar seguir os padrões impostos de beleza.

Figura 1 - Carolina Maria de Jesus dando início ao curso de viagens ao exterior 


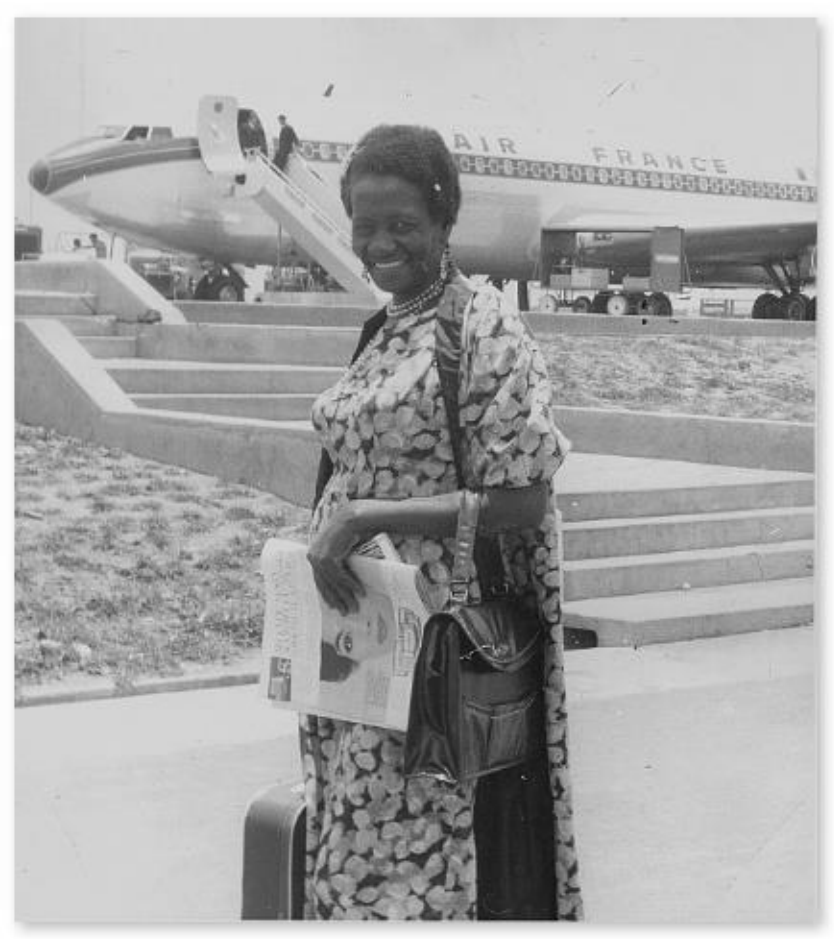

Fonte: FARIAS (2017)

Retomando a análise da crítica, é importante notar que o sujeito marca a palavra favela entre aspas, isto é, indicia dúvidas se a escritora viveu ou não na favela, ou, de um sujeito que, de tão afastado da realidade das favelas, não reconhece esse lugar em relação às suas misérias, reduzindo essa questão à ordem do poder público e das instituições religiosas, isto é, também nos indicia que há um discurso atrelado à região de sentidos da religião, como se por esse meio os miseráveis tivessem acesso à "assistência social", no sentindo mais rudimentar, a da doação, não ao próximo, mas daqueles que, pela hipocrisia, "salvam", ajudam os "necessitados" que merecem ser "consolados".

Por fim, o sujeito enfatiza a venda das obras e do poder publicitário em relação à "morfina escritora", novamente outro discurso entre aspas, modos de sinalizar a deslegitimação da autoria de Carolina e sua obra, evocando sentidos de uma escrita que alenta, reconforta, que é bálsamo, por isso vende.

O sucesso do sujeito-autor no plano econômico é fator fundamental em uma sociedade de disputas de poder, deste modo, se um autor não publica sua obra não consegue ganhar visibilidade, por outro lado, se o autor consegue a publicação e sucesso nas vendas passa a ser aviltado, exceto, se esse autor já tiver seu nome de autor legitimado na sociedade.

Na contemporaneidade, em que o conceito de literatura, por sua vez de clássico e cânone 
continuam em constante disputa e conceituação, muitas vezes, conjugado ao discurso autoritário que impede o polêmico, Carolina Maria de Jesus ao ser selecionada na lista de livros de dois vestibulares do país (UNICAMP E UFRGS) volta a ganhar um espaço no mercado editorial, principalmente, no dos livros didáticos, o que contribui para que a escola aborde autoras negras.

Todavia, a obra escolhida por essas instituições de Ensino é o Quarto de Despejo: diário de uma favelada (2014), isto é, ainda não se avançou na seleção de outras obras da escritora que possibilitam um olhar mais ampliado a respeito da sua literatura, mas, mesmo nessas condições de produção, já temos um modo de romper com o silenciamento da autoria de mulheres negras e suas literaturas na atualidade.

Orlandi (1996b, p. 69) desloca a noção de autor em Foucault (2001) - um quadro restrito e privilegiado de produtores "originais" de linguagem (em relação a uma obra) - e concebe que o "autor é aquele que responde pelo que diz ou escreve, pois é suposto estar em sua origem”, isto é, sempre que um sujeito se coloca como origem do dizer, ilusão necessária (PÊCHEUX, 2009), que se responsabiliza pelo que diz e produz um texto com unidade, coerência etc, esse sujeito está desempenhando a função-autor, portanto, para ser autor é preciso que o que ele produz seja interpretável, concepção de autoria que defendemos neste trabalho.

Para Pacífico (2002), que concorda com a concepção de autor apresentada anteriormente, a autoria está relacionada ao arquivo, em que abrir espaços para a interpretação significa possibilitar acesso ao arquivo. $\mathrm{O}$ arquivo entendido como "campo de documentos disponíveis e pertinentes sobre dada questão" (PÊCHEUX, 2009).

A autora nos aponta, também, que é preciso abrir espaços para que o sujeito se sinta autorizado a dizer, portanto, a posicionar-se como autor. A legitimação dos sentidos e do dizer na literatura, assim como a interdição desse dizer e dos sentidos - efeito da política literária está atrelada à autorização do dizer. E é essa defesa de autor que fazemos nesta dissertação, em que essa questão da autoria será discutida melhor nos próximos capítulos, de antemão, podemos dizer que ainda há um silenciamento ao dizer, tanto pela escola, quanto em relação a certas autoras e autores e suas obras, desembocando em um cerceamento do sujeito-autor.

Defendemos que Carolina Maria de Jesus rompe com um conceito fechado de literatura que considera o "escrever difícil" como legitimação de um "clássico literário", afinal, a obra do escritor Saint-Exupéry, O pequeno príncipe (1997), é, em alguns discursos e espaços, 
reconhecido (lido, interpretado) como um "clássico da literatura" e nem por isso apresenta uma escrita de "grandes" desafios estilísticos ou vocabulários de uma certa língua "eruditizada" (neologismo que muito nos serve para essa discussão).

O mercado editorial que tende a visar exclusivamente ao lucro, salvo exceções, joga esse jogo e ora defende a literatura com "L", ora a literatura com "l”, contribuindo para que essa disputa literária da legitimação fique ainda mais repleta de rachaduras, furos, pelo efeito da opacidade da linguagem, visto que nunca se conseguirá "fechar" os sentidos de uma discussão que se pretende sempre atualizável, aberta e em disputa.

É por isso que compreendemos que a literatura produzida por Carolina Maria de Jesus joga o jogo da política literária pendulando o tempo todo de um lado a outro, isto é, sua autoria é legitimada e interditada ao mesmo tempo.

Se por um lado consideramos as obras produzidas por esse sujeito na categoria da literatura, por outro, ainda há diversos espaços que não reconhecem os escritos de Carolina como literatura. Nessa direção, se ao ser tratada a escrita de Carolina na categoria de literatura, ela ainda, a nosso ver, não conquistou o espaço nas obras "imortais" da literatura brasileira, fruto de uma formação imaginária, sustentada em uma formação discursiva que silencia a voz de sujeitos-autores negros. Por fim, se o mercado editorial garantiu a publicação e publicidade de algumas obras dessa autora, por outro, também nunca se preocupou em reconhecê-la como literatura de qualidade, pois não cabe juízos de valor, mas sim, o lucro.

Depois de toda essa discussão sobre o funcionamento da política literária na voz do mercado editorial e da crítica, no próximo capítulo apresentaremos o método e a metodologia deste trabalho, abordando o referencial teórico, o processo de desenvolvimento desta pesquisa e o modo como concebemos a autoria de mulheres negras na literatura a partir do viés da resistência, neste caso, trabalhando essas vias da renitência. 


\section{O TERRITÓRIO MOVENTE DAS PALAVRAS NA ANÁLISE DE DISCURSO: DISPOSITIVOS E PROCEDIMENTOS ANALÍTICOS}

Figura 13 - (In)conclusões - Babel, escultura em argila

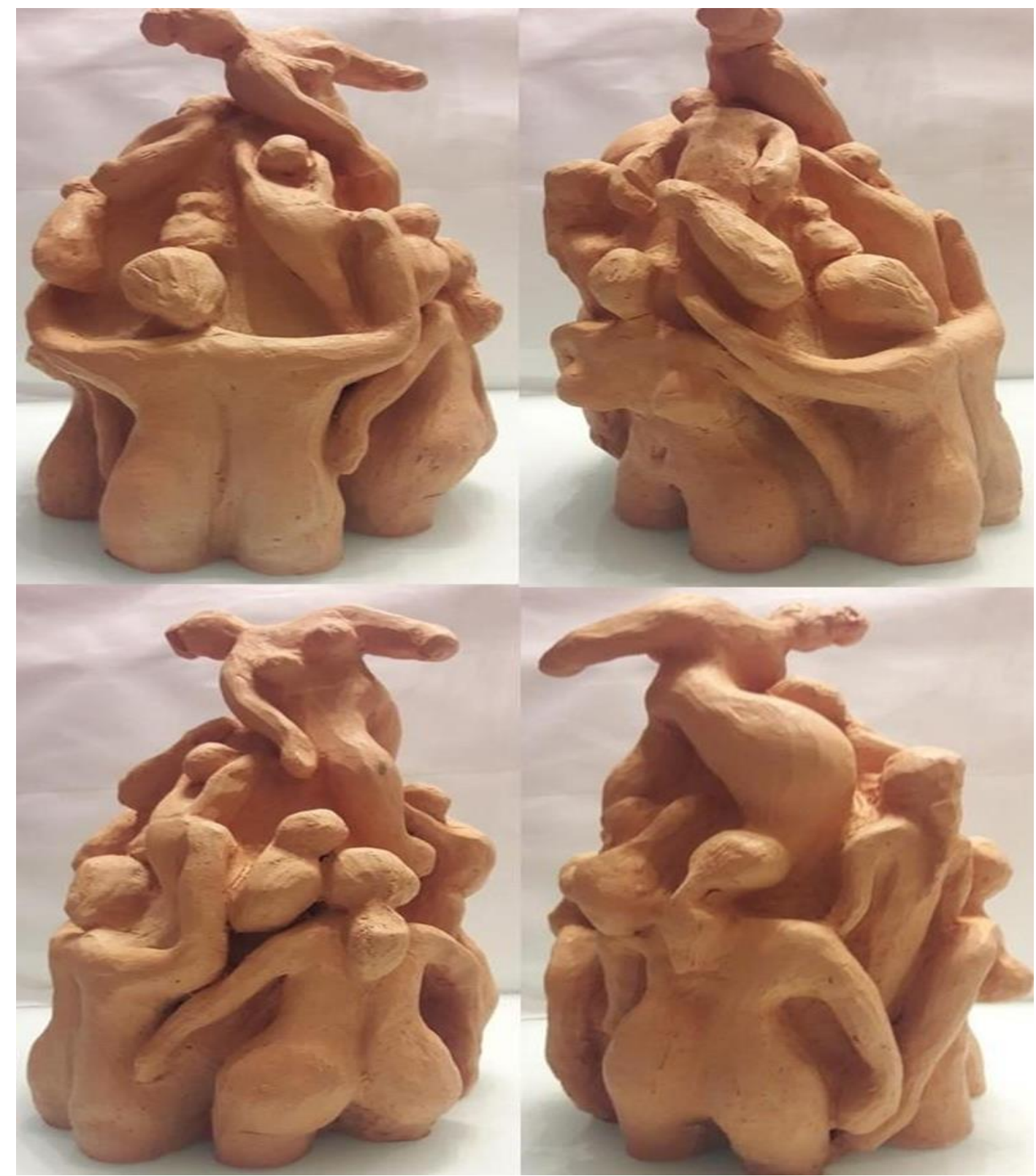

Fonte: Lucília Abrahão (2018)

Observava a aranha em suas peripécias acrobáticas. Pendia do teto num estranho equilibrismo. O fio que sustentava era tênue, invisivel. Os olhos hipnotizados acompanhavam o sobe e desce do inseto. Às vezes, a pequena aranha, como a provocá-la, descia próximo a sua cabeça e, com movimentos rápidos e graciosos, retornava, aproximando-se do teto. Poderia ficar ali por horas, dias, meses a fio. Ela e a aranha tecendo fios infinitos, brincando com a gravidade. Cecília tecendo fios invisiveis, a aranha fabricando fios reais. (Miriam Alves, Cadernos negros 24, p. 89-93). 
O postulado teórico em que esta pesquisa se ancora são os da Análise de Discurso de "linha" francesa (AD), cujo maior expoente foi o Michel Pêcheux (1938-1983), fundador da Escola Francesa de Análise do Discurso. Essa teoria teve sua origem na década de 60, no século XX, em que diversos estudiosos da leitura e da interpretação se preocupavam em compreender o que a atividade de leitura significava. É questionada a partir desses estudos a afirmação positivista de linguagem de que basta conhecer uma língua e estar alfabetizado para saber ler, interpretar e compreender as mensagens, as informações escritas, ou seja, o importante é ter acesso e dominar o "código" linguístico.

A partir da teoria da Análise do Discurso, ler e escrever são processos que envolvem muito mais que a mera codificação e decodificação da língua escrita, já que os sentidos produzidos nos textos estão marcados pela sua historicidade na memória enunciativodiscursiva e de fatores ideológicos em relação à constituição dos processos de significação. Podemos dizer que:

[...] a Análise do Discurso trabalha com a materialidade da linguagem, considerando-a em seu duplo aspecto: o linguístico e o histórico, enquanto indissociáveis no processo de produção do sujeito do discurso e dos sentidos que (o) significam. $O$ que permite dizer que o sujeito é um lugar de significação historicamente constituído (ORLANDI, 2007, p. 37).

Neste contexto, a Análise de Discurso compor-se-á de três esferas do conhecimento: o marxismo - materialidade e opacidade histórica - como teoria das formações sociais e suas transformações; a linguística - materialidade e opacidade da linguagem - como a teoria dos mecanismos sintáticos e dos processos de significação; e a psicanálise - materialidade e opacidade do sujeito - tendo, assim, a teoria do discurso, como a teoria da determinação histórica dos processos de significação (ORLANDI, 2001, p. 15).

A teoria do discurso preocupa-se em compreender como se instituem os efeitos de sentido no discurso no encontro entre a língua e o efeito-sujeito (formações imaginárias que designam as posições ocupadas pelos sujeitos) e a história.

O discurso é aquilo que está situado entre a língua e a ideologia, é o efeito de sentidos entre os interlocutores, o lugar de interação e confronto entre o linguístico e o ideológico, tendo como base material a língua.

É a ideia de movimento que atrai as questões do discurso, em que Orlandi (2012) amparada em Pêcheux (1969) vai dizer que é preciso deslocar a noção de "função" para a de 
"funcionamento", pois não se descreve a função, mas sim, o funcionamento da linguagem, portanto, todo discurso se produz em certas condições e esse processo tem de ser considerado para compreender a construção dos sentidos.

A teoria da Análise de Discurso não está preocupada em buscar o verdadeiro sentido dos discursos como aponta Orlandi (2001), não é um conceito fechado, pronto e acabado, mas trabalha com a consideração de que o sentido sempre pode vir a ser outro e que isso dependerá da relação dos interlocutores e deles com o objeto discursivo. O sentido é compreendido como um efeito de sentido entre sujeitos em interlocução.

Assim, o objeto de estudo da Análise de Discurso é o Discurso, ou seja, é o de procurar perceber o movimento social da história na língua e o modo como os sujeitos e os sentidos são afetados por esse movimento, o que implica refletir sobre o modo como os sujeitos se identificam com certos sentidos e não outros, conforme aponta Orlandi (2001) que:

\begin{abstract}
A Análise do Discurso se propõe construir escutas que permitam levar em conta esses efeitos e explicitar a relação com esse 'saber' que não se aprende, não se ensina, mas que produz seus efeitos. Essa nova prática de leitura, que é a discursiva, consiste em considerar o que é dito em um discurso e o que é dito em outro, o que é dito de um modo o que é dito de outro, procurando escutar o não-dito naquilo que é dito, como uma presença de uma ausência necessária. Isso porque só uma parte do dizível é acessível ao sujeito, pois mesmo o que ele não diz (e que muitas vezes ele desconhece) significa em suas palavras. (ORLANDI, 2001, p. 34).
\end{abstract}

Para a $\mathrm{AD}$, a noção de sujeito diverge/afasta-se da de indivíduo empírico, já que não é transparente nem para si mesmo e nem para os outros, ele é "assujeitado" pelas ideologias e em seus discursos, pois o sujeito apropria-se socialmente da linguagem sendo interpelado pela ideologia. Isso significa que o sujeito pode ocupar várias posições-sujeito (lugares sociais: professor, aluno, pai, patrão, funcionário, etc) e a partir delas que irá produzir seu discurso. Ele não é o centro do seu dizer, pois é constituído de uma heterogeneidade de discursos.

É a ideologia que fornece as evidências pelas quais "todo mundo sabe" o que é um soldado, um operário, um patrão, uma fábrica, uma greve, etc., evidências que fazem com que uma palavra ou um enunciado "queira dizer o que realmente dizem" e que mascaram, assim, sob a "transparência da linguagem", aquilo que chamaremos o caráter material do sentido das palavras e dos enunciados. (PECHÊUX, 2009, p. 144).

O sujeito é um efeito ideológico elementar, portanto, deste modo, "o sujeito do discurso ocupa um lugar de onde enuncia, e é este lugar entendido como a representação de traços de 
determinado lugar social que determina o que ele pode ou não dizer a partir dali” (MUSSALIM, 2004, p. 133).

Levando em conta as considerações sobre o modo como o sujeito é concebido na AD, quando discutimos as obras de Carolina Maria de Jesus é por meio de uma posição discursiva, a saber, a de sujeito-autor.

A partir dessa posição de sujeito-autor, esta pesquisa teve o objetivo de investigar o modo como esse sujeito, pela escrita, constitui-se como autor de literatura. Nesse sentido, buscamos ainda investigar, nas marcas de autoria desse sujeito, os efeitos de sentido de resistência que fazem com que a sua produção literária possa ser designada como literatura de enfrentamento social, que joga o jogo da política literária, contribuindo, por fim, para refletirmos sobre e questionarmos a ausência de autoras negras na escola e em outras instituições.

A partir dos postulados analíticos, metodológicos e teóricos da $\mathrm{AD}$, o corpus desse trabalho será composto por duas obras Quarto de Despejo: diário de uma favelada (2014) e Diário de Bitita (2016).

Ainda tratando da concepção de sujeito para $\mathrm{AD}$, é por esse motivo que também marcamos a posição sujeito-professor e a posição sujeito-aluno quando tratamos das relações estabelecidas na escola, visto que é nessa relação que ocorre o trabalho com a literatura em sala de aula, consequentemente, é a partir dessas posições que esses sujeitos sustentam os seus discursos sobre a literatura, por meio de representações imaginárias, portanto, inconscientes e ideológicas, sendo que estas fazem parecer natural o sujeito produzir o seu discurso de uma forma e não de outra.

A questão da posição-sujeito nos leva a abordar o conceito sobre formação imaginária (FI) e formação discursiva (FD), posto que "o que funciona nos processos discursivos é uma série de formações imaginárias que designam o lugar que A e B se atribuem cada um a si e ao outro, a imagem que eles fazem de seu próprio lugar e do lugar do outro" (PÊCHEUX, 2014, p. 82).

Todo processo discursivo supõe a existência das formações imaginárias, isto é, "quem sou eu para the falar assim?", “quem é ele para que eu lhe fale assim?”, "quem sou eu para que ele me fale assim?", “quem é ele para que me fale assim?” (PÊCHEUX, 2014, p. 83). Esse jogo interfere nas condições de produção do discurso, que para Pêcheux constituem a ligação entre as "circunstâncias de um discurso" e o seu processo de produção.

Nesse sentido, entendemos que Carolina Maria de Jesus, mulher, mãe, negra, pobre, 
favelada, a partir da sua autorização ao dizer (que a nosso ver é resistência), isto é, a ocupar a posição de sujeito-autor, provoca o incômodo, "abre feridas", surpreende, (re)mexe as questões da política literária, visto que há uma formação imaginária sobre o que é ser autor que deslegitima a escrita de um sujeito inserido em condições de produção como as citadas.

Figura 2 - Carolina autografando seu livro durante o I Festival do Rio, em 09 de novembro de 1960

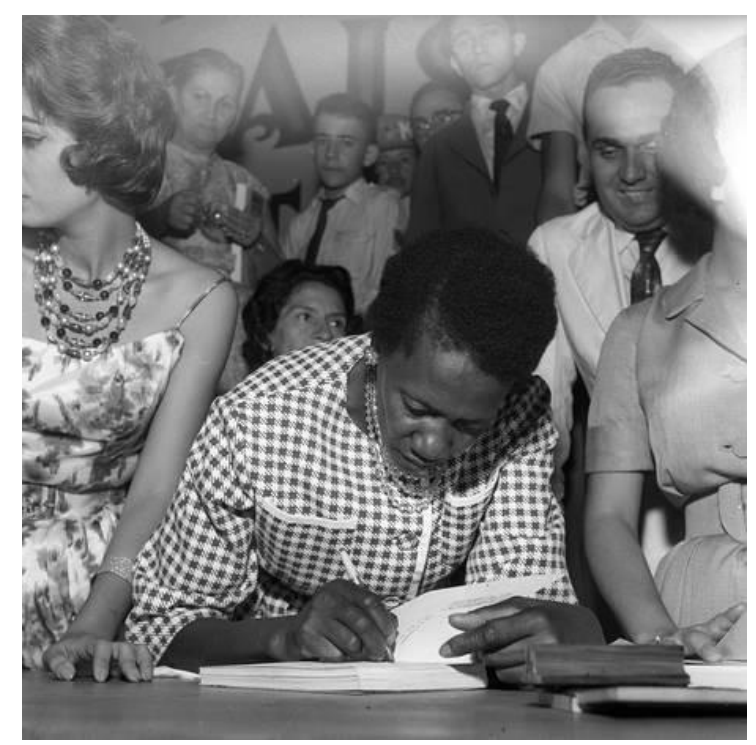

Fonte: FARIAS (2017)

Como a teoria discursiva defende, o que está em jogo são as formações imaginárias mecanismo de funcionamento discursivo - que provoca um jogo de imagens dos sujeitos entre si, dos sujeitos com os lugares que ocupam na formação social e dos discursos já ditos com os possíveis e imaginados, isto é, para a $\mathrm{AD}$ não dizem respeito a sujeitos e lugares empíricos, mas às imagens resultantes dessas projeções.

É por isso que defendemos que a posição de sujeito-autor de Carolina Maria de Jesus é um ato político, já que não é possível deixar de relacionar a escrita de Carolina como resistência do dizer, decorrente de um meio social que silencia a voz do negro, ainda mais, se for mulher, mãe, negra, periférica. Antecipamos um recorte como argumento em defesa do que estamos defendendo e já abrindo caminho para as análises, que serão apresentadas no capítulo seguinte.

Recorte 1: O que eu notava é que nas festas dos negros os brancos não iam. Um dia apareceu um senhor que não tinha as pernas. Distribuiu uns convites convidando o povo para ir ouvi-lo tocar violão no cine Recreio. Tocou a valsa "Saudades do 
Matão”. A valsa já era por demais conhecida. Não foi um sucesso. Creio que estava aprendendo, porque não sabia ajustar a melodia tocando e a música cantando. Ou era mentiroso.

Vaiaram o pobre homem!

- Fora! Vai tocar lá na China!

Que gargalhada. Todos sorriram, menos eu.

Porque a tristeza que notei no rosto do artista revelava que deveria existir qualquer coisa funesta na sua vida. Seria o complexo por não ter as pernas?

(JESUS, 2016, p.27).

Neste recorte, temos um sujeito que "nota" uma questão racial de "apartheid" ao perceber que nas festas dos negros, os brancos não participavam, depois, por meio de uma formação imaginária sobre o lugar de negros e brancos, na sociedade brasileira, procura justificar o motivo de o artista não ter conseguido tocar a valsa, "creio que estava aprendendo", "ou era mentiroso".

Enquanto todos "gargalhavam", "vaiam o pobre homem" solicitando que fosse tocar na China (por que a China?). Talvez por ter uma representação de um país distante, de uma língua "diferente", de outro povo que não reclamaria daquela cantoria, o sujeito reconhece algo "funesto" no rosto do artista, e sem saber como interpretar, atrela ao fato de ele não ter as pernas, "seria complexo?". Portanto, temos um sujeito que não se filia à ideologia da maioria do público, visto que entre "gargalhar" ou não das condições artísticas do outro, prefere buscar os sentidos da cantoria ruim apresentada.

"Esse complexo por não ter as pernas", leva-nos a pensar nas obras de Carolina Maria de Jesus, que levou muito tempo para ser descoberta e publicada. Haveria algo na literatura de Carolina que incomodaria tanto para que não fosse reconhecida? Quais "pernas" ainda "faltam(vam)" para que suas obras pudessem ou possam ser mais visualizadas e viabilizadas? A nosso ver, assim como fizeram com o "artista sem pernas", as "gargalhadas", ainda há um discurso que deslegitima a autoria dos que não estão autorizados a dizer: o pobre, o negro, a mulher, o homossexual, as travestis etc, isto é, todos que estão à margem, nas bordas, o que indica que "tomar a palavra" é uma questão de transgressão discursiva, sobretudo, porque é uma questão de poder, não "apenas" de arte, de cantoria, de literatura, mas sim, de quem está praticando tal ato.

Ao escolhermos para este trabalho o nome de Carolina Maria de Jesus foi na tentativa de mostrarmos a força que a "tomada da palavra" pode ter na vida de um sujeito, como na dessa autora, que passa a significar-se no mundo por meio da sua posição de autor, por isso, a importância do acesso à leitura e à escrita em uma sociedade em que a língua é poder, como 
nos apresenta Gnerre (2009, p. 05) ao dizer que "as pessoas falam para serem "ouvidas", às vezes, para serem respeitadas e também para exercer uma influência no ambiente em que realizam os atos linguísticos".

Esperamos contribuir com esta dissertação para que os arquivos sobre a literatura de autoria de mulheres negras, neste caso, das obras de Carolina Maria de Jesus, sejam mais visualizados e viabilizados nas escolas e centros acadêmicos, na garantia e defesa das literaturas.

\subsection{Sobre a constituição do corpus}

O corpus que nos propomos analisar nesta dissertação teve sua origem durante uma aula sobre poesia, numa sala de quarto ano do Ensino Fundamental, de uma escola particular de Ribeirão Preto, quando deparei-me com um sujeito-aluno, negro, que nos questionou se, na posição de sujeito-professor conhecíamos alguma autora de poesia negra. Na verdade, não conhecíamos e nem tínhamos tido acesso a nenhuma autora negra, seja de literatura ou não.

Alguns meses depois, o Serviço Social da Indústria (SESC) de Ribeirão Preto promoveu uma minicurso intitulado: A Literatura Feminina Negra, dado pela professora de língua portuguesa e poetisa Carmem Faustino, e pela jornalista e poetisa Elizandra Souza, do qual pudemos participar, suscitando ainda mais o nosso interesse pela literatura de autoria de mulheres negras. Neste minicurso, pudemos conhecer diversas autoras, o que nos causou um susto, pois, além de ser um arquivo desconhecido por nós, que estávamos filiados, até então, à formação discursiva de que essas mulheres não existiam no campo literário. Por isso, consideramos que esse minicurso foi a "sementinha" desta pesquisa.

Incomodados com essa situação da ausência de mulheres negras na escola, começamos, também, a refletir sobre o meio acadêmico que, similarmente, à escola desconhecia e/ou negava essas autoras, de modo que nas duas graduações que cursei, nenhuma delas possibilitou-nos o contato com essa literatura.

Diante disso, após termos realizado o trabalho de conclusão de curso, intitulado, $O$ “corpo-estranho" da poesia e a produção de sentidos na escola (2016), orientado pela professora doutora Soraya Maria Romano Pacífico, decidimos prestar o processo seletivo do programa de pós-graduação em Educação, pela universidade onde essa pesquisa se deu, no intuito de que nossa orientadora do TCC pudesse entrar nessa empreitada conosco, 
questionando, justamente, esse silenciamento da autoria literária de mulheres negras.

A partir disso, depois de ter conseguido ingressar no programa de pós-graduação, no primeiro momento, em comum acordo orientadora e orientando, pensamos em trabalhar com diversas autoras negras de poesia, de modo que pudéssemos dar continuidade ao trabalho de conclusão de curso, cujo tema era poesia.

Ao começarmos o processo de seleção das obras e das autoras, consequentemente, deparamos com Carolina Maria de Jesus e as algumas de suas obras, dentre elas, a do corpus desta dissertação. Naquele instante, depois da leitura das obras e uma pesquisa intensa sobre a vida da autora, observarmos que estava ali o que gostaríamos de focar neste trabalho: a questão da política literária e o seu funcionamento, visto que o nosso desejo era refletir e questionar a ausência de mulheres negras nas feiras literárias, livrarias, ementas acadêmicas e, evidentemente, no currículo da escola.

Foi daí que começamos a engendrar um trabalho sobre a relação de poder desigual que essa política literária provoca na interdição de certas autoras e autores, no caso, em especial, as autoras negras; e a legitimação de outros, em que passamos a observar que isso se dava devido ao conceito (polissêmico) do que é literatura, por sua vez, uma obra clássica, assim como o funcionamento do mercado editorial que também é um contribuinte significativo nesse processo de funcionamento do político na literatura.

Para tratar da questão sobre os conceitos de literatura, por sua vez, de clássico, assim como o funcionamento do discurso do mercado editorial, trabalhamos com diversos autores da análise de discurso e teoria e crítica literária, a fim de observarmos o jogo discursivo político do campo minado da literatura.

Feito isso, deparamos com a interdição da autoria de mulheres negras e, focados em Carolina Maria de Jesus, passamos a compreender que a questão do racismo estrutural era substancial para a discussão sobre o modo como a política literária interferia na autoria de mulheres negras. Deste modo, debruçamo-nos a observar o funcionamento discursivo dessa estrutura desigual de poder e como ela "alimentava" o descrédito da literatura dita como das margens e estudamos diversos autores que discutem essa questão, muitos deles, na chamada teoria pós-colonialista, crítica e feminista.

Por fim, chegamos ao corpus desta dissertação, porque acreditamos que toda discussão que fizemos sobre o funcionamento da política literária era possível de ser observada na literatura de Carolina Maria de Jesus, que sofria os processos da legitimação e da interdição 
ao mesmo tempo.

Conforme procuramos abordar, neste capítulo, o analista de discurso é aquele que se aprofunda na opacidade do texto e que busca compreender como ele é produzido e quais os seus sentidos, observando como somos afetados pela língua e pela história. Diante disso, reconhecendo a autoria de Carolina Maria de Jesus, na posição de sujeito-autor, utilizamos o corpus deste trabalho selecionando recortes que indiciassem o nosso argumento de que tratase de uma literatura de enfrentamento social que se dá pela via da autoria e da resistência.

A ideia de recorte, segundo Orlandi (2001) dever ser compreendida como "uma unidade discursiva", como um "fragmento correlacionado de linguagem - e situação", de modo que "o texto é o todo que organiza os recortes", tendo, pois, "compromisso com as tais condições de produção, com a situação discursiva". Além disso, a noção de recorte se remete à polissemia e não deve ser visto apenas como um amontoado de informações, Pacífico (2002, p. 64) diz que os recortes "não devem ser compreendidos enquanto estrutura linear, mas sim, como pedaços, "nacos" do discurso, onde estarão materializados linguisticamente os indícios de um modo de funcionamento".

Para isso, em relação à obra Quarto de Despejo: diário de uma favelada (2014), procuramos atentamente selecionar recortes que pudessem trazer marcas linguísticas da relação do sujeito-autor com a escrita, de modo que pudessémos analisar o processo de autoria desse autor pela via da resistência desembocada pelo poético, pois acreditamos que é justamente por esse caminho que a literatura desse autor pode ser defendida como literatura de enfrentamento social.

Depois, selecionamos os recortes da obra, Diário de Bitita (2016), levando em consideração dois grandes blocos de movimentos discursivos de análise: um sobre a escola e o outro sobre aquilo que designamos de escrita-inagadora produtora de uma literaturafilosófica.

No primeiro movimento discursivo, selecionamos os recortes do capítulo, A escola, de modo que pudéssemos analisar os efeitos de sentidos desencadeados pela autoria desse sujeito-autor, a fim de observarmos como a escola foi discursivizada nessa obra. Esse trabalho já constitui um gesto analítico e nos proporcionou engendrar uma discussão sobre o papel da escola na promoção da literatura de autoria de mulheres negras, tema essencial do nosso trabalho.

No segundo movimento discursivo, selecionamos recortes a partir de diversos capítulos 
da obra, que mostrassem o modo como esse sujeito-autor resiste na não autorização do dizer pelo outro, conforme as formações imaginárias do que seja um sujeito-negro, um sujeitoautor, enfim, produzindo o que designamos por uma literatura-filosófica, porque por meio de uma escrita-indagadora, o sujeito-autor materializou um texto repleto de questionamentos existenciais, em que essas perguntas "desestabilizam o semanticamente estabilizado" (PÊCHEUX, 2009).

Deste modo, no próximo capítulo trataremos das análises que fizemos dos recortes do corpus desta dissertação. A ideia de recorte, conforme já apontamos, relaciona-se, fundamentalmente, com o conceito de marcas discursivas que falamos, visto que serão tais marcas, tais vestígios do sujeito em seu dizer que pretendemos apresentar ao leitor em nossas análises, na defesa de que a literatura de Carolina Maria de Jesus se dá no enfrentamento social, pela via da autoria e da resistência. 


\section{AUTORIA E RESISTÊNCIA EM CAROLINA MARIA DE JESUS}

E agora quando a vejo remexendo no lixo - procurando o quê? Aquilo que assassinamos? Digo que não plantei as sementes fundo demais, a culpa foi do solo, da terra, da nossa cidade. Agora até penso que a terra do país inteiro era hostil a cravos-de-defuntos naquele ano. Este solo é ruim para certos tipos de flores. Não nutre certas sementes, não dá certos tipos de frutos, e quando a terra mata voluntariamente, aquiescemos e dizemos que a vítima não tinha direito de nascer (MORRISON, 1970, p. 205 - 207).

Figura 15 - Vento frio, dentro. Vento frio, fora. Vento, frio dentro e fora. Vento frio lá fora, acrílico sobre tela

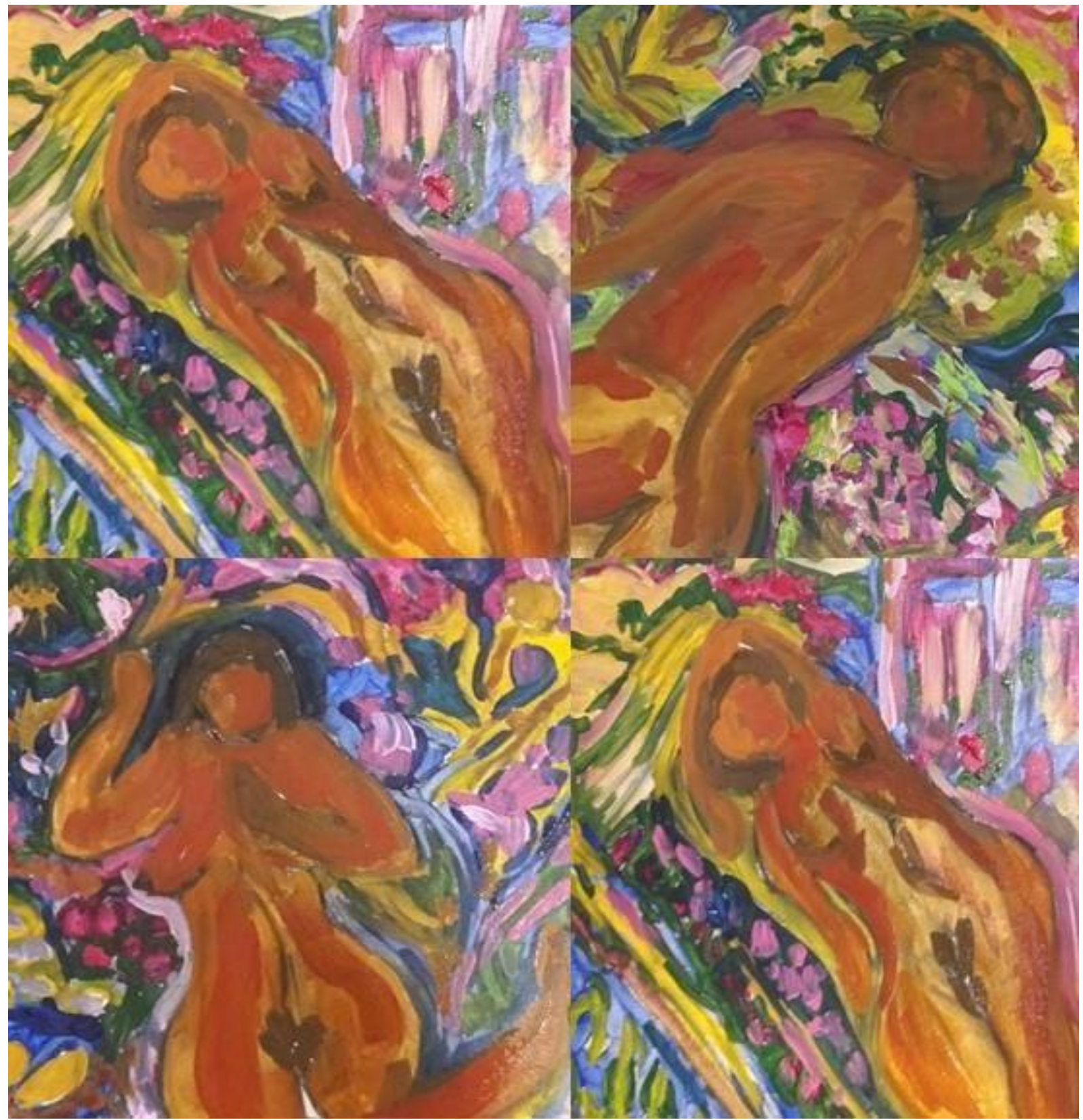

Fonte: Lucília Abrahão (2018) 
Conforme temos argumentado nos capítulos anteriores, Carolina Maria de Jesus sofreu a interdição da política literária que se apoia na formação imaginária a respeito do que seja um autor ideal, autorizado, por parte dos críticos. Por outro lado, sua obra Quarto de Despejo: diário de uma favelada (2014), quando foi lançada em 1960, teve um grande sucesso editorial, sendo, inclusive, traduzido para outros países, o que constitui em um modo de legitimação, assim como a entrada na lista de renomados vestibulares do país (UNICAMP E UFRGS) na atualidade. É nesse pêndulo entre a legitimação e a interdição da política literária que a literatura de Carolina Maria de Jesus se movimentou e, podemos dizer, continua a movimentar-se.

Carolina Maria de Jesus, residente da favela de Canindé, São Paulo, escrevia com os restos de papel que encontrava na sua saga como catadora de papelão. Em um cenário decadente, a autora fazia as suas leituras e escrevia nos intervalos entre os afazeres rotineiros e as intervenções dos vizinhos e de seus filhos, conforme mostraremos nas análises dos recortes. É por isso que consideramos a literatura produzida por Carolina como resistência, visto que, em meio a um ambiente inóspito, em que a leitura e a escrita nem sempre fazem parte, Carolina, na posição de sujeito-autor, autorizava-se a dizer.

Carolina Maria de Jesus é literatura porque, a partir da posição de sujeito-autor, sua "fome" da escrita e também de acesso aos alimentos, leva-nos a considerar seus livros como obras literárias humanizadoras (CANDIDO, 1988), especialmente, pelo fato de não silenciar certas misérias da humanidade.

As obras de Carolina Maria de Jesus, ao serem trabalhadas na escola, provoca uma (re)elaboração nos estudos literários, em que a voz improvável das margens disputa um lugar no currículo, fazendo com que os sujeitos-alunos acessem e construam arquivo (PÊCHEUX, 2009) sobre a literatura de autoria de mulheres negras, autorizando, inclusive, a existência das literaturas (plurais) na escola, pois só assim a ideia cristalizada e canonizada do discurso sobre as obras ditas clássicas poderão ruir a "fixidez" que impede a democracia do acesso às literaturas.

Se o discurso do mercado editorial capitalista legitima um autor e sua obra dando "acesso" e visibilidade a esses autores e autoras, isso sempre está atrelado ao lucro. Deste modo, importa a obra literária que vende e que chama atenção do público consumidor. Caso o autor e/ou sua obra não consigam gerar lucro para esse mercado, em pouco tempo serão negados e silenciados. 
Na contemporaneidade, as obras que, muitas vezes, geram lucros estão associadas à "literatura light" (LLOSA, 2003), pois importa a literatura que está em "moda", a do entretenimento, nesse sentido, o jogo do mercado editorial e da publicidade tendem a se preocuparem mais com a venda, do que com aquilo que se comercializa. Esse processo sustenta-se no discurso da democratização da cultura, porque não é um mercado que propaga unicamente os clássicos da literatura, mas as literaturas.

Isso é observável nas vitrines das grandes livrarias do país em que a literatura designada de "autoajuda" aflora nas estantes e topo das vendas. O problema não são as obras da "literatura light", mas sim, o modo como o mercado editorial opera, pois acaba por veicular determinados nomes e títulos, deixando de lado outros.

É só pensarmos nas obras de literatura de autoria de mulheres negras que, ainda hoje, são muito difíceis de serem encontradas nestas grandes livrarias, sustentadas por um discurso editorial (conforme já apontamos) que finge desconhecer essas mulheres e suas obras, negando-as, por não acreditar na capacidade de elas gerarem lucros.

No entanto, o que temos presenciado é que quando as livrarias mais populares do país decidem vender as obras de mulheres negras, muitas esgotam rapidamente, como é o caso da obra Poemas da recordação e outros movimentos (2018), da escritora Conceição Evaristo, que ficou por muitos anos esgotada nas prateleiras dessas lojas, tendo em 2018 uma nova edição. Outro exemplo são as obras de Carolina Maria de Jesus que também continuam sendo difíceis de serem encontradas nessas mesmas livrarias.

Diante dos vários caminhos e direções de sentidos que o corpus desta dissertação poderia seguir, escolhemos trabalhar a questão da autoria e da resistência em Carolina Maria de Jesus, por compreendermos que é o caminho oportuno para observarmos a política literária em funcionamento, pois defendemos que a literatura desse sujeito-autor está ancorada no enfrentamento social, em que selecionamos dois pontos fundamentais: a resistência pelo poético e a resistência frente a instituição escola, observando se esse lugar promove (ou não) a emancipação dos sujeitos-educandos, por meio de uma prática comprometida com o antirracismo.

Como analistas de discurso buscamos aprofundar-nos na opacidade do texto e compreender como ele é produzido e quais os seus sentidos, sabendo que também somos afetados pela língua, pela história e pela ideologia, procurando: 
estabelecendo a relação entre esses funcionamentos e formações discursivas que, por sua vez, remetem a uma certa formação ideológica. (ORLANDI, 2012, p. 34-35).

Por isso, é fundamental a ideia de recorte nas análises que se seguem; para isso, nossos gestos de interpretação se dão a partir do corpus já citado e referentes a esses dois pontos essenciais de movimentos discursivos de resistência, que nomeamos $A$ "fome da escrita" e a "escrita da fome": o poético na/da favela e As formas de enfrentamento social e superação pela assunção da autoria, os quais sustentarão nossa defesa da literatura de Carolina Maria de Jesus nesse campo do enfrentamento social.

\subsection{A "fome da escrita" e a "escrita da fome": o poético na/da favela}

(...) Quando eu passava na Avenida Tiradentes, uns operários que saiam da fábrica disse-me: - Carolina, já que você gosta de escrever, instiga o povo para adotar outro regime. Um operário perguntou-me: - É verdade que você come o que encontra do lixo? - O custo da vida nos obriga a não ter nojo de nada. Temos que imitar os animaes. (JESUS, 2014, p. 112).

Ao tratarmos sobre a escrita, inevitavelmente para nós, esse assunto nos leva a discutir sobre autoria. Isso porque a incompletude da linguagem é algo que faz parte do processo da escrita, em que tudo pode vir a ser, isto é, a "ilusão" de que tudo pode ser dito. Diante disso, o sujeito- autor tem uma tarefa complexa, metaforicamente, um "custo da vida", ao ter que tentar controlar o(s) sentido(s), ou seja, de colocar no papel algo que julga relevante em um determinado momento, principalmente, quando pensamos na responsabilidade pelo dizer e no “poder” que o sujeito-autor tem de materializar e perpetuar suas ideias, pela escrita.

Para Orlandi (1996b), a dispersão de um texto é controlada por meio do princípio de autoria, pois é quando o sujeito-autor procura controlar o sentido do texto, os pontos de fuga, a incoerência, que são possíveis linguisticamente.

É importante que o sujeito-autor consiga posicionar-se ao mesmo tempo como autor e leitor do seu texto, considerando, além dele próprio (autor), o outro (leitor) possível para seu texto, já que "o autor de um determinado texto é capturado por uma formação ideológica que se materializa em uma formação discursiva" (PACÍFICO, 2012, p. 81), que nem sempre é a mesma dos sujeitos-leitores que terão acesso a tal texto, haja vista que os sentidos interpretados pelos sujeitos-leitores podem ser outros, pois as palavras podem mudar de sentidos de acordo com as formações ideológicas em jogo.

Diante disso, para ser autor é preciso fazer uma "repetição histórica e não uma repetição 
formal" (PACÍFICO, 2012, p. 82). Para Orlandi (2012), a repetição pode ser: repetição empírica, não se historiciza; repetição formal, repetição mecânica de frases e conteúdos, portanto, também não se historiciza; e, por fim, a repetição histórica, que inscreve o repetível (interdiscurso, o já-lá) a história, na língua.

Podemos observar que as posições autor/leitor não se reduzem à dimensão da língua, isso porque elas englobam a dimensão histórica, o interdiscurso e a ideologia. Autor/leitor estão no movimento da linguagem e de sua incompletude, em que a significação é sempre construída junto com o texto, sabendo "que "as bordas" da significação transbordam e se mesclam com outras regiões de sentido" (PACÍFICO, 2012, p. 84).

Conforme Orlandi (1996b, p. 75) o lugar do autor é determinado pelo lugar da interpretação, em que "o efeito-leitor representa para o autor, sua exterioridade constitutiva (memória do dizer, repetição histórica)", deste modo, cada leitor tem uma história de leitura, o que torna impossível escrever sem considerar a alteridade constitutiva de toda produção de sentido.

Filiados à $\mathrm{AD}$, é importante lembrarmos que consideramos o sujeito em uma posição discursiva (PÊCHEUX, 2009), um sujeito social, heterogêneo e cindido. Segundo o autor, ao refletirmos sobre o conceito de sujeito discursivo, colocamos a ele as formações sociais, imaginárias, ideológicas e discursivas que o determinam, é um sujeito constituído por múltiplas vozes. Nesse sentido, compreendemos a escrita de Carolina Maria de Jesus a partir dessa posição-discursiva de autor.

Por isso, a importância de pensarmos a questão da autoria, em que, no caso de Carolina Maria de Jesus, ao ocupar a posição de sujeito-autor, conforme discutimos nos capítulos anteriores, ainda não encontrou um espaço na Literatura Brasileira, a com "L" maiúsculo, por conta de tratar de uma escrita de uma mulher, negra, pobre, favelada, aliás, estereótipos contra os quais Carolina lutou a vida toda para desvencilhar-se, não no sentido de negação do que se é, mas, sobretudo, para ter a garantia da legitimação da sua literatura, por sua vez, da sua autoria, assim como os autores consagrados, os "imortais".

A partir de todas essas considerações, procuraremos investigar o modo como Carolina Maria de Jesus, na posição de sujeito-autor, relaciona-se com a escrita em seus diários: Quarto de Despejo: diário de uma favelada (2014) e Diário de Bitita (2016). Isso porque compreendemos que a "fome" de/por leitura e escrita da autora, ajudam-nos a observar o modo como esse sujeito se constitui junto com/na escrita. 
Ressaltamos que em $\mathrm{AD}$, a questão da interpretação é inerente à linguagem, visto que a linguagem é exposta ao equívoco, e diz respeito ao não dito, à ausência. No arcabouço dessa teoria, a interpretação é vista como gesto, em contraposição a ato, gesto garantido pelo simbólico porque o sentido sempre pode vir a ser outro, dependendo da materialidade da língua e das relações que se estabelecerão entre os significantes em função das formações imaginárias, ideológicas e da historicidade que perpassa um dito ou um escrito.

Nesta primeira parte analisamos discursivamente alguns recortes da obra, Quarto de Despejo: diário de uma favelada (2014), em que é possível observar o poético em funcionamento por entre as "fomes" do sujeito-autor, o que consideramos como gestos de resistência.

O poético nesta dissertação é reconhecido por meio do corpo-textual poético (LEANDRO, 2016) articulado ao sentido patológico de corpo: o que é estrangeiro e estranho ao corpo, o que não faz parte ou não é conhecido pelo sistema, isto é, aquilo que faz produzir sentidos novos (rupturas) e se move pela subjetividade. O poético não se entrega a uma leitura esquemática, convencional, padronizada, cuja literalidade pretende um equilíbrio entre significante e significado. Ao contrário, temos um corpo-textual que aciona, alarma, que tira o sistema imunológico do funcionamento normal, que instala a polissemia e a possibilidade da autoria, visto que "o poeta seria apenas aquele que consegue levar essa propriedade da linguagem a seus últimos limites" (GADET; PÊCHEUX, 2004, p. 58).

É o corpo poético que toma o corpo propriamente dito, fazendo pensar, refletir, questionar, sentir, penetrar a vida simbolicamente, como podemos interpretar a partir dos recortes abaixo:

Recorte 1: 16 de julho:(...) Ganhei dois quilos de arroz, idem de feijão e dois quilos de macarrão. Fiquei contente. A perua foi-se embora. $\mathrm{O}$ nervoso interior que eu sentia ausentou-me. Aproveitei a minha calma interior para eu ler. (...) Li um conto. Quando iniciei outro urgiu os filhos pedindo pão (...) (JESUS, 2014, p.12).

Recorte 2: 19 de julho:(...) Cheguei em casa, fiz o almoço. Enquanto as panelas fervia eu escrevi um pouco (...) (JESUS, 2014, p. 19).

Recorte 3: 19 de julho:(...) Quando as mulheres feras invade o meu barraco, os meus filhos lhes joga pedra. Ela diz:

- Que crianças mal iducadas! Eu digo:

- Os meus filhos estão defendendo-me. Vocês são incultas, não pode compreender. Vou escrever um livro referente a favela. Hei de criar tudo que aqui se passa. E tudo que vocês me fazem. Eu quero escrever o livro, e vocês com estas cenas desagradáveis me fornecem os argumentos.

A Silvia pediu-me para retirar o seu nome do me livro. (...)

- Cato papel. Estou provando como vivo! (...) 
O dia de hoje me foi benefico. As rascoas da favela estão vendo eu escrever e sabe que lhe é contra elas (...). (JESUS, 2014, p. 20-21).

Nesses três recortes é possível observar que temos um sujeito-autor que luta em seu cotidiano contra as adversidades de uma vida miserável - resultado das condições materiais da favela - em que o cenário desse lugar, os acontecimentos, as relações sociais passam a fazer parte do projeto literário desse autor.

Nessa direção, a escrita é usada como um manifesto contra as mazelas deste espaço social, assim como gesto de resistência contra aqueles que perturbam o sujeito-autor. Escrever é "arma" de combate do sujeito-autor e a leitura o momento da sua "calma interior".

O projeto literário do sujeito-autor em (d)escrever, (d)enunciar as "cenas desagradáveis" da vida na favela passa a ser o ponto forte de argumentação (trama escrita), a ponto de os "moradores-feras" se sentirem inibidos com a escrita (recorte 3), pois esse "objeto" poderoso incomoda-os, intimida-os, dado seu poder de materialização e perpetuação do dizer.

A escrita ao materializar discursos, por sua vez, materializa sentidos; portanto, é poderosa e isso incomoda porque é um modo de desnudamento e implica deixar de ser invisível, o que azucrina "Silvia" e tantas outras moradoras e moradores da favela, que não desejam suas vidas e comportamentos discursivizados e expostos em um livro. Pensar a relação desigual de poder instaurada pela escrita, pelas mãos de uma autora que vive na favela potencializa a discussão, a nosso ver, sobre os efeitos que a posição de autor provoca naqueles que são alvos desse escrito.

O sujeito-autor "prova" a sua vida catando papel, metáfora para pensarmos em um sujeito que "ganha a vida" catando papel e, ao mesmo tempo, é pelo papel que sua escrita ganha materialidade. Papel no sentido literal, mas também papel no sentido de papeis sociais, neste caso, o de ocupar a posição de sujeito-autor, e também, a de mulher, mãe, negra.

Também podemos associar essa questão de "catar papel” com o que Fernandez (2015) designa de poética de resíduos, em que temos um sujeito-autor que, além de catar papel/papelão para sobreviver e materializar sua escrita nesses mesmos papeis, também cata palavras, ação tão importante para o sujeito-autor que precisa trabalhar o interdiscurso no intradiscurso a fim de se constituir sujeito-autor.

O modo como esse sujeito-autor cata palavras está sempre desembocando em um vir a ser, isto é, a polissemia está o tempo todo constituindo essa poética de resíduos que traz o inusitado para dentro de sua escrita, porosa, tendo os resíduos (as palavras, os 
papeis/papelões) como “emparelhamento, acumulação, improvisação e reutilização do descartável são molduras para a materialidade da obra" (FERNANDEZ, 2015, p. 68), isto é, as estratégias discursivas em que se traçam teias, resíduos, "chorume social malcheiroso" (idem, p. 134), em uma escrita que está sempre pronta para acontecer de novo, e de novo, e de novo, nesse diário, cotidiano, rotineiro da vida-favela(da).

Escrever está associado a uma formação discusiva que projeta um ideial de sujeitoescritor que precisa ocupar esse imaginário de "sujeito-culto" (recorte 3), já que a escrita não está autorizada a qualquer sujeito; todavia, esse sujeito-autor se autoriza a entrar na trama discursiva da escrita e a produzir (registrar) os acontecimentos cotidianos do cenário deplorável onde está inserido, causando rupturas na hierarquia de quem pode dizer ao ocupar uma posição privilegiada de poder.

A escrita é o meio e o fim que o sujeito-autor encontra para "falar de si", registrar a sua rotina. Escrita que se dá no intervalo das tarefas cotidianas "enquanto as panela fervia", em que discursivamente produz sentidos em relação ao fervor das panelas e o fervor da escrita, ações que acontecem ao mesmo tempo, na "roda viva" que não cessa de movimentar-se, sobretudo, porque escrever é resistir e inscrever os relatos da/sobre a vida que se quer registrada, denunciada, em que o sujeito-autor marca a sua subjetividade na/pela escrita.

Escrever é alimentação no sentido de "ação de escrever" a partir da "menção de si" como alimento necessário para a existência. $\mathrm{O}$ poético se instala porque em meio a um cotidiano que impede esse sujeito-autor de ter uma condição privilegiada para a escrita, o que há é uma produção literária que disputa com os afazeres da rotina doméstica e com a fome dos filhos. Durante a "calmaria" da leitura de um conto, tem os filhos "urgindo" por "pão". Pão esse que não se trata do "pão nosso de cada dia", porque ter "pão na mesa" é motivo de celebração, por sua vez, a "calmaria de leitura" também não o é, pois tudo dependerá, nesse caso, das condições materiais.

Recorte 4: 20 de julho: Deixei o leito as 4 horas para escrever. Abri a porta e contemplei o céu estrelado. Quando o astro-rei começou a despontar eu fui buscar água (...) (JESUS, 2014, p. 21).

Recorte 5: (...) 21 de julho: Dei banho nas crianças e preparei para sair. Fui catar papel. Mas estava indisposta. Vim embora porque o frio era demais. Quando cheguei em casa era 22,30. Liguei o rádio. Tomei banho. Esquentei comida. Li um pouco. Não sei dormir sem ler. Gosto de manusear um livro. O livro é a melhor invenção do homem. (JESUS, 2014, p. 24).

Recorte 6: 22 de julho:(...) Eu gosto de ficar dentro de casa, com as portas fechadas. 
Não gosto de ficar nas esquinas conversando. Gosto de ficar sozinha lendo. Ou escrevendo. (...) (JESUS, 2014, p. 25).

Recorte 7: 23 de julho: (...) Bateram na porta. Mandei o João José abrir e mandar entrar. Era o seu João, Perguntou-me onde encontrar folha de batatas para sua filha buchechar um dente (...) Quis saber o que eu escrevia. Eu disse ser o meu diario.

- Nunca vi uma preta gostar tanto de livros como você.

Todos tem um ideal. O meu é gostar de ler (...). (JESUS, 2014, p. 26).

Nestes recortes, podemos analisar o quanto a escrita desse sujeito-autor suscita curiosidades e incômodo às pessoas que vivem a seu redor. Afinal, pode uma mulher negra ser autor? A nosso ver, pode, sem dúvida; no entanto, o enfrentamento social desse sujeito é árduo.

Por enfrentamento social neste trabalho compreendemos um sujeito-autor que, a partir desta posição discursiva, enfrenta e disputa a legitimação de uma produção literária interditada frente à literatura canônica nacional, por meio de uma discursividade que ressalta outros enredos, ritmos, vocabulários, ressignificando outros modos de fazer literatura que contraria sentidos hegemônicos na língua, deste modo, vem daí o seu caráter marginal que abala e faz ranger a historiografia literária canônica, produzindo esse não-lugar na literatura brasileira e/ou afro-brasileira.

Carolina Maria de Jesus produz uma literatura de enfrentamento social porque materializa uma escritura que marca o seu projeto literário neste lugar da ruptura, do nãolugar, do impensado, a partir da produção de novos sentidos, em direção da denúncia social das mazelas de um país que se quer "debaixo do tapete", diríamos, silenciado, cuja visão não é “cheirosa", tampouco agradável.

A cor da pele do sujeito-autor (preta) não é apagada (recorte 7) porque há uma interdição do direito ao dizer para o sujeito-negro ("Nunca vi uma preta gostar tanto de livros como você”); nesse caso, a legitimação do dizer é concedida, autorizada a alguns (sujeitosbrancos) e interditada a outros (sujeitos-negros), a partir desse imaginário naturalizado pela ideologia, “(...) atribuindo valores sociais distintos que podem levar à segregação, em um imaginário em que o sujeito já está vinculado/significado, seja de que cor for" (ORLANDI, 2017, p. 97).

O sujeito ao dizer que nunca viu uma preta gostar tanto de livros (recorte 7) leva-nos a questionar: e o que uma preta (deve) gosta(r)? Temos aqui um discurso que se filia a uma formação discursiva racista, permeado por um imaginário que desqualifica a subjetividade da 
mulher-negra que está fadada a ser discursivizada pela construção social-histórica esteritipizada.

Todavia, o sujeito-autor resiste e se coloca no mundo a partir dessa posição discursiva, responsabilizando-se pelas suas escolhas no diário, ousando e assumindo, diante da sociedade, esse papel político-simbólico de autor, em que a escrita é a materialização dos seus ideais, trazendo o imponderável, o sentido fazendo um sentido outro.

É possível observar que o sujeito-autor é atravessado por uma multiplicidade de vozes que o torna "exótico", por meio de discursos que vêm de fora (do outro, Silvia, João) que tentam, a todo instante, interditar, inibir essa relação do sujeito-autor com a leitura e a escrita. Esse discurso de interdição à autoria constrói-se segundo uma formação imaginária que controla o deslocamento de uma formação discursiva para outra: Como pode uma mulher negra periférica gostar de ler e escrever?.

A escrita desse sujeito-autor ocorre nas oportunidades concedidas pela rotina (recorte 4) e é por essas brechas e rachaduras que o poético aparece. Leituras que se dão diariamente (recorte 5) antes de dormir e nos contratempos das tarefas do dia a dia, é uma escrita dos intervalos, espaço que permite a esse sujeito-autor a produção da sua literatura frente à resistência aos "imortais das letras" que se encontram numa posição privilegiada de legitimação. É na literatura que esse sujeito-autor marca a resistência e rompe com o clássicocanônico. A literatura é sua "arma de combate social” (FERNANDEZ, 2015).

O livro como potência simbólica disursiva da materialidade linguística do homem (recorte 5) faz com que a leitura e a escrita a "portas fechadas" (recorte 6) sejam a "pasárgada" do sujeito-autor, em que leitura e escrita são práticas de necessidades básicas para esse sujeito, como a alimentação, o trabalho, a moradia, um caso urgente de "ser" e constituir-se na rotina (miserável) da vida pela escrita, a sobre-vivência resistida na/pela leitura e escrita. E por tratar de uma necessidade básica, precisa ser reconhecida como um Direito Humano (CANDIDO, 1988).

Merece destaque o modo como o sujeito-autor seleciona o que colocar em seu diário acontecimentos cotidianos, aparentemente banais - a partir de uma descrição densa e repetitiva dos afazeres rotineiros. A poesia escorre justamente desses espaços em que as ações do dia a dia são "regadas" pela leitura e pela escrita. O diário passa a ser o "lugar" de onde é possível "brotar" o inesperado, o que faz falhar com as repetições das ações rotineiras, porque é um meio de respiro, caminho possível de resistência frente a uma condição de produção que 
interdita o direito à leitura e à escrita o tempo todo (sujeito-autor negro não pode constituir-se como autor de literatura).

No recorte 6, o sujeito-autor ao assumir o seu "ideal" de vida frente ao seu interlocutor, ao invés de dizer que tem o ideal de escrever, diz que é o de ler. Temos, aparentemente, uma contradição, visto que de acordo com o curso da interlocução poderíamos pressupor que a resposta do sujeito-autor é ter um ideal de escrever; todavia, a formulação "ideal de ler" indicia-nos um dos princípios de autoria, isto é, o movimento que o sujeitoautor realiza entre as posições de escritor e autor de seu texto, porque é pela leitura que o sujeito tem acesso ao interdiscurso e são os ecos do interdiscurso que entretecem os fios do intradiscurso, cuja responsabilidade pela construção é do autor.

A literatura se pluraliza nos escritos desse sujeito-autor porque não se fecha em um conceito de "escrita difícil", "para poucos", "dos irmortais das academias de letras", canonizada/mumificada. Antes, o sujeito-autor subjetiva a sua autoria ao inscrever a ilusão tão necessária de unidade ao seu discurso, em que os afazeres da rotina, que são quase sempre os mesmos, repetem-se porque não há outro modo de escapar dessas condições materiais de produção; no entanto, as condições de produção discursivas são outras, pois embora a favela seja materialmente miserável, a relação que o sujeito constrói com a leitura, escrita e interpretação ultrapassa os limites empíricos do "quarto de despejo" e, pelo acesso à memória discursiva, aos textos lidos, aos sentidos já produzidos, o sujeito-autor consegue discursivizar o dia a dia miserável, mas também, a possibilidade de contemplar o "céu estrelado" (recorte 4), o qual, aparentemente, é para todos. Deste modo, em meio ao insalubre, o poético instalase pelo viés da resistência.

Em meio às contradições que constituem sujeito e sentidos, o sujeito-autor não silencia a questão do preconceito e discriminação social contra sua condição de autor, posto que ele vale-se disso para, literariamente, denunciá-lo, de tal modo que “(...) o próprio preconceito, a discriminação racial, tornem temas de suas obras, apontando-lhes as contradições e as consequências" (CUTI, 2010, p. 25).

O sujeito-autor, em especial nos dois últimos recortes (6 e 7), materializa a contradição presente no discurso preconceituoso vindo do outro, que também é pobre e favelado, mas filia-se à formação discursiva que procura deslegitimar a posição discursiva do sujeito-autor resistência. Temos, aqui, o funcionamento da contradição, conforme apontada por Pêcheux (2009). 
A mesma língua que sustenta o preconceito do branco contra os pobres, negros e favelados é usada por aqueles que sofrem o preconceito de modo a legitimá-lo, ou seja, o sujeito da favela filia-se à formação discursiva dominante sobre o que é um autor e quem pode ser autor e, capturado pela ideologia dominante, tenta destituir seu par (mulher negra, pobre e favelada) dessa posição discursiva de sujeito-autor resistência.

Diante disso, o sujeito-autor ao escrever "demarca o ponto diferenciado de emanação do discurso, o "lugar" de onde fala" (CUTI, 2010), e isso importa porque a política literária legitima e/ou interdita atrelada, também, a preconceitos e discriminações.

Nesse sentido, o sujeito-autor negro (não no sentido empírico analisado por Cuti) ao se autorizar a dizer investe na sua humanização e no seu direito à fala, combatendo o preconceito e a discriminação que invadem e interditam a sua escrita, em que o que está nas bordas, nas margens, emerge ao centro e disputa a autorização do dizer por meio da resistência pelo poético.

A presença do sujeito-negro na literatura, segundo Proença Filho (2010, p. 43) não escapa do tratamento marginalizador marcado pela etnia no processo de construção da sociedade. Para ele, há dois posicionamentos gerais quando se trata da trajetória no discurso literário nacional: 1 . A condição negra como objeto, numa visão distanciada; 2 . O negro como sujeito, numa visão compromissada.

No posicionamento 1, o sujeito-negro é visto como objeto em uma visão distanciada, configurado em textos nos quais o sujeito-negro ou o descendente deste era reconhecido como tal personagem, discursivizado por meio de formações imaginárias e ideológicas a partir de uma visão-estética eurocêntrica repleta de estereótipos, descompromissado com a emancipação do sujeito-negro reconhecido como sujeito de direitos.

Nesse posicionamento, o negro é discursivizado como: 1 . O escravo nobre, que vence por força de seu processo de branqueamento, embora a custo de muito sacrifício e humilhação, caso da obra Escrava Isaura, escrito por Bernardo Guimarães, publicado em 1872, e de $O$ mulato, Aluísio de Azevedo, lançado em 1881. 2. A do negro vítima, sobretudo quando escravizado, em que "nessa óptica, ele se transfigura em objeto de idealização, pretexto para a exaltação da liberdade e da causa abolicionista" (PROENÇA FILHO, 2010, p. 45), é o caso da poesia romântica - O navio negreiro - de Castro Alves. 3. O negro infantilizado, em que é um serviçal e subalterno, encontrado, por exemplo, em peças de teatro como $O$ demônio familiar, de José de Alencar, e $O$ cego, de Joaquim Manuel de Macedo; 4. O 
negro pervertido, em obras como O bom crioulo (1885), de Adolfo Caminha, uma história de homossexualidade, corajosíssima para aquele contexto histórico; e em A carne (1888), de Júlio Ribeiro, em que, segundo o narrador, Lenita, personagem branca, liberava seus instintos por causa da promiscuidade dos escravizados. 5. A figura do negro exilado na cultura brasileira encontrado na obra Urucungo (1933), no livro de poemas de Raul Bopp.

Como podemos observar, no âmbito do distanciamento caracterizado por Proença Filho (2010), sem chances de ser esgotado, em todas as cinco considerações discursivas a respeito da representação do negro em relação à produção literária dos últimos séculos, predomina, sobretudo, a estereotipação dos sujeitos-negros quase sempre nesse lugar da subalternidade e objetificação. O personagem negro ou descendente, ora ganha presença como "elemento perturbador" do equilíbrio familiar ou social; ora como negro heroico, humanizado, amante, força de trabalho produtivo, vítima sofrida de sua ascendência, em que, segundo o autor, Zumbi e a saga quilombola, por exemplo, não fazem parte desse discurso literário, pois:

Essa poetização da figura do negro, mais configurada nas manifestações literárias do século XIX, culminou por tornar-se, segundo penso, uma faca de dois gumes: se, como quer ainda o mesmo Antonio Candido, conseguiu impor a dignidade humana do negro, por outro lado, passou a ser uma via de saída confortável para o preconceito presente na realidade brasileira, na medida em que acabou escoando na aceitação do negro e do mestiço de negro reconhecido como tal enquanto emocionalmente e socialmente bem comportados, dóceis, resignados e que, como Isaura, sabem reconhecer o seu lugar que socialmente lhes foi imposto. (PROENÇA FILHO, 2010, p. 55).

No entanto, na posição 2: o negro como sujeito, uma atitude compromissada, Proença Filho (2010) cita alguns autores pioneiros pertencentes a essa posição como Luís Gama (1850 -1882); Lima Barreto (1881 - 1922); Solano Trindade (1908 - 1973); entre tantos outros, que apresentam em seus escritos um compromisso com a etnia, por meio de um posicionamento engajado de resistência e luta pela afirmação e reconhecimento social das suas posições de sujeitos-autores e suas produções literárias, em que, de acordo com o autor, no âmbito da literatura-testemunho, a voz de Carolina Maria Jesus, na posição de sujeito- autor, ganha eco por meio de suas obras, já que quebra a objetificação do negro apresentada no posicionamento 1. Analisemos outros recortes:

Recorte 8: 12 de junho: Eu deixei o leito as 3 da manhã porque quando a gente perde o sono começa pensar nas misérias que nos rodeia (...) Deixei o leito para escrever. Enquanto escrevo vou pensando que resido num castelo cor de ouro que 
reluz na luz do sol. Que as janelas são de prata e as luzes brilhantes. Que a minha vista circula no jardim eu contemplo as flores de todas as qualidades (...) É preciso criar esse ambiente de fantasia, para esquecer que estou na favela. (...) (JESUS, 2014, p. 58).

Recorte 9: 19 de julho: (...) Hoje eu não lavo roupas porque não tenho dinheiro para comprar sabão. Vou ler e escrever. (...) (JESUS, 2014, p. 95).

Recorte 10: 18 de julho: (...) Segui pensando: quem escreve gosta de coisas bonitas. Eu só encontro tristezas e lamentos”. (JESUS, 2014, p. 184).

Recorte 11: 15 de maio: (...) Eu classifico São Paulo assim: O Palacio, é a sala de visitas. A prefeitura é a sala de jantar e a cidade é o jardim. E a favela é o quintal onde jogam os lixos (...) A noite está tépida. O céu já está salpicando nas estrelas. Eu que sou exótica gostaria de recortar um pedaço do céu para fazer um vestido (...) (JESUS, 2014, p. 32).

Nestes recortes, principalmente o 8 e o 11, indiciam um sujeito-autor que materializa na escrita - diário - o poético, por meio da produção de um cenário outro, construído segundo um imaginário que poderia ser comparado ao dos contos de fadas; contudo, o sujeito não se deixa levar por esse imaginário de "final feliz" e escreve "Eu só encontro tristezas e lamentos" (recorte 10), o que nos permite refletir que quem escreve nem sempre gosta de "coisas bonitas", afinal, escrever também dói, ainda mais quando é utilizada para denunciar a miséria das "faltas", isto é, as "fomes".

É pela escrita que o movimento discursivo - castelo cor de ouro, janelas de prata, jardim, pedaço do céu para fazer um vestido - possibiltita a assunção da autoria em sentidos que partem em diferentes direções, desorganizando a paráfrase, produzindo a polissemia por meio de um “(...) processo transformador, de rupturas e de trabalho ideológico, inconsciente, na relação do sujeito consigo mesmo e com o outro" (ORLANDI, 2017, p. 104).

Isso nos leva a refletir sobre a importância da literatura na vida de um sujeito, lugar do feio (favela), mas também lugar do bonito (a polissemia). É nesse sentido que compreendemos a escrita desse sujeito-autor como resistência, porque pela materialidade da língua esse sujeito transgride a limitação de uma existência, pois "É preciso criar esse ambiente de fantasia, para esquecer que estou na favela"; quem escreve também gosta de "coisas bonitas" (recorte 10), gesto esse de resistência articulada pelo/no poético, do giro na língua.

Na miséria da falta material (recorte 9), a escrita é sempre o lugar onde o sujeito-autor se refugia, escapa, devaneia, estabelecendo a sua relação com o simbólico, em que "a inscrição do sujeito na letra é um gesto simbólico-histórico que lhe dá unidade, corpo, no corpo social” (ORLANDI, 2006, p. 24). 
O sujeito-autor instala sua textualidade individualizando-se pelo gesto da escritura de si, reconhecendo-se no seu desejo de ser. Pela escrita esse sujeito-autor discursiviza (movimenta) os sentidos a respeito da sociedade que o cerca, sua recusa, seu desacordo, sua rebelião, sua revolta, sobretudo, o seu gesto discursivo de resistência de quem, pela linguagem, materializa seus (outros) desejos para além da limitação da sua condição social de mulher, negra, pobre, favelada.

Pela literatura, a geografia da cidade é materializada também pelo poético (recorte 11), o pálácio (sala de visitas), a prefeitura (sala de jantar) e a cidade (o jardim), compõem o cenário paisagístico do bonito, belo; contudo, dentro desse mesmo espaço, também habita o disforme, o feio, onde jogam os lixos e moram os sujeitos-excluídos: a favela (quintal).

No espaço geográfico mal-apessoado se encontra o sujeito-autor e é desse lugar que seu discurso literário parte, o que acarreta na exotificação desse sujeito, pois a ideologia naturaliza e fixa uma imagem ideal do que é um autor de literatura, um sujeito que, diante das noites tépidas, está inserido nesse “entre-mundos”. Espaços simbólicos de poder, de exclusão e de contradição, pois na zona do feio também é possível encontrar autoria, fissuras dessa interpenetração do jogo discursivo do feio (que tem algo de belo), do belo (que tem algo de feio).

Recorte 12: 8 de julho: (...) As quatro horas comecei a escrever. Quando eu desperto custo a adormecer (...) É que eu ganhei umas tabuas e vou fazer um quartinho para eu escrever e guardar meus livros (...) (JESUS, 2014, p. 86).

Recorte 13: 20 de julho: (...) Eu estava escrevendo quando ouvi a voz do senhor Binitito. Mandei ele entrar. Ele conduziu um senhor do Centro Espirita Divino Mestre, localisado na rua Oriente, que veio dar cartão para a gente buscar agasalho para as crianças, dia 23. Fiquei tão contente que saí da cama com rapidez. E expliquei ao senhor o que escrevo.

Ia recomeçar a escrever quando o Adalberto chegou (...)

Era 1 hora quando eu ia recomeçar a escrever.

O senhor Alexandre começou a bater na sua esposa (...).

Deitamos. Eu estava agitada e nervosa porque queria passar o dia escrevendo. (...) (JESUS, p. 96-97).

Recorte 14: 27 de julho: (...) Esquentei a comida para os meninos e comecei a escrever. Procurei um lugar para eu escrever sucegada. Mas aqui na favela não tem esses lugares. No sol eu sentia calor. Na sombra eu sentia frio. Eu estava girando com os cadernos na mão quando ouvi vozes alteradas. Fui ver o que era, percebi que era briga. (...) (JESUS, 2014, p. 101).

É possível observar neste recorte (12), mais uma vez, o quanto a escrita para esse sujeitoautor está presente, desde ao acordar até o dormir. É só aparecer na escrita do intervalo um 
espaço de respiro perante as tarefas da rotina que o sujeito-autor aproveita para escrever. Escrita de quem também é leitor, nesse sentido, o sujeito-autor, mesmo permeado por condições materiais tão precárias (favela, papelão, barraco), encontra meios de ter o seu espaço para os livros (quartinho) e para a escrita. Quartinho que é construído a partir de outro quarto (o do despejo, barraco da favela, seu lar).

Esse nosso gesto de interpretação nos remete à poesia presente em uma fotografia registrada por um fotógrafo amador, Valter Rodrigues Júnior, no dia 28 de maio de 2017, que causou comoção nas redes sociais (Facebook, Twitter). Pelo fato de dialogar com o que estamos analisando, consideramos pertinente trazer a fotografia, nessa seção. A imagem é de uma menina de apenas oito anos de idade agarrada a uma mochila com os livros da escola enquanto é resgatada da enchente no interior de Pernambuco. Segundo a fonte do site $U O L^{5}$, a garota, identificada como Rivânia, ao ser aconselhada pela avó a pegar o que fosse mais importante antes de subir na balsa, escolheu os livros. O caso aconteceu no distrito de Várzea do Uma, em São José da Coroa Grande.

A imagem da garota (Rivânia) agarrada aos livros sugere o quanto a leitura constitui esse sujeito, subjetividade que encontramos em Carolina Maria de Jesus que, na posição de sujeitoautor, "agarra-se" ao mundo da escrita e da leitura como resistência, a ponto de o ato de "salvar os livros" significa salvar a si mesmo.

No Jornal da Tribuna ${ }^{6}$, Rivânia Ramos Silva é entrevistada e ao ser questionada pela repórter, acerca do motivo de ter salvado os livros, ela diz que é nos livros que está o seu futuro: o desejo de ser professora. Discurso revolucionário em um país onde a valorização do trabalho do professor ficou em último lugar no ranking de prestígio, segundo reportagem da Carta Capital, no dia 08 de novembro de 2018.

Ainda durante a reportagem do Jornal da Tribuna, em decorrência da divulgação da fotografia, diversas pessoas do país e fora se mobilizaram em contribuir com bens materiais, dentre eles livros, cadernos, lápis, para a Rivânia e sua família. No final da reportagem, a repórter pergunta para Rivânia o que gostaria de ganhar e a garota responde: uma casa. Desejo também de Carolina Maria de Jesus quando residia na favela, porque a casa é um Direito

\footnotetext{
5 Menina salva os livros de enchente em Pernambuco e foto comove a web. https://www.uol.com.br/. 01/06/2017. Disponível em: < https://noticias.uol.com.br/cotidiano/ultimas-noticias/2017/06/01/menina-salvalivros-de-enchente-em-pernambuco-e-foto-comove-a-web.htm> Acessado em 22 de outubro de 2018.

${ }^{6}$ Garota comove internet ao salvar os livros de enchente. https://www.youtube.com/. 08/06/2017. Disónível em: https://www.youtube.com/watch?v=3I-5mtI8xb0. Acessado em 22 de outubro de 2018.
} 
Humano, lugar onde os livros podem ser "salvos", acolhidos, guardados.

Figura 3 - Rivânia salva os livros

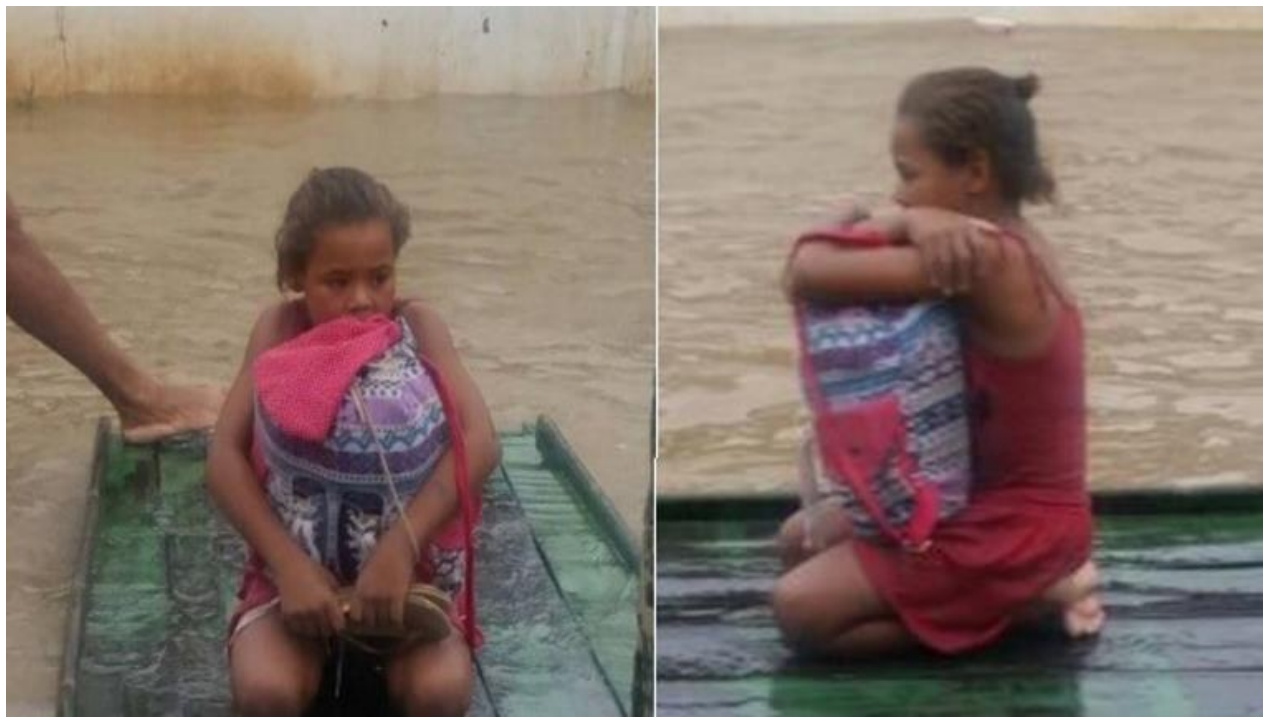

Fonte: RODRIGUES (2017) ${ }^{7}$

No entanto, em uma sociedade do espetáculo, a nosso ver a reportagem contribui para a “espetacularização da pobreza", visto que são reportagens que buscam entretenimento e ibope. O mesmo pode ser observado em Carolina Maria de Jesus que, na década de 1960, ao publicar sua primeira obra, chamou a atenção de diversos meios de comunicação (revistas, jornais, artigos científicos, rádio, entre outros) por causa da "estranheza" de ocupar a posição sujeito-autor sendo mulher, negra, favelada.

Como procuramos mostrar nos capítulos anteriores, a política literária, no funcionamento discursivo atrelado ao mercado editorial, a obra Quarto de Despejo: diário de uma favelada (2014), de Carolina Maria de Jesus, aparentemente ganha notoriedade mais pelo espetáculo da vida na favela, do que como literatura. Carolina Maria de Jesus passa a participar de entrevistas nos jornais, rádios, televisão, porque sua escrita importa como artigo de consumo, protagonizando o bicho estranho favelado que se exibe, isto é, a "espetacularização da pobreza", como se fossem vidas e histórias distanciadas da realidade cotidiana social. Ao

\footnotetext{
7 Disponível em: < https://noticias.uol.com.br/cotidiano/ultimas-noticias/2017/06/01/menina-salva-livros-deenchente-em-pernambuco-e-foto-comove-a-web.htm> Acessado em 22 de outubro de 2018.
} 
mercado importa a pobreza que vende porque é geradora de lucros.

No entanto, refutamos esse discurso que a "espetacularização" da vida na favela é a única via que fez (e faz) Carolina Maria de Jesus constituir-se como sujeito-autor na contemporaneidade, pois cada vez mais, os meios acadêmicos, mesmo que poucos, têm descoberto outras facetas dessa autora para além do cenário da favela, em uma multiplicidade de gêneros literários e não literários que compõem o acervo do espólio de Carolina "reafirmando a teia radicular e conflitante das buscas que alimentam a re-invenção, sua poética de resíduos" (FERNANDEZ, 2015, p. 252) desse sujeito-autor, por meio de uma "escrita de si", mas também de um sujeito que tenta desvincilhar-se desse "vício estilístico", produzindo uma literatura que passeia por diversos gêneros discursivos.

A história de Rivânia Ramos Silva se entrelaça com a de Carolina Maria de Jesus, por serem mulheres, negras, periféricas, gostarem de ler e valorizarem os livros em suas vidas. Também pelos anseios: Carolina anseia, durante a sua vida na favela de Canindé, São Paulo, a conquista de uma casa própria longe daquele lugar. Rivânia e Carolina conquistam a casa própria pelo amor aos livros, mas, sobretudo, por resistirem a um cenário permeado pela pobreza, são personagens e protagonistas de suas próprias histórias, naquilo que Conceição Evaristo (2010) chama de "escrevivências", isto é, a escrevivência que não pode ser lida como histórias para ninar os da casa grande, e sim, para incomodá-los dos seus sonos injustos, discurso da/sobre a pobreza por fugir das narrativas cotidianas parafrásticas sobre as misérias que ainda assolam/assombram o país. Paráfrase que indicia o mesmo, o repetível de uma doença social que ainda não foi superada.

O sujeito-autor, na escrita dos intervalos, registra o cotidiano da favela (recorte 13), cotidiano esse ora feliz, ganhar agasalhos; ora irritante, porque quando recomeça a escrever o outro (Adalberto, o senhor Alexandre) tornam a atrapalhar esse momento de escrita. Deste modo, todos esses acontecimentos vão compondo a narratividade do sujeito-autor, a alegria do agasalho, a agitação e nervosismo por ter que interromper a escrita, em um ambiente onde não há a presença de um Bach, Beethoven, Mozart, Vivaldi, compositores de música clássica que poderiam construir um cenário tranquilo para os escritos da autora. Envolta no cenário dos vizinhos, o som presente é o das brigas (Senhor Alexandre batendo na esposa), opereta do horror (também presente no recorte 14), em que a busca por um lugar sossegado não existe na favela, metáfora da "enchente", que o sujeito-autor, ainda assim, enfrenta e resiste, "girando os cadernos" na "gira do mundo", por meio da leitura e da escrita a fim de não se deixar 
naufragar, resistência do/pelo poético.

Recorte 15: 2 de junho: (...) O senhor Manuel apareceu dizendo que quer casar-se comigo. Mas eu não quero porque já estou na maturidade. E depois, um homem não há de gostar de uma mulher que não pode passar sem ler. E que levanta para escrever. E que deita com lápis e papel debaixo do travesseiro. Por isso eu prefiro viver só para o meu ideal (...) (JESUS, 2014, p. 49).

Recorte 16: 26 de julho: (...) Eu disse ao senhor Manoel que passaria a noite escrevendo. Ele despediu-se (...). (JESUS, 2014, p. 101).

Recorte 17: 16 de junho: (...) Eu escrevia peças e apresentava aos diretores de circos. Eles respondia-me: - É uma pena você ser preta. Esquecendo eles que eu adoro a minha pele negra, e o meu cabelo rústico. Eu até acho o cabelo de negro mais iducado do que o cabelo do branco. Porque o cabelo de preto onde põe, fica. É obediente. E o cabelo do branco, é só dar um movimento na cabeça ele já sai do lugar. É indisciplinado. Se é que existe reencarnações, eu quero voltar sempre preta. (...) (JESUS, 2014, p. 64).

Recorte 18: 14 de julho: (...) O José Carolos ouviu a Florenciana dizer que eu pareço louca. Que escrevo e não ganho nada. (...) (JESUS, 2014, p. 93).

Ao concordamos com Davis (2016) em que há a construção de uma nova utopia pelas mulheres negras, isto é, aquela do posicionamento $n^{\circ}$ 2, de Proença Filho (2010), ou seja, o negro como sujeito, levantamos uma reflexão necessária e importante a respeito do modo como as opressões se combinam e se entrecruzam, o que nos ajuda a interpretar os recortes acima, porque, como podemos observar, no recorte 15 , o sujeito-autor argumenta o quanto ocupar essa posição incomoda o outro (masculino, patriarcal), fugindo mais uma vez de um imaginário de autor, pois não se trata de um sujeito-autor homem, muito menos branco (recorte 17), portanto, só pode tratar de um sujeito-louco porque escreve e ainda não ganha nada (recorte 18).

A visão utilitarista em relação à literatura é muito recorrente, ainda mais na escola, em que se serve dessa justificativa como argumento do desinteresse e falta de empenho da garantia ao direito à literatura na sala de aula. Também é importante observar que o sujeitoautor ao fazer a escolha pelo papel e o lápis tem de viver esse ideal sozinho, porque os homens não hão de querer um sujeito que vivencia esse ideal, que passa a noite escrevendo (recorte 16).

O recorte 17 remete a uma discussão importante sobre a autoria: a publicação dos escritos, já que o sujeito-autor, viabilizado pela escrita, expõe ao olhar do outro os seus escritos, abrindo espaço para a leitura, consequentemente, aos gestos de interpretação e efeitos de sentidos por parte do sujeito-leitor. Deste modo, o sujeito-autor tem uma responsabilidade 
por aquilo que escreve e publica, já que:

(...) Por um lado, o autor é sempre aquele que, de alguma maneira, está autorizado a dizer. Mas, por outro lado e simultaneamente, para ser autor é preciso que o sujeito autorize-se a dizer, permita-se trazer à tona, à superfície do papel (ou da tela do computador) aquilo que lhe diz respeito, mas também o que diz respeito aos outros a quem dirige. Também ele precisa autorizar o seu texto a circular publicamente. Esta é também uma decisão. Embora, todo texto possa furtar-se, por contingências diversas, ao controle e poder do seu autor. (RODRIGUES, 2011, p. 21).

Ainda sobre esse recorte, temos um sujeito-autor e a busca de meios para publicação de seus escritos; no entanto, a política literária entra em funcionamento, interditando os escritos e a autoria desse autor, pois há formações imaginárias sobre o que seja um autor e elas não permitem que o autor das margens conquiste o centro (a publicização).

Violação que suscita sentidos sobre a importância da desnaturalização desse ideial de autor que impede o discurso polêmico (ORLANDI, 2012) e reclama um debate sobre os “processos de colonização do poder, do ser e do saber presentes na estrutura, no imaginário social e pedagógico latino-americano e de outras regiões do mundo" (GOMES, 2017, p. 16), que interdita a autoria do sujeito-negro.

Para Gomes (2017) é, sobretudo, por meio do Movimento Negro Brasileiro - movimento social heterogêneo - que as discussões sobre racismo, discriminação racial, desigualdade racial, crítica à democracia racial, gênero e juventude, ações afirmativas, africanidades, intolerância religiosa contra as matrizes afro-brasileiras, questões quilombolas, saúde da população negra, teorias e interpretações críticas pautadas sobre a temática racial no campo acadêmico ganham visibilidades.

No espaço acadêmico, segundo a autora, é por meio de encontros, palestras, publicações, minicursos, projetos de extensão, ciclo de debates abertos à comunidade, panfletos, revistas, livros, sites, canais no YouTube, blog, páginas nas redes sociais, artes, literatura, entre outros, que a temática racial no Brasil, em sintonia com a diáspora africana, tem deixado de ser silenciada, isso tudo por causa do Movimento Negro educador:

(...) tem sido esse mesmo movimento social o principal protagonista para que as ações afirmativas se transformassem em questão social, acadêmica e jurídica em nossa sociedade, compreendidas como políticas de correção de desigualdades raciais desenvolvidas pelo Estado brasileiro. É também o Movimento Negro responsável por trazer a arte, a corporiedade, o cabelo crespo, as cores da África para o campo da estética, da beleza, do reconhecimento e da representatividade. (GOMES, 2017, p. $18)$. 
Muito do que se produz sobre a temática racial e africana, atualmente, é em busca de uma perspectiva crítica e emancipatória (GOMES, 2017). O racismo como crime inafiançável na Constituição Federal e a obrigatoriedade do estudo da história e cultura afro-brasileira e africana nas escolas públicas e particulares da Educação Básica contribuem para a formulação de práticas antirracistas e de combate. No entanto, há todo um processo sócio-históricoideológico que tenta silenciar a resitência dos sujeitos-negros, naturalizando discursos/práticas racistas.

Por isso, concordamos com Gomes (2017) ao reconhecer o Movimento Negro como sujeito político produtor e produto de experiências sociais diversas (re)significando as questões étnico-racial em nossa história, reconhecido como sujeito de conhecimento, por isso a importância da pedagogia da ausências e emergências em transformar as ausências (temática racial e africana) em presenças, posicionamento de vigilância epistemológica no que se refere ao campo de produção do conhecimento educacional (GOMES, 2017, p. 63) que precisa compreender que a "escola além de reproduzir a ideologia dominante também possibilita a crítica a essa ideologia" (FREIRE, 2018, p. 44).

É nesse sentido que consideramos a literatura de Carolina Maria de Jesus como parte da produção das discussões que precisam estar presentes, em especial, na escola, cuja reflexão crítica, histórica, social e ideológica deveria ser um dos aspectos principais do currículo escolar, tendo uma de suas tarefas "decifrar o mundo opressor para o oprimido: por isso que esse trabalho é político" (FREIRE, 2018, p. 57).

Carolina ao ocupar a posição de sujeito-autor mobiliza gestos de leitura que por muito tempo têm sido naturalizados pela ideologia dominante, por exemplo, a questão do corpo negro como corpo objetificado, desprovido da estética de beleza dominante e, também, no caso das mulheres negras, ainda há o debate sobre o cabelo crespo.

A Marcha Nacional das Mulheres Negras, 2015, contra o racismo e o bem-viver, no dia 18 de novembro, em Brasília, deu mais visibilidade a respeito da situação de desigualdade e violência de gênero e raça que incidem sobre as mulheres, jovens e meninas negras, unindo as alianças internacionais das mulheres negras latino-americanas e de outros continentes. De acordo com Gomes $(2017$, p. 74), as mulheres negras também trouxeram como tema de denúncia e de luta a violência que atinge as comunidades quilombolas, a intolerância religiosa, o extermínio da juventude negra, a LGBTfobia, o feminicídio das mulheres negras e a ditadura da beleza eurocentrada. É, em especial, sobre esse último que queremos nos 
debruçar com mais atenção.

Ainda no recorte 17, o sujeito-autor, ao tentar publicar seus escritos, é barrado pelo fato de ser preta, em que pesam a cor da pele negra e o cabelo crespo. Há uma interdição da política literária funcionando sustentada no discurso de preconceito racial, por meio de uma ideologia dominante que desconsidera o corpo-negro, ainda mais, na posição de sujeito- autor. Gomes (2018) trata disso no que ela chama de saberes estético-corpóreos, ligados às questões da corporeidade e da estética negras. A autora escreve que:

(...) Trata-se da negação do corpo negro como corpo livre, que age, move, contesta, vibra, goza, sonha, reage, resiste e luta. No limite, é a produção do corpo negro como não existência. Podemos dizer que estamos diante de uma forma de regulação do corpo negro que se dá por meio da violência do racismo que afeta todos nós, inclusive as suas próprias vítimas. (GOMES, 2017, p. 79).

A autora argumenta que as ações afirmativas permitiram que os sujeitos-negros, sobretudo, as juventudes, possam aprender a ter orgulho de ser negro, de seus corpos e, pela maioria ocupar espaços periféricos, a também não se envergonharem disso, numa postura afirmativa. É nesse sentido que os saberes estético-corpóreos vão muito além da estética da arte, mas "a estética como forma de sentir o mundo, como corporeidade, como forma de viver o corpo no mundo" (GOMES, 2017, p. 79), e é nisso que acreditamos que a literatura da Carolina Maria de Jesus contribui, para que essa discussão esteja presente, em que a beleza negra ultrapassa a questão da fisicalidade e adquire um sentido simbólico e político (idem, p. 83), no caso do sujeito-autor, a afirmação do cabelo é um modo de percebermos a resistência desse sujeito perante a violência racista do outro, isso porque não podemos nos esquecer de que "nos primórdios da colonização, a África negra foi considerada um deserto cultural, e seus habitantes como o elo entre o homem e o macaco" (ibidem, 2017, p.82), portanto, sujeito-autor não só aceita a sua cor de pele e cabelo, como também transforma o seu corpo em um ato discursivo político ("Eu até acho o cabelo de negro mais iducado do que o cabelo do branco. Porque o cabelo de preto onde põe, fica. É obediente. E o cabelo do branco, é só dar um movimento na cabeça ele já sai do lugar. É indisciplinado. Se é que existe reencarnações, eu quero voltar sempre preta.")

Essas discussões da representatividade do corpo negro, encontrado no discurso literário de Carolina Maria de Jesus, na posição de sujeito-autor, fazem com que sua literatura seja de resistência, porque não silencia as discussões de temática racial, antes, denuncia-nas. Também 
é por esse motivo que acreditamos na importância da escola levar para o seu espaço a literatura de autoria de mulheres negras, porque suscita, por meio do discurso literário, uma oportunidade de acesso a uma literatura que rompe com um sistema de cânone fechado, cristalizado, suscitando outros modos de pensar e reconhecer a literatura, permitindo que as pautas étnico-raciais se desloquem da paráfrase, do mesmo, do repetível, para a polissemia, para a crítica e a emancipação, especialmente, por meio da literatura e de seus espaços vazados.

É literatura de resistência porque traz discursos perigosos e poderosos, jogando o jogo da política literária, ora contribuindo para a sua desestabilização conceitual do que seja literatura, por sua vez, cânone; ora contribuindo para legitimar, pela mesma política literária, novos modos de produzir a literatura, pluralizando-a, a partir da garantia do direito à literatura (CANDIDO, 1988).

A literatura de autoria de mulheres negras também não pode ser sedimentada como pretexto para a discussão única e exclusivamente sobre questões étnico-raciais, porque, como toda literatura, é repleta de espaços vazados (BRAGATTO FILHO, 1995), condição mesma da incompletude da linguagem.

As literaturas das bordas emergem, disputam o centro, a visibilidade e se deseja reconhecida socialmente, não por meio de nomeações outras, que procuram, ilusoriamente, por um efeito de sentido que acaba indo para o mesmo lugar que se critica (literatura eurocêntrica) mas, literatura negra, afro-brasileira e ou afrodescendente, periférica, ou como procuramos defender nesta dissertação: literatura de autoria negra, pluralizando as literaturas, disputando dizeres, saberes, estéticas, poéticas e narrativas.

Recorte 19: 6 de janeiro: (...) - Tem banha?

- Não tem.

- Tem carne?

- Não tem.

Entrou um japonês e perguntou:

- Tem banha?

Ela esperou eu sair para dizer-lhe:

- Tem.

Voltei para a favela furiosa. Então o dinheiro do favelado não tem valor?

Pensei: Hoje eu vou escrever e vou chinga a caixa desgraçada do Açougue Bom Jardim!

Ordinaria. (JESUS, 2014, p. 151).

Recorte 20: 19 de maio: Deixei o leito as 5 horas. Os pardais estão iniciando a sua sinfonia matinal. As aves deve ser mais feliz que nós. Talvez entre elas reine amizade e igualdade (...) O mundo das aves deve ser melhor do que dos favelados, que deitam e não dormem porque não tem o que comer. (...) 
Quando estou na cidade tenho a impressão que estou na sala de visita com seus lustres e cristais, seus tapetes de viludos, almofadas de setim. E quando estou na favela tenho a impressão que sou objeto fora de uso, digno de estar num quarto de despejo. (JESUS, 2014, p. 35).

Recorte 21: 21 de maio: (...) Quem deve dirigir o Brasil é quem tem capacidade. Quem tem dó e amisade ao povo. Quem governa o nosso país é quem tem dinheiro, quem não sabe o que é fome, a dor, e a aflição do pobre. Se a maioria revoltar-se, o que pode fazer a minoria? Eu estou ao lado do pobre, que é o braço. Braço desnutrido. Precisamos livrar o paiz dos políticos açambarcadores. (...) (JESUS, 2014, p. 39).

Recorte 22: 7 de outubro: Morreu um menino aqui na favela. Tinha dois anos. Se vivesse ia passar fome. (JESUS, 2014, p. 124).

A capacidade de ler o mundo, e não, simplesmente, de ler textos, daquilo que Paulo Freire (2018, p. 124) também chama de sensibilidade histórica que é respaldada na ciência, associada ao falar com, quem legitima o direito de falar $a$, faz com que a literatura de Carolina Maria de Jesus, de enfrentamento social, possibilite olhar discursivamente para uma país esquecido (o da favela), trazendo para o centro os sujeitos-resistência sem direito de valor social (recorte19), de trânsito pelos espaços da cidade e de acesso aos bens sociais, mesmo quando esses sujeitos possuem bens econômicos.

As aves (pardais) que alçam voo, representação da liberdade, da possibilidade de um meio social pautado na "solidariedade" e amizade, tão distante de reinarem no reino do sujeito-autor, esse "objeto fora de uso" que habita o "quarto de despejo", tem na "sinfonia matinal", o vislumbre de uma vida sem fome e feliz, respiro em que o poético banha um cenário de desigualdade social: de um lado, a sala de visitas (com seus lustres e cristais); do outro o quarto de despejo, a "imundíce do pátio" (habitado pelo "homem-bicho", de Manuel Bandeira) e no meio desses dois cenários o recuo, a polissemia, as "aves" e sua "sinfonia" que trazem uma paisagem outra.

Um sujeito-autor que está do lado do povo pobre (recorte 21), o do "marginal que não tem nome" (JESUS, 2014, p. 40) defendendo a causa daqueles que têm os "braços desnutridos" que resistem à fome, à dor, à aflição da miséria, não silenciando as mazelas sociais e o brado por políticos que saibam governar para/pelo povo, pois "quem paga as despezas das eleições é o povo" (JESUS, 2014, p. 128) e sabe que "o poeta enfrenta a morte quando vê o seu provo oprimido" (JESUS, 2014, p. 39).

Literatura de enfrentamento social porque reivindica direitos fundamentais, como o direito de não morrer de fome, o sujeito-autor vai em direção de um discurso lamentoso que provoca outros lamentos "morreu, mas se vivesse também morreria, de fome", quebrando 
com uma expectativa discursiva dos sentidos em curso, pois estar vivo é ter os dias contados, diferentemente de uma vida cujos dias possam ser comemorados. A morte chega devido à ausência de políticos e políticas públicas satisfatórias, que devem buscam eliminar os "quartos de despejo", garantindo mais "salas de visitas", já que "O Brasil precisa ser dirigido por uma pessoa que já passou fome. A fome também é professora” (JESUS, 2016, p. 26).

Recorte 23: 27 de maio: Que efeito surpreendente faz a comida no nosso organismo! Eu que antes de comer via o céu, as arvores, as aves tudo amarelo, depois que comi, tudo normalizou aos meus olhos.

A comida no estômago é como combustível nas máquinas. Passei a trabalhar mais depressa. Meu corpo deixou de pesar. (...) Eu tinha a impressão que eu deslizava no espaço. Comecei a sorrir como se eu estivesse presenciando um lindo espetáculo. E haverá espetáculo mais lindo do que ter o que comer? Parece que eu estava comendo pela primeira vez na minha vida (...).

É quatro horas. Eu já fiz almoço - hoje foi almoço. Tinha arroz, feijão e repolho e linguiça. Quando eu faço quatro pratos penso que sou alguém. Quando vejo meus filhos comendo arroz e feijão, o alimento que não está no alcance do favelado, fico sorrindo atôa. Como se eu estivesse assistindo um espetáculo deslumbrante. (JESUS, 2014, p. 44).

Recorte 24: 13 de maio: E assim no dia 13 de maio de 1958 eu lutava contra a escravatura atual - a fome! (p. 32).

O sujeito-autor não denuncia, enfrenta e resiste apenas às pessoas que moram na favela, mas também, à fome, que é adjetivada com uma cor, a fome é amarela. Conforme já tratamos no primeiro capítulo, Audálio Dantas tece considerações sobre o livro de Carolina Maria de Jesus, no prefácio, ressaltado que por excessiva presença, a amarela (cor da fome), saiu de cena da obra, mexendo também na pontuação e grafia de palavras que poderiam levar à incompreensão da leitura, mas, que o restante, era tudo "original”.

A nosso ver, temos uma ação violenta do jornalista em relação à escrita de Carolina, pois ao tirar de cena o adjetivo amarela, fez com que certos efeitos de sentidos fossem silenciados, pois a repetição do sujeito-autor em tratar da fome, da falta de comida e da cor da fome, amarela, traz uma marca de autoria que foi tolhida pelo editor.

No "espetáculo da vida", se para alguns sujeitos o desejo é por subir de cargo no trabalho, estudar, viajar etc, para o sujeito-favelado é ter o que comer, em que, cada vez que come é como se fosse "a primeira vez", o que faz a cor amarela se dissipar, trazendo o colorido das árvores, do céu e das aves, novamente.

O sujeito-autor no recorte 23 , ao formular que são quatro horas e que havia acabado de fazer o almoço - "hoje foi almoço" - indicia que as refeições básicas (café da manhã, almoço, café da tarde e jantar) não fazem parte do seu cotidiano; mais raro ainda é haver a presença de 
quatro tipos diferentes de alimentos, nas refeições, que é motivo de alegria e comemoração espetáculo - em que se vira "gente de verdade".

A comida possibilita que o corpo "pese menos", proporcionando o "deslizar no espaço", é o "combustível" do trabalhador que gera o "trabalho mais depressa" e, como síntese desse espetáculo que é a comida, temos a presença do sorriso, efeito discursivo do poético, em que são "quatro horas" e, diferente do ontem, o almoço já estava pronto.

Foi no dia, 13 de maio de 1888, que a Lei Áurea foi assinada pela princesa Isabel, representação de um "cheque sem fundo", pois, a liberdade diante das condições subalternas dos sujeitos-negros, escravizados, na prática, ainda hoje, não aconteceu. Isso porque de nada adiantou "libertar" os sujeitos-negros escravizados sem garantir as mínimas condições de vida (emprego e moradia, por exemplo), além do mais, depois de assinada a lei, o preconceito e os modos de funcionamento do racismo na sociedade não pararam de transmutar.

A "fome da escrita" e a "escrita da fome" fazem com que Carolina Maria de Jesus, na posição de sujeito-autor, ocupe a função-autor (ORLANDI, 2012), produzindo uma escrita que traz o novo, que desestabiliza os sentidos parafrásticos a respeito dos sujeitos da favela e suas condições materiais de existência, por exemplo, sentidos vinculados à formação discursiva segundo a qual os que moram na favela são sujeitos preguiçosos, pois é pelo discurso literário que a materialização dessas "fomes" acontece, na luta diária contra a "escravatura moderna": a da própria fome na sua polissemia de sentidos.

$\mathrm{Na}$ escrita - diária/diário - desse sujeito-autor, a repetição dos acontecimentos cotidianos não cessam, de um lado a miséria, as "fomes", o cenário do despejo; do outro, a sala de visitas, com seus lustres. Entretanto, "as convergências de novos espaços urbanos palmilhados", possibilita o furo discursivo e a polissemia, no ritmo duro do poético que é "puro fluxo, multiplicidade que se incumbe de ir além do uno, gerando microfissuras numa narrativa que vive o impasse entre o vínculo e a recriação com as relações moleculares da escrita canônica” (FERNANDEZ, 2015, p. 278), poética de resíduos que se dá na escrita dos intervalos nessa literatura cortante (ARRUDA, 2015, p. 12).

Arruda (2015) argumenta, assim como nós, que a escrita para esse sujeito-autor era uma necessidade vital, mesmo não possuindo um "teto todo seu", referência ao livro de Woolf (1998). Para a autora, temos um sujeito-autor que do vício das brigas dos vizinhos por miudezas, o alcoolismo tão presente no cenário da favela, possui outros vícios e "defeitos" os da escrita e da leitura. Para nós, trata-se do vício-resistência, pois é na posição de sujeito- 
autor que a literatura de enfrentamento social de resistência se materializa.

Uma escrita que pulsa uma "veia (discursiva) política" gritante de uma escrita "de protesto" (ARRUDA, 2015), de enfrentamento social, por meio do diário, isto é, "uma escrita quotidiana: uma série de vestígios datados" (LEJEUNE, 2008, p. 259), em que a fragmentação e a repitição fazem parte desse processo autoral discursivo, pois Carolina Maria de Jesus, na posição discursiva de autor, range com a visão de que quem escreve diários são as "pessoas instruídas", no sentido de acesso à educação formal citada por Lejeune, possibilitando a assunção da autoria e produção de um discurso literário lacinante, em que, para nós, o "corte/cortante" citado por Arruda, encontra-se na opacidade da linguagem que possibilita o enfrentamento, o protesto pela resistência, no poético.

Recorte 25: 28 de maio: (...) A vida é igual um livro. Só depois de ter lido é que sabemos o que se encerra. E nós quando estamos no fim da vida é que sabemos como a nossa vida decorreu. A minha, até aqui, tem sido preta. Preta é a minha pele. Preta é o lugar onde moro. (JESUS, 2014, p. 167).

Recorte 26: 8 de novembro: (...) Quem trabalha como eu tem que feder. (DE JESUS, 2014, p. 136).

No recorte 25, o sujeito-autor nos remete a pensar na obra Memórias Póstumas de Brás Cubas (1997), 1880, de Machado de Assis, a começar por ser uma narrativa confusa e sem linearidade, em que temos um narrador-autor defunto que decide contar as suas memórias por meio de uma seleção dos momentos mais marcantes. A narrativa é repleta de ironias, com altas doses de humor e pessimismo, também não segue nenhuma sequência cronológica e é iniciada pelo delírio e morte do próprio Brás-Cubas. Nada mais singular e autoral como a construção de um narrador-autor defunto, pois nessa condição de produção, é que "se pode saber como a vida decorreu".

No entanto, diferente de Brás Cubas que nasceu em uma família rica, o que lhe possibilitou nunca precisar "comprar o pão com o suor do seu rosto", na obra de Carolina Maria de Jesus, o sujeito-autor ao escrever sobre si, encontra-se em outra condição de existência material, em que "preta é a vida, a pele e o lugar" onde se mora.

$\mathrm{Na}$ sociedade, ainda é possível observar a palavra "preta/preto" permeada por sentidos ligados à subalternidade, por exemplo, a expressão corriqueira quando alguém diz que a sua vida está "preta", ou seja, quando o sujeito está passando por alguma situação difícil. Nesse sentido, o sujeito-autor, ao escrever sobre a sua vida, que se parece com um livro, utiliza o 
significante "preta" para representar suas experiências; todavia, se "preta" significa a vida com uma situação difícil, também pode ir em direção a outra formação discursiva, a afirmação de uma vida-corpo-pele preta que resiste.

Carolina Maria de Jesus, na posição de sujeito-autor, materializa a sua vida "preta", de mulher, mãe, negra, pobre, periférica resistindo em relação à interdição da política literária, autorizando-se a a ocupar essa posição discursiva, com a sua poética (de resíduos, lixo, excremento, das sobras) de enfrentamento social, por meio de um projeto artístico-literário que perdura o tempo todo nesse jogo do legítimo e ilegítimo, porque instaura um não-lugar na literatura brasileira.

A literatura de Carolina Maria de Jesus "fede" e todo fedor "cheira mal", exala "cheiros fortes", torna-se, muitas vezes, insuportável e repugnante, metáfora potente para pensarmos a escrita desse sujeito-autor que constrói, por meio da polissemia, novos sentidos fazendo intervir o diferente, o que incomoda, desconforta. Ao ocupar a posição de sujeito-autor resistência, a autora instala outros modos de fazer literatura, encarando a política literária e furando com uma tradição racista das letras que interdita a voz da mulher negra que "trabalha muito" para "feder", mais uma vez, o enfrentamento social resiste no/pelo poético.

Ousar colocar-se na posição de sujeito-autor sem estar autorizado é ter de "feder", isto é, "trabalhar duro", dizer, responsabilizar-se, inscrever-se, incomodar pela escrita, jogar com os sentidos, produzir rupturas possibilitando a polissemia, como o fez Carolina Maria de Jesus ao autorizar-se a ocupar essa posição tão cara, desestabilizando qualquer possibilidade de cristalização da política literária, pois o jogo entre a legitimação e a interdição de um autor e sua obra se quer no continuum da disputa, por meio do discurso polêmico (ORLANDI, 2002), em que a literatura é, sem dúvida, um ato político.

\subsection{As formas de enfrentamento social e superação pela assunção da autoria}

Não existe algo mais pesado na existência do que a própria existência. (Carolina Maria de Jesus).

No item anterior, procuramos argumentar que é pelo enfrentamento social que a escrita de Carolina Maria de Jesus se materializa, por meio de uma produção literária de resistência que, neste caso, procuramos abordar pela via do/no poético. Para isso, procuramos trazer recortes em que pudéssemos analisar a relação desse sujeito-autor com a escrita no que designamos de 
"as fomes", de modo a observarmos como esse autor faz "feder" sua literatura, isto é, sua posição política de autor.

A partir disso, analisaremos o enfrentamento social pela resistência no espaço escolar, a partir da escrita desse sujeito-autor, ponto central desta dissertação, porque uma das nossas preocupações iniciais era refletir, investigar e discutir a questão da ausência da literatura de autoria de mulheres negras nessa instituição, por acreditarmos que a escola é um dos lugares onde podemos observar o funcionamento da política literária, questionando as ausências $e$ emergências (GOMES, 2017) de temáticas ainda não inseridas no currículo e nas práticas pedagógicas dos professores, entendendo que o amanhã só se faz por meio do "que hoje se pode fazer" (FREIRE, 2018, p. 48).

Também analisaremos a resistência referente a posição de autor de Carolina Maria de Jesus na produção de uma literatura crítico-questionadora, além de cortante (ARRUDA, 2015) e de resíduos (poética) (FERNANDEZ, 2015), conforme temos procurado defender.

É com a obra, Diário de Bitita (2016) que acreditamos ter a possibilidade de observar e analisar uma escrita literária-filosófica, por meio do enfrentamento social da autorização do dizer, pois, como já apontamos, a posição discursiva de autor é política e não é autorizada para todos.

Nesse sentido, entendemos que a obra Diário de Bitita (2016), de Carolina Maria de Jesus, permite que acessemos e analisemos outras obras dessa escritora para além da sua primeira publicação, procurando contribuir, a partir do meio acadêmico, para dar uma visibilidade bibliográfica mais ampliada da escrita caroliana. Antes de mais nada, é preciso considerarmos as condições de produção em que essa obra foi publicada. Iniciamos pela visita que Carolina recebeu:

(...) recebe a visita de duas jornalistas, uma francesa, Maryvonne Lapouge, e outra brasileira, Clésia Pisa, que queriam ouvir sua história de vida para a publicação de um livro sobre mulheres brasileiras. Carolina deu não só a entrevista, mas viu nas entrevistadoras a opotunidade de publicar, no exterior, a obra pela qual tinha grande estima. Entregou a Lapouge e Pisa dois cadernos contendo o que, apenas cinco anos depois, seria publicado com o título de "Journal de Bitita", na França, pela coleção Térmoignages, da editora Métailié. Com o prefácio de Clésia Pisa, o livro, que Carolina não viu editado, e que é uma das suas melhores obras, é um diário que não é "diário", mas,sim, um depoimento franco e aberto de uma vida de muito sofrimento e pobreza quase extrema. (FARIAS, 2017, p. 342).

A obra Diário de Bitita (2016), atualmente, no Brasil, está publicada pela Editora Sesi, encontra-se na terceira reimpressão e é uma das obras de Carolina Maria de Jesus que ainda 
exige esforço para conseguir visibilidade.

Diferente da sua primeira obra, Diário de Bitita não tem marcação de data e está dividido em capítulos. Nela temos um sujeito-autor que narra, sob o ponto de vista infantil de uma criança perspicaz e atenta aos acontecimentos a sua volta. Se na primeira obra temos "a mulher exibida" que escreve, nessa, temos a "menina atrevida" que questiona os adultos até os seus últimos limites.

Iniciaremos a análise discursiva dos recortes selecionados pelo capítulo A escola, a partir do qual procuramos investigar de que modo o sujeito-autor discursiviza sobre a escola para, assim, observarmos os movimentos discursivos de resistência que culminam na produção de uma literatura de enfrentamento social desse sujeito-autor.

A legitimação dos sentidos e do dizer, assim como a interdição desse dizer e dos sentidos na literatura, efeito da política literária, está atrelada à autorização do dizer que a escola permite, ou seja, conforme já apontamos no capítulo 1, a escola tende a ser o espaço da circulação do discurso autoritário (ORLANDI, 2012) e isso provoca o cerceamento do sujeitoaluno em relação ao poder dizer, isto é, à possibilidade de constituir-se (ou não) como autor. Deste modo, determinados sentidos e dizeres são interditados, enquanto outros legitimados.

Essa questão da autorização do dizer e dos sentidos permitidos de circularem na escola nos provoca a pensarmos no que Pêcheux (2009, p. 199) designou de "bom sujeito" e "mau sujeito". Para compreendermos o que isso significa, temos de lembrar que o indivíduo é interpelado em sujeito-falante, cujos sentidos produzidos materializam-se em formações discursivas que representam, na materialidade da linguagem, as formações ideológicas que lhes são correspondentes. Deste modo, a "interpelação do indivíduo em sujeito de seu discurso se realiza pela identificação (do sujeito) com a formação discursiva que o domina" (idem, p. 198).

Apoiado em Henry, Pêcheux (ibidem, p. 198) diz que a interpelação do sujeito pressupõe um desdobramento, constitutivo de sujeito do discurso, em que um representa o "locutor", o "sujeito da enunciação", aquele que "toma posição", com "total conhecimento de causa, total responsabilidade, total liberdade etc", e o outro é o "sujeito universal". Esses desdobramentos correspondem à relação entre pré-construído ("o sempre-já aí" da interpelação ideológica e seu "sentido" sob forma universal) e a articulação ou efeito transverso (a relação do sujeito com o sentido, representada no interdiscurso que determina a dominação da forma-sujeito).

Diante disso, Pêcheux argumenta que esses desdobramentos podem assumir diferentes 
modalidades discursivas e constata duas das quais considera "evidentes":

\begin{abstract}
A primeira modalidade consiste numa superposição (um recobrimento) entre o sujeito da enunciação e o sujeito universal, de modo que a "tomada de posição" do sujeito realiza seu assujeitamento sob a forma do "livremente consentido": essa superposição caracteriza o discurso do "bom sujeito" que reflete espontaneamente o Sujeito (em outros termos: o interdiscurso determina a formação discursiva com o qual o sujeito, em seu discurso, se identifica, sendo que o sujeito sofre cegamente essa determinação, isto é, ele realiza seus efeitos em "plena liberdade". (PÊCHEUX, 2009, p. 199).
\end{abstract}

Pacífico (2002), apoiada em Pêcheux, aponta que na escola o sujeito-professor se submete ao jogo político dessa instituição, sem perceber, pois está inserido no esquecimento $\mathrm{n}^{\mathrm{o}} 1$, que faz o sujeito pensar-se na origem do dizer; todavia, o sujeito-professor reproduz o discurso de uma autoridade, geralmente, por meio do livro didático e, diante de tal reprodução (assujeitamento) do discurso do outro, acha-se na "autoridade" de fazer com o sujeito-aluno repita o mesmo discurso como se fosse dele (do professor), impondo a fôrma-leitor ao sujeitoaluno.

Nessa relação autoritária presente na escola, temos a presença do "bom sujeito", conforme entendido por Pêcheux, isto é, o sujeito-aluno reproduz o discurso do sujeitoprofessor e é discursivizado pela escola como um aluno estudioso, inteligente, educado, disciplinado, entre tantas outras adjetivações positivas perante essa instituição. O "bom sujeito" acata o que é ensinado na escola sem duvidar e executa as tarefas de modo obediente, na certeza de que se a escola mandou fazer é para ser feito.

No entanto, embora o autor não instaure discursividade como o autor original de Foucault, para Orlandi (1996) o autor produz, entretanto, um lugar de interpretação no meio dos outros, em que o sujeito só se faz autor se o que ele produzir for interpretável. A assunção da autoria ocorre pelo movimento do sujeito e dos sentidos, pois enquanto o sujeito e o sentido estão na dispersão, o texto e o autor estão na unidade. Com base nessas considerações, entendemos que, na posição discursiva de autor, Carolina Maria de Jesus, na obra, Diário de Bitita (2016), permite que observemos o funcionamento do "mau sujeito", ou seja, da segunda modalidade discursiva que Pêcheux caracteriza como sendo o discurso do "mau sujeito":

(...) discurso no qual o sujeito da enunciação "se volta" contra o sujeito universal por meio de uma "tomada de posição" que consiste, desta vez, em uma separação (distanciamento, dúvida, questionamento, contextação, revolta ...) com respeito ao que o "sujeito universal" lhe "dá a pensar": luta contra a evidência ideológica, sobre o terreno dessa evidência, evidência afetada pela negação, revertida a seu próprio 
terreno. Essa reversão apresenta traços linguísticos (...) se contra-identifica com a formação discursiva que lhe é imposta pelo "interdiscurso" como determinação exterior de sua interioridade subjetiva, o que produz as formas filosóficas e políticas do discurso-contra (...). (PÊCHEUX, 2009, p. 199-200).

Em relação ao "mau sujeito" representado na posição dos sujeitos-alunos, temos os sujeitos do enfrentamento social, no sentido de que não acatam tudo o que a escola lhes impõe, duvidam do que lhes é ensinado, naturalizado na escola, o que permite o movimento do sujeito no/pelo texto, assumindo a função-leitor questionando “(...) os efeitos de persusão e manipulação produzidos por determinados discursos que pretendem criar o efeito de universalidade do sujeito" (PACÍFICO, 2002, p. 38).

Nesse sentido, o "mau sujeito" é discursivizado na escola como um sujeito-aluno malcriado, rebelde, bagunceiro, polêmico, desobediente, indisciplinado, adjetivações negativas, em que a ideologia funciona às avessas, sobre e contra si mesma por meio do "dessaranjo e arranjo" do complexo das formações ideológicas (PÊCHEUX, 2009, p. 202).

Essas duas modalidades de Pêcheux, a do "bom sujeito" e do "mau sujeito", constituem pontos fundamentais para analisarmos os recortes abaixo, pois acreditamos que na escrita de Carolina Maria de Jesus observa-se o funcionamento de dois movimentos discursivos sobre a escola, que comprovam a argumentação desta dissertação de que se trata de uma literatura de enfrentamento social, que se dá pela escrita-resistência do sujeito.

\section{Recorte 1:}

(...)

Continuei indo à escola. Porque o comparecimento era obrigatório. Mas não me interessava pelos estudos. A minha professora insistia para eu aprender a ler. Me dirigia um olhar carinhoso. Eu achava tão difícil ler. Implorava a minha mãe para não deixar eu ir à escola.

- Eu não quero aprender a ler.

Ela ouvia-me e me dava duas chicotadas. Eu ia contra a minha vontade. Eu era preguiçosa. Quando eu faltava à aula, a professora mandava um aluno ir procurarme em casa. Quando eu chegava à escola, a dona Lonita, dizia:

A senhora é tão inteligente, procure aprender a ler. Esforce a sua cabeça.

(...) (JESUS, 2016, p. 128).

Neste recorte, observa-se que a escola para esse sujeito estava ligada à obrigação, não muito diferente do que ocorre com muitos outros sujeitos-alunos, na atualidade (ou desde sempre, talvez). O primeiro movimento discursivo que queremos destacar é em relação a esse sujeito que procura modos de não comparecer à escola, na recusa a aprender a ler, faltando às aulas e até por meio do suplício à mãe para não ir à escola. 
A "preguiça" é outra justificativa para não comparecer à escola que ressoa múltiplos sentidos: preguiça de ler; de escrever; de suportar as tarefas impostas pela escola; de não compreender as atividades, entre outros. Este movimento discursivo permite que analisemos a escola como um lugar não atrativo para certos sujeitos que procuram modos (e até comportamentos) para não estarem nesse lugar.

São "maus sujeitos" porque "tomam uma posição" lutando contra a evidência ideológica de que a escola é o lugar do aprendizado e do saber, para conhecer as letras e aprender a ler e a escrever, isto é, importante para ser alguém na vida, o sujeito não se identifica com essa formação discursiva, pois para esse sujeito a escola é o lugar do fadonho, do chato, afinal, para que serve aprender a ler e a escrever?

Os sujeitos que se filiam a esse movimento discursivo são os mais difamados, denegridos e famigerados, tanto na escola, quanto fora dela, já que são sujeitos que não se identificam com o que a sociedade discursiviza como "o bom, o certo", como por exemplo, ir à escola para ter um futuro bom elou melhor, portanto, são sujeitos que merecem ser punidos, "chicoteados", pois escapam dessa formação discursiva da escola-salvadora.

Os sujeitos desse primeiro movimento discursivo enfrentam a escola por " $n$ " motivos que dependerão sempre das condições de produção que envolvem o contexto sócio-históricoideológico, por exemplo, um sujeito-aluno que decide não prestar o vestibular, pois não se interessa em ingressar em uma universidade, mesmo sabendo que há um discurso social que enfatiza a importância do acesso ao Ensino Superior, pois é um sujeito que está filiado à outra formação discursiva, que permite a circulação de sentidos como ser alguém na vida também é possível fora da academia, aliás, o acesso à academia também não é garantia de ascensão social.

Além da voz de autoridade da mãe que obriga o sujeito a ir para a escola, como vimos no recorte, também há a da professora que não desiste desse sujeito, afinal, trata-se de alguém "inteligente" que precisa aprender a "forçar a cabeça" para que consiga de uma vez por todas aprender a ler.

Como podemos observar, "forçar a cabeça" indicia sentidos que sustentam a ideia de que cabe ao sujeito-aluno aprender o que a escola ensina, por meio do esforço e do mérito, o que fará o sujeito ser discursivizado como um "bom sujeito", isto é, inteligente e obediente, desresponsabilizando a escola em relação à aprendizagem dos seus educandos. Nesse sentido, são os "sujeitos preguiçosos", isto é, os "maus sujeitos" que não se esforçam, não se 
comprometem o suficiente e nem são os "bem-comportados" que não aprendem.

Os sujeitos que seguem o (dis)curso desse movimento, na escola, tendem a ser discursivizados, ainda mais nos conselhos de classe, como fracassados. O fracasso escolar acontece exclusivamente por causa do próprio sujeito, devido a sua falta de empenho e responsabilidade: é preguiçoso, a família é desestruturada, é falta de interesse, é inclusão, não tem mais o que se fazer, é mal-educado etc. Discursos que continuam a soar nos corredores da escola cotidianamente, principalmente, pelos sujeitos-professores, já que:

(...) a escola ainda funciona como o lugar socialmente legitimado para reprodução cultural e transmissão de conhecimento/poder, tornando-se a reprodutora da ideologia dominante, naturalizando sentidos como o da responsabilidade e culpabilização do próprio aluno pela (não) aprendizagem, ou seja, pelo fracasso ou sucesso escolar. (RIBERO, 2017, p. 114).

Essa prática de culpabilização funciona, muitas vezes, no discurso de alguns sujeitosprofessores que dizem: Eu já sou formado, é problema seu se você não quer se formar; Eu estou ganhando o meu dinheiro, se não querem aprender/estudar o problema é de vocês (sujeitos-alunos). Não cabe, aqui, nenhum julgamento de valor em relação a esses discursos, pois sabemos que a escola fracassa, a começar, pela falta de comprometimento das políticas públicas que desencadeiam em péssimas condições materiais de trabalho para esses profissionais.

Como analistas de discurso não nos compete dizer se este discurso é bom ou ruim, é correto ou incorreto, muito menos desvendar algo que esteja "por trás" das palavras, pois o que cabe ao analista é observar os movimentos discursos dos sujeitos filiados a uma formação discursiva e imaginária, os seus efeitos de sentidos no modo como a ideologia captura o sujeito fazendo-o inserir-se numa formação discursiva e não em outra, as contradições de sentidos, além de buscar interpretar o que não é dito e está silenciado no discurso (ORLANDI, 2012).

Patto (1992) pioneira no país na discussão sobre a produção do fracasso escolar, aborda que a partir da década setenta, do século XX, essa questão passou a ser estudada nos Estados Unidos, pela Teoria da Carência Cultural, como resposta política diante dos movimentos de minorias raciais devido às desigualdades que estavam expostas que, por conta da $2^{\mathrm{a}}$ Guerra Mundial, não podia mais tratar dessas desigualdades com justificativas que pudessem soar racistas. 
Por essa teoria, Patto (1992, p. 108) diz que “(...) negros e minorias latinas são portadores de deficiências físicas e psíquicas contraídas em seus ambientes de origem, principalmente em suas famílias, tidas como insuficientes nas práticas de criação dos filhos”; portanto, a culpa é sustentada no discurso de que o déficit no ambiente de pobreza prejudicaria o desenvolvimento intelectual dos sujeitos-alunos negros e latinos, na escola. Depois, em seu segundo momento, essa mesma teoria defendeu que a causa não era o ambiente deficitário, mas sim, por esses sujeitos estarem inseridos em uma cultura diferente “(...) essas pessoas fariam parte de uma subcultura muito diferente da cultura de classe média, na qual seriam baseados os programas escolares" (idem, 1992, p. 109).

Dando um "pulo no tempo", Ribeiro (2013), na sua dissertação de mestrado, de modo suscinto e pedagógico apresenta os estudos de Angelucci, Kalmus, Paparelli e Patto (2004) sobre os trabalhos desenvolvidos nos cursos de mestrado e doutorado entre 1991 e 2002. Segundo a autora, os trabalhos analisados foram desenvolvidos na cidade de São Paulo, nos cursos de Pedagogia e Psicologia tanto das universidades quanto da Fundação Carlos Chagas e apontaram as "velhas concepções" qua ainda funcionavam entre os profissionais da educação, em que, nos 71 trabalhos selecionados para análise, observou-se que os argumentos sobre o fracasso escolar ainda estavam atrelados à:

\footnotetext{
a) problema psíquico: a culpabilização das crianças e de seus pais (foco no aluno); b) problema técnico: culpabilização do professor (foco no professor); c) questão institucional: a lógica excludente da educação escolar (foco na política pública como determinante do fracasso escolar); d) questão política: cultura escolar, cultura popular e relações de poder (foco nas relações de poder estabelecidas no interior da instituição escolar, mais especificamente na violência praticada pela escola ao estruturar-se com base na cultura dominante e não reconhecer - e, portanto, desvalorizar - a cultura popular). (RIBEIRO, 2013, p. 47).
}

Apesar de longa a citação, consideramos que os argumentos sobre o fracasso escolar apresentados ainda são possíveis de serem encontrados na escola. Para Silva (2011), a relação entre educação e política é inevitável e a escola expõe em seu cotidiano, diríamos em seu funcionamento discursivo, as "fraturas" do seu fracasso. "Fraturas discursivas" que carregam o contraditório, porque ora a escola é a salvadora do homem; ora ela não serve para nada, a não ser para continuar reproduduzindo a relação desigual de poder; nesse pêndulo discursivo temos o opaco, as fissuras, as contradições, nos movimentos parafrásticos e polissêmicos de todo processo discursivo (ORLANDI, 2012).

Para esse autor, as péssimas condições de trabalho do professor fazem com que ele 
deixe o magistério e os que ficam são discursivizados por chavões: Ficou no magistério porque é ruim ou loисо; ои porque nasceu com o dom e sacrifício. Deste modo, o professor é impedido de atualizar-se, trocar ideias com outras pessoas, de pensar, de renovar, de viver como ser "consciente" da sua prática social (SILVA, 2011, p. 39), provocando o esquecimento da luta e da resistência - resistir para quê?? Nada muda na escola.

Diante desse cenário funesto, os sujeitos desse primeiro movimento discursivo, passam a fazer parte desse grupo que levam a culpa da escola fracassar, porque são sujeitos que a escola evita e marginaliza, pois ninguém consegue educar quem não quer. Nós não naturalizamos esse discurso, pois sabemos que a escola tende a "educar" pela via do discurso autoritário (ORLANDI, 2012), que só trabalha para reforçar a dominação (hooks, 2013, p. 12). Observamos o efeito da ideologia dominante na formação discursiva que permite a circulação de sentidos como: "não tem mais jeito, o que se fazer?”, sem antes, questionar: Em favor de quem eu trabalho em Educação? Qual é o meu sonho como educador? Contra o que estou trabalhando? Qual é o meu compromisso? (FREIRE, 2018, p. 40), diríamos mais, sob quais contradições minha prática como educador se dá?.

Defedemos que a resistência está justamente em buscar estratégias pedagógicas, mesmo diante desse cenário já-dado da escola, na procura de garantir, se não a todos os sujeitosalunos, pelo menos à maioria, uma educação comprometida com a transformação social, aquilo que hooks (2013, p. 17) defende, isto é, uma sala de aula como um lugar de entusiasmo, e não tédio. O entusiasmo, segundo essa autora, ocorre no esfoço coletivo criando e mantendo uma comunidade de aprendizagem, contrapondo-se à desvalorização do trabalho do professor, no "prazer de ensinar como um ato de resistência que se contrapõe ao tédio" (idem, 2013, p. 21).

As práticas pedagógicas pensadas em bell hooks partem da interação entre as pedagogias anticolonialistas, críticas e feministas, na preocupação de questionar as parcialidades que reforçam os sistemas de dominação (classe, raça, gênero). Deste modo, alinha-se à pedagogia das urgências e emergências de Gomes (2017), ambas, engajadas com a promoção de práticas antirracistas na escola.

Nesse primeiro movimento discursivo presente no espaço escolar, procuramos argumentar que os sujeitos-alunos se esforçam (ao contrário do que deseja a escola) para não estarem presentes nesse lugar, pois não se identificam com essa instituição; todavia, compreendemos que é necessário que a escola coloque em funcionamento outros discursos, 
que é preciso fazer como a professora, "buscar (metaforicamente) seus educandos", mas, não na base do castigo, e sim, a partir de um esforço, que também é coletivo, pois envolve toda a escola para a construção de um espaço que considere todos os sujeitos que nele se inserem, procurando promover uma educação comprometida com a transformação social, na busca de que os sujeitos-alunos possam, quem sabe, identificarem-se e, assim, escolherem permanecer nessa instituição, reconhecendo significados nela.

\section{Recorte 2:}

(...)

Ela percebendo que eu não me interessava pelos estudos desenhou no quadro-negro um homem com um tridente nas mãos que transpassavam uma criança e disse-me:

Dona Carolina, este é o inspetor. A criança que não aprende a ler até o fim do ano, ele espeta no garfo. No fim do ano ele vem aqui e eu vou apresenta-la a ele e pedir-lhe que dê um jeito na senhora, porque a senhora não quer estudar. Ele há de espetá-la no garfo.

Aquele desenho impressionou-me profundamente. Eu olhava o desenho e olhava o livro. Sonhava com o desenho e gritava:

- Mamãe! Olhe o inspetor! Mande o inspetor ir-se embora, que eu juro que hei de estudar. Eu vou aprender a ler. Não deixe ele espetar-me com o garfo.

(...)

O desenho permaneceu no quadro por três meses. (...).

(JESUS, 2016, p. 128).

O sujeito-aluno ao resistir à escola, depara-se com um sujeito-professor que cria modos de cerceá-lo. Neste caso, um modo de coação é pelo discurso do medo, até porque é um modo discursivo-argumentativo, muitas vezes, eficaz, quando se refere aos sujeitos desse primeiro movimento discursivo pois, caso não funcione, só resta a expulsão.

Podemos analisar que não é pelo prazer que a leitura vai ganhando sentido na vida desse sujeito, como indicia o recorte acima, visto que é pelo discurso do medo alimentado pela ameaça que esse sujeito-aluno aprende a ler. Como sabemos, todo discurso se materializa em uma formação discursiva vinculada a uma formação imaginária, o medo construído pelo imaginário se efetivou por meio da insistência "o desenho permaneceu no quadro por três meses", até o sujeito render-se (ou não).

Vejamos o próximo recorte:

\section{Recorte 3:}

(...)

Decidi estudar com assiduidade, compreendendo que devemos até agradecer quando alguém quer nos ensinar (...)

Depois percebi que já sabia ler. Que bom! Senti um grande contentamento interior. 
Lia os nomes das lojas! "Casa Brasileira, de Armond Goulart”. Não é só essa loja que é uma casa brasileira. Mas as casas, as árvores, os homens que aqui nascem, tudo pertencente ao Brasil. Percebi que os que sabem ler têm mais possibilidade de compreensão.

(...)

Vasculhei as gavetas procurando quando coisa para eu ler. A nossa casa não tinha livros. Era uma casa pobre. O livro enriquece o espírito. Uma vizinha emprestou-me um livro, o romance Escrava Isaura. Eu, que já estava farta de ouvir falar na nefasta escravidão, decidi que deveria ler tudo que mencionasse o que foi a escravidão.

(...). (JESUS, 2016, p. 129).

O efeito de sentido de gratidão no começo do recorte nos remete pensar no agradecercristão, isto é, evocam sentidos de subserviência. Outro ponto que nos chamou a atenção é a utilização da conjunção adversativa "mas" em que observamos uma marca linguística discursiva de alumbramento do poder da linguagem na vida desse sujeito-autor.

É possível perceber que o sujeito não permaneceu nesse primeiro movimento discursivo, visto que, aos poucos, por meio do processo de "obrigação", interpelado pela figura da mãe, da professora, dos coleguinhas da sala que iam até a sua casa, esse sujeito filia-se ao discurso pedagógico e aprende a ler.

A aquisição da língua escrita, para nós, é um processo discursivo; portanto, não se reduz a uma instrução formal, pertencente ao âmbito individual, concebida como aprendizagem de habilidades para leitura, escrita e as chamadas práticas de linguagem. Tampouco a leitura se resume à decodificação de textos, como propõem t antos livros didáticos, especialmente, aqueles destinados aos anos iniciais de alfabetização. É a leitura de mundo que deve preceder a leitura do texto (FREIRE, 2018). Entendemos que quando lemos participamos do processo sócio-histórico de produção dos sentidos e o fazemos a partir de um lugar social e com uma direção histórica determinada (ORLANDI, 2012).

No caso do recorte, percebemos que o sujeito constrói sentidos para o que lê - o nomes das lojas - em que, o sujeito, por meio do interdiscurso recortado pela memória discursiva, expõe-se aos múltiplos sentidos de "Casa Brasileira" - a da loja, a do lar, a do país - a leitura como "possibilidade de compreensão" do que está no mundo, isto é, de acesso aos enunciados expostos na sociedade. Sabendo que o texto sempre apresenta várias possibilidades de leitura, o sujeito, com a sua história de leitura compreende os enunciados dentro de algumas possibilidades de sentidos e não outras (PACÍFICO, 2002).

Uma vez identificado e "tomado" pelo prazer da leitura, o sujeito tende a buscar o acesso ao arquivo (PÊCHEUX, 2010), no caso do sujeito-autor é pelo intermédio dos empréstimos de livros da vizinha, e não por meio de livros emprestados da escola que esse acesso se dá, o que 
indicia mais uma contradição do discurso pedagógico. E a cada leitura, mais o sujeito deseja saber e "decidi que deveria ler tudo que mencionasse a escravidão".

Analisemos o próximo recorte:

\section{Recorte 4:}

(...)

A aula era mista. A minha professora dizia no fim da aula:

Eu quero falar com meus alunos pretos, é assunto muito importante. Os brancos saíam, e nós ficávamos. Ela dizia:

Estou notando que os meus alunos brancos são mais estudiosos do que os meus alunos pretos. Os brancos não erram quando escrevem. Lavam as mãos quando vão pegar os livros. Os desenhos então, que primor! Eles capricham e ganham cem todos os dias.

Agora eu compreendo o que é ganhar cem (grifo nosso). É quando a lição é bemfeita. Quando saímos da escola, estávamos furiosos e pensando: os brancos... não hão de saber mais do que nós!

Passados uns dias, ela pedia aos alunos brancos para ficarem na aula. Dizia-lhes que os alunos pretos eram os mais esforçados (...)

Os alunos brancos saíam da aula revoltados.

Cada um ia comentando:

- $\quad$ Imagine só, o negro querer ser maior do que eu. Maioral tem que ser eu, que sou branco. Esses negros vão me pegar!

Agindo assim (grifo nosso), ela não tinha problemas com as lições de casa.

(...) (JESUS, 2016, p. 130).

Neste recorte temos o segundo movimento discursivo, em que o sujeito-aluno, impulsionado pelo sujeito-professor, que provoca uma prática racista ao separar os brancos dos pretos e vice-versa, começa a desconfiar da capacidade dos "brancos" serem mais inteligentes que os "negros". O sujeito-aluno começa a observar o que faz os "brancos" alcançarem esse patamar privilegiado e positivo no discurso da professora: eles "lavam as mãos antes de pegar nos livros", procuram "errar menos nas lições quando escrevem" e produzirem "desenhos caprichosos e primorosos". Pelo jogo das formações imaginárias, o sujeito-aluno compreende que bastava entrar nesse jogo político-discursivo para ganhar também "cem todos os dias".

Em nenhum momento o sujeito enuncia o prazer de executar essas atividades, como fez ao comentar sobre as leituras, a "descoberta" dos nomes das lojas, isto é, a leitura de "mundo" significativa; portanto, ganhar "cem" da escola não indica que esse sujeito executa as atividades da escola de forma prazerosa. Interpretamos que o sujeito joga o jogo político da escola a fim de sobreviver, o que pode ser compravado pelo enunciado "Agora compreendo o que é ganhar cem. E quando a lição é "bem-feita", a nosso ver, o sujeito- 
aluno ocupa, dissimulando, a posição do "bom sujeito".

Isso é bem diferente do "bom sujeito" que aceita sem questionamento o modo como a escola ensina, por exemplo, como produzir uma redação nota 1000, pois, muitos sujeitosescolares não compreendem as condições de produção mais amplas, isto é, sócio-históricoideológicas, que estão em jogo nas famosas cinco competências da redação dissertativaargumentativa do Enem.

Os sujeitos-alunos brancos também impulsionados pelo sujeito-professor, enfurecem por não estarem atingindo o que a escola espera deles, deixando com que os negros "passem à frente", afinal, o sujeito capturado pela ideologia dominante, nesse caso, a que sustenta o discurso racista, não consegue deslocar-se dos sentidos parafrásticos - branco é superior ao negro - e reproduz o racismo por meio da revolta "Esses negros vão me pagar".

Temos uma formação discursiva sustentada por uma formação ideológica racista que recai na formação imaginária "Quem é ele para ser melhor do que eu?”; no entanto, esse sujeito não se dá conta, devido aos dois esquecimentos, de que o sujeito-negro passou a jogar o jogo político das relações hierarquizadas pela escola, pois, "agindo assim”, esse sujeito também não teria "problemas com as lições de casa", o que consideramos como um gesto de "manhas".

Esse segundo movimento discurso designaremos de práticas discursivas manhosas, a partir de Freire (2018, p. 36) quando em diálogo com os missionários que atuavam junto às comunidades indígenas de Mato Grosso, durante a $8^{\mathrm{a}}$ Assembleia do CIMI (Conselho Indigenista Missionário), Regional MT, realizada em Cuiabá, de 16 a 20 de junho de 1982, argumenta que ao observar e tentar compreender o comportamento das classes sociais e dos sujeitos dominados, pobres, espoliadas diz que:

\footnotetext{
Há algum tempo eu venho observando o luxo e o comportamento superficial dos grupos dominados; eu andei observando nesse comportamento uma série de posturas que eu andei chamando de manhas dos dominados, manhas históricas. As manhas se explicitam na linguagem, na cor, na atitude, e na própria reação ao frio. Se não fossem as manhas, os oprimidos se acabariam, não dava para sobreviver, A violência dos exploradores é tal que, se não fossem as manhas, não haveria como aguentar o poder e a negação que se encontram no país. (FREIRE, 2018, p. 36).
}

Freire discute a negação dos sujeitos-indígenas no país, com o que fazemos analogia em relação aos sujeitos-negros, pertencentes ao grupo dos sujeitos-oprimidos, pois, conforme aponta o recorte que estamos analisando, a formulação você é (vale) menos do que eu, no caso, sustentado pelo discurso racista do sujeito-branco e vinculado às formações imaginárias, 
materializa o discurso discriminatório e, por vezes, preconceituoso contra os sujeitos-negros oprimidos.

Para dar um exemplo sobre o funcionamento da "manha", Freire apresenta a seguinte situação: um sujeito que vive na zona urbana privilegiada bebe água na zona rural, ou periférica da cidade, ou seja, essa água vem do rio e não passou por um tratamento de água e, muito menos, por um purificador. O sujeito, então, tem o seu organismo "adaptado", de modo que essa "manha" é "orgânica, fisiológica, biológica", sem a qual o oprimido (e também, por vezes, o opressor, nessa situação) desapareceria.

No entanto, continua argumentando Freire, a "manha" também passa pela linguagem (ponto que nos interessa), em que, nessa mesma situação chega o extensionista rural, o missionário e o sanitarista, todos proferem seus discursos para os sujeitos-camponeses; contudo, segundo esse educador, existe a História, o que na teoria discursiva consideramos ser as condições de produção sócio-histórico-ideológicos, que faz com que os sujeitoscamponeses, filiados à outra formação discursiva, continuem fazendo exatamente o que gostariam de fazer, dando a impressão que estão satisfeitos e contam com o discurso alheio, mas não, sendo até "possível que o camponês faça o que eles querem: em determinadas situações, o camponês não tem outra opção senão fazer, ele também já sabe” (FREIRE, 2018, p. 37) .

Segundo a teoria discursiva, as "manhas" poderiam ser compreendidas, neste trabalho, como as práticas discursivas dos sujeitos que fogem do esperado. Trazemos essa noção para a teoria discursiva sabendo, no entanto, que teremos de dar outro teor teórico para refletirmos sobre o que estamos entendendo como sendo o segundo movimento discursivo do sujeito, que designamos por práticas discursivas manhosas. Essa prática discursiva pode ser observada pela materialidade da linguagem e seus indícios, quando um sujeito joga o jogo político, aparentemente, na posição de "bom sujeito"; todavia, é uma "manha", uma possibilidade dada pela opacidade da linguagem, em que esse sujeito dissimula filiar-se a determinada região do sentido para "sobreviver". Sabemos que essa tomada de posição não se dá de forma consciente, uma vez que o sujeito é atravessado pela ideologia; porém, pelo jogo das formações imaginárias entendemos que é possível ao sujeito embrenhar-se em práticas discursivas manhosas.

No caso do recorte que estamos analisando, o sujeito ao fazer uso da prática discursiva manhosa, por ter interpretado o funcionamento político das relações de poder na escola, 
dissimula "Agora eu compreendo o que é ganhar cem. É quando a lição é bem-feita", pois, "Agindo assim, ela não tinha problemas com as lições de casa", esse sujeito "conquista" o seu espaço na escola e passa a ser discursivizado pelo sujeito-professor de outro modo - "pretos esforçados, estudiosos, capacitados" - ocupando o lugar de "bom sujeito", e isso é um gesto discursivo de "manha", porque incomoda os sujeitos-brancos.

Se no caso do sujeito-professor a prática pedagógica, distante de uma prática antirracista, ao inferiorizar, ora os sujeitos-negros; ora os sujeitos-brancos, como estratégia argumentativa para convencer os sujeitos-alunos a ocuparem a posição de "bons sujeitos", isto é, que estudam, por outro, o sujeito-negro inferiorizado e indignado com os sujeitos-brancos "não hão de saber mais do que nós!", também como estratégia enfrenta "manhosamente" as coerções da escola, jogando o jogo da escola "agindo assim”, assim como a escola quer.

E sobreviver, mesmo que pela "manha", a fim de não ser eliminado, ou, fazer parte dos que "fracassaram", como os sujeitos do primeiro movimento discurso, também não seria um modo de enfrentamento social? A nosso ver, sim, não sem contradições.

Nesses dois movimentos discursivos que apresentamos, o sujeito tende a ocupar mais a paráfrase, do que a polissemia. No primeiro movimento discursivo o sujeito-aluno enfrenta a escola, no entanto, ao fazer isso acaba eliminado por ela, o que consideramos como a repetição do mesmo, produção da paráfrase - do fracasso escolar - por conta das condições de produção que já apresentamos.

No segundo movimento discursivo, por sua vez, o sujeito-aluno, pela prática discursiva manhosa, joga o jogo político da escola a fim de sobreviver nessa instituição; todavia, também está inserido, a nosso ver, no plano da paráfrase, porque ao ter que jogar esse jogo político da escola retorna à repetição do sentido legitimado pelas instituições sociais (PACÍFICO, 2002, p. 26).

O leitor deste trabalho pode então perguntar-se: se tudo está para a paráfrase, em que ponto estaria a possibilidade do novo, da ruptura, da polissemia? A nosso ver, está justamente na autoria de Carolina Maria de Jesus que, na posição discursiva de autor, não deixou silenciado em sua obra a questão da escola e desses movimentos discursivos.

Compreendemos que Carolina Maria de Jesus, na posição de autor, instala uma discursividade que não silencia os movimentos discursivos dos sujeitos-alunos na escola, tanto o enfrentamento do sujeito no primeiro movimento discursivo, quanto a prática discursiva manhosa, no segundo movimento discursivo, que só foram possíveis de serem 
observados e analisados porque esse sujeito-autor, pela materialidade linguística, produziu uma literatura de enfrentamento social, em que os gestos de autoria podem ser vistos também como gestos de resistência, pois ao acessarmos os escritos dessa autora, sentidos são colocados em cena, sentidos esses que fazem a sua literatura "feder", isto é, incomodar.

Todas a discussão desenvolvida até aqui nos permite "amarrar" com a questão da legitimação e interdição das obras literárias, efeito produzido pela política literária. Isso porque, conforme procuramos defender, o modo como se concebe o que é literatura traz implicações para a concepção de sujeito-autor, discussão necessária quando procuramos investigar como um discurso sobre o que é literatura pode desencadear na legitimação ou interdição de um autor e sua obra.

Nesse caso, Diário de Bitita (2016), possibilita outros enfrentamentos sociais embatidos pela escrita de Carolina Maria de Jesus, no entanto, ainda é uma obra pouco difundida/estudada nos pequenos círculos acadêmicos sobre literatura afro-brasileira, em que grande parte dos trabalhos acadêmicos sobre a literatura da autora tiveram a atenção voltada para o primeiro livro. Deste modo, defendemos que os centros acadêmicos devem trabalhar não só com outras obras de Carolina, mas também, de outras mulheres negras, de modo a garantir a circulação e a leitura delas.

Ainda sobre a obra Diário de Bitita, de Carolina Maria de Jesus, também analisamos um último movimento discursivo de enfrentamento social, por meio das marcas de autoria desse sujeito-autor. Dizemos último movimento sabendo que, pela teoria com a qual trabalhamos (AD), faz parte da função-autor o ponto final (ORLANDI, 1996b), (PACÍFICO, 2002), mesmo sabendo que isso é um efeito discursivo ilusório (PÊCHEUX, 2009), até porque, os sentidos trabalhados nesta dissertação sempre poderão vir a ser outros, mesmos por quem os escreveu, porque as condições de produção também serão outras.

Diante disso, defenderemos que a literatura de Carolina Maria de Jesus foi produzida por meio de uma escrita-questionadora, cortante (ARRUDA, 2015), sua poética de resíduos (FERNANDEZ, 2015), conforme temos procurado defender. Acrescentamos, então, que com a obra Diário de Bitita (2016), temos a possibilidade de observar e analisar uma escrita literária-filosófica, que o tempo todo incomoda e "fede", porque, sobretudo, autoriza-se a dizer onde não foi "chamada/convidada/autorizada", por isso mesmo, gesto de resistência. Vejamos nos recortes: 
(...) Cheguei à conclusão de que não necessitamos perguntar nada a ninguém. Com o decorrer do tempo vamos tomando conhecimento de tudo.

Quando minha mãe falava, eu me apoiava nela para ouvi-la. Um dia, a minha mãe repreendeu-me e disse-me:

- Eu não gosto de você!

Respondi-lhe:

- Se estou no mundo é por intermédio da senhora. Se não tivesse dado confiança ao meu pai, eu não estaria aqui.

Minha mãe sorriu e disse:

- Que menina inteligente. E está com quatro anos.

Minha tia Claudemira comentou:

- Ela é mal educada.

Minha mãe defendia-me, dizendo que eu tinha dito a verdade.

- Ela precisa apanhar! Você não sabe criar filhos.

(...)

- Bate, Cota! Bate nessa negrinha! Ela está com quatro anos, mas o cipó se torce enquanto é novo.

(...)

(JESUS, 2016, p. 14).

Neste recorte temos a materialização da escrita-indagadora de Carolina Maria de Jesus, em que as reflexões sobre o mundo e o seu funcionamento fazem parte do enredo da literatura-filosófica dessa autora, diante de um mundo em que as respostas às perguntas vem com o tempo, deste modo, vai se "tomando conhecimento de tudo".

É Pêcheux (2014, p. 73) quem nos apresenta o termo processo de produção, dizendo que trata-se do "conjunto de mecanismos formais que produzem um discurso de tipo dado em “circunstâncias" dadas”. Essas circunstâncias são as condições de produção e seu processo de produção, deste modo, "um discurso é sempre pronunciado a partir de condições de produção dadas" (idem, 2014, p. 76), podendo ser um ato político direto ou um gesto vazio como modo de "dar o troco", o que também indica que é uma ação política.

É a partir dessas considerações que Pêcheux (2014, p. 81) argumenta que trabalhar a linguagem não se trata de pensar em comunicação (emissor, receptor, mensagem, decodificação) e, a partir dessa ruptura ele instaura a teoria discursiva, que tem como objeto de estudo o discurso. Esse autor desloca o conceito da teoria da comunicação de uma transformação de informação entre $A$ e $B$, para o conceito, na teoria discursiva, de um "efeito de sentidos" entre os pontos $A e B$.

Esses pontos $A$ e $B$ designam lugares determinados que são representados nos processos discursivos em que são colocados em jogo, sendo assim:

(...) o que funciona nos processos discursivos é uma série de formações imaginárias que designam o lugar que $A$ e $B$ se atribuem cada um a si e ao outro, a imagem que 
eles se fazem de seu próprio lugar e do lugar do outro. Se assim ocorre, existem nos mecanismos de qualquer formação social regras de projeção, que estabelecem as relações entre as situações (objetivamente definidas) e posições (representações dessas situações) (PÊCHEUX, 2016, p 82).

As formações imaginárias são importantes porque, como vimos argumentando, elas ancoram a produção dos sentidos. Assim, podemos observar no recorte uma interlocução entre a mãe, a filha e a tia, em que a mãe, ao aviltar a filha "Eu não gosto de você!", nesse mesmo movimento discursivo, a filha também avilta a mãe, tocando em "feridas discursivas" que provocam desconforto, no que a mãe, "sem palavras", interpreta o aviltamento como "inteligência", afinal, a resposta da filha, argumentativamente, silencia a mãe.

No entanto, nesse jogo das formações imaginárias, temos a tia que projeta a imagem de “quem é ela para falar assim com a mãe?" e interpreta a resposta da menina como sendo "mal educada", colocando-se na posição discursiva da mãe (sujeito-adulto que merece "respeito"); logo, a tia argumenta que a filha precisa "apanhar", pois o "cipó se torce enquanto é novo", isto é, o efeito de sentido é outro para esse sujeito-tia.

É por isso que consideramos a escrita de Carolina Maria de Jesus ferina, crítica, questionadora, porque está o tempo todo nessa não autorização do dizer, seja pelos críticos literários, seja pela tia, seja pelos moradores da favela.

\section{Recorte 6:}

(...)

Um dia perguntei a minha mãe:

- Mamãe, eu sou gente ou bicho?

- Você é gente, minha filha!

- O que é ser gente?

(...)

(JESUS, 2016, p. 15)

\section{Recorte 7:}

(...)

Mamãe! Mamãe ... fala-me do mundo. O que quer dizer mundo?

Ela me deu dois tapas, saí correndo e chorando.

Minha tia Claudemira disse:

- Você precisa dar um jeito nessa neguinha. Ela vai te deixar louca.

(JESUS, 2016, p. 28).

\section{Recorte 8:}

(...)

Perguntei-me à minha mãe:

- Por que o mundo é tão confuso?

Respondeu-me:

- O mundo é uma casa que pertence a diversos donos, se um varre, vem o outro e 
suja-a.

(...)

(JESUS, 2016, p. 54).

\section{Recorte 9:}

(...)

- Sabe, mamãe, eu não estou gostando deste mundo. A senhora quer me pôr onde eu estava?

Ela explicou que para sair deste mundo era preciso morrer.

- Ah, de morrer eu tenho medo.

(...)

(JESUS, 2016, p. 93).

\section{Recorte 10}

(...)

Fui procurar a minha mãe.

- A senhora pode me dar o endereço de Deus?

Ela estava nervosa, deu-me uns tapas. Fiquei horrorizada: "Será que a minha mãe não vê a luta dos negros? Só eu?". Se ela me desse o endereço de Deus, eu ia falarlhe. Para ele dar um mundo só para os negros.

(...)

(JESUS, 2016, p. 95-96).

\section{Recorte 11}

(...) Minha mãe dizia que o mundo era assim mesmo.

Fiquei furiosa.

- Ah, comigo o mundo vai modificar-se. Não gosto do mundo como ele é.

Minha mãe corria e perguntava:

- O que é que você vai fazer do mundo?

- Não quero gente grande no mundo. São os grandes que são maus. As crianças brincam juntas, para elas não existe cor. Não falam em guerras, não fazem cadeias para prender ninguém.

Eu não gosto dos grandes. Os grandes têm coragem de enfiar uma faca no outro. Outro dia, um espinho entrou no meu pé e doeu tanto! E se fosse uma faca? O tio Cirineu me ouvia e disse:

- Essa negrinha vai longe.

(JESUS, 2016, p. 110).

Decidimos deixar esses seis recortes juntos porque, em nosso entendimento, todos eles representam a escrita-indagadora de um sujeito-autor produtor de uma literatura-filosófica. Por escrita-indagadora deve-se compreender a materialização da língua por meio de um discurso repleto de interrogações, isto é, questionamentos existenciais acerca do humano, desencadeadores de uma literatura-filosófica, em que a sua base é a produção da dúvida, do não-sentido fazendo sentido, ou o contrário; portanto, trata de uma escrita que "fede", esbarrada na autorização do não dizer, pela resistência do dizer.

O sujeito-autor materializa na obra literária diversos questionamentos: "Mamãe, eu sou gente?", "Mamãe, o que quer dizer o mundo"?, "Por que o mundo é tão confuso"?, "Quer me 
pôr onde eu estava?", "Pode me dar o endereço de Deus?", "O que é que você vai fazer do mundo?". Perguntas essas que causam desconforto porque não, necessariamente, exigem/existem respostas "certas", representação do inefável da linguagem, no não-sentido fazendo sentido e vice versa.

Mais uma vez a questão da (des)autorização do dizer está presente nos recortes. No recorte 7, os questionamentos da filha fazem a mãe "perder" a paciência, que utiliza da violência física no intuito de "calar" a menina. O que é que se cala? A nosso ver, não somente a tentativa de silenciar os questionamentos da filha, mas também tenta-se calar/controlar o "borbulhamento" que esses sentidos provocam, estranham, inquietam. Dizer o que é o mundo é tão violento quanto a violência física.

A tia, que também participa do processo discursivo, aprova a ação da violência física da mãe, a partir de uma formação imaginária que desconsidera o sujeito-criança a dizer, ainda mais, quando o que é dito são perguntas que deixam qualquer um "louco". Utiliza-se da violência física porque os "loucos" não podem existir, pois desestruturam o "semanticamente estabilizado" (PÊCHEUX, 2009), corrompem, fazem pensar, e pensar é um ato político transformador, prazeroso, mas também e, talvez, sobretudo, doloroso. A dor física deve "apagar" a "dor" da existência, os "loucos" devassam o mundo.

Se o mundo é tão confuso (recorte 8) é porque a culpa é de alguém. É que na "casa" do mundo existem os "diversos donos" que "varrem" e "sujam-na", representação metafórica da literatura de Carolina Maria de Jesus que, por meio da posição discursiva de autor, "varre", organiza - coesão e coerência - a sua escrita-indagadora, por vezes, é por meio da "sujeira", da poética de resíduos (FERNANDEZ, 2015), dos restos, do lixo, do papel/papelão, do "catar palavras" que a a sua escrita se dá, nesse movimento discursivo do "varrer", "sujar", tão necessário para o sujeito-autor de literatura.

Ocupar a posição discursiva de autor implica a responsabilização do dizer pela construção de textos com sentidos coerentes e isso é um processo trabalhoso e complexo, porque nem sempre é possível "pôr onde estava" (recorte 9) o sentido, porque o sentido sempre pode ser outro, escapa. No entanto, para ser autor é preciso transformar algo que já existe, acrescentar o novo (polissemia), como se “ (...) a "matéria" para a construção do texto fosse uma massa de modelar que já tem uma existência (o já-lá, o interdiscurso), mas cada sujeito pode dar uma nova forma para ela (o intradiscurso) (PACÍFICO, 2002, p. 107), o que é possível quando se trabalha na tensão entre paráfrase (a massa) e polissemia (as novas formas que podem ser 
criadas).

Não gostar do mundo é um direito e a única possibilidade de "escapar" dele é pela escrita (arte, literatura, imaginação), pois não é possível "pôr para dentro" (recorte 9) quando o exterior também é constitutivo, como é o caso da linguagem e do sujeito. Nesse sentido, o modo mais radical de "sair" do mundo é pela morte, certeza do humano e mistério, produtora do "medo"; deste modo, não há escolha para o sujeito, o jeito é seguir inquietamente, desassossegadamente, gostando ou não do mundo.

É interessante observar o movimento discursivo contraditório do sujeito-autor em que, ora a mãe defende a filha e a compreende; ora utiliza da violência física. Entretanto, essa contradição é pertinente porque está ligada à discussão da autorização do dizer e das condições de produção, em razão da escrita-indagadora do sujeito-autor que também, ora é "suportável”; ora não o é, “A senhora pode me dar o endereço de Deus?" (recorte 10), pergunta dos "loucos", pecadora, porque leva o nome de Deus em "vão".

A mãe, por estar em outra formação discursiva, não compreende a pergunta da filha, violenta-a fisicamente, porque a pergunta que recebe não deve ser feita; contudo, a filha atravessada pela literatura-filosófica por outra formação discursiva, autoriza-se a dizer, a perguntar, a materializar suas "ânsias existenciais", horrizam e deixam nervosa a mãe, nesse mundo injusto em que a luta do negro se dá.

Para a mãe o mundo é como é (recorte 11) e isso enfurece a filha que resiste a esse discurso da mãe, pois não gosta do mundo como ele é e, por isso, é preciso modificá-lo. A mãe ironicamente pergunta "O que é que você vai fazer do mundo?", então, a filha argumenta que não quer um mundo de "gente grande", causadores das guerras, do racismo, da construção de prisões, que enfiam a "faca no outro", situação essa sentida pela filha por meio do "espinho no pé".

Os argumentos na resposta da filha ressoam sentidos de enfrentamento social pelo viés da resistência, pois parte da tese que o mundo so é o que é porque existem pessoas como a mãe, desacreditadas na possibilidade da mudança/transformação social. A mãe também é representação das "gentes grandes" que "esfaqueiam" a esperança com a sua incredulidade e ironia perante as "gentes pequenas".

O tio, participante da interlocução, é afetado pelo discurso da filha e a enaltece "ela vai longe", o que associamos com a escrita-indagadora de Carolina Maria de Jesus, que é laboriosa e espinhosa, por isso mesmo potente, desencadeadora de uma literatura-filosófica 
que transgride a autorização do dizer, porque é preciso dizer mesmo impedido de dizer, lembrando que o silêncio também significa (ORLANDI, 1997). Ser "gente" ou "bicho" (recorte 6), eis a questão, nesse caso, importa a pergunta e não a resposta.

\section{Recorte 12}

(...)

Lembrei-me da irmã Augusta:

- O mundo é mesmo um teatro de aguras.

(...)

(JESUS, 2016, p. 166).

\section{Recorte 13}

(...)

A segunda casa onde bati e pedi esmola, a dona da casa disse:

- Vai trabalhar, vagabunda!

Fiquei sem ação. Eu que tenho um espírito de luta, de arrojo inabalável, que sou forte nas resoluções. Chorei.

(...)

Fui andando resignada. Era o início da minha vida, e o destino estava apresentandome às pessoas desunamas que transitam por este mundo. Os tipos que são imortais, destituídos das belas qualidades, e com péssimas formações morais.

(...)

Eu tenho que ser firme nas minhas resoluções.

(...)

Eu estava habituada a lidar com pessoas rudes como o cacto.

(...)

Eu tinha a impressão que não era ninguém neste mundo. E eu pretendia ser alguém, e para ser alguém é necessário empregar o seu tempo exercendo qualquer profissão. (...)

(JESUS, 2016, 168-174).

\section{Recorte 14}

\section{(...)}

Eu não tinha casa. Que luta!

(...)

(JESUS, 2016, p. 187).

\section{Recorte 15}

(...) Eu já estava cansada daquela vida de andarilha. Eu tinha a impressão de ser uma moeda circulante.

(...)

(JESUS, 2016, p. 190).

$\mathrm{Na}$ agura do teatro da vida (recorte 12) cansado de ser andarilha e moeda circulante (recorte 15) e também de não ter casa (recorte 14), ufa, que luta é a vida! O sujeito-autor materializa sentidos que ressoam enfrentamento social diante de uma existência em que se é 
preciso ser seu próprio lar.

Podemos interpretar a questão da publicação da primeira obra de Carolina Maria de Jesus, conforme abordamos no primeiro capítulo, em relação a essa existência "andarilha", "sem casa", isto é, uma autora que até hoje perturba e encanta devido ao rebuliço que causou na história da literatura brasileira, cavando um lugar, a partir do não-lugar, nas letras. E também em relação à sua ascensão econômica frágil de "moeda circulante" no mercado editorial brasileiro.

Carolina Maria de Jesus, conforme já abordamos, também, no capítulo 1, "bateu em muitas portas" à procura de trabalho e de meios para que suas obras pudessem ser publicizadas, por isso, enfrentamento social. Apesar disso, foi discursivizada como "vagabunda" (recorte 13), sempre foi insultada. Diante das atribulações, resignações e miséria do mundo - o choro - respiro, poesia-dura, descanso, porque depois a luta continuava, no “arrojo inabalável e forte nas resoluções" desse sujeito-autor.

As pessoas desumanas, os que se veem como "imortais", com "péssimas condições morais destituídos de qualidades" era preciso ser "firme" para lidar com esses "cactos", imagem que associamos com a literatura de autoria de mulheres negras que, na "impressão de não serem ninguém no mundo", colocam-se a escrever e a produzir literatura, nessa árdua profissão de escritor, a fim de ser "alguém na vida".

\section{Recorte 16}

Que alguém sempre é autoridade de alguém.

(...)

Rezava agradecendo a Deus e pedindo-lhe proteção. Quem sabe ia conseguir meios para comprar uma casinha e viver o resto de meus dias com tranquilidade... (JESUS, 2016, 200-206).

Defendemos que a escrita-indagadora de Carolina Maria de Jesus provoca no leitor múltiplos sentidos que perfazem o seu projeto literário como escritora, sentidos que culminam em uma literatura-filosófica que trabalha o interdiscurso no intradiscurso, recheada de questionamentos que enfrenta a autoridade do dizer e as condições de produção, materializada na escrita de uma improvável autora/autoria.

A literatura de Carolina Maria de Jesus é de enfrentamento social porque resiste por meio do poético, ponto de respiro e salvação, assim como pelo não silenciamento de movimentos discursivos sobre a escola, instituição possibilitadora (ou não) de transformação social, por fim, pela escrita-indagadora que ousa dizer e perguntar: quem sabe? 
Afinal, quem sabe se a literatura de autoria de mulheres negras revolucionará o campo minado dos clássicos da literatura que, por meio da política literária, range com a fixidez do cânone, deixando a ferida do racismo estrutural aberta/exposta, ousando-se a dizer, movimentando o pêndulo da legitimação e interdição, jogo político desse picadeiro universo das letras, possibilitando outras geografias do fazer literário. 


\title{
CONCLUSÕES
}

\begin{abstract}
"Não decoro texto de que não gosto, não/ É muito triste, é muito violento/ Uma pessoa negra, escritora, pode passar a vida sem ninguém desconfiar/ E ainda achar que aquilo não é para ela/ É um assunto muito gravel Se você observar, tem uma cerca em todos os lugares/ De mais prestígio onde o negro não pode entrar/ Então uso a arte, porque é a educação não formal mais poderosa" (Elisa Lucinda).
\end{abstract}

Figura 17 - Cinderela negra: a saga de Carolina Maria de Jesus

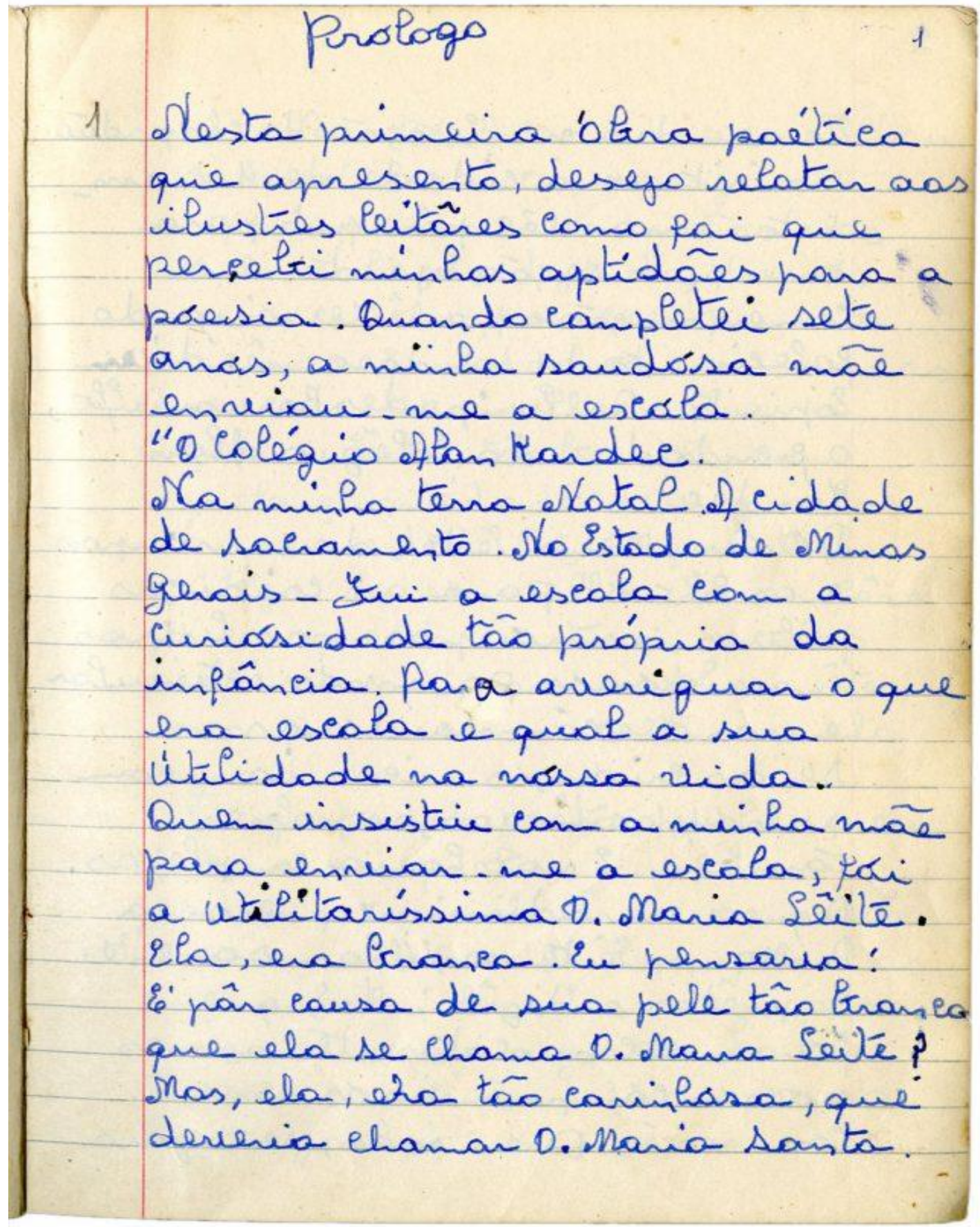

Fonte: LEVINE, R, M; MEIHY, J, C, S, B. (1995) 
A partir da teoria da Análise de Discurso, a conclusão de um texto é sempre um efeito ilusório (começo, meio e fim) necessário para a garantia da autoria do sujeito-autor pesquisador. E o ponto final é uma das partes mais difícies, porque provoca uma sensação de que se podia ter dito mais. No nosso caso, certamente, muito mais poderia ter sido investigado, refletido, observado, dito, sobre a literatura de autoria de mulheres negras. Ainda bem, pois indica movimento. E a trajetória de um pesquisador não é isso?

Ao procurarmos investigar o modo como Carolina Maria de Jesus, na posição de sujeitoautor, relaciona-se com a escrita e por meio dela constitui-se, pudemos analisar e observar que a sua "fome da escrita" e a "escrita da fome" é uma das temáticas centrais de suas obras, mesmo quando a discussão é sobre a escola que também tem "fomes" de um espaço de aprendizagem que desloque os sujeitos-alunos da fôrma-leitor para a função-leitor (PACÍFICO, 2002), em prol de uma educação comprometida com a transformação social (hooks, 2013), por meio de uma pedagogia das ausências e emergências (GOMES, 2017).

As "fomes", como metáfora para pensarmos a constituição do sujeito-autor na/pela escrita, possibilitaram designarmos a literatura desse sujeito como enfrentamento social que marca as suas denúncias sociais, a saber: a "fome de escrita", de acesso à educação, cultura, saúde, visto que é pela materialidade escrita que se tem contato com o discurso de denúncia social desse autor que relata, em seus diários, os enfrentamentos pelos quais passa em sua vida de mulher, negra, mãe, periférica, catadora de papelão e escritora.

A escritora ao narrar a sua escrita da fome em - Quarto de Despejo: Diário de uma Favelada (2014) - publicada em 1960 - traz à tona as vidas das pessoas miseráveis que vivem em locais insalubres e esquecidos pelas políticas públicas. Lugar da fome - a Amarela - que nega aos sujeitos-favelados as garantias básicas de dignidade humana, afinal, a Amarela é personagem principal e central e os sujeitos-favelados coadjuvantes que lutam contra ela.

Carolina Maria de Jesus foi uma mulher negra, mãe, pobre, periférica que, ao assumir a posição de sujeito-autor, produziu obras e discursos que dão voz aos marginalizados, aos que são silenciados e interditados pela sociedade.

É exercendo o seu papel social e político de autora que Carolina Maria de Jesus rompe com uma formação imaginária de sujeito-autor ideal (branco, classe média, com alto grau de escolaridade, intelectual), pois é uma mulher, negra, periférica, que escreve, e isso ainda é visto como aviltamento, por causa de um modo de organização social que tem o racismo em seu cerne, fazendo com que sujeitos-negros sejam reconhecidos no plano da objetificação e 
não como sujeitos de escolhas, de direitos e dizeres.

Por isso que é uma literatura que "fede", metáfora que demonstra um sujeito-autor que incomoda, não se deixa silenciar e trabalha a equivocidade da língua por meio dos furos que rompem uma ilusória lógica discursiva.

Uma manifestação de furo na língua pôde ser constatada na obra, Quarto de Despejo: diário de uma favelada (2014), quando o poético se instala no discurso literário da escritora, ponto de "respiro" e resistência, em que é possível denunciar o cotidiano infértil da favela, mas também construir "novos mundos", por meio de outros sentidos, em que o céu, as aves, possibilitam outros "cheiros" e cenários para além desse lugar insalubre. É pelo poético que a literatura de enfrentamento social dessa autora, pela via da resistência, possibilita o novo, a surpresa, a polissemia.

Outro ponto que destacamos nas análises foi sobre os sentidos que esse sujeito-autor suscita em sua obra, Diário de Bitita (2016), por meio da materialização da sua escrita de enfrentamento social, não silenciando a questão da escola, em que pudemos constatar a possibilidades de dois movimentos discursos, a saber, o primeiro movimento, o dos sujeitosalunos que se recusam a ir à escola, representação dos "maus sujeitos" (PÊCHEUX, 2009); e o segundo, o dos sujeitos-alunos que, pela prática discursiva manhosa, como modo de sobrevivência, jogam o jogo político dessa instituição.

Além disso, também analisamos uma escrita-indagadora produzida por esse sujeito-autor, desembocadora de uma literatura-filosófica, que "fede", incomoda por causa dos seus questionamentos, produzindo a polissemia rompendo com o "semanticamente estabilizado" (PÊCHEUX, 2009), inclusive, autorizando-se a dizer, mesmo aviltado pelo outro que o desautoriza, no jogo das formações imaginárias, por isso mesmo, enfrentamento social.

Isso porque para ser autor é preciso que o sujeito consiga controlar o sentido do texto, os pontos de fuga, por meio da coesão e coerência (ORLANDI, 1996b), "amarrando" as partes do texto, posicionando-se ao mesmo tempo como autor e leitor do seu texto, trabalhando o interdiscurso no intradiscurso, acessando o arquivo e produzindo sentidos que vão além da paráfrase (PACÍFICO, 2002), no espaço da incompletude da linguagem.

Nesse sentido, consideramos que Carolina Maria de Jesus ocupa a posição de sujeitoautor por conseguir acessar o fio discursivo e tecer uma escrita que leva em consideração essas questões da autoria, porque conforme apontamos, a literatura-cortante (ARRUDA, 2015), da poética de resíduos (FERNANDEZ, 2015) desta escritora, evidencia uma autora 
comprometida com o seus projetos literários.

A partir de todas essas considerações, defendemos que esse movimento discursivo de sujeito-autor perpassa o político, no que designamos de política literária, essa que interdita e/ou legitima um autor e sua obra literária. Esse pêndulo discursivo da política literária é costurado por três pontos nodais: 1 . O conceito que se tem de literatura; 2 . O conceito que se tem de obra clássica, por sua vez, de cânone; 3. O funcionamento do mercado editorial.

Em relação ao primeiro ponto da política literária, consideramos que Carolina Maria de Jesus, na posição de sujeito-autor, permite que a literatura se desloque de um conceito fechado, compartimentado e mumificador, sustentado por uma formação imaginária e ideológica, do que seja literatura de qualidade, desestabilizando conceitos cristalizados e fechados que não consideram as literaturas das bordas e das margens como literaturas de valor. Deste modo, a literatura dessa autora pelo seu não-lugar, produz/reinvindica um espaço na literatura brasileira mostrando que não é mais possível, na contemporaneidade, haver o silenciamento dessas literaturas que se pluralizam cada dia mais, entretanto, não sem contradições.

No segundo ponto, a literatura de Carolina Maria de Jesus nos ajuda a refletir sobre a questão do político no literário, isso porque defendemos a literatura como potência humanizadora de Direito Humano (CANDIDO, 1988). Deste modo, trata-se de um ato político (FREIRE, 2018) porque indica enfrentameto social, em que as literaturas que fogem do conceito de obra clássica e de cânone precisam ser conhecidas e visualizadas, sobretudo, na escola, que precisa admitir que a produção literária de autoria de mulheres negras ainda é ausente nos currículos, bem como que há urgência de levá-la para a sala de aula e suas bibliotecas, a partir de uma pedagogia da diversidade (GOMES, 2017), pautada no discurso polêmico (ORLANDI, 2012), em que a democratização da disputa dos sentidos pode se fazer presente.

Por fim, no terceiro ponto, pudemos observar que Carolina Maria de Jesus, na posição de sujeito-autor, ao produzir sua primeira obra Quarto de despejo: diário de uma favelada (2014), teve grande apoio do mercado editorial, não pelo reconhecimento de sua autoria, mas, sobretudo, devido às altas vendagens que sua obra teve no ano de 1960, superando, inclusive, Jorge Amado e outros escritores consagrados/legitimados.

Deste modo, ao mesmo tempo que o mercado editorial contribui para a legitimação de um autor e sua obra, por outro, a sua preocupação visava apenas ao lucro; portanto, trata-se de 
uma legitimidade frágil e dissimulada, visto que após a publicação da primeira obra de Carolina Maria de Jesus esse mesmo mercado fecharia as portas para as suas outras narratividades.

Na contemporaneidade, como um modo de resistência, é possível observar editoras que não se filiam à ideologia do lucro, ao colocarem no mercado obras de autoras e autores que não são reconhecidos, como é o caso da editora Mjiba que tem publicado obras de autoria de mulheres negras.

Por fim, Carolina Maria de Jesus e suas obras são literatura porque sua "fome" da escrita e também de alimento, levam-nos a considerar seus livros como obras literárias de enfrentamento social, especialmente, pelo fato de não silenciar certas misérias da vida humana e fazer ranger a estrutura de certas instituições das letras que "escondem para debaixo do tapete" essa questão da literatura de autoria de mulheres negras.

As obras de Carolina Maria de Jesus ao serem trabalhadas na escola provocam essa instituição a "arregaçar as mangas" a fim de garantir a literatura de autoria de mulheres negras aos sujeitos-escolares.

Carolina Maria de Jesus ocupa a posição de sujeito-autor com autoria, ou seja, é um sujeito-autor que consegue trabalhar o interdiscurso no intradiscurso, responsabilizando-se pelo seu dizer, trazendo sentidos polissêmicos em uma escrita que denuncia o status quo por meio da resistência pela palavra.

Ao pensar nessa formação imaginária de autor ideal remetemo-nos à Carolina Maria de Jesus, que romperá com esse ideal literário ao autorizar-se a dizer e a ocupar a posição de sujeito-autor, isto é, o que se responsabiliza pelo seu dizer, que encontra na palavra um meio de sobre-viver, de (re)existência e de, sobretudo, produzir sentidos; portanto, uma posição de poder.

Ao tratarmos da importância do conceito de literatura e de obra clássica nos capítulos deste trabalho, objetivamos mostrar o quanto são conceitos moventes e políticos que estão em constante disputa, efeito da política literária.

Discutir o caráter político da literatura é, sobretudo, reconhecê-la como um campo de conhecimento e de direito social, valorizando e legitimando outras geografias literárias, pois não há mais espaço para a interdição das vozes marginalizadas, mesmo porque elas nunca ficaram caladas, embora ainda muitas instituições (escola, centros universitários, feiras literárias etc) continuem dissimulando suas cegueiras. 
Carolina Maria de Jesus, assim como tantas outras mulheres negras desse país, resiste produzindo literaturas de enfrentamento social, provando que a luta do sujeito-negro pelo seu espaço e sua cidadania está sempre (re)començando, pois, conforme disse Carolina, "quem inventou a fome são os que comem".

Figura 4 - Manuscrito de Carolina Maria de Jesus

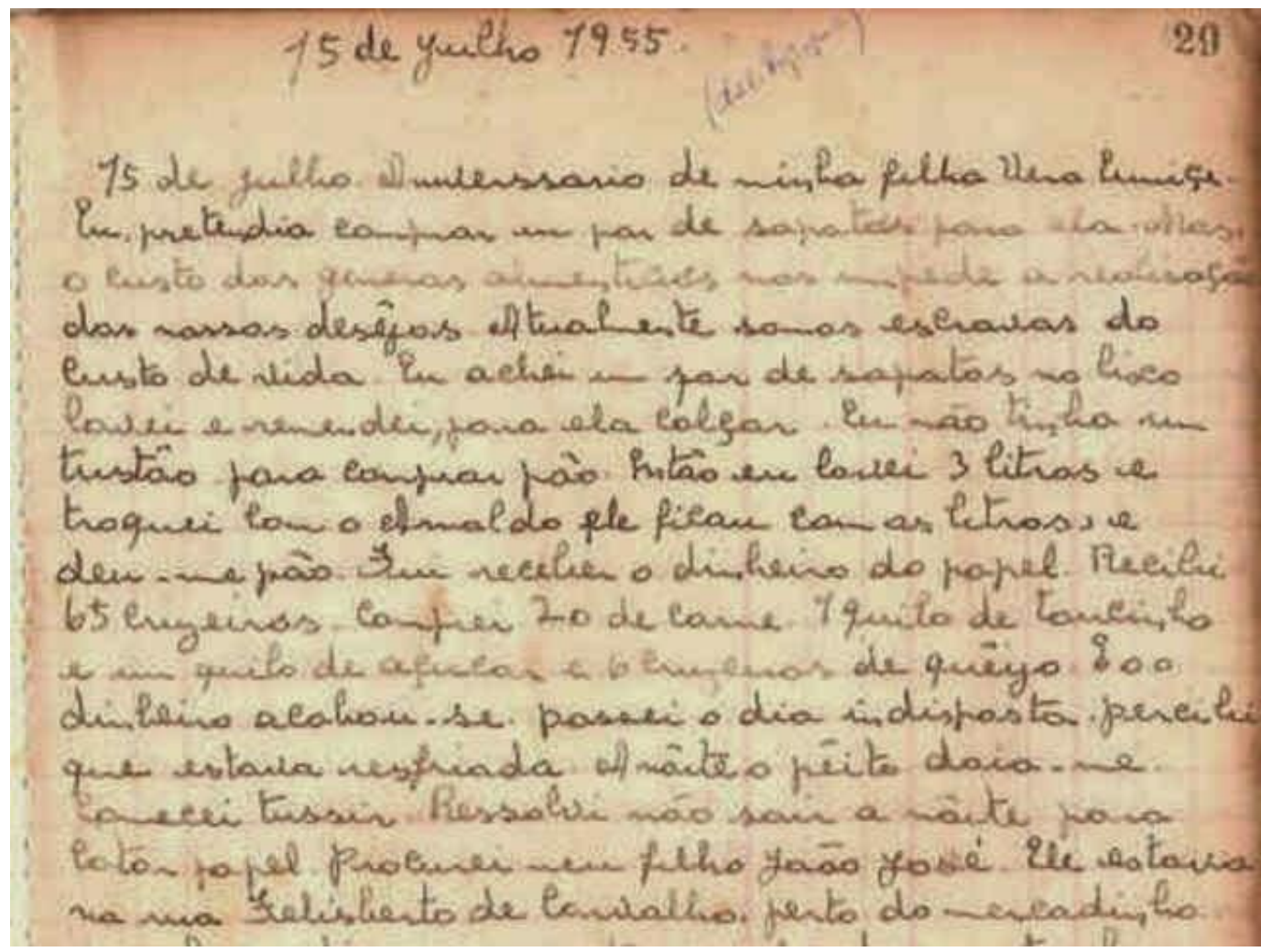

Fonte: FARIAS (2017)

Figura 5 - Google homenageia o centenário de Carolina Maria de Jesus

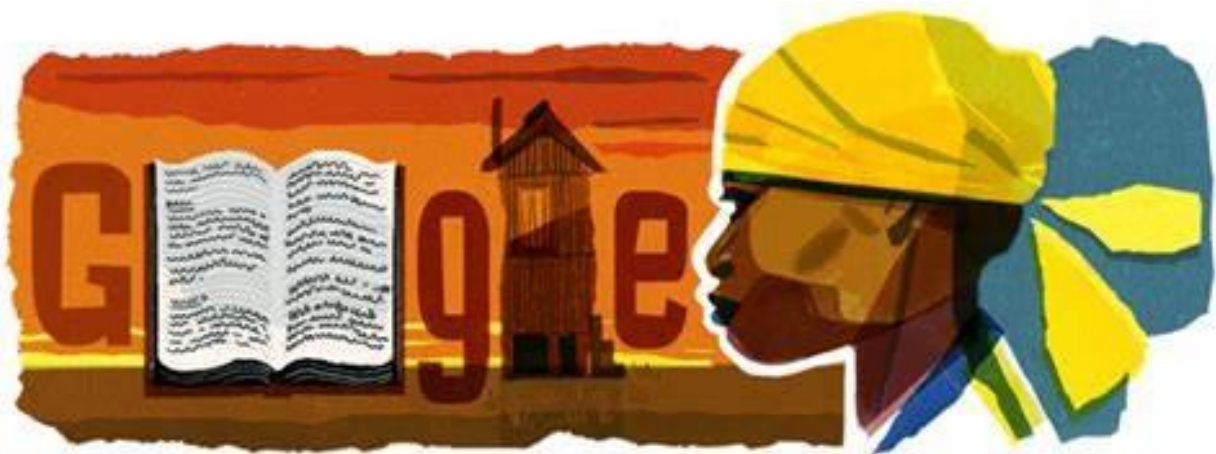

Fonte: ILHÉU, T. (2019)

\footnotetext{
${ }^{8}$ Disponível em: < https://guiadoestudante.abril.com.br/atualidades/google-homenageia-105o-aniversario-de-carolina-maria-
} 


\section{REFERÊNCIAS BIBLIOGRÁFICAS}

ALMEIDA, S. O que é racismo estrutural? Belo Horizonte: Letramento: Justificando, 2019. (Coleção Feminismos Plurais).

ANDRADE, O. Poesias reunidas. In: Obras completas. Rio de Janeiro: Civilização Brasileira, 1978, p. 47.

ANGElUCCI, C. B., KALMUS, J., PAPARELli, R., PATTO, M. H. O estado da arte da pesquisa sobre o fracasso escolar. Educação e Pesquisa, São Paulo, v.30, n.1, jan./abr., 2004.

Antologia Trans. São Paulo: Editora Invisíveis Produções, 2017.

ARAÚJO, Bárbara. Conceição Evaristo: literatura e consciência negra. Entrevista concedida com Blog Blogueiras Feministas, em 30 de set. de 2010. Disponível em: <http://blogueirasfeministas.com/2011/11/conceicao-evaristo/>. Acesso em 13 de nov. de 2018 .

ARROYO, M, G. Currículo, território em disputa. Petrópolis: Vozes, 2012.

ARRUDA, A, A. Carolina Maria de Jesus: projeto literário e edicação crítica de um romance inédito. Tese de Doutorado em Literatura Brasileira. UFMG. Belo Horizonte, MG, 2015 .

ASSIS, M de. Dom Casmurro. São Paulo: Ática, 1974.

Memórias Póstumas de Brás Cubas. São Paulo: Ática, 1997.

BAGNO, M. Preconceito Linguístico: o que é? Como se faz? 49ªed. São Paulo: Loyola, 2007.

Bragatto FILHO, P. Pela Leitura Literária na Escola de $1^{0}$ Grau. São Paulo: Ática, 1995.

BRASIL. Presidência da República. Lei 9.394 de 20 de dezembro de 1996. Estabelece as diretrizes e bases da educação nacional. Disponível em:. Acesso em: 13/11/2018.

Presidência da República. Lei 10.639 de 9 de janeiro de 2003. Altera a Lei 9.394, de 20 de dezembro de 1996, que estabelece as diretrizes e bases da educação nacional, para incluir no currículo oficial da Rede de Ensino a obrigatoriedade da temática "História e Cultura Afro-Brasileira", e dá outras providências. Disponível em: 
Acesso em: 13/11/2018.

- Ministério da Educação/Secretaria de Educação Continuada, Alfabetização e Diversidade. Diretrizes Curriculares Nacionais para a Educação das Relações Étnico- Raciais e para o Ensino de História e Cultura Afro-Brasileira e Africana. Brasília, 2004.

Plano Nacional das Diretrizes Curriculares Nacionais para a Educação das Relações Étnico-Raciais e para o Ensino de História e Cultura AfroBrasileira e Africana. Brasília: SECAD; SEPPIR, 2009. Disponível em: . Acesso em: 13/11/2018.

CALVINO, I. Por que ler os clássicos. Tradução Nilson Moulin. São Paulo: Companhia das Letras, 1993.

CANDIDO, A. O direito à Literatura. In: Vários escritos. São Paulo: Duas Cidades, 1988.

COMPAGNON, A. O demônio da teoria: literatura e senso comum. Tradução de Cleonice Paes Barreto Mourão, Consuelo Fontes Santiago. $2^{\mathrm{a}} \mathrm{ed}$. Belo Horizonte: Editora UFMG, 2010.

CUTI, L, S. Literatura negro-brasileira. São Paulo: Selo Negro, 2010. - (Coleção Consciência em debate/ coordenada por Vera Lúcia Benedito).

DAVIS, A. Mulheres, raça e classe. Tradução de Heci Regina Candiani. São Paulo: Boitempo, 2016.

EAGLETON, T. Teoria da Literatura: Uma introdução. Tradução: Waltensir Dutra; [revisão da tradução: João Azenha Jr]. $6^{\mathrm{a}}$ ed. São Paulo: Martins Fontes, 2006.

EVARISTO, C. Literatura negra: uma poética de nossa afro-brasilidade. Revista SCRIPTA, Belo Horizonte, v. 13, n. 25, p. 17-31, $2^{\circ}$ sem. 2009.

Malê, 2018.

Poemas de recordação e outros movimentos. Rio de Janeiro:

FARIAS, T. Carolina: uma biografia. Rio de Janeiro: Malê, 2017.

FERNANDES, C. A. Análise do discurso: reflexões introdutórias. Goiânia: Trilhas Urbanas, 2005 .

FERNANDEZ, R, A. Processo criativo nos manuscritos do espólio literário de Carolina Maria de Jesus. Tese de Doutorado em Teoria e Crítica Literária. UNICAMP, Campínas, SP, 
2015.

FOUCAULT, M. A arqueologia do saber. Rio de Janeiro: Forense Universitária, 1997.

. A ordem do discurso. São Paulo: Loyola, 2011.

O que é um autor?. In:

Ditos e escritos III: Estética:

literatura e pintura, música e cinema. Tradução de Inês Barbosa. Rio de Janeiro: Forense, 2011.

FRANCO, M. UPP - a redução da favela a três letras: uma análise da política de segurança pública do Estado do Rio de Janeiro. Dissertação de Mestrado em Administração. Universidade Federal Fluminense, 2014.

FREIRE, P. Educação como prática da liberdade. $23^{\text {a }}$ ed. Rio de Janeiro: Paz e Terra, 1999.

Pedagogia da Tolerância. $6^{\text {a }}$ ed. Rio de Janeiro: Paz e Terra, 2018.

Pedagogia do oprimido. Rio de Janeiro: Paz e Terra, 2005.

FREYRE, G. Casa Grande e Senzala. Rio de Janeiro: Record, 1989.

GERALDI, J, W. O texto na sala de aula (org). São Paulo: Anglo, 2012.

GNERRE, M. Linguagem, escrita e poder. 3. ed. São Paulo: Martins Fontes, 2009.

GOMES, N, L. O Movimento Negro educador: saberes construídos nas lutas por emancipação. Petrópolis, RJ: Vozes, 2017.

(Org). Práticas pedagógicas de trabalho com relações étnicoraciais na escola na perspectiva da Lei 10.639/2003. Brasília: MEC, UNESCO, 2012.

GONZALEZ, L. \& HASENBALG, C. Lugar de negro. Rio de Janeiro: Marco Zero, 1981.

HAROCHE, C. Fazer dizer, querer dizer. São Paulo, SP: Editora Hucitec, 1992.

HENGE, G, da S. Texto e interpretação: Aproximações entre Análise do Discurso e Literatura. Revista INTERLETRAS, ISSN No 1807-1597. V. 3, Edição número 20, de Outubro, 2014/Março, 2015. 
HOOKS, B. Ensinando a Transgredir: a educação como prática de liberdade. Tradução de Marcelo Brandão Cipolla. São Paulo: Martins Fontes, 2013.

. Olhares negros: raça e representação. Tradução de Stephanie Borges. São Paulo:

Elefante, 2019.

JESUS, C, M de. Diário de Bitita. São Paulo: Sesi editora, 2016.

Meu estranho diário. São Paulo: Xamã, 1996.

Quarto de despejo: diário de uma favelada. São Paulo: Ática,

2014.

LAJOLO, M. A leitora no quarto dos fundos. Leitura: Teoria e Prática. Campinas: Mercado Aberto, ano 14, n.25, p.10-18, Junho de 1995.

O texto não é pretexto. In: ZILBERMAN, R. (org). Leituras em crise na escola: as alternativas do professor. Porto Alegre - RS: Mercado Aberto, 1991.

LEANDRO, M, L, da C, R. O "corpo estranho" da poesia e a produção de sentidos na escola. Trabalho de Conclusão de Curso. FFCLRP-USP, Ribeirão Preto, SP, 2016.

LEJEUNE, P. O pacto autobiográfico. De Rousseau a internet. Belo Horizonte: Ed. UFMG, 2008.

LEVINE, R. M. \& MEIHY J. C. S. B. The life and death of Carolina Maria de Jesus. Albuquerque: University of New Mexico Press, 1995.

UFRJ, 1994

Cinderela negra: a saga de Carolina Maria de Jesus. Rio de Janeiro, RJ: Editora

LIEBIG, S, M. Dossiê black \& branco: literatura, racismo e opressão nos Estados Unidos e no Brasil. João Pessoa, PB: Ideia, 2003.

LISPECTOR, C. A Hora da Estrela. Rio de Janeiro: Rocco, 1998.

LLOSA, M, V. A civilização do espetáculo: Uma radiografia do nosso tempo e da nossa cultura. Tradução de Ivone Benedetti. Rio de Janeiro: Objetiva, 2013.

LORDE, A, Race, Class and Sex: Women Redefining Difference. Sister Outsider. Essays and Speeches. Freedom: Crossing Press, 1984. 
MIRANDA, F, R de. Os caminhos literários de Carolina Maria de Jesus: experiência marginal e construção estética. Dissertação em Letras. FFLCH-USP, 2013.

MOSÉ, V. A escola e os desafios contemporâneos. Rio de Janeiro: Civilização Brasileira, 2013.

MOURA, C. Sociologia do negro brasileiro. São Paulo: Ática, 1988.

MUNANGA, K. Consideraçãoes sobre as políticas de ação afirmativa no ensino superior. In: PACHECO, J, Q; SILVA, M, N. (Orgs.). O negro na universidade: o direito a inclusão. Brasília, DF: Fundação Cultural Palmares, 2007.

MUNANGA, K, e GOMES, N, L. Para entender o negro no Brasil de hoje: história, realidades, problemas e caminhos. São Paulo: Global; Ação Educativa, 2016.

MUSSALIM, F. Análise do Discurso. In: MUSSALIM, Fernanda e BENTES, Anna Christina (org). $4^{\text {a }}$ ed. Introdução à Linguística: Domínios e Fronteiras. São Paulo: Cortez, 2004.

NASCIMENTO, A. O genocídio do negro brasileiro: processo de um racismo mascarado.

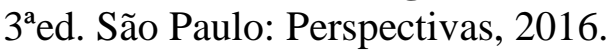

NIETZSCHE, F. Assim Falou Zaratustra. Tradução: Paulo César de Souza. São Paulo: Companhia das Letras, 2011.

ORLANDI, E, P. À flor da pele: indivíduo e sociedade. In: MARIANI, B. (Org). A escrita e os escritos: reflexões em análise do discurso e psicanálise. São Carlos: Claraluz, 2006.

Campinas, SP: Pontes, 1996a.

A linguagem e seu funcionamento: as formas do discurso. 4. ed. . As formas do silêncio: nos movimentos dos sentidos. Campinas, SP: Editora Unicamp, 1997.

Análise de discurso: princípios e procedimentos. 6. ed. Campinas,

SP: Pontes, 2001.

; Eu Tu Ele: discurso e real da história. 2. Ed. Campinas, SP: Pontes, 2017.

Editora da Unicamp, 2012.

Discurso e leitura. 9. ed. São Paulo: Cortez; Campinas, SP: 
Petrópolis-RJ: Vozes, 1996b.

Interpretação; autoria, leitura e efeitos do trabalho simbólico.

Ser diferente é ser diferente: a quem serve a noção de minorias? in Linguagem, Sociedade, Políticas, Eni P. Orlandi (org.). Univás: RG, 2013.

PACÍFICO, S. M. R. Argumentação e autoria: o silenciamento do dizer. Tese de Doutorado em Ciências. FFCLRP-USP, Ribeirão Preto, SP, 2002.

PACÍFICO, S, M, R. Argumentação e autoria nas redações de universitários: Discurso e silêncio. Curitiba: Appris, 2012.

As posições de autor e leitor no jogo discursivo. In: TFOUNI, Leda

Verdiani. Múltiplas faces da autoria. Ijuí-RS: Unijuí, 2008, p. 237-254.

Leitura, escrita e autoria nas séries iniciais do Ensino Fundamental. FAPESP- No. 2010/15782-6.

O direito à argumentação no contexto escolar. In: PIRIS, E, L;

FERREIRA, M, O. (org). Discurso e argumentação: em múltiplos enfoques. Grácio Editor, 2016.

Carlos: Pedro \& João Editores, 2013.

LEANDRO, M; L; C; R.; MATIAS, A; P. Ter ou não ter: a construção de sentidos de liberdade no espaço escolar. In: SOUSA, L; M; A. ET all. Travessias em discurso: a língua na história. São Carlos: SP: Pedro \& João Editores, 2017, p. 85- 99; 119-139.

PATTO, M, H, S. A Família Pobre e a Escola Pública: Anotações Sobre Um Desencontro. Psicologia - USP, São Paulo, v.3, n.1/2, p. 107 - 121, 1992.

A Produção do Fracasso Escolar: histórias de submissão e rebeldia. São Paulo: TA Queiroz, Reimpressão, 1996.

PAYER, P, M. O. Linguagem e sociedade contemporânea: sujeito, mídia, mercado. Revista RUA, 11, 9-25, 2005.

PÊCHEUX, M. (1969). Análise Automática do Discurso. In: GADET, F.; HAK, T. (Orgs.). Por uma análise automática do discurso: uma introdução à obra de Michel Pêcheux. Trad.

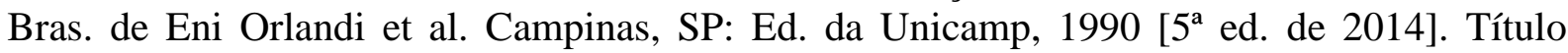


original: Analyse automatique du discours (Paris, Dunod, 1969, 142 p.).

Análise de Discurso: Michel Pêcheux. Tetxos escolhidos por Eni Orlandi. Campinas: Pontes, 2015.

Análise do Discurso: três épocas (1983). In: GADET F.; HAK, T. (Orgs.) Por uma Análise Automática do Discurso: uma introdução à obra de Michel Pêcheux. Trad. de Eni P. Orlandi. Campinas: Unicamp, 2014.

GADET, F. La langue introuvable. Paris: Maspéro, 1981. Versão brasileira: A língua inatingível: o discurso na história da linguística. Trad. de Bethania Mariani e Maria Elizabeth

C. de Mello. Campinas, SP: Pontes, 2004.

Ler o arquivo hoje In: ORLANDI, E. P. (Org) [et al] Gestos de leitura: da História no Discurso. Campinas-SP: Editora da UNICAMP, 2010.

O discurso: estrutura ou acontecimento. Trad. Bras. de Eni P. Orlandi. Campinas, SP: Pontes, 1990 [6 $6^{\mathrm{a}}$ ed. de 2012]. Título original: "Discourse: Structure or Event?" (1983) In: NELSON, C.; GROSSBERG, L. (Eds.). Marxism and the Interpretation of Culture. Urbana; Chicago: University of Illinois Press, 1988. pp. 633-650.

Semântica e Discurso: uma crítica à afirmação do óbvio. Trad. Bras. de Eni P. Orlandi et al. Campinas: Ed. da Unicamp, 1988 [4 $4^{\mathrm{a}}$ ed. de 2009]. Título original: Les vérités de la Palice (Paris, Maspero, 1975).

PFEIFFER, C, R, C. Que autor é este?. Dissertação de mestrado em Linguística Universidade Estadual de Campinas, Campinas, SP, 1995.

PROENÇA FILHO, D. A trajetória do negro na literatura brasileira. In: PEREIRA, E de A. (Org). Um tigre na floresta dos signos: Estudos sobre poesia e demandas sociais no Brasil. Belo Horizonte: Mazza Edições, 2010. (Coleção Setefalas).

REIS, M, F, dos. Úrsula. Florianópolis: Editoras Mulheres; Belo Horizonte: PUC Minas, 2014.

REYS, A. Vozes dos porões: A literatura periferia/marginal do Brasil. Rio de Janeiro: Aeroplano, 2013.

RIBEIRO, A, P. Argumentação e(m) Discurso Pedagógico: espaço de confronto, silêncio e autoria. Dissertação de Mestrado em Educação. FFCLRP-USP, Ribeirão Preto, SP, 2017. 
RIBEIRO, P, T. Fracasso escolar: reflexões sobre um problema que se repõe e possibilidades de enfrentamento. Dissertação de Mestrado em Educação. Universidade Metodista de Piracicaba, 2013.

RIBEIRO, D. O que é lugar de fala. Belo Horizonte: Letramento: Justificando, 2017. (Coleção Feminismos Plurais).

RODRIGUES, A. Escrita e Autoria: entre histórias, memórias e descobertas. Campinas-SP: Mercado das Letras, 2011.

RODRIGUES, Valter. Menina salva livros de enchente em Pernambuco e foto comove a web. 2017. Disponível em: <https://noticias.uol.com.br/cotidiano/ultimasnoticias/2017/06/01/menina-salva-livros-de-enchente-em-pernambuco-e-foto-comove-aweb.htm>. Acesso em: 22 out. 2018.

ROMÃO, L, M, S; PACÍfICO, S, M, R. Efeitos de leitura: sujeitos e sentidos em movimento. Ribeirão Preto - SP: Alphabeto, 2010.

. .; PACÍFICO, S. M. R. Era uma vez uma outra história: leitura e interpretação na sala de aula. São Paulo: DCL, 2006.

. ; PACÍFICO, S, M, R. Leituras em discurso: a literatura infantil na sala de aula. Ribeirão Preto - SP: Alphabeto, 2010.

RUFFATO, L. Questão de pele. (Org). Rio de Janeiro: Língua Geral, 2009.

SAINT-EXUPÉRY. O pequeno príncipe. 44ªed. Rio de Janeiro: Editora Agir, 1997.

SAUSSURE, F de. Curso de linguística geral. [trad. Antônio Chelini, José Paulo Paes e Izidoro Blikstein] 20ª ed. São Paulo: Cultrix, 1995.

SCHWARCZ, L, M. O Espetáculo das Raças: cientistas, instituições e questão racial no Brasil de 1870-1930. São Paulo: Companhia das Letras, 1993.

SANTOS, B, S. Para além do pensamento abissal: das linhas globais a uma ecologia dos saberes. In: SANTOS, B, S. \& MENESES, M, P. (Orgs). Epistemologias do Sul. Coimbra: Almedina/CES, 2009, p.23-71.

. Do pós-moderno ao pós-coloinial - e para além de um outro. Coimbra, 2004a.

. Por uma sociologia das ausências e uma sociologia das emergências. In: SANTOS, B, S. (Org.). Conhecimento prudente para uma vida decente. São Paulo: Cortez, 2004b, p. 
$777-821$.

Por uma pedagogia do conflito. In: SILVA, L, H. Et al. (Orgs). Novos mapas culturais, novas perspectivas educacionais. Porto Alegre: Sulina, 1996, p.15 -33.

SILVA, E da S. (Des) caminhos da escola: traumatismos educacionais. São Paulo: Cortez, 2011.

SILVA, V, M, T. Leitura Literária e Outras Leituras: impasses e alternativas no trabalho do professor. Belo Horizonte: RHJ, 2009.

SOUZA, Neusa Santos. Tornar-se negro. Rio de Janeiro: Graal,1983.

TFOUNI, L. V. Letramento e Alfabetização. 9. ed. - São Paulo: Cortez, 1995.

Múltiplas faces da autoria. Ijuí: Ed. Unijuí, 2012.

TIZIOTO, P. A.; PACÍFICO, S. M. R.; ROMÃO, L. M. S. Leitura e interpretação: percursos que engendram a escrita infantil. Revista Leitura. Teoria \& Prática. ALB. Ano 27, $\mathrm{n}^{\circ} 53$, p.61-70, nov.2009.

TODOROV, T. Nós e os outros - a reflexão francesa sobre a diversidade humana. Rio de Janeiro: Jorge Zahar, 1993.

WAISELFISZ, J, J. Mapa da violência: homicídio de mulheres no Brasil. Rio de Janeiro: Flasco, 2015. 